UNIVERSIDADE DE SÃO PAULO

PROGRAMA INTERUNIDADES EM ESTÉTICA E HISTÓRIA DA ARTE

GABRIELA BORGES ABRAÇOS

APROXIMAÇÕES ENTRE MARIO PEDROSA E GESTALT

CRÍTICA E ESTÉTICA DA FORMA

São Paulo 
GABRIELA BORGES ABRAÇOS

\section{APROXIMAÇÕES ENTRE MARIO PEDROSA E GESTALT CRÍTICA E ESTÉTICA DA FORMA}

\footnotetext{
Dissertação apresentada ao Programa de Pós-Graduação Interunidades em Estética e História da Arte da Universidade de São Paulo para obtenção do título de mestre

Orientação: Prof ${ }^{a}$ Dra. Lisbeth Rebollo Gonçalves
}

São Paulo 
AUTORIZO A REPRODUÇÃO E DIVULGAÇÃO TOTAL E PARCIAL DESTE TRABALHO, POR QUALQUER MEIO CONVENCIONAL OU ELETRÔNICO, PARA FINS DE ESTUDO E PESQUISA, DESDE QUE CITADA A FONTE.

Catalogação da Publicação

Biblioteca Lourival Gomes Machado

Museu de Arte Contemporânea da Universidade de São Paulo

Abraços, Gabriela Borges.

Aproximações entre Mário Pedrosa e gestalt : crítica e estética da forma ; orientadora Lisbeth Ruth Rebollo Gonçalves. -- São Paulo, 2012. 199 f. : il.

Dissertação (Mestrado - Programa de Pós-Graduação Interunidades em Estética e História da Arte) -- Universidade de São Paulo, 2012.

1. Crítica de Arte-Brasil - Século 20. 2. Estética (Arte). 3. Psicologia da Gestalt. 4. Abstracionismo - Século 20 . 5. Pedrosa, Mario, 19001981. I. Gonçalves, Lisbeth Ruth Rebollo. II. Título. 


\title{
APROXIMAÇÕES ENTRE MARIO PEDROSA E GESTALT CRÍTICA E ESTÉTICA DA FORMA
}

\author{
Dissertação apresentada ao Programa de Pós-Graduação Interunidades \\ em Estética e História da Arte da Universidade de São Paulo para \\ obtenção do título de mestre \\ Orientação: Prof ${ }^{a}$ Dra. Lisbeth Rebollo Gonçalves
}

Área de concentração: teoria e crítica das artes

Data de Defesa:

Resultado:

Banca Examinadora:

Prof ${ }^{a}$ Dra

Universidade de São Paulo

Prof ${ }^{\mathrm{a}}$ Dra

Instituição:

Prof $^{0}$ Dr.

Instituição:- 


\section{DEDICATÓRIA}

À MINHA MÃE CELINA, INCANSÁVEL APOIADORA E EXEMPLO DE VIDA

À MINHA IRMÃ DANIELA, COMPANHEIRA DE AVENTURAS, ALEGRIAS E SONHOS 


\section{AGRADECIMENTOS}

Em certa feita disse Guimarães Rosa que mestre não é quem ensina, mas quem de repente aprende. No entanto, um percurso de aprendizagem não se constitui sozinho, mas na interlocução com muitas vozes, que foram agregadas à experiência através de aulas, leituras, conversas e vivências. Sendo assim, gostaria de assinalar que se encontram condensados, neste trabalho, os ecos de muitas vozes que se fizeram fundamentais para a realização do mesmo. Sendo assim, ao concluir esta dissertação, gostaria de estender meus sinceros agradecimentos a todas as pessoas que contribuíram para que este trabalho se tornasse realidade.

À DEUS, criador e mantenedor de toda a vida, por ter despertado em mim o sonho deste projeto e pela direção para que este se fizesse possível.

À minha família por todo apoio e aspirações de sucesso. Especialmente à minha mãe Celina por não medir esforços para investir em minha carreira escolar e acadêmica. Pelo apoio incondicional aos meus sonhos e projetos, pela compreensão e amparo nos momentos de inquietações e angústias e pela vibração nas vitórias.

À minha irmã Daniela pelo companheirismo diário, pela torcida e pela paciência em ter nossos passeios procrastinados por minha ausência ao estar dedicada aos estudos e pesquisas.

À minha estimada mestre e orientadora $\operatorname{Prof}^{a} \operatorname{Dr}^{\mathrm{a}}$ Lisbeth Rebollo Gonçalves pelo acolhimento de meu trabalho desde a iniciação científica e que se encaminhou para este trabalho de mestrado. Agradeço pelo privilégio de seu acompanhamento, pela paciência em lidar com minhas dúvidas e inquietações e por compartilhar seus exímios conhecimentos e experiências intelectuais. Agradeço pela oportunidade de participar de diversas atividades acadêmicas que tantos conhecimentos e experiências me agregaram.

À Fundação de Amparo à Pesquisa do Estado de São Paulo pelo apoio financeiro que possibilitou condições ideais para realização desta pesquisa.

À $\operatorname{Prof}^{a}$ Dr $^{\mathbf{a}}$ Daisy Peccinini pelas orientações acadêmicas e por compartilhar seus brilhantes conhecimentos. Agradeço por receber-me gentilmente em sua casa e por dividir sua experiência de ter conhecido e trabalhado com Mário Pedrosa, de modo a afirmar com segurança e autoridade conhecimentos sobre o crítico.

À Prof ${ }^{a}$ Dr $^{a}$ Cláudia Fazzolari pela amizade fraterna, pela sugestão de leituras e pelo acompanhamento nas atividades acadêmicas. 
Ao Prof ${ }^{o}$ Dr. João Gomes Filho pela gentileza em receber-me para uma conversa sobre a gestalt do objeto.

Ao Prof ${ }^{\mathrm{o}}$ Dr. Francisco Alambert pelo acolhimento em suas disciplinas desde o período de graduação na Faculdade de Filosofia, Letras e Ciências Humanas, pela oportunidade de compartilhar de sua erudição. Menciono em especial, sua participação em meu exame de qualificação que me proporcionou orientações lúcidas, críticas e sugestões necessárias para o bom andamento e concretização deste trabalho.

Aos Professores do Programa Interunidades em Estética e História da Arte que com sua competência e brilhantismo intelectual marcaram minha formação acadêmica com ricas experiências e formulações teóricas.

À Sara Vieira Valbon secretaria do Museu de Arte Contemporânea da Universidade de São Paulo por seu apoio institucional nesta caminhada acadêmica. Por sua simpatia e amizade.

À Sylvia Werneck e Gustavo Dionísio por interlocuções sobre o trabalho.

Ao Programa Interunidades em Estética e História da Arte nas pessoas de Aguida Mantegna, Paulo Marquezini e Joana D'Arc Figueiredo pelo atendimento e orientações às questões acadêmicas e burocráticas.

Aos meus amigos e colegas de cursos do Programa de Pós-graduação do Programa Interunidades em Estética e História da Arte, por dividir experiências e conhecimentos. Agradeço à Araceli Barros pela companhia nos anos de graduação, em pesquisas e viagens, somando uma convivência acadêmica e fraterna de dez anos. Também às amigas, Isa Bandeira e Helena Queiroz pela companhia em viagens de pesquisas e Congressos e pelos diálogos sobre as inquietações acadêmicas que tanta experiência me somou. Assinalo ainda a amiga Renata Rocco e o amigo da faculdade de História Rafael Pessolato, pelas conversas sinceras e acolhedoras, onde pudemos trocar impressões, angústias e conquistas acadêmicas.

Somam-se a estes nomes, muitos outros amigos e familiares que torceram por esta realização, mas que, no entanto, estas páginas não seriam suficientes para enumerá-los. Assim, estendo o meu muito obrigado a todos os que colaboraram direta ou indiretamente para que este trabalho se tornasse uma realidade.

À todos sou muito grata! 
"É preciso comportar-se diante de uma obra-prima como diante de um príncipe; não falar primeiro, mas esperar que ela nos interpele. Do contrário não ouviríamos senão a nós mesmos" Schopenhauer 


\section{RESUMO}

A dissertação visa alçar uma reflexão sobre a produção e contribuição crítica de Mário Pedrosa para a arte brasileira, como também identificar alguns de seus paradigmas artísticos que colaboraram para a consolidação de um arcabouço teórico para História da Arte Moderna, tanto no plano nacional, quanto internacional. Objetiva-se delinear a relação entre o que Pedrosa absorveu sobre as teorias gestálticas e exemplos de como ele as aplicou na tessitura de seu discurso crítico. Ao sedimentar o foco de análise no envolvimento do crítico brasileiro com o tema da psicologia da forma, propõe-se ressaltar as implicações estéticas de seu estudo pioneiro Da natureza Afetiva da Forma na Obra de Arte. Pretende-se, ainda, identificar a intersecção entre a psicologia da forma e a crítica de arte de Mário Pedrosa, propondo a influência destas teorias nos textos sobre a obra do artista americano Alexander Calder, artista considerado pelo crítico, como o emblema da estética abstrata construtiva. Busca-se verificar como as teses da psicologia da forma ofereceram ao crítico, subsídios conceituais para uma nova relação com as premissas constitutivas e cognitivas da estética abstrata.

Palavras-chave: Crítica de Arte / gestalt/percepção/ abstração 


\begin{abstract}
The thesis aims at reflecting on the critical production and contribution of Mário Pedrosa to Brazilian art, as well as identifying some artistic paradigms, which contributed to the consolidation of a theoretical framework for the History of Modern Art, both at the national and international levels. The purpose here is to outline the relationship between what Pedrosa absorbed about Gestalt-based theories and examples of how he applied them in constructing his critical discourse. By focusing the analysis on the Brazilian critic's engagement in the subject of the psychology of forms we propose to emphasize the aesthetic implications of his groundbreaking study Da natureza Afetiva da Forma na Obra de Arte (On the affective nature of forms in the work of art). We also intend to identify the intersection between the psychology of forms and Mario Pedrosa's art criticism, pointing the influence of these theories on texts about American artist Alexander Calder, considered by the critic the symbol of constructive abstract aesthetics. We sought to verify how psychology theses on forms offered the critic conceptual material for a new relationship with the constitutive and cognitive premises of abstract aesthetics.
\end{abstract}

Keywords: Art Criticism / gestalt/ perception / abstraction 


\section{LISTA DE ILUSTRAÇÕES}

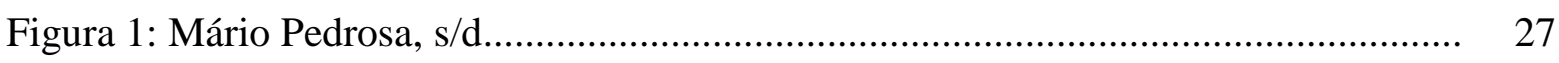

Figura 2: Wassily Kandinsky, Composição IV, 1911_.................................................... 42

Figura 3: Wassily Kandinsky, Composição VIII, 1923........................... 43

Figura 4: Piet Mondrian, Pommier en fleur, 1912.............................. 45

Figura 5: Piet Mondrian, Composição A, 1923............................................................... 47

Figura 6: Registro de Mário Pedrosa, (perfil e frente) quando dada sua entrada como fichado pelo D.E.O.P.S. - Prontuário n 2.030- /27-08-1932.

Figura 7: Documento com o comunicado de prisão de Mário Pedrosa por suas atividades comunistas, entendidas então como subversivas à ordem. Prontuário $\mathrm{n}^{\circ}$

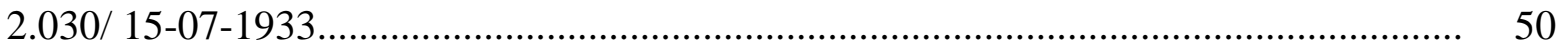

Figura 8: Kaethe Kollwitz, A Revolta dos Tecelões, 1897............................................. 54

Figura 9: Kaethe Kollwitz, As Mães, 1922/23 ......................................................... 55

Figura 10: Mário Pedrosa e seu olhar nas esculturas da Bienal s/d................................ 72

Figura 11: Calder walking with 21 feuilles blanches, Paris, 1953................ 119

Figura 12: Alexander Calder, Two Spheres Within a Sphere, 1931............................... 130

Figura 13: Alexander Calder, Besta Negra [maquete], 1939........................................ 136

Figura 14: Alexander Calder, Armadilha de lagosta e rabo de peixe, 1939..................... 138

Figura 15: Alexander Calder, The Spider, 1940 .................................. 145 


\section{SUMÁRIO}

INTRODUÇÃO......................................................................................................... 13

1. PANORAMA DAS IDEIAS DE MÁRIO PEDROSA............................................. 27

1.1 MÁRIO PEDROSA E A CRÍTICA DA ARTE MODERNA NO BRASIL: PRIMEIROS MOMENTOS............................................................................ 28

1.2 PERCURSO E FORMAÇÃO DE SEU PENSAMENTO............................................. 30

1.3 A BERLIM DOS ANOS 1920........................................................................ 31

1.4 A ALEMANHA DE WEIMAR ..................................................................... 34

1.5 AS INFLUÊNCIAS TEÓRICAS E AS PESQUISAS ESTÉTICAS: OS

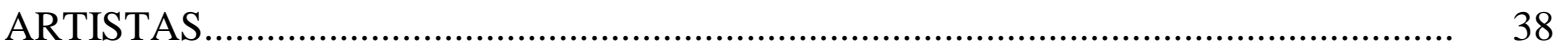

1.5.1 Kandinsky: Entre a razão e a emoção...................................................................... 40

1.5.2 Mondrian: $\mathbf{O}$ construtivismo racional..................................................................... 44

1.6 A DÉCADA DE 1930: A CONJUGAÇÃO ENTRE POLÍTICA E ARTE................. 48

1.7 NOVA YORK: RETOMADA DE PESQUISAS................................................... 57

1.8 A ARTE ABSTRATA- PANORAMA DAS IDÉIAS................................................ 59

1.9 O ENVOLVIMENTO DE PEDROSA COM A ARTE ABSTRATA......................... 62

1.10 UM CONTRAPONTO DA ESTÉTICA ABSTRATA: O EXPRESSIONISMO ABSTRATO DE CLEMENT GREENBERG............................................................. 66

1.11 UMA INTERSECÇÃO DAS IDÉIAS: OS CRÍTICOS E SUAS CRÍTICAS........... 70

2 AS APROXIMAÇÕES DE MÁRIO PEDROSA ÀS TEORIAS DA

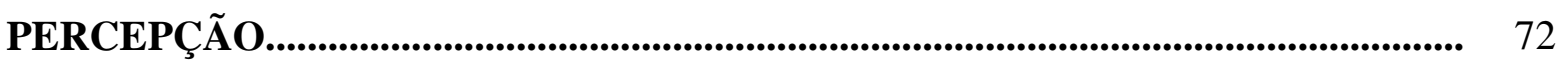

2.1 UMA APROXIMAÇÃO ÀS TEORIAS SOBRE FORMA E PERCEPÇÃO NA TESE "DA NATUREZA AFETIVA DA FORMA NA OBRA DE ARTE”: IDÉIAS GERAIS.

2.2 DO INTERESSE PELO TEMA.........................................................................

2.3 OS PRESSUPOSTOS TEÓRICOS................................................................. 76

2.4 A PSICOLOGIA DA FORMA VISTA POR MÁRIO PEDROSA: TEMAS INERENTES À OBRA DE ARTE........................................................................... 80

2.4.1 Reverberações Teóricas........................................................................................... 80

2.4.2 As designações gestálticas na tese de Pedrosa........................................................... 84 
2.4.3 O modelo gestáltico e a atribuição do significado.............................................. 90

2.4.4 As atribuições da Forma e a Expressão artística.............................................. 95

2.5 AS REPERCUSSÕES DA APRESENTAÇÃO DA TESE DE MÁRIO PEDROSA:

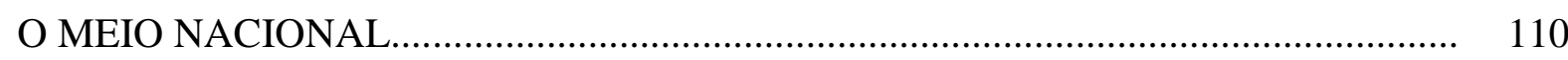

2.6 A REPERCUSSÃO INTERNACIONAL DA TESE DE MÁRIO PEDROSA.......... 114

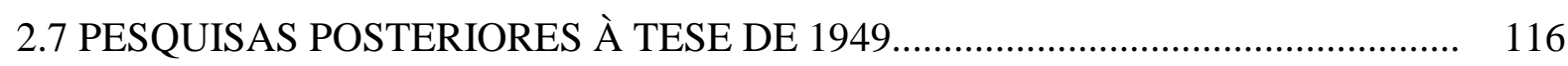

3 O ENTROSAMENTO COM A OBRA DE ALEXANDER CALDER: APROXIMAÇÕES ENTRE TESES GESTÁLTICAS E CRÍTICA DE ARTE........ 119

3.1 INTERSECÇÃO DA PSICOLOGIA DA FORMA E A CRÍTICA DE ARTE DE

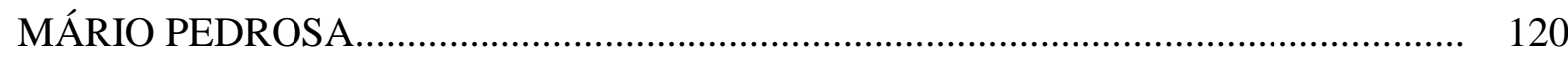

3.2. LEITURAS DE CALDER POR PEDROSA: PERCURSO DO ARTISTA RUMO

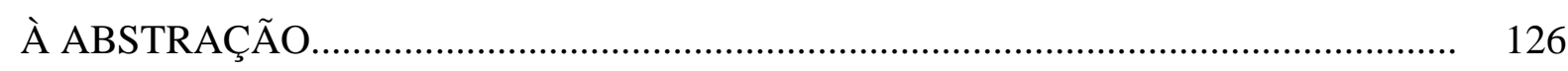

3.3 EXERCÍCIO CRÍTICO DE PEDROSA: OS ESTÁBILES E MÓBILES DE

CALDER E A PERCEPÇÃO DA FORMA............................................................... 133

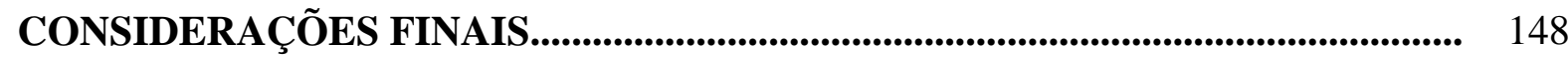

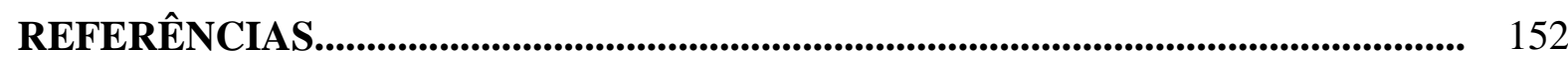

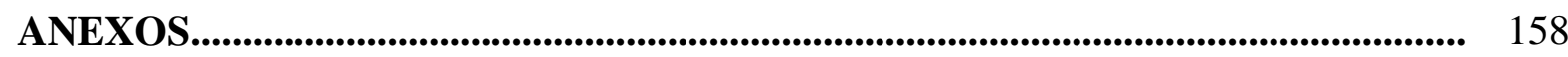




\section{INTRODUÇÃO}

\section{O PERCURSO DO CRÍTICO}

No18 Brumário de Louis Bonaparte publicado em 1852, Karl Marx escreveu "Os homens fazem a sua própria história, mas não a fazem como querem; não a fazem sob circunstâncias de sua escolha e sim sob aquelas com que se defrontam diretamente, legadas e transmitidas pelo passado" 1. Esta afirmação muito claramente se aplica ao percurso intelectual de Mário Pedrosa, pois fora um humanista, trotskista engajado com o debate político e crítico de arte que percorreu a vida dedicando-se à concretização de seus preceitos e convicções, preceitos estes ligados a uma atualização intelectual constante e um interesse e engajamento com o ideário libertário. No entanto, como na assertiva de Marx, a realidade histórica vivida por Pedrosa, muitas vezes, não lhe fora simpática e por diversas ocasiões mostrou-se hostil e ameaçadora. Por mais de uma vez o crítico teve que se manter em exílios, ou com seu paradeiro ocultado por amigos, devido sua militância trotskista. Mário Pedrosa, porém, nunca se extenuou diante de seus fracassos, imiscuindo-se por convicções utópicas que sempre demonstraram a vitalidade e intenções programáticas de suas atitudes políticas e críticas.

Mário Pedrosa viveu e transitou pelo longo² século XX - 1900-1981- e acompanhou intensamente os principais eventos da realidade histórica mundial. As experiências acadêmicas, militantes e artísticas que teve oportunidade de vivenciar, lhe proporcionaram a constituição de um cabedal erudito e diversificado. A fundamentação teórica do pensamento político e estético de Pedrosa partiu de uma formação precipuamente arregimentada no marxismo clássico, e a partir deste, envolveu-se e interessou-se pelas teorias sociais e científicas que estiveram ao seu alcance. Em seu percurso esteve a transitar por diversos

\footnotetext{
${ }^{1}$ MARX, Karl. O 18 Brumário de Louis Bonaparte. São Paulo, Boitempo Editorial, 2011. Esta citação de Marx elucida a fragilidade das ações humanas diante de sua historicidade.

${ }^{2}$ Referência à obra A era dos Extremos: o Breve século XX (1914-1991), livro escrito pelo historiador de nacionalidade britânica, Eric Hobsbawm e que apresenta-nos um panorama histórico das convulsões políticas do século XX, que segundo a sua designação cronológica iniciou-se com a primeira guerra mundial e terminou com a desintegração da União Soviética. O historiador ainda assimila estes acontecimentos, como um testemunho de fatos históricos que coincidiram com sua vida. Igualmente ao testemunho de Eric Hobsbawm, a vida de Mário Pedrosa apresenta-se como um panorama relacionado aos principais eventos políticos e artísticos do século XX. $\mathrm{O}$ crítico brasileiro manteve-se informado e, de certa forma relacionado, aos principais acontecimentos do cenário artístico e das manifestações de esquerda dos anos novecentos, passando pelo comunismo, trotskismo e pelas Internacionais comunistas.
} 
contextos históricos e políticos marcantes do século XX. Nos anos em que esteve na Alemanha assistiu à ascenção do nazismo na década de 1920, como também, mobilizou-se nas fileiras da esquerda contra os extremismos que os governos da direita articulavam. Em solo brasileiro testemunhou os excessos das ditaduras varguista e militar, durante as décadas de 1930 e posteriormente em 1960. Vibrou com as expectativas da modernização brasileira na década de 1950 e empenhou-se pela modernização daqueles que viriam a constituir-se como os principais aparatos culturais do país, quando trabalhou ativamente no Museu de Arte Moderna de São Paulo e na Bienal de São Paulo. Entre diversos outros projetos críticos, curatoriais, além manter-se envolvido com movimentos artísticos, Pedrosa sempre se entusiasmou com as medidas que colaborassem para o crescimento e divulgação das instituições culturais, sem, contudo, vulgarizá-las.

Em suas realizações críticas, estéticas e políticas conheceu um espectro diversificado de ciências. Articulou-se com proficiência entre as teorias políticas e sedimentou suas ideias no trotskismo. Ao lado deste, transitou pelas teorias emergentes, pelos domínios da sociologia, filosofia, psicologia e psicanálise, gestalt e fenomenologia. Construiu elaborações estéticas associadas às analises filosóficas, econômicas, antropológicas, matemáticas além de consistente conhecimento na teoria e História da Arte. Nutriu um fascínio pela tecnologia da máquina e sem nunca perder o horizonte da Revolução Permanente. Esta premissa trotskista, fez com que Mário Pedrosa atribuísse à arte um papel fundamental de formação e transformação do indivíduo a fim de prepará-lo para uma nova sensibilidade e desenvolvê-lo para a percepção de uma outra constituição social, consciente de sua historicidade e das possibilidades de um contexto político-social que fosse libertário e democrático.

Mário Pedrosa foi um importante crítico que atuou neste contexto, e deu à crítica de arte brasileira contribuição com sólida base de conhecimento científico. Como crítico, professor, diretor de museu, membro de júris de grandes exposições de arte, e como espectador, encontrava na arte a potencialidade de decodificar as tensões do mundo, capaz de influenciar a sensibilidade e percepções humanas, a fim de colaborar para uma sociedade mais esclarecida e sensível às diversas formas de expressão. Crítico e historiador da arte, Pedrosa foi um dos fundadores, em 1949-50, da Associação Internacional de Críticos de Arte- AICA. Presidiu a Associação Brasileira de Críticos de Arte de 1963 a 1969; foi diretor do Museu de Arte Moderna de São Paulo, lecionou História e Estética na Faculdade Nacional de Arquitetura e no Colégio Pedro II no Rio de Janeiro, e atuou como crítico de arte em vários jornais brasileiros: Diário da Noite (SP), Correio da Manhã (RJ), Jornal do Brasil (RJ), entre 
outros, além de participar da organização da Fundação Bienal de São Paulo e compor diversos júris, no Brasil e no mundo.

Mário Pedrosa iniciou-se na atividade crítica na década de 1930 com uma conferência sobre a arte social da gravurista Kaethe Kollwitz ${ }^{3}$ e desde então, pôde aliar crítica às suas posturas e convicções políticas de esquerda, de modo a projetar na arte o papel de instrumento libertador do homem contra as amarras do capitalismo. Pedrosa esteve atento e acompanhou o que se passava no Brasil e no mundo, tanto no campo das artes como da política e das conjunturas internacionais, e como convicto trotskista que era, via claramente a relação das vanguardas européias com ideologias políticas e de como a arte poderia ser reescrita no processo histórico através do viés social, e principalmente da potencialidade que ela tem para isto. Esta sua posição evidenciou-se nas discussões e atitudes políticas e críticas, uma vez que jamais dissociou revolução social e arte de vanguarda. Os contundentes textos que escreveu, revelam o teor do seu engajamento político, engajamento este fundamental em seu modo de pensar a arte como elemento transformador e ativo na sociedade.

Como trotskista, e por defender idéias consideradas subversivas à ordem, Pedrosa passou períodos de exílio na Europa e nos Estados Unidos e trabalhou intensamente como adido cultural da AICA, organizando conferências, júris e exposições. Estudou filosofia, sociologia e estética na Universidade de Berlim, entre os anos de 1927 e 29, onde conheceu e estudou a teoria da Gestalt, ou a psicologia da forma, que será a partir de então, como uma referência para suas análises plásticas e o ponto chave para seu entusiasmo em relação à abstração e ao concretismo, dos quais será importante leitor e incentivador.

Durante a década de 1930, Mário Pedrosa esteve envolvido com a militância política e com assuntos relacionados ao partido trotskista brasileiro e secretaria a IV Internacional comunista. Em 1941, o crítico exila-se nos Estados Unidos onde trabalhou na União Panamericana. Frequentou os círculos artísticos norte americanos e conheceu a obra de Alexander Calder. Em 1945, Mário Pedrosa retornou ao Brasil e passou a colaborar para o Correio da Manhã, e posteriormente no O Estado de São Paulo e na Tribuna da Imprensa. Embora não abandonasse as atividades dos trâmites políticos de sua militância, o crítico dedicou-se, neste período, mais intensamente à crítica de arte e à organização de exposições.

\footnotetext{
${ }^{3}$ Encontram-se duas grafias para o nome da artista alemã. Verifica-se no texto de Mário Pedrosa As tendências sociais na arte de Kaethe Kollwitz publicado em Arte, necessidade vital, em 1949, o emprego da grafia "Kaethe". Quando o texto foi compilado e republicado por Otília Arantes em 1995, no volume I Política das Artes de sua coleção sobre Mário Pedrosa, a organizadora opta grafar o nome da artista como Käethe Kollwitz. Neste trabalho optou-se manter a grafia "Kaethe", assim como Mário Pedrosa a usara originalmente.
} 
Já em meados dos anos de 1940 acompanhou as atividades da Dra. Nise da Silveira no Hospital Psiquiátrico Pedro II, como espectador e como crítico.

No fim desta década, Mário Pedrosa esteve envolvido com os projetos de criação do Museu de arte Moderna de São Paulo e da Bienal de São Paulo. Além de colaborar para organização de júris e exposições. Além de atividades práticas, o crítico contribuiu para uma estética abstrata no Brasil, que ainda nos anos 1950 era vista com desconfiança na cena nacional. Proferiu e acompanhou debates, além de estimular os artistas para novas pesquisas estéticas. Influenciados pelas premissas abstratas, e articulados em torno da figura de Mário Pedrosa, Ivan Serpa, Almir Mavignier e Abraham Palatinik, organizaram um grupo de artistas abstrato-concretos no Rio de Janeiro. A este grupo somaram-se diversos outros artistas, que posteriormente formaram o grupo Frente. O núcleo carioca, no entanto, marcaria a história da abstração, pois partiu de premissas formais, sobretudo vinculadas às influências das teorias da forma, e dedicou-se às livres experimentações da forma, na criação de objetos. Não se apoiaram em preocupações políticas, e mantiveram-se envolvidos com pesquisas estéticas.

Enquanto isto em São Paulo, organizou-se um grupo de artistas abstratos em torno da figura de Waldemar Cordeiro, que também assumiu papel critico além de artístico. A arte concreta do núcleo paulista carregava uma forte conotação política marxista, e constituiu uma produção vinculada à premissa de Gramsci sobre o papel do artista de orientar a formação cultural das massas e adotou uma ortodoxia geométrica racionalmente organizada. Este grupo posteriormente denominou-se como Grupo Ruptura. Mário Pedrosa também manteve-se à par das atividades deste grupo e escreveu sobre suas exposições. A dissidência entre os dois núcleos aconteceu em 1957, quando os artistas cariocas criaram um movimento chamado de neoconcreto.

Durante a década de 1960, o crítico manteve-se envolvido com atividades de Presidência da Associação Brasileira de Críticos de Arte, e de vice-presidência da Associação Internacional de Críticos de Arte, organizando e visitando exposições e congressos de críticos. Atuou como diretor do MAM/SP e organizou a VI Bienal de São Paulo. Com o recrudescimento da política nacional, Mário Pedrosa se dedicou à escrita de livros políticos como A opção imperialista e A Opção Brasileira e por restrições e perseguições impostas pelo governo militar partiu para o exílio em 1970.

Em seus últimos exílios foi para o Chile apoiar o governo esquerdista de Salvador Allende, e ali atuou como adido cultural onde fundou o Museo de la Solidariedad, e compôs um importante acervo de arte moderna à partir de doações de obras de artistas e críticos. Neste período trabalhou no Instituto de Arte Latino-americana e lecionou História da Arte na 
Faculdade de Belas Artes do Chile. Com o golpe militar que depôs o governo de Allende, Pedrosa refugiou-se na embaixada do México, e meses depois seguiu para Paris na condição de refugiado político. Mesmo no exílio e já com idade avançada, se envolveu com exposições e escreveu textos críticos para revistas de diversos países. Retornou ao Brasil em 1977 e em 1980, como uma de suas últimas realizações participou ativamente na fundação do Partido dos Trabalhadores, sendo seu filiado número um.

Um vislumbre do percurso intelectual, crítico e político de Mário Pedrosa situa-nos sobre a envergadura e a erudição de sua produção. Tendo em vista as realizações críticas, institucionais e artísticas de Mário Pedrosa pode-se concluir, tratar-se de uma figura ímpar na história da crítica de arte brasileira. A sua atuação militante e sua atualização crítica são reveladoras de seu compromisso com a arte e com a utopia da Revolução Social. Mário Pedrosa deflagrou suas idéias por meio de suas críticas, e são elas que testificam de suas estratégias e convicções.

\section{AS PERSPECTIVAS DESTA DISSERTAÇÃO}

Mário Pedrosa dedicou sua vida às suas convicções políticas e estéticas. E como tal, suas principais ideias e formulações encontram-se expressas, sobretudo em artigos jornalísticos, tendo em vista que colaborava diariamente para importantes jornais brasileiros. Há também, obras publicadas pelo próprio autor, e textos seus que foram compilados e republicados posteriormente. Sendo assim, propusemos com esta pesquisa, o estudo atento, a preservação e a valorização de documentos e obras produzidos por este importante crítico, que se volta para a produção especializada brasileira no campo da crítica de arte. Sua atuação crítica envolveu também, os movimentos artísticos emergidos neste contexto das referidas décadas. A problemática geral reside em averiguar o que Mário Pedrosa escreveu e refletiu sobre a arte da década de 1950, sobretudo porque se trata do momento em que se delineia a discussão sobre o que caracteriza a arte moderna e quais seus estatutos conceituais.

Neste sentido, esta dissertação visa alçar uma reflexão sobre a produção e contribuição crítica de Mário Pedrosa para a arte brasileira, como também delinear alguns de seus paradigmas artísticos que colaboraram para a consolidação de um arcabouço teórico para História da Arte Moderna, tanto no plano nacional, quanto internacional. Este trabalho assenta-se como um desdobramento de pesquisas que vêm sendo realizadas desde a iniciação 
científica, quando trabalhei com a crítica de Mário Pedrosa e seu vínculo com a Associação Brasileira de Críticos de Arte e sua congênere internacional. Neste momento de pesquisa, reuni uma grande quantidade de textos críticos de Pedrosa, em arquivos e centros de documentação, com o objetivo de delinear um histórico sobre os temas abordados pelo crítico nas décadas de 1950 e 1960. Os documentos reunidos revelaram que a produção crítica de Mário Pedrosa nas referidas décadas abordavam as reflexões deste pensador da cultura sobre a arte de seu tempo e as transformações de sua época.

Diante de sua prolífera produção constatou-se uma impossibilidade em delinear pontualmente os temas tratados, uma vez que o crítico abordou uma infinidade de conteúdos e de problemas. Suas críticas dirigiram-se a diversos artistas de diferentes movimentos estéticos e de distintas linguagens. Mas, de certa forma, determinados conjuntos de textos de cada período revelaram premissas comuns, que encaminhavam certa orientação estilística na escrita e na crítica. Sobretudo nos textos críticos da primeira metade da década de 1950 há uma preocupação com a emergência da abstração no Brasil e com as interpretações do abstracionismo. Situa-se um debate vinculado ao afastamento premeditado da figuração, em benefício do desenvolvimento de linguagens que traduzissem novas percepções e sensibilidades. Na segunda metade da década, nota-se um crítico mais interessado pela técnica e pela ciência da tecnologia, como também pela problemática do espaço que estará vinculada às preocupações artísticas próprias dos anos de 1960. Encaminhava-se, assim, para outros direcionamentos estéticos e conceituais, e onde o próprio Pedrosa diagnosticou uma dissidência com os paradigmas modernos, levando-o precocemente a nomeá-la de uma era pós-moderna.

A proposta inicial do trabalho remetia-se a um arco temporal mais abrangente, a saber, entre as décadas de 1930 e 1960, a começar com sua estreia na crítica sobre Kaethe Kollwitz até seu envolvimento com o neoconcretismo. Porém, ao considerar a profundidade e a quantidade de sua produção crítica, que somam mais de 600 artigos, fez-se necessária, como uma estratégia metodológica, a opção por uma abordagem temática. Ao verificar-se que o recorte temporal de várias décadas oferecia uma gama exaustiva de artigos e temas, notou-se tratar de uma tarefa hercúlea, que não se bastaria contemplada em um curto processo de mestrado. Assim, ao considerar a complexidade dos temas abordados pelo crítico e as mudanças de paradigmas que alteram o curso de suas ideias, optou-se por um recorte com o objetivo de alcançar uma compreensão pormenorizada e lúcida de um conteúdo em particulara questão da percepção da forma. 


\section{DA PROBLEMÁTICA ESPECÍFICA}

A análise da arte contemporânea à sua época, realizada sob a ótica da gestalt é um tema caro à atuação crítica de Mário Pedrosa, pois se trata de perscrutar a própria abordagem teórica, o instrumental metodológico para a análise crítica. É desta forma uma abordagem importante para compreender as idéias e as reflexões plásticas lançadas em seus artigos críticos. O desenvolvimento da psicologia experimental afluiu grande soma de conhecimento às diversas disciplinas da ciência, oferecendo novos instrumentos de compreensão do homem e de sua percepção de mundo, e ao colaborar para esta compreensão, o crítico oferecia subsídios teóricos para embasar investigações estéticas de modo coerente e seguindo prescrições científicas.

A influência deste pensamento e da escola gestaltista deveu-se à própria formação que Pedrosa recebeu. Tendo ido estudar na Suíça e na Alemanha, o crítico recebeu, em sua formação acadêmica, uma influência direta do pensamento alemão. Entre 1927 e 29 estudou filosofia, sociologia e estética na Universidade de Berlim, onde começou a visitar o tema da gestalt e estabeleceu um primeiro contacto com as idéias de intelectuais como Max Wertheimer, Kurt Koffka, Wolfgang Köhler que desenvolviam estudos sobre a psicologia da forma, os quais, a partir da psicologia experimental fundamentavam a ciência gestáltica. Posteriormente, quando em exílio nos EUA, devido à perseguição política do Estado Novo no Brasil, Pedrosa novamente imerge nos conceitos gestálticos em aulas que assistirá ali com professores americanos e alemães refugiados da guerra- um deles teria sido o próprio Max Wertheimer. Vários manuscritos seus versam sobre reflexões e explanações obtidas e desenvolvidas nestas aulas e conferências.

Em 1949 Pedrosa apresenta uma tese para concurso catedrático de História da Arte na Faculdade Nacional de Arquitetura, intitulada "Da natureza afetiva da Forma na Obra de Arte”, um estudo pioneiro onde efetua uma aplicação sistemática dos ensinamentos da Gestalt à arte. Pedrosa irá embasar-se nas ideias propostas pelos teóricos da percepção para formulação de seu estudo que relaciona as teses da psicologia da forma e as atribuições intrínsecas do objeto artístico. As questões enunciadas pela psicologia da forma somarão instrumentos teóricos e metodológicos para a constituição de suas análises plásticas, e neste sentido, Mário Pedrosa foi um dos primeiros brasileiros a relacionar tais teorias da percepção 
com a arte, e assim evidenciar a força expressiva da forma e de sua capacidade na reeducação da sensibilidade do espectador.

Seu estudo é, ainda, anterior à tese de Rudolf Arnheim sobre a percepção visual da arte, que fora publicado em 1954 e que até a atualidade segue como referência para pesquisa sobre a percepção da forma na arte. No entanto, como o trabalho de Pedrosa restringiu-se ao concurso no qual participou, sua tese permaneceu por muitos anos desconhecida do grande público, tendo sido somente publicada em 1979, quando estas teorias já estavam no domínio dos artistas e inclusive sendo revisadas e ampliadas com outras acepções de outras premissas estéticas.

Mário Pedrosa acreditava que somente seria possível apreender a arte em sua essência e significação, quando se compreendesse a percepção humana. Neste sentido, interessa-se em identificar os mecanismos perceptivos, através das teorias dos gestaltistas, para posteriormente reconduzi-los à fruição artística. Perseguindo estas questões, é objetivo e foco deste trabalho se dedicar à análise do interesse de Mário Pedrosa pela gestalt, a partir de seu estudo sobre a sua tese "Da natureza afetiva da forma na obra de arte", proferida em 1949, em que o crítico alia teses experimentais da psicologia à análise do objeto artístico. A partir das idéias desenvolvidas neste estudo do crítico, objetiva-se buscar a reverberação destas formulações na construção da análise de Pedrosa sobre a criação artística, o produto artístico e o espectador. Desta forma, a abordagem eleita não é de cunho cronológico, mas sim temático. Para tanto trabalharemos com textos críticos de Mário Pedrosa de diferentes épocas e contextos, mas, sobretudo, mantendo o foco sobre a abordagem de questões como percepção, questões da forma e experiência estética. Assim, o interesse deste trabalho se coloca na direção de delinear uma relação entre o que Pedrosa absorveu em seus estudos na Europa e nos Estados Unidos sobre a gestalt e exemplos de como ele as aplicou na tessitura do discurso crítico.

Ao desenvolver a dissertação, não se pretendeu uma abordagem técnica e especializada sobre o tema da gestalt, uma vez que minha formação acadêmica em História não ofereceria subsídios teóricos para tal infiltração. Não foi nosso objetivo prender-se ao estudo pormenorizado dos conceitos gestálticos e à sua sistemática, uma vez que tal empreendimento exigiria um conhecimento específico que, no momento, não é o nosso foco. No entanto, o interesse pelo tema aponta para um delineamento histórico da aproximação de Mário Pedrosa com as teses gestálticas com o objetivo de constituir um panorama de sua formação e de contato com o tema, e através deste arco histórico, ressaltar o interesse do 
crítico por estas teorias, a ponto de absorvê-las em suas críticas e em um estudo em particular que foi sua tese de 1949.

No desenvolvimento da pesquisa, foram localizados no acervo que pertenceu a Mário Pedrosa, e que hoje pertence à coleção da Biblioteca Nacional do Rio de Janeiro, diversos títulos sobre a questão da gestalt e a psicologia da forma, sobre a apreensão do olhar e sobre a questão da criação artística. A presença de tais títulos na coleção constituída pelo crítico evidencia o seu profundo interesse pelas questões da forma e da percepção visual na obra de arte. Ainda na coleção deste acervo, localizaram-se diversos manuscritos de fichamentos de leituras sobre a gestalt, seguidos de reflexões que debatem e problematizam as mesmas questões e preocupações enunciadas nos títulos de sua coleção. Vários textos traziam anotações como "este é o problema de minha tese" seguidos de trechos sublinhados e destacados. Estes manuscritos formam parte dos estudos realizados por Pedrosa para a escrita de sua tese sobre "Da natureza afetiva da forma na obra de arte", que segundo os textos e anotações verificadas foi a preocupação central do crítico nas décadas de 1940 e 1950. Tamanho foi o envolvimento de Mário Pedrosa com o tema, que excedeu a pura curiosidade e atualização científica, a ponto de ser o tema deste complexo estudo de 1949. Esta foi também a estratégia que usou para análise de obras, sobretudo abstratas, foi a base metodológica para a composição de seus textos críticos sobre elas.

A pesquisa no Acervo Mário Pedrosa na Biblioteca Nacional evidenciou claramente a consistência do argumento da abordagem de nossa pesquisa, uma vez que a problemática da percepção da forma e o envolvimento e interesse pelas estéticas abstratas e concretistas foram uma preocupação central na sua fortuna crítica: a contínua recorrência do assunto nos escritos e materiais presentes no acervo do crítico.

A metodologia empregada para elaboração deste trabalho é a histórico-documental. Selecionou-se de um conjunto de textos críticos, os relevantes à abordagem eleita- psicologia da forma- eles foram ordenados por sua abrangência relativa à este tema e partiu-se então para descrição e análise de seus respectivos conteúdos.

Para o desenvolvimento e ordenação do texto, o método utilizado delineou inicialmente um histórico da formação de Mário Pedrosa, nos períodos em que esteve na Alemanha e nos Estados Unidos. Situada sua formação, partimos a um enfoque da tese $D a$ natureza afetiva da forma na obra de arte, onde o crítico apresenta a perspectiva artística em diálogo com a psicologia da forma. Finalmente, identificamos as ideias do autor a partir de um exercício de leitura da crítica de arte sobre a arte de Alexander Calder, tendo em vista influências conceituais da escola gestáltica. 
As idéias analisadas permitem a reconstrução de todo um momento histórico do cenário artístico brasileiro e de seu contato com a realidade internacional. São documentos de abordagens sobre os acontecimentos artísticos tanto do cenário brasileiro, como também internacional. A considerar que a consolidação de um pensamento não se vincula a balizas temporais, há documentos e textos de diferentes momentos, estando, porém, concentrados, sobretudo, nas décadas de 1940-50, no período de gestação e o amadurecimento de uma base teórica da arte Moderna, por ele construída. O foco incide sobre o momento em que começa a discussão sobre o que caracteriza a arte abstrata, sobre a qual, o discurso de Pedrosa lançará bases e estruturas teóricas, inclusive acerca de seus estatutos e sobre qual será o lugar e o papel da crítica de arte neste novo contexto.

\title{
DA RECEPÇÃO DO TEMA
}

Abordar a questão da relação entre Mário Pedrosa e a gestalt aparece-nos como uma celeuma, ainda não bem resolvida no seio do debate acadêmico entre os especialistas. $\mathrm{O}$ tema assenta-se com certa fragilidade entre os pesquisadores, sobretudo pelo fato de o próprio Pedrosa ter dito,em 1979, na ocasião da publicação de sua tese Da natureza afetiva da forma na obra de arte, que não tinha mais nada a ver com a gestalt. A partir desta assertiva, algumas vozes dentro do círculo de especialistas rejeitam esta abordagem como uma etapa superada e obliterada dentro da produção do crítico.

Ao tratar sobre esta problemática, assumimos a mesma reticência que a expressa por Frayze-Pereira (2007, p 130):

\begin{abstract}
No entanto, devo dizer que considero uma temeridade escrever sobre esse autor (Mário Pedrosa) depois dos escritos da professora Otília Arantes- prefácios e ensaios esclarecedores no campo da filosofia e no da crítica de arte que levam o leitor a concluir ter sido Mário Pedrosa não apenas um grande crítico, mas um instigante pensador da cultura. Haveria algo mais a dizer? ${ }^{4}$
\end{abstract}

Ao inserir-se neste debate, não se pretende uma revisão bibliográfica sobre o assunto a fim de propor uma solução epistemológica para esta abordagem.

\footnotetext{
${ }^{4} \mathrm{O}$ autor evidencia a profundidade e a seriedade dos estudos sobre Mário Pedrosa desenvolvidos por Otília Arantes. A impressão descrita pelo autor é comum às pesquisas que se desenvolvem sobre o tema.
} 
Assinaladas estas considerações, destacamos haver pouca bibliografia específica que se detenha sobre esta questão. Dentre a fortuna crítica levantada sobre esta problemática assinalamos a obra de Otília Arantes, que se empenhou em resgatar e traçar os principais elementos teóricos do percurso intelectual de Mário Pedrosa, sob o ponto de vista da estética e da filosofia. De todo o material reunido e analisado por ela, destacamos o prefácio "Mário Pedrosa, um capítulo brasileiro na teoria da abstração" para o volume III intitulado Forma e Percepção Estética, no qual a pesquisadora reuniu textos do crítico sobre o problema da forma e da percepção, como sugere o título homônimo. Este prefácio produzido por Otília Arantes é parte de escassos trabalhos que se detiveram sobre a análise desta fase importante da produção crítica de Pedrosa. Este trabalho foi-nos um direcionamento norteador, por assinalar o contato e engajamento do crítico com a arte abstrata e por delinear suas filiações teóricas e assimilações críticas. Destacamos ainda, que o prefácio aborda ainda outras questões em profundidade, que não foram continuadas neste trabalho, por implicações metodológicas de recorte temático.

Outro trabalho que se destaca neste cenário sobre Mário Pedrosa e a psicologia da forma, e que foi-nos igualmente esclarecedor para o debate proposto neste trabalho, é o artigo de João Frayze-Pereira intitulado Estética da Forma: Mário Pedrosa- crítica de arte, psicologia e psicanálise que foi apresentado no Colóquio Utopias Geométricas e Construtivas- Projeto Arte no Brasil: Textos Críticos do século XX, realizado na Faculdade de Arquitetura e Urbanismo da Universidade de São Paulo em junho de 2007. Este artigo situa o debate da produção crítica de Mário Pedrosa e a gestalt, dentro das disposições teóricas próprias do campo da psicologia. João Frayze-Pereira situa a tese de Pedrosa de 1949, como uma tentativa de elucidar uma teoria Estética da forma, a fim de atribuir à arte uma fundamentação científica e superar a dicotomia subjetividade/objetividade que norteava as críticas sobre o fenômeno artístico. A análise de Frayze, no entanto, vai além identificando o esgotamento e a insuficiência da teoria gestáltica diante de outras premissas artísticas, e as limitações de seu "preconceito cientificista". O autor situa então, a fenomenologia como uma premissa que completa e assegura as implicações estéticas e filosóficas que escapavam ou faltavam às teses gestálticas.

Dentro ainda dos estudos da psicologia, ressaltamos o trabalho de Gustavo Henrique Dionísio intitulado $O$ antídoto do mal- Sobre arte e loucura, Mário Pedrosa e Nise da Silveira, onde enlaça o interesse e envolvimento de Mário Pedrosa com o trabalho de arteterapia desenvolvido pela psiquiatra Dra. Nise da Silveira com os portadores de doenças mentais no antigo Centro Psiquiátrico Pedro II em Engenho de Dentro, na cidade do Rio de 
Janeiro. O envolvimento de Pedrosa e a análise de seus textos críticos sobre a produção artística daqueles pacientes revelam sua preocupação com a questão da forma e suas inquietações com relação às formas criativas de mentes com perturbações psíquicas. Esta experiência foi-lhe um "laboratório" estético na medida em que pode observar as produções artísticas dos pacientes e relacioná-los com as estruturas intrínsecas da obra de arte e da fisiologia mental anunciadas pelas teses da psicologia da forma.

Outros autores como Paulo Herkenhoff e Frederico Morais destacam a importância das teses da gestalt no trabalho do crítico, sem, no entanto, desenvolverem uma análise detida sobre o assunto.

\section{ESTRUTURA DO TEXTO}

Com o objetivo de historiar as aproximações de Mário Pedrosa com as perspectivas da psicologia da forma, e organizar os enfoques norteadores para o desenvolvimento da problemática, estruturou-se o estudo em três segmentos: Inicia-se com um panorama histórico, segue uma descrição atenta da tese de 1949 e verifica-se, no último setor, a aplicação destas premissas na tessitura crítica.

No primeiro capítulo, objetiva-se desenvolver um panorama histórico do contato de Mário Pedrosa com a teoria gestáltica, como também, um panorama de suas influências estéticas que o encaminham a estes interesses. Ao considerar a formação do crítico como um elemento fundacional para suas premissas, desenvolve-se uma descrição dos fatos históricos e dos ambientes acadêmicos que Pedrosa frequentou. Por este motivo, grande parte do capítulo é dedicado às descrições do ambiente intelectual e político germânico, oferecendo uma possibilidade de assinalar a formação acadêmica que o crítico assimila na Universidade de Berlim, como também o vislumbre do panorama artístico e intelectual que circulava pela Berlim dos anos 1920.

Ao passar pela conjugação entre arte e política na ocasião do texto sobre Kaethe Kollwitz, assinala-se então, as influências estéticas da abstração, sobretudo nas figuras de Wassily Kandinsky e Piet Mondrian como ícones fundamentais para constituição de uma gramática abstrata, como também na assimilação das teorias gestálticas em suas pesquisas e realizações. Estes dois artistas são fulcros elementares para a discussão que se aloca em torno da adoção de uma estética não-figurativa e sedimentam textos críticos que orientam as 
vertentes abstratas a partir de então. Kandinsky se encaminha para uma vertente lírica, enquanto Mondrian direciona-se para um vocabulário construtivo e geométrico. Assinala-se ainda o envolvimento destes na Escola da Bauhaus e a relação desta com as premissas da estética da forma.

Por via de um panorama conceitual, situa-se as concepções de Mário Pedrosa sobre a arte abstrata e de seu envolvimento com esta estética. Como continuidade deste contexto, situa-se um prospeto do cenário norte americano dos anos de 1930, uma vez que a grande maioria dos intelectuais e artistas do contexto alemão se viram forçados à migração para os EUA por causa de perseguições impostas pela ascenção do governo nazista.

Do ambiente norte americano, constrói-se um panorama dos círculos artísticos que se desenvolviam nos grandes centros, sobretudo Nova York, cidade despontando como um polo urbano-industrial moderno e que aglutinava novas instituições que passariam a gerenciar as demandas artísticas e culturais a partir de meados dos anos 1940. Situa-se também, uma perspectiva da crítica de arte realizada neste círculo, na figura do crítico Clement Greenberg e de suas teorias sobre o expressionismo abstrato, que marcaria a ascenção dos artistas norteamericanos. Em contrapartida, conclui-se o capítulo com um paralelo entre estes dois críticos importantes, Mário Pedrosa e Clement Greenberg.

O segundo capítulo aborda um estudo descritivo específico sobre a tese Da Natureza Afetiva da Forma na Obra de Arte, no sentido de delinear as premissas gestálticas que Pedrosa assimilou. Objetiva-se compreender o esquema conceitual da psicologia da forma, através da abordagem que o crítico desenvolve sobre o tema. Ao deter-se em um único texto crítico, propõe-se um diálogo com as idéias contemporâneas à tese, ou com autores que desenvolveram outras orientações estéticas para as mesmas problemáticas. No entanto, para não perder o elo conceitual constituído por Pedrosa, optou-se por desenvolver estas relações conceituais no corpo das notas de rodapé, com o objetivo de dedicar o corpo do capítulo para centrar-se nos conceitos propostos pelo crítico.

A disposição e o debate dos temas orienta a ordenação conceitual da própria tese. Inicia-se a discussão com um delineamento das leis da gestalt que regem a estrutura da percepção visual. Num segundo momento, parte-se à relação Forma e significação, no sentido de assinalar o processo mental que atribui significação cognitiva ao fenômeno percebido. Em sequencia o texto encaminha-se para o debate sobre a forma artística e suas especificidades conceituais. Discute-se também a gênese das representações e emoções, com o objetivo de compreender a elaboração cerebral de um sentido para proposições formais artísticas que nos chegam à percepção. Com o intuito de contextualizar o debate acadêmico das ideias de Mário 
Pedrosa finalizamos o capítulo com uma discussão sobre a repercussão nacional e internacional desta tese.

O terceiro e último capítulo está dedicado à intersecção entre a psicologia da forma e a crítica de arte de Mário Pedrosa. Objetiva-se, assim, situar a medida em que, seu discurso crítico absorveu os conceitos gestálticos e os aplicou em sua tessitura e designações críticas. Para esta discussão, foram tomados os textos críticos sobre a obra do artista americano Alexander Calder, por ser considerado por Pedrosa como o emblema da estética abstrata construtiva. Optou-se pelos textos, Calder, Escultor de Cataventos e Tensão e coesão na obra de Calder, pois abordam ideias e construções teóricas que evidenciam como as teses da escola gestáltica foram marcantes e claramente presentes no vocabulário crítico de Mário Pedrosa neste período.

Embora, sabendo que posteriormente o crítico se encaminhou para outras filiações teóricas, defende-se a importância desta abordagem no período situado entre os anos de 1940 e 1950. As teses propostas pela psicologia da forma oferecem-nos subsídios conceituais e processuais para uma nova relação com as premissas constitutivas e cognitivas da estética abstrata. Se a abstração propunha um novo conteúdo estético que escapava à figuração, eralhe necessário um outro cabedal teórico que lhe fundamentasse a percepção e a agregação da significação. As teses da gestalt foram para Mário Pedrosa a fundamentação para a crítica sobre a arte deste período. 


\section{PANORAMA DAS IDEIAS DE MÁRIO PEDROSA}

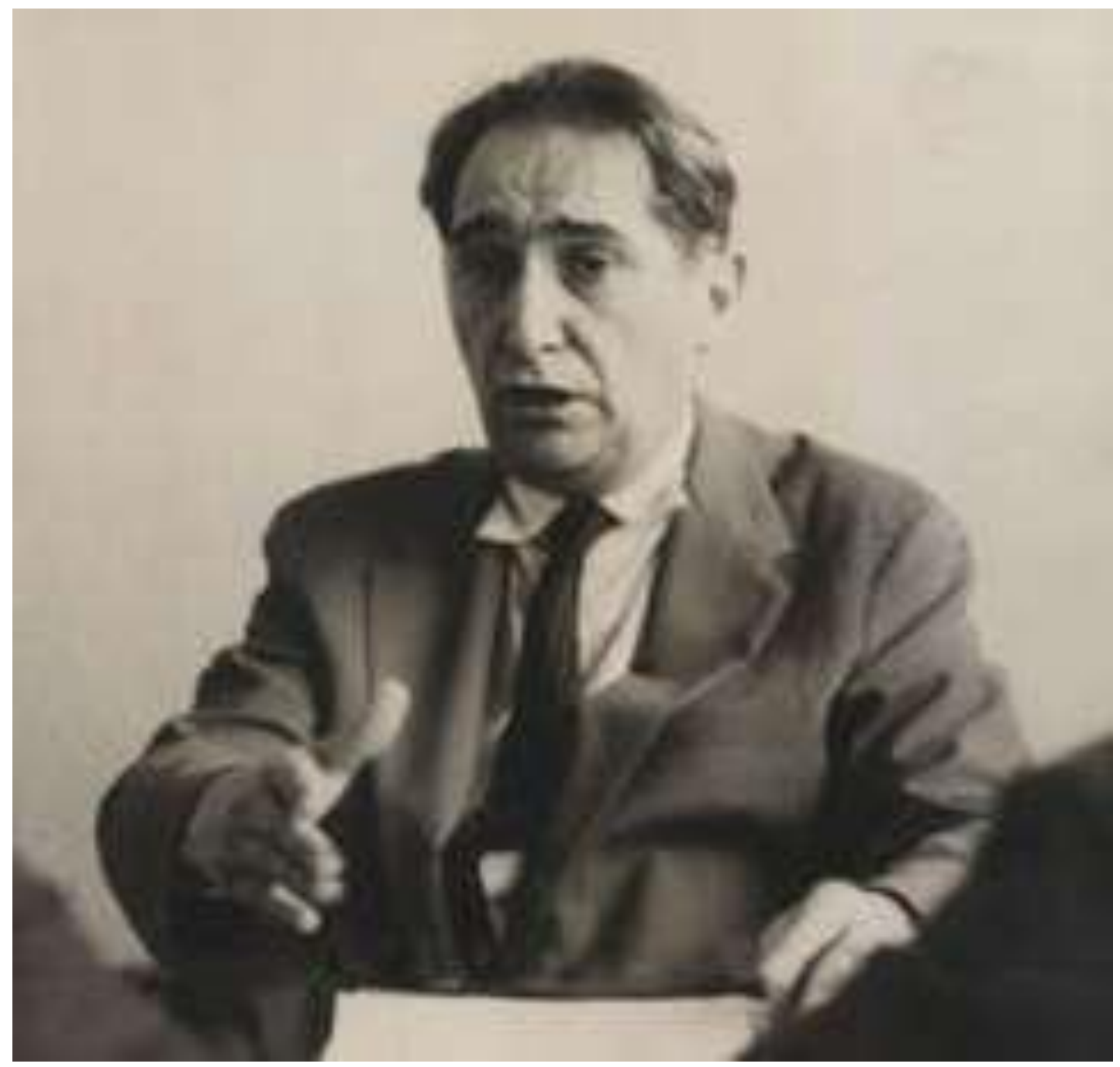

Figura 1: Mário Pedrosa.

Fonte: http://www.estadao.com.br/noticias/impresso,moma-edita-obra-de-mario-pedrosa,721589,0.htm 


\subsection{MÁRIO PEDROSA E A CRÍTICA DA ARTE MODERNA NO BRASIL: PRIMEIROS MOMENTOS}

A atividade crítica facilita a compreensão dos movimentos e acontecimentos que emergem no cenário cultural. A sua presença vislumbra a participação e influência na vida artística e na maneira pela quais os críticos recebem e reconstroem a arte em seu contexto intelectual e social. A crítica de arte sempre teve um importante papel, de aproximar o público da obra e, sobretudo, de esquadrinhar os códigos da arte para que os espectadores a apreendam de modo mais completo e também adentrem sua complexidade.

Pedrosa esteve atento e acompanhou o que se passava no Brasil e no mundo, tanto no campo das artes como da política e das conjunturas internacionais, e como convicto trotskista que era, via claramente a relação das vanguardas européias com ideologias políticas. Para ele, era claro o fato de que a arte poderia ser reescrita no processo histórico através do viés social, e principalmente da potencialidade que ela tem para isto. Esta sua posição evidenciou-se nas discussões e atitudes políticas e críticas, uma vez que jamais dissociou revolução social e arte de vanguarda. Os contundentes textos que escreveu revelam o teor do seu engajamento político - engajamento este fundamental em seu modo de pensar a arte como elemento vivo e transformador na sociedade.

Mário Pedrosa insere-se no campo da crítica, primeiramente pelo viés da literatura, resenhando textos e tecendo considerações sobre livros em artigos jornalísticos, uma prática corrente de intelectuais que se inseriam na imprensa e nos círculos de debates sobre a produção cultural brasileira. Assim como seus pares, Mário de Andrade, Oswald de Andrade, Ronald de Carvalho, Menotti Del Picchia entre diversos outros nomes, Pedrosa inicia suas atividades intelectuais no jornalismo cotidiano.

Neste circuito, em meados de 1920, Pedrosa começa a freqüentar as idéias dos iniciados modernistas brasileiros e a ter um contato direto com a expressão do campo artístico, principalmente pela convivência com Mário de Andrade e Plínio Salgado na redação do Diário da Noite. No entanto, neste período, as preocupações de Pedrosa eram intrinsecamente políticas, uma vez que se envolvera com os movimentos de esquerda nos anos da Faculdade de Direito que cursara no Rio de Janeiro. Balizado pelo próprio contexto abrasivo do entre guerras, Pedrosa interessou-se por questões do marxismo e engajou-se nas manifestações partidárias. Como fruto de uma conscientização histórica do contexto vivido, era recorrente à grande parcela da intelectualidade deste período compartilhar ou rivalizar 
idéias partidárias ou vertentes ideológicas em plena ascensão nas práticas políticas dos grandes centros mundiais, como também das periferias.

Embora o Brasil estivesse na periferia do mundo dito "culto", ou seja, nos arrabaldes dos núcleos irradiadores da cultura, os artistas, jornalistas e teóricos da cultura brasileira logravam manter-se a par das novidades propostas nos círculos intelectualizados da Europa. A elite intelectual brasileira sentia a necessidade de atualizar as linguagens da literatura e da arte e enveredar-se pelo surto de modernização que sedimentava novas formas de percepção e de pensamento sobre a cultura.

Esta geração de intelectuais dos anos de 1920 e 30 buscava a atualização artística e a concatenação da cultura brasileira com as realizações internacionais, principalmente européias. Expressavam uma atuação ainda claudicante e carente de instituições consolidadas que os respaldassem de modo mais significativo, mas que se caracterizou como uma geração comprometida em traçar um projeto moderno para o país e articular um constructo cultural brasileiro.

Neste contexto se insere a atuação de Mário Pedrosa, importante crítico de arte cuja produção contribui para a formulação da base teórica e analítica da arte moderna brasileira. Sua crítica ainda hoje apresenta relevância para o pensamento sobre arte brasileira. Portador de uma sólida erudição, Pedrosa transitava com proficiência entre as diversas ciências das humanidades. Ele considerava que a crítica precisava se renovar, revendo idéias, métodos e rigores, e reunia toda gama de conhecimentos específicos - teoria e história da arte, filosofia, psicologia, atualização científica e formação política ${ }^{5}$ (ARANTES, 1991, p. 15) - para que a crítica proferida fosse embasada, criteriosa e acompanhasse o processo de modernização de uma sociedade em transformação e englobasse as novas teorias e debates de uma realidade em ebulição. Mostrava-se como um crítico expressamente preparado para informar e formar o público para uma recepção estética multifacetada e polissêmica. Iniciou-se no campo artístico como um crítico inteirado às linguagens estéticas do movimento moderno e ciente da necessidade de atualização das artes no Brasil, fosse por meio da criação de instituições de arte, fosse por meio do debate sobre as teorias artísticas.

\footnotetext{
${ }^{5}$ Conteúdo parafraseado p. XV.
} 


\subsection{PERCURSO E FORMAÇÃO DE SEU PENSAMENTO}

Mário Pedrosa é marcadamente um pensador político. No entanto, ele não somente atuou na cena política, na construção de uma esquerda consistente e coerente com seus pressupostos trotskistas, mas também se dedicou à crítica de arte, por ver na arte um campo em potencial para a sensibilização do homem destinado à Revolução Social, projeto este que seguiu em toda sua produção crítica e política. Assim o percurso profissional e intelectual de Pedrosa é o resultado da conjugação entre arte e política e embora, a orientação política de esquerda seja uma constante no seu discurso crítico, esta questão não permanece como o cerne das discussões críticas ao longo de sua produção. Ao se inserir na crítica de arte, Pedrosa adequa suas convicções políticas ao campo artístico e se dedicará às análises artísticas como um perito esteta. Se em um primeiro momento de sua produção crítica nos anos de 1930 o seu discurso traz o vocabulário ideológico da esquerda- a exemplo da crítica sobre Kaethe Kollwitz - a produção da década seguinte revela um profundo mergulho nas discussões epistemológicas e estéticas da produção artística.

Pedrosa foi um dos poucos no Brasil a relacionar crítica de arte com pesquisas interdisciplinares. Seu interesse em assuntos afins, respondia aos anseios de desenvolver uma análise crítica atenta às novas teorias que invadiam as ciências e as artes e que atribuísse ao discurso artístico o selo da cientificidade, escapando de uma crítica opinativa e meramente observadora do gosto. O crítico embasava suas idéias no diálogo entre arte e ciência e procurava desenvolver as críticas e teorias estéticas com paradigmas e atributos científicos. Para tal, Pedrosa acumulou, ao longo de seu percurso intelectual, um denso acervo cognitivo de leituras e estudos de áreas afins, de modo a apresentar a preparação exigida para o empreendimento a que se dedicou.

Esta postura interdisciplinar em sua abordagem crítica é fruto da própria formação que traçou em seu percurso escolar e universitário. Assim como a maioria dos filhos da elite, fora enviado a estudar na Europa, na Suíça. A permanência no exterior foi interrompida com a guerra de 1914, quando a família decide trazê-lo de volta ao Brasil. Ao longo dos anos 1920 e 1930, Mário Pedrosa fora antes de tudo um ativista político e militante de esquerda. Fundou a Revista Proletária, que teve logo a publicação empastelada pela polícia. Por sua atuação contundente, a representação do Partido Comunista Brasileiro decidiu enviá-lo como comissário a estudar na Escola Leninista em Moscou, mas adoeceu e, sem condições físicas de enfrentar o inverno rigoroso russo, permaneceu em estágio em Berlim. Como militante 
comunista, tomou parte em protestos de rua contra nazistas. Retido na Alemanha, entre os anos de 1927 e 1929 estudou filosofia, sociologia e estética na Faculdade de Filosofia da Universidade de Berlim. Foi nestas aulas que Pedrosa teve contato com as teorias estéticas e com a psicologia da forma, onde se interessou pelas teses da gestalt que por muito tempo, serão para ele, um instrumento teórico e metodológico de análise crítica. Durante estes anos, também frequenta os círculos culturais do ambiente germânico e conhece diretamente o expressionismo alemão ${ }^{6}$, e em especial a obra de Kaethe Kollwitz.

Em Berlim, não somente teve a oportunidade de atualizar-se intelectualmente, como também de acompanhar a efervescência cultural que acontecia naquela cidade. Como um dos grandes centros de modernização e de industrialização, Berlim vivia o contexto das reformas implantadas pela República de Weimar, levadas a cabo a fim de reestruturar o país, após a primeira grande guerra. Tais reformas foram sintomáticas das transformações culturais impulsionadas não só pelas políticas de modernização urbana e cultural, como também situadas no contexto de acirramento econômico entre as potências européias.

\subsection{A BERLIM DOS ANOS 1920}

A Berlim que Pedrosa freqüentou fervilhava de novidades advindas do progresso recente que invadia a vida da população e o nosso crítico pode acompanhar de perto e assimilar as novidades trazidas pela industrialização e modernização. A cidade assistia ao aumento do fluxo de carros e dos letreiros luminosos que anunciavam produtos e serviços. Nos círculos noturnos, a sociedade letrada freqüentava os polos culturais e depois se reuniam nos cafés para conversarem e conhecerem as novidades que despontavam. Ao redor das mesas dos restaurantes e cafés se discutiam sobre as últimas exposições, os últimos espetáculos, artigos relevantes e mesmo ali alguns esboçavam desenhos e croquis. $\mathrm{O}$ escritor Elias Canetti caracterizou o clima cultural de Berlim dos anos 1920 com as seguintes impressões:

\footnotetext{
${ }^{6}$ De acordo com a nomenclatura atribuída pela História da Arte, a obra de Kaethe Kollwitz é vista como pertencente ao expressionismo alemão. Muito embora exista em sua arte, a presença da deformação expressiva, no entanto, a artista move-se em um estilo muito peculiar de produção. Entre gravuras, xilogravuras e litos, a artista exprime suas convicções políticas e preocupações sociais. Não se engaja nas teorias estéticas dos grupos expressionistas "A Ponte" ou "O Cavaleiro Azul", uma vez que suas preocupações orientam-se mais no sentido do tema social, do que propriamente às pesquisas e experimentações estéticas da linguagem e de conteúdo subjetivo.
} 
Havia algo de áspero e corrosivo nessa atmosfera que excitava e vivificava. As pessoas precipitavam-se a tudo, não evitavam nada. A terrível coexistência de todas as coisas, o caos que se recebia como uma bofetada nos desenhos de George Grosz, isso tudo não era exagerado era em Berlim algo natural (..). ${ }^{7}$ (RICHARD, 1988, p.240)

Desde o início do século, Berlim despontava como o grande centro intelectual não só da Alemanha, mas também de toda Europa Oriental. Em contrapartida, Munique que outrora ocupava o prestígio de grande centro artístico, no início do século XX havia se encerrado nos entraves do academismo conservador, e não por menos, será eleita como o modelo cultural do regime nazista.

Em várias capitais da Europa que assistiam o mesmo ritmo de modernização, a grande concentração dos círculos literários e artísticos, giravam em tornos dos cafés, o que atribuía ao espaço da cidade um local importante para as trocas de investigações literárias, estéticas, e científicas de um modo geral e que caracterizavam a vida urbana como um espectro de idéias cosmopolitas e modernas. Os principais grupos de artistas da Alemanha, daquele período o Die Brücke (A ponte) e o Der Blaue Reiter (O cavaleiro azul), aglutinaram-se nestes espaços de convivência. Figuraram como movimentos importantes entre grupos de artistas do período, que fomentaram discussões e formulações sobre a nascente arte moderna no círculo germânico.

Não só em Berlim como em várias outras cidades da Alemanha, notava-se uma hostilização crescente ao academismo nas expressões artísticas. Em várias cidades emergiam e organizavam-se artistas voltados às linguagens modernas. Como exemplo desta situação, citamos o apoio das municipalidades a grupos como a Associação dos Abstratos de Hanôver; a Associação dos Artistas Plásticos Revolucionários em Dresden e a mais representativa Escola da Bauhaus em Weimar, que figurou como uma das mais importantes escolas do modernismo, sobretudo, relacionado ao design e arquitetura. Porém sua influência fora fortemente marcante nas artes plásticas, principalmente sobre o abstracionismo de Wassily Kandinsky e Paul Klee e sobre o movimento do neoplasticismo de Piet Mondrian e Theo Van Doesburg.

A modernização artística e cultural se direcionava no sentido de desviar-se de toda expressão que representasse culto ao passado e se interessava pelo desenvolvimento de novas vias artísticas que projetasse a Alemanha como um grande centro atualizado com sua época. Desde a belle-époque a Europa vivia um clima de efervescência cultural principalmente

\footnotetext{
7 Afirmação de Elias Canetti sobre o clima de Berlim e o âmbito de aceitação de novidades, citado in: RICHARD, Lionel. A República de Weimar 1919-1933. São Paulo: Cia das Letras, 1988. p. 240
} 
fomentado pelas políticas de modernização e remodelação das principais cidades e capitais. Os novos paradigmas do moderno trazidos pelos círculos literários e artísticos imprimiram às cidades, novas mentalidades principalmente no tocante a um novo estilo de vida e a um desprezo sistemático a todas as instâncias que estivessem atreladas ao passado e à tradição classicista.

As reformas urbanas e as nascentes relações sociais trazidas pelo contexto de industrialização e modernização das cidades imprimiram uma nova sensibilidade de sentir e de perceber o mundo. Tais percepções foram primeiramente apreendidas pela literatura seguidas pelas artes plásticas. A arquitetura tampouco ficou atrás. Ao acompanhar este período de modernização a Europa assistia ao estilo do art nouveau como uma introdução de novos padrões e materiais que tornassem a decoração mais leve e dinâmica. No entanto, este estilo ainda guardava muito do decorativismo e das estruturas arquitetônicas dos modelos classicizantes. Ainda nesta tentativa de um estilo mais sóbrio que acompanhasse o dinamismo da vida moderna, desenvolveu-se o art-déco como uma escola arquitetônica de estrutura monumental, mas com linhas simplificadas resumidas à suas funções específicas. Desenvolveu-se com uma decoração muito tímida e discreta que acompanhava as relações de funcionalismo das estruturas.

Mesmo com tais escolas, a arquitetura ainda não havia alcançado o desprendimento do universo clássico, tal como proposto pelo paradigma moderno, já assentado e assumido como um valor do progresso e da cultura. A grande renovação da linguagem arquitetônica passa a ser revelada com a escola da Bauhaus fundada em 1919 na República de Weimar por Walter Gropius que ao assumir a diretoria da Escola de Belas-Artes a remodela segundo princípios situados. A questão para a Bauhaus era assumir uma linguagem moderna que considerasse o elementar de cada forma associada à sua função e principalmente associar a produção artística à vida cotidiana. Tal aspiração foi responsável pelo desenvolvimento da Bauhaus como uma escola de design e voltada a uma decoração funcionalista e dinâmica, assim como o padrão moderno exigia.

Vários artistas de renome na época se agregaram à Bauhaus como um núcleo de estudos e ensino das questões artísticas, sobretudo, relacionadas à forma. Artistas, arquitetos e projetistas dos movimentos de vanguarda da Rússia e do leste europeu se dirigiram para esta escola após o recrudescimento da política soviética. Intelectuais como Kandinsky, El Lissitsky, Moholy-Nagy foram professores e mestres de novas experimentações estéticas. A instituição que fora edificada pelos princípios da Bauhaus, proporcionou uma revolução na maneira de conceber e de articular utilidade, funcionalidade e qualidade estética no mesmo 
projeto. Ancorados pelo clima de liberdade criativa e de experimentação, que artistas como Kandinsky e Theo Van Doesburg puderam encaminhar-se por pesquisas da estética abstrata, no estudo dos elementos estruturais da pintura, tais como a linha e a cor. Tais estudos produziram um forte impacto nas artes plásticas e introduziram novas linhas de pesquisas estéticas entre artistas do mundo inteiro.

As pesquisas levadas a cabo por Kandinsky, Paul Klee e Theo Van Doesburg trouxeram ao campo das artes plásticas novas informações e teorias, como as teses da gestalt que será consolidada como uma teoria importante para concepção e compreensão da estética abstrata. Neste contexto, situamos o interesse de Pedrosa pelas teses da psicologia da forma, pois não somente despontavam como novas teorias na área da psicologia experimental, como também se colocaram como um instrumental teórico fundamental para as pesquisas estéticas. É na Berlim da República de Weimar que tais pesquisas encontram suporte e é neste contexto de vanguardismo e experimentação que se situa a estada de Pedrosa em Berlim, como a configuração de uma época que o nosso crítico vai absorver.

\subsection{A ALEMANHA DE WEIMAR}

A Alemanha freqüentada por Pedrosa ainda compartilhava os desdobramentos decorrentes do desgaste político-econômico e da derrota sofrida após a primeira guerra. A década de 1920 fora atravessada em estado de penúria social e desestrutura econômica. $\mathrm{Na}$ concentração de esforços para combater a aliança inimiga, no período da guerra, os recursos e a mão de obra haviam sido dirigidos para o fronte de batalha. Faltavam recursos básicos como alimentos e roupas. A indústria vivia um desequilíbrio, uma vez que se havia destinado a produção dos bens à guerra, ainda faltavam recursos investidos em indústrias de base e produção de produtos básicos. A oferta de alimentos era racionada e não havia grande oferta de produtos nas lojas. Diante da escassez de recursos e até mesmo da subnutrição, não raras vezes pululavam epidemias de doenças como tuberculose, gripe, cólera e tifo que acometiam a muitos. A economia encontrava-se arrasada e carente de reformas urgentemente necessárias ${ }^{8}$.

\footnotetext{
${ }^{8}$ Lionel Richard em seu livro A República de Weimar, realiza um atento estudo e apresenta-nos uma descrição das condições da Alemanha após a $1^{\text {a }}$ guerra. Localiza a República de Weimar como uma tentativa de reestruturação econômica e social que desembocou em diversos desdobramentos relacionados à insatisfação
} 
A República de Weimar nasce com a incumbência de reestruturar a Alemanha e realizar os ajustes econômicos e políticos a fim de recolocar o país no cenário internacional. Dentre as várias reformas e medidas promovidas pela República as que diretamente nos interessam aqui são as dos setores educacionais, pois são reveladoras de nuances importantes para compreendermos o contexto universitário em que Pedrosa esteve inserido.

O governo de Weimar logrou instituir reformas no sistema educacional e pedagógico da Alemanha. No entanto, o embate entre as classes dominantes provocou uma reforma burocrática no sistema, o que na realidade não resultou em mudanças estruturais, pois manteve as bases conservadoras, e na prática o sistema de ensino, embora público, continuava privilégio das classes abastadas. Com relação ao ensino superior, o conservadorismo se manteve como força estrutural e as Universidades mantiveram suas posturas ideológicas e linhas de pensamento, conforme nos esclarece Lionel Richard:

Existiam diferenças entre as universidades, seguramente, bem como entre as disciplinas. A teologia protestante, o direito, os estudos de alemão eram geralmente considerados como de direita, enquanto a sociologia e a psicologia passavam a reputação de universidades liberais, enquanto em Berlim, de acordo com rumores inteiramente fundados, dominava a direita mais conservadora. (Ibid, p. 181)

Tal observação de Richard interessa à nossa abordagem histórica, pois é justamente no curso de Sociologia e Estética que Pedrosa fora estudar em 1926, ou seja, nas instituições entendidas como liberais, não radicalmente alinhadas às posturas da direita política. Embora o contexto cultural de Berlim fosse efervescente de novidades e andasse pari passu com as idéias vanguardistas modernas, o meio universitário alemão mantinha-se extremamente conservador e permissivamente racista. Havia, inclusive, uma cátedra para estudos racistas na Universidade e qualquer um que demonstrasse simpatia às idéias democráticas era sucintamente excluído do grupo e talvez afastado se não se retratasse ou contivesse suas opiniões pessoais. Muitos dos intelectuais eram simpatizantes de premissas conservadoras e antidemocráticas, pois viam nestas posturas, um caminho, a qualquer preço, para a reestruturação da Alemanha. A afirmativa de Martin Heidegger justificando sua própria

popular e ao sentimento nacional de revanchismo. Talvez seu maior sucesso tenha sido no campo cultural e no incentivo aos movimentos de vanguarda.

Peter Gay em seu livro sobre A Cultura de Weimar explicitará este mesmo pensamento, diz ele: "Quando pensamos em Weimar, pensamos em modernismo, em arte, literatura, pensamento; Pensamos em rebelião dos filhos contra os pais, dos dadaístas contra a arte, berlinenses contra os musculosos filisteus, libertinos contra moralistas retrógrados; pensamos em "A Ópera dos três vinténs", "O gabinete do Dr. Caligari", "A montanha mágica”, Bauhaus, Marlene Dietrich. E pensamos acima de tudo, nos exilados que exportaram a cultura de Weimar para todo o mundo". (p.11) 
atitude vale-nos como testemunho deste setor "Não era possível permitir que as universidades mergulhassem no caos, era preciso preservar o campo fechado da meditação estudiosa, era preciso ordem.” (Ibid, p.189). A reafirmação deste alinhamento das universidades com as idéias arregimentadas pelo nazismo, pode ser identificada no testemunho de Heinrich Mann que se manteve na oposição antifacista e se viu obrigado ao exílio na França. Dizia ele em um artigo de 1935, "Nas universidades, é possível que se esteja profundamente desapontado com o novo regime. Mas é impossível apagar ou esquecer que foram elas que lhe forneceram seus primeiros propagandistas. ” (Ibid, p. 190)

Assim o contexto de enrijecimento das posturas conservadoras vai sendo gradativamente construído e, quando da ascensão de Hitler, mais da metade dos universitários aderirão ao discurso nacionalista e racista dos nazistas, pois em essência, o clima de revanchismo o desejava. Os que se mantiveram na oposição a tais idéias, cerca de $20 \%$ do corpo docente, foram excluídos com suspensões, fechados em campos de concentração ou forçados a emigrar. Por este fato que grande parte da intelectualidade alemã irá migrar para outros países vizinhos, ou mesmo para Nova York, cidade que alcançará importância e destaque no cenário internacional, por abrigar e patrocinar a continuação das pesquisas destes intelectuais. Eles serão atraídos pelo clima de prosperidade e liberdade que o capitalismo em ascenção proporcionava.

A República de Weimar é conhecida pelo apoio que dispensou ao modernismo na arte, na literatura - ao pensamento moderno de uma forma geral, que investia na experimentação e na criatividade. No entanto, é parte do contexto pensarmos, sobretudo, "nos exilados que exportaram a cultura da de Weimar para todo o mundo".

\begin{abstract}
Os exilados ocupam um lugar de honra na história do mundo ocidental, grandes nomes realizaram suas maiores obras quando em residência forçada em solo estrangeiro, olhando com ódio e saudade para o país, que ficara para trás o seu próprio e que os havia rejeitado. Tais migrações forçadas de intelectuais ao longo da história não podem ser comparadas com o êxodo que começou no princípio de 1933, quando os Nazistas tomaram o controle da Alemanha; os exilados que Hitler fez constituíram a maior coleção de intelectuais, talentos e sábios transplantados que o mundo jamais viu. ${ }^{9}(\mathrm{GAY}, 1978$ p.11)
\end{abstract}

Peter Gay descreve com entusiasmo a importância que os intelectuais tiveram na construção da cultura do século XX. Vários nomes de intelectuais que exerceram um papel fundamental para o pensamento moderno foram rechaçados pela política nazista e tiveram que

\footnotetext{
${ }^{9}$ Ibid, p.11, parafraseado. Este contexto faz-se importante para assinalar o deslocamento do eixo de intelectuais da Europa para os Estados Unidos após a $2^{\mathrm{a}}$ guerra mundial.
} 
seguir com suas pesquisas no exílio. O autor cita Albert Einstein, Thomas Mann, Erwin Panofsky, Bertold Brecht, Walter Gropius, George Grosz, Wassily Kandinsky, Maz Reinhardt, Bruno Walter, Max Beckmann, Werner Jaeger, Wolfgang Köhler, Paul Tillich, Ernst Cassirer; foram exemplos de influências brilhantes que se deslocaram para o exílio. ${ }^{10}$

Em sua análise, Peter Gay fala de "Renascença de Weimar" como um momento curto, porém muito prolífero no campo das artes e das ciências. Também é rememorado como uma "época de ouro de Péricles" onde a reunião de intelectuais e a ânsia de modernização impulsionaram vários movimentos importantes para a história da cultura ocidental. Embora rechaçados pelo regime nazista, deslocam-se para outros eixos e vão desenvolver suas aspirações e projetos, ainda com mais veemência e anseios modernizantes.

Weimar simbolizava a síntese de uma nova sociabilidade após os traumas dos anteriores contextos de tensões belicistas que a Alemanha havia enfrentado. Na idealização de Weimar, existiam duas Alemanhas, a militarizada, agressiva, submissa à autoridade e excessivamente preocupada com a forma e a ordem, e a Alemanha do romantismo de Goethe, da poesia lírica, da filosofia humanista e do cosmopolitismo pacífico. O projeto de uma nova ordem social planejava tirar a Alemanha da condução agressiva e violenta de Bismark para uma condução humanista e cosmopolita.

O governo e as medidas da República de Weimar além de situar-se como uma tentativa de reestruturação dos setores econômico e político, almejava ainda uma "ventilação" das mentalidades ao patrocinar e apoiar iniciativas e instituições de pesquisas e produções que abraçassem o modernismo como foco, como uma configuração nova de idéias, de percepções e de relações urbanas e sociais. Esta iniciativa, porém, contrapôs-se ao conservadorismo do passado imperial que ainda permanecia vivo nas bases estruturais daquela sociedade e rechaçava toda e qualquer iniciativa modernista. Embora a proclamação da república tivesse sido um golpe disfarçado para ausentar a Casa Imperial alemã das responsabilidades da guerra, Weimar trouxe para dentro de suas realizações a incumbência de alinhar a Alemanha com as premissas da sociedade moderna. Onde para tanto, a arte e a cultura cumpriam um papel fundamental de retratar e traduzir as sensibilidades de um mundo em mudanças.

\footnotetext{
${ }^{10}$ Vários destes autores foram, inclusive, fundação teórica para as ideias de Mário Pedrosa, tais como Wolfgang Köhler, Wassily Kandinsky e Ernst Cassirer.
} 


\subsection{AS INFLUÊNCIAS TEÓRICAS E AS PESQUISAS ESTÉTICAS: OS ARTISTAS}

Quando em território europeu na década de 1920, Mário Pedrosa teve a oportunidade de frequentar as exposições do movimento expressionista alemão, como também, pôde acompanhar a movimentação artística deste cenário. Desta forma, presenciou o ambiente de debates e polêmicas em torno das propostas abstratas que circulavam pulsantemente nos circuitos artísticos. A formulação de uma arte que independia da representação para se constituir contagiava as pesquisas estéticas dos artistas e fomentava a desconfiança dos críticos que ainda buscavam um vocabulário analítico para descrevê-la.

Mário Pedrosa não somente frequentou estes círculos de debates, como também imergiu nos estudos científicos que embasavam estas novas formulações não-figurativas. De toda movimentação artística entorno da causa abstrata, porém, duas figuras artísticas serão referências fundamentais para a formação de uma base teórica para as pesquisas gestálticas e estéticas de Pedrosa, serão eles, Wassily Kandinsky e Piet Mondrian.

Sobre Kandinsky, Otília Arantes identifica a filiação do crítico:

O grande guia de Mário Pedrosa em toda essa discussão (sobre "sensibilizar a
inteligência") foi sem dúvida Kandinsky, a quem atribuía, como víamos, a
responsabilidade pela revelação, teórica e plástica, de todos os valores- ele teria
alcançado a feliz junção entre o imaginário e o pictórico: a aparente antinomia entre
forma e emotividade, expressão exterior e conteúdo interior, estaria resolvida pela
obediência à norma da "necessidade interior""11 (ARANTES, 1996, p. 24)

Foram as questões levantadas por teóricos abstratos como Kandinsky e Mondrian que impulsionaram Pedrosa a enveredar-se pela psicologia da forma, pois ao articularem a proposta de um espaço pictórico não figurativo, evidenciavam a necessidade de buscar a especificidade do objeto artístico e definir-lhe as estruturas epistemológicas. E nessa linha de pesquisa, Pedrosa vai buscar suporte teórico na psicologia da forma, ou seja, nos mesmos pressupostos que ampararam as pesquisas destes artistas. Ambos teorizaram um discurso próprio para suas investigações e desenvolveram suas linguagens a partir de teses racionalmente articuladas com teorias científicas. As duas linguagens artísticas, a abstrata de

\footnotetext{
${ }^{11}$ ARANTES, Otília. Prefácio: Mário Pedrosa, um capítulo brasileiro da Teoria da Abstração. In: PEDROSA, Mário. Forma e Percepção Estética: Textos escolhidos II (org. Otília Arantes). São Paulo, EDUSP, 1996. p.24. Este prefácio à obra reunida de Mário Pedrosa sobre este tema constitui-se como um dos poucos estudos de análise sobre as influências estéticas que conduziram o interesse do crítico às teorias da percepção.
} 
Kandinsky e a neoplasticista de Mondrian partem de teorias gestáticas para assimilarem em suas obras, as relações plásticas e dinâmicas do espaço bidimensional de seus quadros.

Quando o campo artístico viu-se liberto de sua função documentária, ou seja, de seu compromisso de imitação do real, a arte abre-se para novas perpectivas de experimentação da visualidade que pôde, desta maneira, ceder espaço à imaginação humana. É com este intuito, que os artistas recebendo a herança dos impressionistas e pós-impressionistas vão dissecar as realizações destes e encaminhar-se por uma via de investigação que possibilitou outras experiências visuais e perceptivas, quando "libertou" as formas e as cores da "objetivação empírica".

Pedrosa descreve com estusiasmo a nova linguagem plástica que decorre desta experimentação criativa:

O objeto que vinha sendo pouco a pouco deformado, alterado, reduzido, acaba transformando-se em mera abstração, até que os seus últimos vestígios desaparecem na arte pós-Mondrian. Kandinsky é, contudo, o primero que com a sua intuição genial, define a nova atitude, a nova função do artista diante do objeto: "de não mais perceber no objeto senão o poder de provocar a emoção." O objeto é o que provocava uma emoção. ${ }^{12}$ (PEDROSA, 2000, p.186)

As pesquisas estéticas desenvolvidas primeiramente por Kandinsky e encaminhadas por Mondrian consolidaram a transição da figuração para a liguagem abstrata e assinalaram não somente o esvaziamento dos preceitos renascentistas clássicos, como também levaram a arte moderna à algumas de suas últimas consequências. Estes artistas deram continuidade aos projetos geometrizantes e às tendências abstratas coloristas que vinham desde as aspirações artísticas dos movimentos do fim do século XIX, porém a especificidade e importância destes artistas reside não somente nas realizações plásticas que produziram, mas sobretudo nas teorias e postulações artísticas que consolidaram uma lógica a esta produção. Tanto Kandinsky, quanto Mondrian se envolverão com a linguagem abstrata como filosofia de vida, não somente desenvolvendo uma visão estetizada de arte, mas a vincularão a uma maneira de ver e compreender o mundo que os cercava. Ainda que Kandinsky represente um vínculo com a emoção e o "espiritual" e Mondrian um geometrismo racional, ambos se dedicaram à uma análise artística que transcendia a pura visualidade. Em ambas as pesquisas, os postulados da gestalt foram elementos fundamentais para articular uma relação semântica

\footnotetext{
${ }^{12}$ PEDROSA, Mário. Da abstração à figuração. In: Modernidade cá e lá (org. Otília Arantes). São Paulo: EDUSP, 2000. Nesta série de textos, Pedrosa faz um percurso pela abstração e discute seus conceitos, vertentes e principais mestres.
} 
entre as linhas e cores e a necessidade da arte inerente a cada ser humano, uma vez que as qualidades artísticas de uma obra estão na própria arte e não nos sentidos que atribuímos a ela.

\subsubsection{Kandinsky: Entre a razão e a emoção}

As pesquisas estéticas desenvolvidas por Kandinsky trouxeram à arte um novo axioma plástico, pois desafiavam o preceito da alusão temática para dedicar-se à uma relação sensível com a obra artística, onde o diálogo do espectador não seria mais com a significação do tema, mas sim como uma relação sinestésica com as cores e formas do espaço pictórico. Suas investigações estéticas não partiam da escalada cubista e também não tinham identificação com as aspirações construtivistas, mas foram definidas por ele, como uma "determinação" ou "necessidade interior" de exprimir-se e levar ao público suas intenções. Em seus estudos de História da Arte, Kandinsky já identificara nos coloristas italianos uma vívida expressão que tornava a comunicação da plástica bidimensional muito mais sensitiva e atraente e desde então, investia na cor como o elemento significante que poderia ocupar o lugar do tema e do conteúdo clássico.

Kandinsky formara-se em direito, mas não encontrava razão no exercício da magistratura. No entanto, tais estudos jurídicos o habilitaram para uma visibilidade clara de preceitos conceituais abstratos que lhe serviram como um suporte metodológico para o estudo e teorização das cores. As teorias do artista agregavam muito do idealismo alemão, principalmente da filosofia romântica de Fichte e Schelling, no tocante à maneira epistemológica da abordagem do significado. Partindo desta perspectiva, o significado do conteúdo não encontra-se em si mesmo, mas em relações arquetípicas e análises simbólicas que remetem à conteúdos culturais ancestrais. Nesta vertente encaminham-se tanto as premissas simbolistas, quanto as premissas "espirituais"13 que Kandinsky quis infundir à sua arte.

$\mathrm{O}$ artista estivera ligado ao circuito de artistas de Munique, porém, as frequentes críticas às suas obras que se distanciavam cada vez mais da figuração, levaram-no à demissão do cargo de Presidente da Nova Associação dos Artistas de Munique (NKVM). A partir desta

\footnotetext{
${ }^{13}$ Kandinsky usa o termo "espiritual" para referir-se ao conteúdo pulsante da obra de arte, podendo ser este a relação com a emoção, os sentimentos suscitados por cada elemento do conjunto pictórico da obra, como também um sentido de inclinação mística que envolve concepções teosóficas que também influenciaram as teorias coloristas do artista.
} 
ruptura, Kandinsky se associa a Franz Marc e lançam a publicação de seu grupo "Der Blaue Reiter", como um manifesto de suas propostas artísticas. Com o grupo, Kandinsky pôde desenvolver suas premissas com relação à uma arte que se detivesse nos elementos puros do espaço pictórico, neste sentido as experimentações estéticas não somente apontavam para uma crescente abstratização, como também o artista assim o desejava. Neste sentido, a abstração não foi uma consequência das pesquisas, mas era, desde o princípio, a causa das mesmas e uma intenção manifesta nos textos e livros publicados pelo artista. Sobre objetivos de seus escritos, ele escreve:

Os meus livros Do Espiritual na Arte e Der Blaue Reiter tinham por objetivo principal despertar as faculdades de viver o espiritual nas coisas materiais e abstratas que nos permitem viver experiências infinitas e necessárias para o futuro. $\mathrm{O}$ desejo de despertar esta faculdade geradora de alegrias nas pessoas que ainda não a tinham era o objetivo principal das duas publicações. (KANDINSKY, apud DÜCHTING, 2007, p.140)

As idéias de Kandinsky encaminhavam-se por orientações místicas, sublevadas sobretudo, pela filosofia romântica alemã e por idéias simbolistas do período. As composições abarcam reminicências figurativas, e qualidades sinestésicas a partir de elaborações chamadas de sonoridades das cores, que segundo as teses do artista atribuíam características e valores subjetivos às cores primárias e secundárias. As cores então, assumem os caracteres que a linguagem figurativa ocupara outrora. Associada às teses coloristas, outra constante nas pesquisas do artista será o problema da forma. Nesta investigação, Kandinsky disseca a estrutura da pintura e do desenho em seus componentes elementares - ponto, linha e superfície - para então, a partir de suas estruturas básicas reinaugurar uma imagética artística e resignificar as relações do espectador com a obra de arte. 


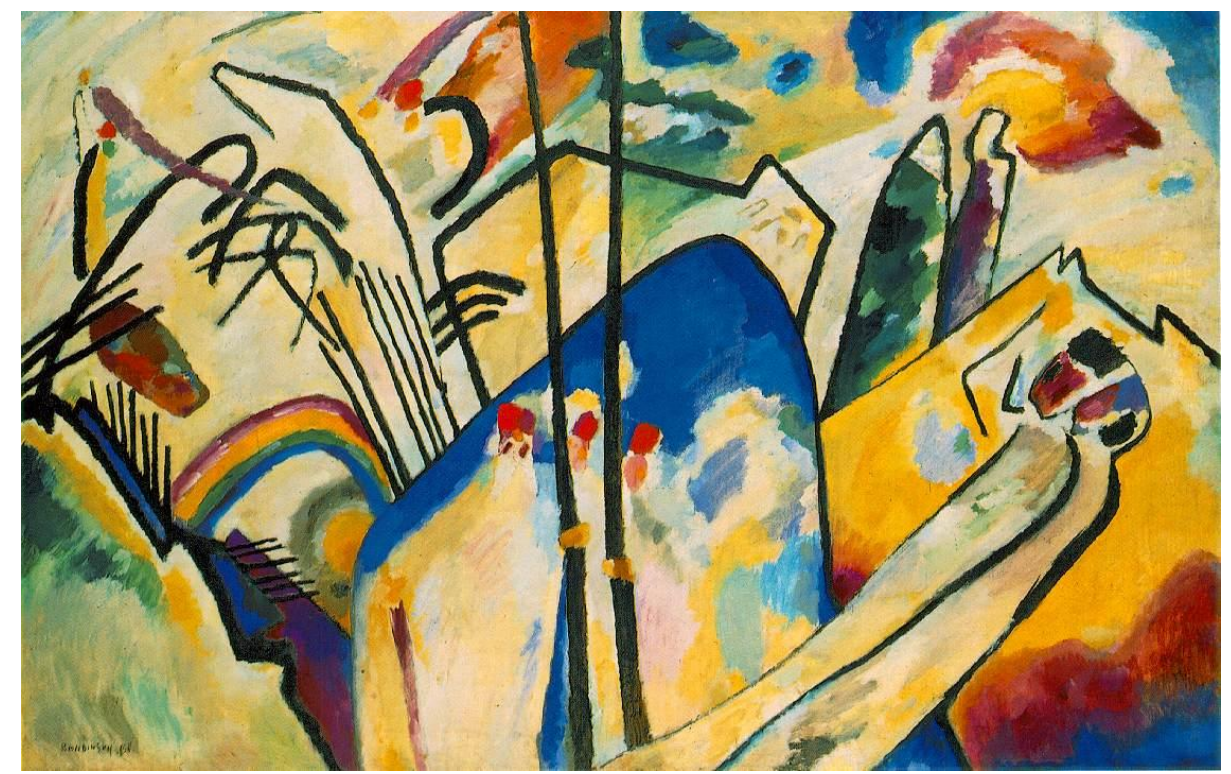

Figura 2- Wassily Kandinsky, Composição IV, 1911.

Fonte: DÜCHTING, Hajo. Kandinsky 1866-1944- A Revolução da Pintura. Cingapura: Taschen/ Paisagem, 2007.

Quando Kandinsky ingressa na Bauhaus, terá a oportunidade de reestruturar suas ideias a fim de agrega-las ao seu programa pedagógico e para tanto as complementa com as novas teses da psicologia da forma como um suporte científico para as relações que ele mesmo já vislumbrava como intrínsecas ao objeto artístico. As teorias e acepções da gestalt lhe farão aperfeiçoar seus estudos e atribuirão às suas composições um caracter mais equilibrado e racional, nas relações entre as cores e as formas, permitindo uma análise mais objetiva de seus critérios estéticos que outrora foram acusados como "espiritualismo puro" e "insignificantes". 14

Quando esteve na Bauhaus, Kandinsky revisou suas teorias a fim de sistemátizá-las para os cursos que ministrou. Os objetivos da Escola da Bauhaus em Weimar sob a direção de Walter Gropius iam ao encontro às experimentações estéticas e teóricas do artista russo e acolheram-no como um mestre importante para os cursos de pintura onde pôde desenvolver sua teoria das cores e das formas. O objetivo de Gropius era de unir as artes plásticas com as artes aplicadas, projeto este que encontrava eco e diálogo com a ideia mística de Kandinsky que acreditava em uma linguagem universal que unisse todas as artes. Desde seus estudos

\footnotetext{
${ }^{14}$ Referência à crítica de Nikolai Punin em Petrogrado na ocasião da Exposição da Pintura Moderna Russa, onde o crítico tece duras considerações sobre Kandinsky e que sinalizam o isolamento do artista com relação a uma ausência de critério científico para suas teorias. Escreveu o crítico: "Não sou o único a acreditar na seriedade absoluta e profunda deste pintor, e creio que é um homem cheio de talento. Não obstante, as criações artísticas de Kandinsky são insignificantes. Enquanto a sua obra se limita dentro do círculo do espiritualismo puro, ele transmite-nos certas sensações, mas assim que começa a falar na 'linguagem das coisas', torna-se não apenas um mau artesão (desenhador, pintor), como também num artista vulgar e mesmo medíocre." Citado in: DÜCHTING, Hajo. Kandinsky 1866-1944- A Revolução da Pintura. Cingapura: Taschen/ Paisagem, 2007. P.58
} 
com peças musicais, o artista estava convicto da existência de uma "correspondência interior" entre a obra artística e o espectador. Em Weimar, Kandinsky pôde estudar as teorias gestálticas e encontrar nas relações psicológicas da percepção a "correspondência interior" que vislumbrava em seus primeiros estudos. $\mathrm{Na}$ Bauhaus, pôde também experimentá-las com total liberdade em suas investigações plásticas, o que resultou em composições artísticas "espirituosas" e ao mesmo tempo equilibradas em suas relações internas entre tensões de linhas e cores.

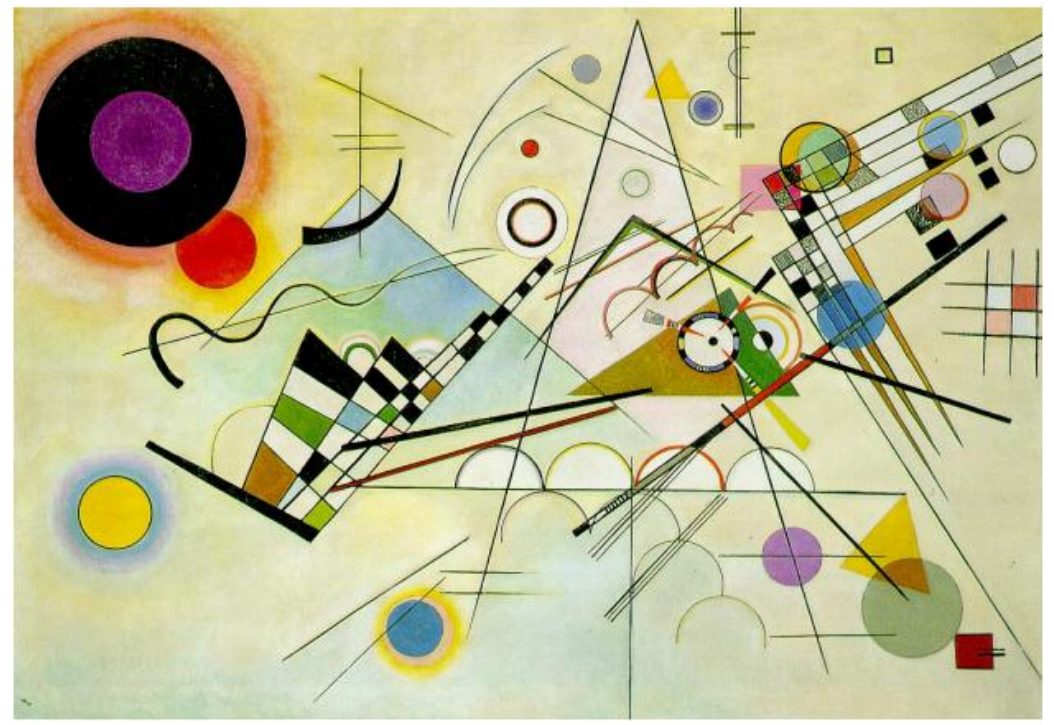

Figura 3: Wassily Kandinsky, Composição VIII, 1923.

Fonte: DÜCHTING, Hajo. Kandinsky 1866-1944- A Revolução da Pintura. Cingapura: Taschen/ Paisagem, 2007.

Com o ingresso de novos profissionais, a orientação da escola inclina-se para objetivos técnicos e funcionais com uma linha de pesquisa fortemente construtivista. Nesta nova fase, Kandinsky segue com suas pesquisas, mas encaminha-se para uma vertente racionalista com composições marcadas pelo rigor e pela lógica. Neste período, tem início a sua fase "fria" que investe na estruturação das tensões das formas no quadro e menos na energia e contrastes entre as cores. Com a mudança física da escola da Bauhaus para Dessau, Kandinsky pôde retomar as pesquisas estéticas relacionadas às abordagens das cores, sobretudo, devido ao convívio próximo com Paul Klee e com a retomada de aulas de pintura livre, que para além de análises da forma, poderiam experimentar composições e relações pictóricas. No entanto as orientações da Bauhaus sofrem novo recrudescimento quando Meyer assume a administração e objetiva centrá-la como uma escola de criação e designer funcional. Tal caracter funcionalista anulava o esteticismo e esvaziava as investigações e experimentações estéticas dos trabalhos de Kandinsky e de Klee. Ambos se desligam da instituição quando Mies Van 
der Rohe assume a direção e a transforma em uma pura Escola de Arquitetura. Pressionado pelas tensões políticas Kandinsky muda-se para Paris e encaminha-se para um vocabulário plástico mais próximo do surrealismo, abandonando o cientificismo de suas pesquisas. Os anos da Bauhaus atribuiram à produção do artista a edificação de uma linguagem abstrata e emotiva, mas baseada na razão e no equilíbrio formais, onde o aporte da psicologia da forma foi-lhe uma ferramenta importante para a análise e aprofundamento da obra artística, enquanto estrutura autônoma e enquanto objeto visual de seu espectador.

\subsubsection{Mondrian: $O$ construtivismo racional}

No âmbito das investigações abstratas, um contemporâneo das pesquisas de Kandinsky foi Piet Mondrian e muito embora as preocupações de ambos convergissem para alguns aspectos comuns, cada qual alcançou uma estética peculiar. A arte de Mondrian dedicou-se à uma busca similar pela estrutura básica do espaço pictórico, a partir de seus componentes essenciais, mas enveredou-se por uma abordagem extremante racionalizada, sem a energia emotiva do correspondente russo. Neste sentido, suas investigações levaram-no à uma dimensão bem mais estruturada e puramente geometrizante. As preocupações de Mondrian concentravam-se em estudos da forma que correspondessem à composições pictóricas rigorosamente abstratas. ${ }^{15}$

\footnotetext{
${ }^{15}$ Faz-se necessário estabelecer uma diferenciação entre arte abstrata e a estética desenvolvida por Mondrian. O artista filia-se a uma corrente artística não figurativa, que fora denominada por Van Doesburg de arte concreta. Embora toda produção artística seja uma abstração, uma vez que o artista abstrai os elementos da realidade e os recria em sua obra, a estética marcadamente abstrata refere-se à toda criação artística que transpõe a realidade para além da figuração e de seus elementos miméticos. Já a arte concreta é um estilo não figurativo atrelado às correntes racionalistas. Define-se como uma estética que suprime o objeto para desenvolver-se puramente no campo das ideias plásticas. Nesta linha, o artista concreto visa criar uma realidade objetiva, a partir da concretização de idéias plásticas em formas. Neste sentido, a arte concreta não se define especificamente como abstrata, uma vez que ela não parte de uma realidade abstraída. Assim, quanto mais distante da realidade a obra se colocar, mais concreta é a obra. Esta forma "concreta", no entanto, se relaciona à uma dimensão idealista platônica, que identifica as ideias como o plano essencial e completo. Extraído de documento de 1952 escrito por Vera Pacheco Jordão, que relata a entrevista da autora com Mário Pedrosa sobre a arte realizada naquele período. Afirma Pedrosa: "o caminho da arte moderna está no concretismo". Documento encontrado no acervo Mário Pedrosa na Fundação Biblioteca Nacional no Rio de Janeiro.
} 


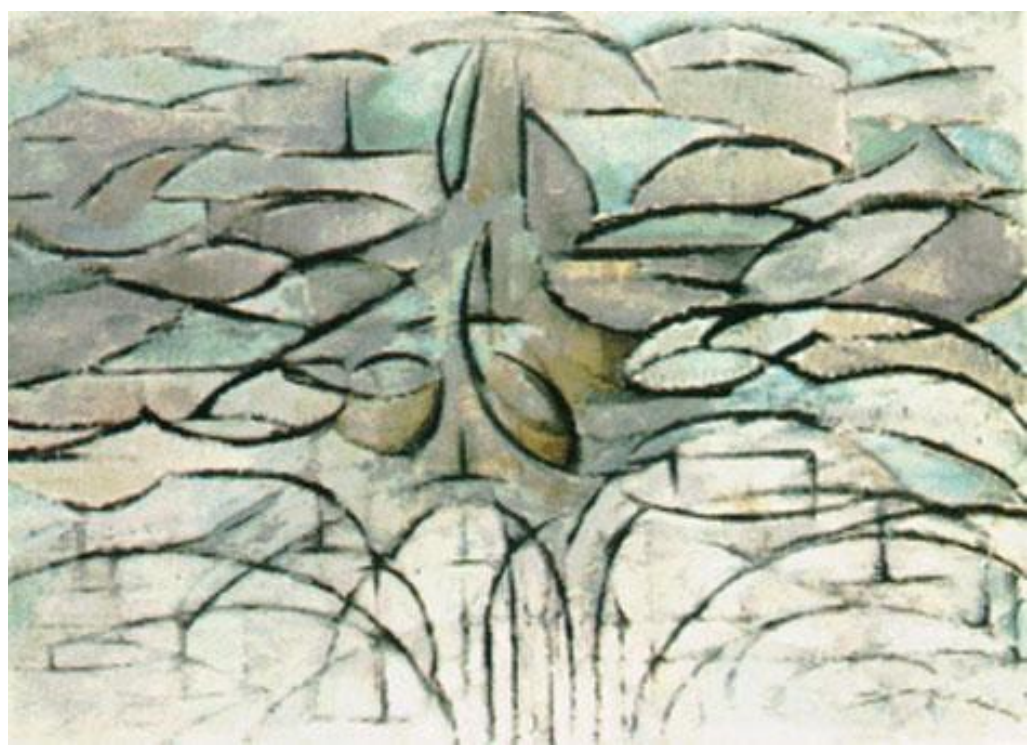

Figura 4: Piet Mondrian, Pommier en fleur, 1912.

Fonte: MALDONADO, Guitemie. Mondrian. Éditions Hazan, Paris, 2002.

Nos primeiros anos de seu percurso, o artista inicia suas pesquisas estéticas a partir das dissecações cubistas e vai gradativamente construindo seu vocabulário construtivista e revelando suas filiações teóricas e plásticas. Tem predileção pelo tema das árvores, no qual lhes extrai as linhas essenciais da forma e as linhas de forças de sua dinâmica orgânica para encontrar uma construção intelectual e plástica do ritmo e do equilíbrio, e muito embora suas obras fossem abstratizadas, o artista as nomeava com alusão aos elementos figurativos, o que ao longo de suas experimentações, tal prática será substituída pela nomenclatura elementar de composições, formas e cores. Sua estética foi largamente descrita e teorizada em seus escritos e principalmente nas publicações da revista De Stijl onde pode-se conhecer as premissas do neoplasticismo a partir das teses do próprio Mondrian.

Entre as técnicas compositivas neoplasticistas temos o uso restrito das cores primárias associadas às não cores branco, cinza e preto dispostas de maneira equilibrada sobre a planaridade bidimensional. As composições equilibravam grandes espaços vazios e superfícies pequenas e coloridas por meio de calculadas proporções. Atrelada às questões puramente formais somava-se intenções que estavam relacionadas à formação de uma nova sensibilidade e à formação de um outro ser humano. A assertiva do artista é clara quando remete-se às implicações sociais de sua obra:

O equilíbrio que perpassa a oposição, contrastante e neutralizadora, aniquila indivíduos enquanto personalidades particulares concebendo, assim, a sociedade 
futura como a real unidade. "A relação equilibrada é a mais pura representação da universalidade." ${ }^{, 16}$ (SEUPHOR, 1956, p.166-68 apud RICKEY, 2002, p.59-60)

Esta aspiração universal entrevê a utopia moderna de uma estética que tenha infiltração social e que de certa forma, altere as formas de perceber o mundo.Tais relações perceptivas que Piet Mondrian investigou e aplicou em sua arte, foram alvos do interesse e dos estudos de Mário Pedrosa, pois ao mesmo tempo em que o crítico abraça as mesmas aspirações racionais de uma arte universal que corroborasse para a formação de uma sociedade apta à uma nova sensibilidade, ele busca nas teses de Mondrian as fontes teóricas que fundamentavam suas investigações. ${ }^{17}$ Uma vez que "identificar a fonte pode às vezes explicar o caráter essencial de um influência", ao interessar-se pelas premissas do neoplasticismo, Pedrosa identifica a influência das teorias gestálticas no pensamento do artista holandês. Tais influências podem ser descritas pelas leituras realizadas pelo artista e pelo suporte teórico que Mondrian arregimentava. ${ }^{18}$

A natureza das pesquisas desenvolvidas por Mondrian e a constituição das teorias que ele publicou, evidenciam as preocupações com as questões da percepção e verificações da psicologia da forma aplicadas às suas experimentações estéticas. Nesta correlação, Pedrosa identifica a produção do artista como "uma arte difícil de apreensão numa aparência muito fácil de realização"(PEDROSA, 2000, p.193) pois o esquema geometrizante e a repetição seriada do mesmo padrão que formaram a estética conteudística do movimento neoplasticista, ocultam as intenções abstratizantes do tema, ou seja, tais padrões exibem somente a planificação das linhas essenciais provenientes do acúmulo de pesquisas sobre objetos reais e figurativos, mas não evidenciam seu percurso e suas fontes originais.

\footnotetext{
${ }^{16}$ As especificações das características essenciais da imagem para o neoplasticismo foram evidenciadas nas premissas desta escola.

${ }^{17}$ Mário Pedrosa interessou-se pelas questões desenvolvidas por Mondrian, sobretudo, seus estudos vinculados à psicologia da forma. Em um caderno de anotações, intitulado "Os artistas e a psicologia da forma" pertencente ao crítico encontramos uma série de estudos, fichamentos e reflexões sobre diversos autores que teorizaram sobre as teses da psicologia da forma e Piet Mondrian é citado várias vezes, seguido de suas declarações da revista Cercle et Carré. As cópias das páginas do caderno encontram-se em Anexo B; C e D, com as indicações destacadas.

${ }^{18}$ Em uma recente exposição realizada pelo Centre Pompidou em Paris no ano de 2010, sobre o movimento De Stijl e Mondrian, articulou-se um espaço que destacou as leituras teóricas de Mondrian e a importância que exerceram na composição do movimento neoplasticista. Seguem arrolados alguns dos títulos pesquisados pelo artista apresentados na citada exposição e notam-se literaturas relacionadas aos estudos da teoria da forma: BEHNE, Von Aldof. Von kunst zur gestaltung. Berlin, Biblioteca Nacional de France, 1925; MONDRIAN, Piet. Neue gestaltung. Munich, Bauhaus Bücher, n.5, 1925 (Neatherland Institut for art history); VAN DOESBURG,Theo. Bauhaus Bücher, n.6. Greendbigriffe der neuen gestaltung kunst- Fondement du nouveau art figurative; e citação de periódico datado de Julho de 1923 cujo título é "zur elementaren gestaltung"MNAM/Pompidou. Tal periódico circulava na Alemanha e na Áustria no período das investigações de Mondrian.
} 


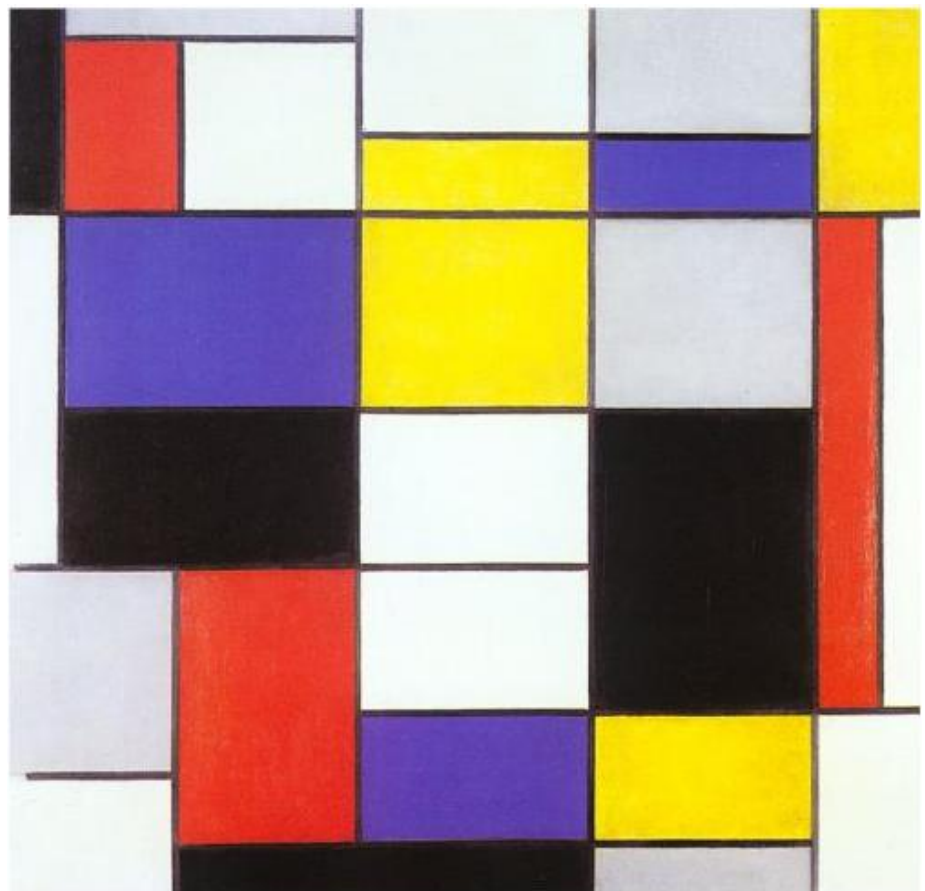

Figura 5: Piet Mondrian, Composição A, 1923.

Galleria Nazionale d'Arte Moderna e Contemporanea, Rome

Fonte: http://www.wikipaintings.org/en/piet-mondrian/composition-a-1923

Pedrosa identifica nas linhas essenciais de Mondrian uma força lírica que de certa forma fascina e seduz. Este poder de atração será definido como um ritmo cósmico, uma nomenclatura eufemística para se referir à filiação mística de Mondrian, pois tanto o artista russo, quanto o holandês, tiveram experiências espirituais com o teosofismo que de certa forma, marcaram as concepções de suas artes no sentido de elaborarem um significado subliminar como um deciframento das forças ocultas da natureza que vão muito mais além que a pura racionalização da arte moderna. No entanto, esta produção artística dedica-se mais à exploração das potencialidades da percepção visual e menos à uma caráter ilusionista que falseia uma realidade. As pesquisas de Mondrian apontam para a adoção das premissas da gestalt onde "os elementos das artes visuais tais como as linhas, as cores, as formas possuem sua própria força de expressão, independentemente da associação aos aspectos exteriores do mundo"19 e vale-se destes elementos intrínsecos à forma para coadunarem suas qualidades e propriedades latentes.

\footnotetext{
${ }^{19}$ Esta assertiva é uma das premissas do construtivismo apresentadas por Naum Gabo e que evidenciam a filiação às teorias da gestalt no tocante às qualidades intrínsecas das formas. Além desta tese, Gabo ainda assinala a concordância com a idéia da psicologia da forma de que a memória não participa da relação perceptiva entre sujeito e objeto. Diz ele: "A imagem não depende de experiências rememoradas, de acontecimentos, de objetos observados, de associações e sugestões, nem tampouco da projeção da experiência em formas evocativas. Não resulta de 'emoções relembradas tranquilamente', nem de fantasias, nem de gestos automáticos, nem de qualquer transe ou emanação do subconsciente." Citação encontrada em: RICKEY, George. Construtivismoorigens e evolução. São Paulo: Cosac \& Naify, 2002. P.58/59. Estas idéias sobre as teses da psicologia da forma
} 
Por estas abordagens, Pedrosa fará diversas referências à Mondrian e suas teses quando se detém aos estudos de textos gestálticos. Nas diversas conferências que assistiu sobre o assunto, realiza constantes anotações e citações de teóricos da psicologia da forma, teóricos das artes e textos de artistas. É possível que Pedrosa tenha frequentado as exposições de Mondrian na Europa na década de 1920, como também pode ter visitado e acompanhado as exposições nos EUA na década de 1930, período que tanto Mondrian, quanto Pedrosa encontravam-se em solo americano, devido às perseguições políticas do contexto abrasivo do entre guerras. Em 1945 o MOMa de Nova York realizou uma grande retrospectiva sobre a obra do mestre holandês e para muitas pessoas, tanto artistas, especialistas ou mesmo espectadores comuns, fora uma das raras oportunidades de conhecer as investigações e premissas estéticas deste artista.

\subsection{A DÉCADA DE 1930: A CONJUGAÇÃO ENTRE POLÍTICA E ARTE}

Durante o período que esteve na Alemanha nos anos 1920, Pedrosa se dedicou aos estudos destes teóricos e acompanhou de perto as exposições e debates sobre as abordagens não figurativas da arte, sobretudo na pintura. $\mathrm{O}$ crítico estudou as teorias gestálticas por via dos teóricos alemães e pode beber da fonte das novas idéias que circulavam e que articulavam racionalmente uma teoria científica que buscava compreender os mecanismos de percepção e reação diante dos fenômenos a que são expostos.

Mesmo centrado nas questões estéticas e conceituais, o crítico não abandona a militância política. Ainda em Berlim, Pedrosa tem contato com a dissidência de oposição da esquerda russa, liderada por Trotsky e Zinoviev. Pouco tempo depois Pedrosa liga-se ao movimento de fundação do Partido trotskista na Alemanha. Após sua estada de estudos e tramitações políticas na Alemanha, Mário Pedrosa volta ao Brasil em 1929. Segue com suas atividades políticas da esquerda bolchevista, e se dedica a uma coluna em $O$ Jornal, no Rio de janeiro. Mantém-se na militância política e retoma as discussões em torno da fissura do Partido Comunista na Alemanha. Como simpatizante trotskista, Pedrosa acaba por desvincular-se do PCB- Partido Comunista Brasileiro- e juntamente com colegas que partilhavam das mesmas opiniões fundam o grupo Bolchevique Lênin, a vertente trotskista 
brasileira, nos moldes do bolchevismo alemão, e intensificam as atividades ligadas à ideologia da esquerda radical no Brasil. Por atividade deste grupo lança-se o jornal A Luta de Classes que noticia as atividades e debates do meio trotskista ao redor do mundo.

O contexto das grandes guerras e principalmente da Revolução Russa de 1917 marcou a iminência de alinhamentos partidários, aos quais reverberaram atitudes e ações de intrínsecas convicções ideológicas. Mário Pedrosa acompanhou de perto as agitações políticas que assolavam tanto os centros do poder quanto também se estendiam à periferia do mundo capitalista. Fora um intelectual engajado que participou ativamente das diretrizes ideológicas de esquerda, ao defender as vertentes mais radicais.

Durante toda a década de 1930, Pedrosa milita na ala trotskista no Brasil e participa do secretariado da IV internacional ativamente. Entre 1929 e 1939, Pedrosa se dedica à causa revolucionária e participa na organização e divulgação panfletária da oposição comunista ao modelo e funcionamento sistemático do capital, e de seus desdobramentos políticos e econômicos. Assume-se militantemente pela causa. Funda a UNITAS, uma Editora que publicava no Brasil, escritos e textos comunistas. Neste empreendimento, Pedrosa traduziu e prefaciou vários ensaios de Trotsky, a fim de divulgá-los. Participou da organização de protestos e envolveu-se na candidatura simbólica de Luís Carlos Prestes à presidência. Por atuar veementemente nestas atividades, Pedrosa é alvo da investigação policial, cerceado principalmente pelo clima de caça aos comunistas, norteado pela conjuntura do governo Vargas e do alinhamento deste com a direita integralista. Neste panorama político, os ânimos se exaltavam impregnados pelo partidarismo radical, os quais causavam o enfrentamento entre as posturas de esquerda e de direita e tendo como resposta política dos governos autoritários em exercício, as medidas de contenção da oposição através do cerceamento ideológico e do encarceramento de figuras de destaque.

O proselitismo do discurso de Pedrosa não era retórico e se dirigia a uma atuação militante que verdadeiramente trabalhasse em prol de que a revolução se afigurasse possível. Como militante trotskista de atuação intensa no partido e nas ações de divulgação de escritos marxistas, Pedrosa era vigiado de perto pela polícia política brasileira por realizar grande atividade no meio trotskista, atividade esta que era entendida pela polícia como subversiva e ameaçadora à ordem e razão do estado brasileiro, de diretrizes claramente fascistas. Assim sendo, Pedrosa e sua futura esposa Mary Houston são fichados e presos em 1932. 


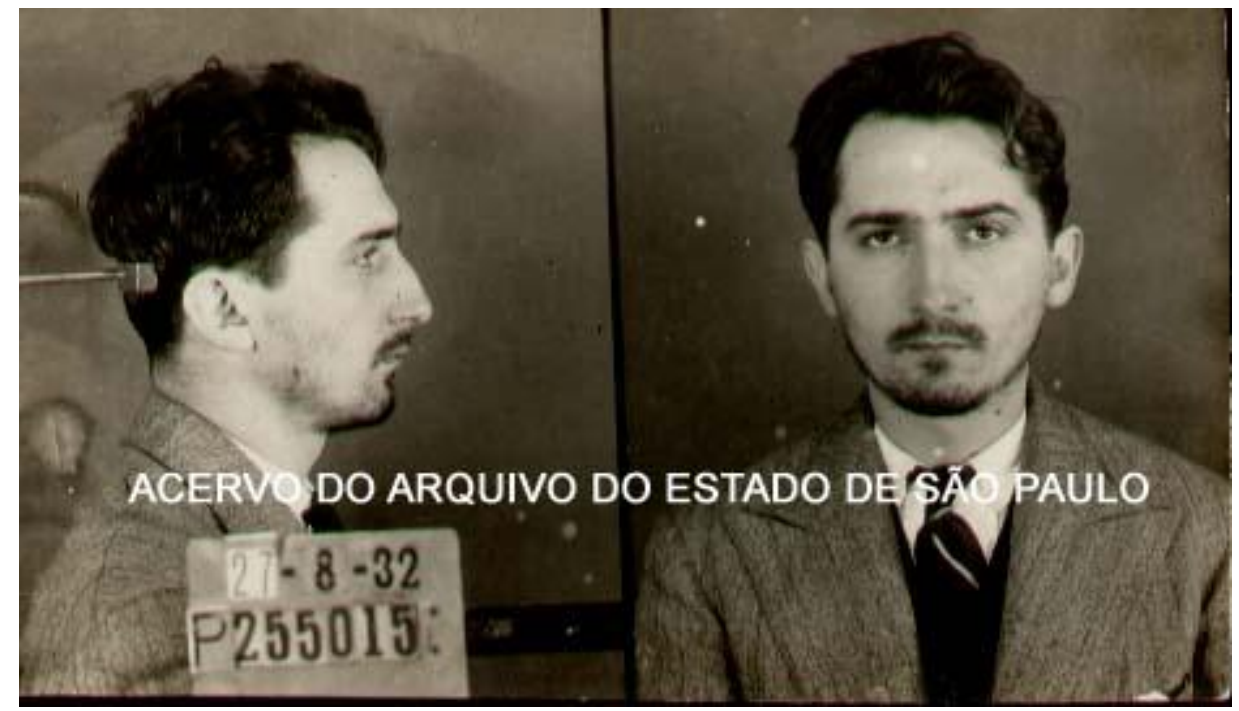

Figura 6: Registro de Mário Pedrosa, (perfil e frente) quando dada sua entrada como fichado pelo D.E.O.P.S. Prontuário n ${ }^{\circ}$ 2.030- /27-08-1932

Fonte: Arquivo do Estado de São Paulo

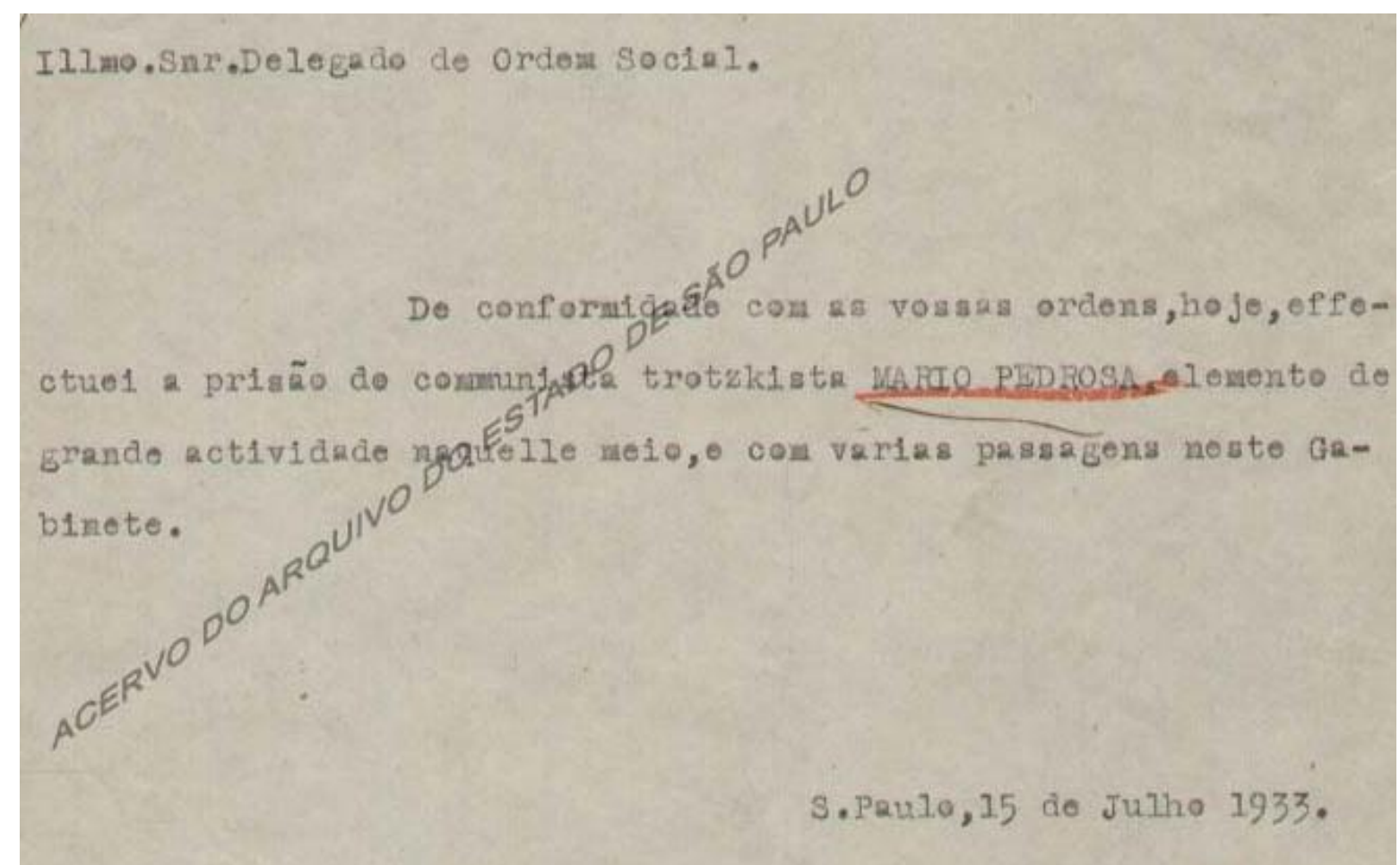

Figura 7: Documento com o comunicado de prisão de Mário Pedrosa por suas atividades comunistas, entendidas então como subversivas à ordem. Prontuário n ${ }^{\circ}$.030/ 15-07-1933.

Fonte: Arquivo do Estado de São Paulo

Não há como falar da produção critica de Pedrosa, sem citar sua vinculação com suas convicções políticas. Esta preocupação permeou os trabalhos do crítico por todo seu percurso intelectual e não lhe foi uma questão de modismo temático, pelo contrário, pois a arte representava para ele um caminho onde poderia projetar a revolução das sensibilidades a fim 
de "formar" os cidadãos que estariam preparados para a constituição da sociedade esclarecida que tomaria parte na luta pela revolução permanente pelo socialismo. Marcelo Mari, estudioso da relação entre estética e política em Pedrosa, discute o processo pelo qual o crítico transita de uma atuação politicamente militante a uma atuação mais criticamente militante no campo das artes. Diz ele:

Embora Pedrosa tivesse sempre em mente o processo final de síntese entre arte e revolução social, processou-se uma mudança em seu posicionamento. Este derivou não do afastamento premeditado da política para a dedicação exclusiva à atividade de crítica de arte, mas de um ajuste necessário de Pedrosa para articular de outro modo arte e política, a fim de que os augúrios do campo artístico se concretizassem. (MARI, 2006)

Será neste contexto de efervescente atuação política e de convictas posições teóricas que Mário Pedrosa estreia no campo da crítica de arte com uma conferência sobre a obra da artista alemã Kaethe Kollwitz. Seu discurso vislumbra a potencialidade do recurso artístico para atrelar-se a uma causa. A conferência sobre a exposição de Kaethe Kollwitz proferida em junho de 1933 no Clube dos Artistas Modernos em São Paulo, configurou-se como um espaço de reflexão crítica na qual Pedrosa evidencia a consistência teórica de suas posturas políticas, em uma elaborada simbiose entre história, arte, política e perspectiva revolucionária. Este empreendimento analítico é revelador das intenções do crítico e de uma constante preocupação com o viés político, na qual a arte figura como um elemento libertário.

O teor político e militante presente na crítica de Pedrosa sobre a artista alemã Kaethe Kollwitz, é reflexo do próprio contexto no qual fora escrito, um momento de intensa convulsão política e social que fomentou não somente a indignação da oposição contra as atitudes arbitrárias do poder instituído, como também fomentou uma produção artística que materializou as angústias e temores que permeavam as relações sociais e emocionais destas convulsionadas realidades.

Em um contexto de guerras e de uma nova ordem social baseada na exploração capitalista, a arte se coloca diante de parâmetros que se querem definidos: ou encaminha-se para uma linha de caráter revolucionário, naquela que faria a "revolução cultural" em prol da liberdade, ou engendra-se na cooptação do sistema e lhe representa em sua dimensão simbólica. As realizações artísticas e culturais destas décadas representaram este embate e propuseram questionamentos às instâncias estéticas e críticas. A quebra de paradigmas foi um estandarte para esta geração que atuou militantemente em todos os aspectos da sociedade e da política. E na arte não fora diferente. Engendrada pelo contexto de uma organização social em 
derrocada, o discurso artístico assumiu diversos questionamentos que tocaram questões formais e conceituais como uma via de extravasamento das inquietações de uma realidade em crise.

Neste contexto, Giulio Carlo Argan atribui novos parâmetros para a crítica que incidirá sobre esta produção artística:

A crítica torna-se assim intervenção ativa numa situação social e política, porque o desaparecimento da finalidade estética, já associada a todos os atos do trabalho e da existência, compromete a dignidade e a liberdade dos trabalhadores, reduzidos a meros instrumentos e submetidos à exploração dos empresários. (ARGAN, 1995, p.136)

Estas idéias que expressam inconformismo e que propõem a tomada de uma atitude combativa contra o status quo, encontram paralelos nas posturas políticas de Mário Pedrosa e que igualmente se desdobra em sua atuação crítica. Ao defender uma arte e um discurso crítico engajado e militante, entende a produção artística como um instrumento para a libertação do homem, contra as amarras econômicas e políticas e que num plano superior dessem respaldo para a capacidade criativa do homem, extrapolando formas, conceitos e espaços. Ao longo da trajetória crítica de Pedrosa, assinala-se que em seu vocabulário crítico circulam diferentes premissas estéticas atreladas a outras linguagens para além daquele modernismo social dos anos de 1920 e 30, no entanto, as suas expectativas projetadas na arte seguirão as mesmas.

Dado o contexto em que se encontravam diante da vertente fascista brasileira que se apresentava sob a forma de integralismo, a política e seus desdobramentos despontavam como uma preocupação mais eminente que os debates conceituais e estéticos da arte, ou como diria Pedrosa "as polêmicas deixavam de ser artísticas para se tornarem politicas." ${ }^{20}$ (PEDROSA, 1986, p.278) Porém o que ele de fato defendia, era uma arte engajada e que refletisse sobre as questões da política e sociedade, ou seja, que unisse o estético ao urgente, "o ambiente de alta tensão social e de crise institucional não permitia mais as explosões puramente estéticas ou culturais da Semana." 21

\footnotetext{
${ }^{20}$ PEDROSA, Mário. "Entre a semana e as Bienais" In: Mundo, Homem, arte em crise (org. Aracy Amaral). São Paulo: Perspectiva, 1986, p. 278. Neste texto de 1970, Pedrosa faz uma retrospectiva histórica sobre a formação das instituições brasileiras, das produções e dos artistas brasileiros que marcaram a modernização das artes no Brasil. Em sua reflexão, Pedrosa caracteriza a década de 1930 como um período seriamente marcado pelo autoritarismo do Estado Novo que vigiava e controlava a circulação das idéias.

${ }^{21}$ Pedrosa remete-se à euforia das realizações da Semana de 1922 realizada em São Paulo e de seus desdobramentos culturais.
} 
Neste contexto de efervescência cultural e de acaloradas discussões políticas que a apresentação da conferência de Mário Pedrosa sobre a gravurista alemã Kaethe Kollwitz, assume tamanha importância e destaque no cenário crítico brasileiro. Intitulada originalmente como "Kaethe Kollwitz e o seu modo vermelho de perceber a vida" teve o título alterado para "As Tendências sociais na arte e Kaethe Kollwitz", quando de sua posterior publicação no hebdomadário O Homem Livre, em julho de 1933, um periódico paulista de orientação marxista. O novo título evidenciava uma vertente social na crítica de Pedrosa e correspondia ao discurso crítico e político que se queria engendrar.

Nesta comunicação, Pedrosa tece apreciações estéticas sobre a obra da artista alemã conjugada a um lúcido e apaixonado estudo sobre a função social da arte com premissas e argumentos marcadamente marxistas. Teria sido esta crítica "o primeiro estudo propriamente marxista da arte entre nós (e creio que era uma novidade em toda América então)",22( ALAMBERT, 2005, p.141). Neste texto Pedrosa não se atém somente a discutir a obra da artista alemã, antes o crítico remonta ao próprio percurso da arte e da função social que a arte desempenhou ao longo dos séculos. Para tal empreendimento, Pedrosa vale-se de um discurso embasado no materialismo histórico o que não esconde suas filiações teóricas. É justamente na articulação conceitual de teor marcadamente marxista que reside a novidade desta crítica.

Não teria sido este o primeiro contato de Pedrosa com a artista alemã. Na década de 1920 quando esteve a serviço do partido comunista na Alemanha já havia conhecido e se embebido com as concepções estéticas e temáticas de Kollwitz. As aspirações da artista vão ao encontro às do crítico e desvendam à Pedrosa uma potencialidade que a arte assumiria no contexto da revolução social permanente, ou seja, de denunciar as atrocidades e tensões promovidas pelo modelo capitalista exploratório e opressor. A arte seria entendida nesta perspectiva, como um recurso capaz de falar às mentes e sensações, atuando como poderoso instrumento contra a alienação e evidenciando os entraves de um modelo que deveria ser superado. Pedrosa alinha-se às concepções críticas de Argan quando este caracteriza uma arte engajada:

A Arte da resistência teve uma linha programática; refletiu um estado de ânimo de revolta moral e civil, o desespero de uma condição humana que fazia de cada indivíduo um refém e uma vítima. (ARGAN, 1995,p. 45)

${ }^{22}$ ALAMBERT, Francisco. "Milliet- Pedrosa: Aproximações rumo à ação socializadora da arte" In: GONÇALVES, Lisbeth Rebollo. Sérgio Milliet, 100 Anos: Trajetória, Crítica de Arte e Ação Cultural. São Paulo: ABCA/Imprensa Oficial, 2005. p.141. 
A partir de uma perspectiva crítica inovadora, Pedrosa traça em seu texto sobre Kollwitz, um percurso sociológico e historiográfico explorando os modos de produção e o materialismo histórico dos diversos ciclos econômicos e culturais da história da humanidade, associando as técnicas de que dispuseram as sociedades, com a capacidade de elaboração de sua expressão artística. Pedrosa articula um discurso sociológico e erudito a fim de evidenciar as tendências sociais da arte, e somente depois de fazê-lo, situa a produção de Kaethe Kollwitz, como se a artista fosse a melhor e mais acabada representação de uma arte social.

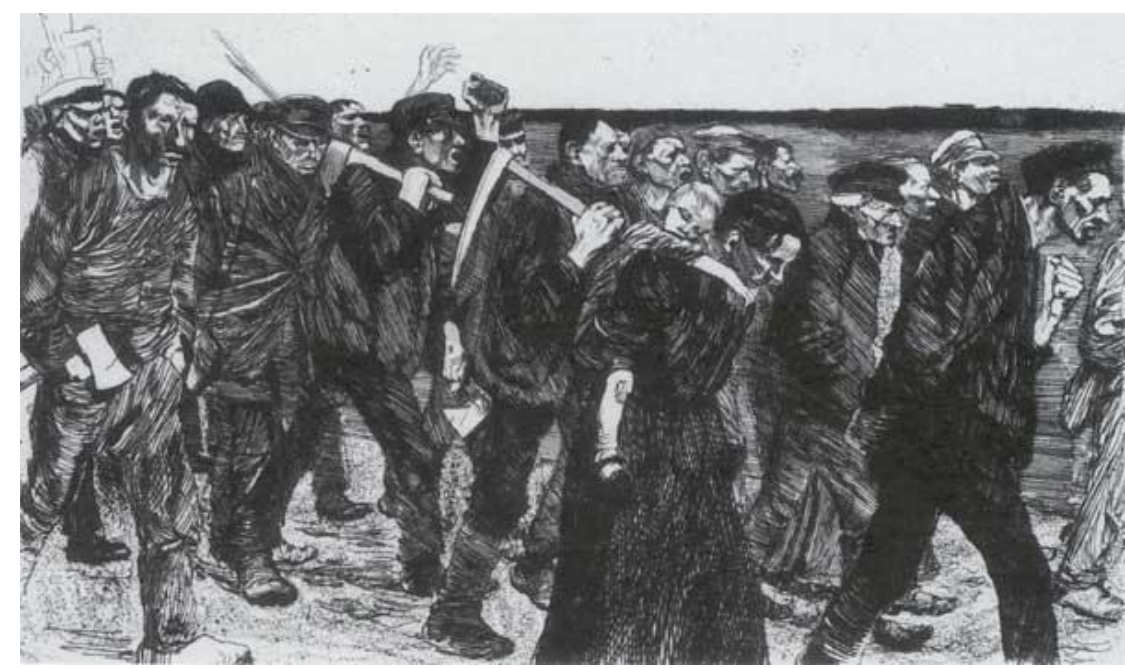

Figura 8: Kaethe Kollwitz, A Revolta dos Tecelões, 1897.

Fonte: http://www.dhm.de/ausstellungen/streik/detailansichten/kunst detail25.html

Para Pedrosa, a arte não seria constructo decorativo e contemplativo para uma burguesia esnobe, mas antes de tudo uma arma de denúncia das mazelas da sociedade, e projetava em sua crítica uma possibilidade de problematização social e não um usufruto estético pacificador. O crítico defende uma arte engajada onde "Não lhe sobram momentos para ensarilhar as armas e entregar-se aos prazeres da contemplação e da imaginação gratuita. "23(PEDROSA, 1949,p.33) Se o contexto é de guerra, a arte é arma do proletariado, e como tal deve ser ácida e incisiva, não deve agradar, mas antes denunciar e incomodar. Assim como a questão social é urgente, mas urgente ainda é a necessidade da arte de subtrair-se dos meios burgueses e assumir sua função política declarada. Esse viés político era para Pedrosa um impulso:

Como a obra, também a crítica não é para Mário um mero registro, ele sentia-se por demais comprometido com a arte para não tomar partido. Mas o que ele buscava nela, para além de todos os ismos, não era outra coisa do que aquela necessidade a

\footnotetext{
${ }^{23}$ PEDROSA, Mário. “As Tendências Sociais na Arte e Kaethe Kollwitz”, In: Arte, Necessidade Vital. Rio de Janeiro: Livraria Editora da Casa do Estudante do Brasil, 1949. p. 33
} 
que nos referíamos- sua verdade interna. Ele estava sempre pronto a descobrir aqueles raros instantes em que 'a própria junção denotativa da representação elevase no plano da fusão criativa em substância universal'. ${ }^{24}$ (ARANTES, 1982,p.44-45)

É deste modo que Mário Pedrosa confronta-se com a arte que contempla e sobre ela faz sua crítica, como uma necessidade interior que precisa ser compartilhada. A orientação ideológica e crítica de Pedrosa sintetizavam uma maneira de pensar a arte numa dimensão social que somaria parte a um projeto de ação revolucionária e pedagógica presente contundentemente em suas ações. A arte deveria então realocar-se na educação das sensibilidades a fim de um dia lograr alcançar a revolução social e constituir uma sociedade mais humana e igualitária. Se isto era uma utopia, Pedrosa buscou lucidamente traduzi-la em sua crítica, pois ao mesmo tempo em que a obra de Kaethe Kollwitz é reveladora de uma face oprimida da sociedade, a crítica de Pedrosa é um chamado a uma tomada de consciência de nossas próprias realidades e reavaliação de nossa relação com a arte. Não se passa incólume ao teor político deste discurso, seja para concordar ou discordar, o autor convida seu leitor a uma reflexão situada diante de sua própria condição de alienação.

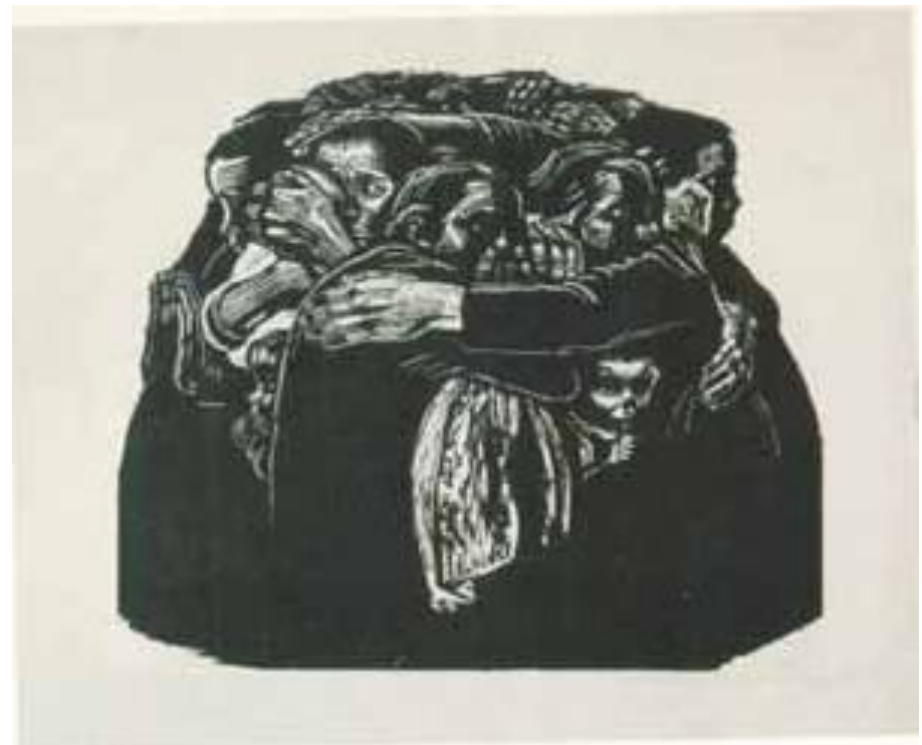

Figura 9: Kaethe Kollwitz, As Mães, 1922/23. Fonte: Coleção MAC-USP.

Desde seu início, a crítica de Pedrosa agregou novas vertentes de interpretação e análise na produção crítica brasileira. Como um crítico politizado, engajado e atualizado com as novas questões estéticas, procurou estabelecer diálogos com teses importantes que se lançavam no debate internacional. Embora se vislumbrem questionamentos sobre suas

\footnotetext{
${ }^{24}$ ARANTES, Otília B. F. Mário Pedrosa, Trajetória Crítica. Módulo, RJ Avenir, n 69. p.44-45,1982.
} 
polêmicas posturas e estratégias de ação, a atualidade e vigor de sua crítica evidenciam uma maneira peculiar de entender a arte e a cultura vinculadas a um compromisso social de aproximar a arte do público e fornecer-lhe instrumentos teóricos para apreciação e fruição estética da obra como uma necessidade sensível. Algumas destas premissas estavam já no discurso e nas teorias de Kandinsky, de quem Pedrosa será profundo admirador e até mesmo em certa medida "discípulo," pois além de entender a arte como expressão e necessidade interior do humano, ainda tal expressão não deveria ser entregue ao puro subjetivismo, mas entretanto, ser expressa a partir de idéias racionalmente organizadas por pressupostos lucidamente estabelecidos.

Com o golpe do Estado Novo em 1937, Pedrosa é processado pelo estado brasileiro e foge para Paris utilizando o passaporte de um amigo. Em Paris trabalha pela fundação da IV Internacional Comunista e após a realização do Congresso, Mário vai para os Estados Unidos a fim de secretariar a Internacional neste país. Instalado em Nova York trabalha no Museu de Arte Moderna e no escritório do coordenador de assuntos interamericanos. Em 1939, juntamente com sua esposa muda-se para Washington e passa a trabalhar no Boletim da União Panamericana como redator para língua portuguesa. Paralelo a esta atividade, o crítico segue com sua militância junto ao Trotskismo. Quando o secretariado da IV Internacional é revisto, Mário é excluído. Este fato faz com que Pedrosa reavalie suas posturas políticas, o que o leva ao desvencilhamento do bolchevismo. Pedrosa afasta-se das atividades burocráticas do partido, contudo, suas convicções ideológicas permanecem as mesmas e inclusive o seguirão por toda vida e influenciarão suas atitudes e atuação crítica. Seja o Pedrosa da crítica sobre Kaethe Kollwitz, seja o crítico do texto sobre Alexander Calder, ou como teórico estimulador do neoconcretismo, as suas posturas e convicções políticas estarão no horizonte de seu pensamento.

Com este relativo afastamento da militância política, Pedrosa concentrará suas energias no estudo e aprofundamento das questões artísticas. À maneira de como fizera na Alemanha, durante o tempo que esteve em Nova York se dedicou a assistir aulas e acompanhar cursos de professores, que porventura, seriam os mesmos, ou discípulos daqueles mestres e teóricos alemães. Conforme assinalado anteriormente, quando da ascensão do partido Nacional Socialista na Alemanha que enrijeceu as políticas de controle ideológico nas universidades, um grande contingente de professores universitários, literatos, artistas, arquitetos, designers migraram para os Estados Unidos em busca de tranquilidade política e apoio institucional para suas pesquisas e projetos. 
Assinalado este contexto, compreendemos o fato de Pedrosa ter retomado os estudos sobre as teses da Gestalt em Nova York.

\title{
1.7 NOVA YORK: RETOMADA DE PESQUISAS
}

A década de 1920 fora de um período de modernização em todas as grandes capitais do mundo ocidental. No entanto a cidade de Nova York, desde o começo do século já convivia com uma modernização vertiginosa, abrigando os primeiros arranha-céus e um tráfego intenso de automóveis em suas vias. Nos anos 30, a cidade já era a grande referência do mundo moderno e abrigava os grandes símbolos econômicos e políticos de envergadura mundial. A economia americana crescia e agregava novas tecnologias ao cotidiano comum e pouco a pouco formatava uma nova forma de viver, segundo o estilo de vida americano. Mesmo a crise de 1929 tendo gerado uma recessão na economia norteamericana e impactado o ritmo de crescimento da produção industrial, Nova York se destacava como um fulcro no sistema capitalista em franca ascenção. Embora representasse a modernidade e simbolizasse o consumo, no campo das artes e da cultura, porém, o grande centro ainda era Paris.

Clement Greenberg em seu relato sobre Nova York nos anos 1930 identifica a imaturidade da cidade em relação aos aparatos e equipamentos especializados em artes, assim como os que existiam na cidade luz, o crítico descreve:

\begin{abstract}
Muitos dos artistas que eu conhecia liam as revistas de arte de Nova York, mas só por um respeito supersticioso para com o papel impresso que eles compartilhavam com a maioria das outras pessoas; não levavam realmente a sério o que liam. As publicações de arte que vinham da França, sobretudo os Cahiers D'Art, eram uma outra história; estas publicações informavam sobre as últimas produções de Paris, o único lugar que realmente importava. ${ }^{25}$ (GREENBERG, 1996, p.236)
\end{abstract}

Este relato é testemunho de uma época na qual o grande centro cultural ainda estava na Europa. Embora a cidade americana tivesse crescido e se desenvolvido, porém carecia de equipamentos culturais que dessem conta de criar em Nova York, um circuito artístico

\footnotetext{
${ }^{25}$ Depoimento do próprio Greenberg sobre a realidade artística de Nova York nos anos 1930 e sobre as dificuldades encontradas pelos artistas norteamericanos para desenvolverem seus estudos a partir de reproduções em preto e branco de obras de artistas europeus, sobretudo os modernistas da Escola de Paris. O crítico sente a necessidade de criar em sua cidade, estruturas e equipamentos culturais para formação e espaços de exposições para seus artistas. Este relato é sintomático de uma época de transformações profundas nas relações econômicas internacionais, na qual os Estados Unidos irão despontar como uma economia dirigente e terá em Nova York a representação e ostentação de seu poder. Relato em: O Final dos anos 30 em Nova York In: GREENBERG, Clement. Arte e Cultura- Ensaios Críticos. SP, Ed ática, 1996. P. 236
} 
importante e de referência internacional. Ao identificar esta demanda, Greenberg se destaca como o crítico de arte e o agente cultural que procurou articular e valorizar a produção artística novaiorquina, a fim de criar não somente em nova York, como também em outras cidades norteamericanas, uma rede de arte que não mais estivesse dependente e atrelada à programação cultural e editorial de Paris.

E era como se a resposta ou solução tivesse de esperar por uma assimilação mais completa de Paris. Não que se esperasse que Paris fornecesse a resposta completa, mas se acreditava que Nova York precisava se equiparar a Paris para poder colaborar no fornecimento desta resposta. ( Ibid, p. 237)

O crítico não só identifica a deficiência na cidade, como também se empenha em criar em Nova York um circuito de exposições locais, e uma troca intelectual entre os artistas norteamericanos a fim de fortalecerem suas criações artísticas. Nesta empreitada, o crítico e seu grupo assumem a arte abstrata, que será cunhada posteriormente como expressionismo abstrato, como uma estética autenticamente norteamericana. Greenberg desenvolve sua ação artística no sentido de atribuir aos artistas norteamericanos a independência cultural e um espaço de destaque na História da arte, pois o próprio crítico encarregou-se de articular conceitos para esta estética que de certa forma os ligavam aos movimentos artísticos modernistas europeus, incluindo-se como um movimento auge, não só da continuidade da História da arte, como também uma expressão importante da própria ruptura com a figuração e com a representação.

É neste contexto de crescimento e modernização das cidades norteamericanas que se situa a chegada do grande contingente de imigrantes especializados que se exilam da Europa por questões políticas ou pela perseguição nazi-fascista, e que encontrarão em Nova York, não só uma residência segura, mas também uma configuração de uma vontade política que possibilitou o espaço favorável para retomarem suas atividades de outrora e desenvolve-las ainda com mais vigor. Grandes mestres das academias européias, como por exemplo, alguns dos teóricos da Bauhaus, seguiram com suas pesquisas em solo americano, tais como Mondrian e Mies van der Rohe. Desta mesma maneira, muitos teóricos da escola alemã da Psicologia da Forma também se dirigiram para a América do norte, fugindo da repressão política nazista. A tríade da escola alemã da Gestalt, Wolfgang Köhler, Max Wertheimer e Kurt Koffka migraram para os Estados Unidos e passaram a ministrar cursos sobre as questões da percepção, dando continuidade às suas pesquisas e ampliando o debate de suas idéias. 
Em mesma circunstância histórica, Mário Pedrosa foge da repressão do governo brasileiro sob a ditadura de Getúlio Vargas e reside nos EUA de 1938 à 1945, onde tem a oportunidade de retomar seus estudos sobre as teses da gestalt com os teóricos alemães da psicologia da forma, como também tem acesso a diversos materiais sobre o assunto.

Pedrosa não somente conviveu com os teóricos, como também é possível que tenha acompanhado de perto as pesquisas estéticas de Piet Mondrian que também se deslocara para solo americano. Em seu caderno de anotações ${ }^{26}$ o crítico faz várias referências ao artista do De Stijl e problematiza suas afirmações que também se baseiam em teses da gestalt. Ao analisarse a fundamentação teórica sobre a arte abstrata, sobressai-se evidentemente a filiação do crítico às questões da percepção.

\subsection{A ARTE ABSTRATA- PANORAMA DAS IDÉIAS}

Mário Pedrosa concebe a arte abstrata como um projeto pensado e concebido a partir da evolução da arte moderna. Tal estética não é fruto de um impulso criador descompensado, mas é antes uma arte racionalmente sistematizada que acompanhou os pressupostos da ciência moderna, e que consolidou e cristalizou uma nova forma de ver e sentir o mundo e seus conteúdos.

Ao referir-se à análise de Wölfflin sobre a arte abstrata, aponta que este apresenta a visão de uma arte resultante da pura imaginação plástica que segue o espírito de uma cultura de época. Não somente este, mas vários estetas e historiadores da arte não conseguiram ultrapassar as barreiras da pura visualidade e adentrar na proposta abstrata enquanto um novo conceito de espaço bidimensional para a dinâmica das cores puras. Como um produto

\footnotetext{
${ }^{26}$ Tais interesses e retomada dos estudos gestálticos podem ser observados em um caderno de anotações pertencente à Pedrosa que corresponde ao período em que esteve nos EUA. Estas anotações remetem-se a reflexões e citações de conferências que assistiu sobre o assunto e uma série de textos fichados que tratam da questão da psicologia da forma. Segundo depoimentos proferidos pela Prof ${ }^{a}$ Anita Marcondes Cabral, ela assinala que neste período nos EUA houve uma série de conferências sobre o tema da Gestalt, que estava em pleno desenvolvimento e que Wertheimer foi referência de ponta neste momento. Tais depoimentos são citados pela Prof ${ }^{\mathrm{a}}$ Lisbeth Rebollo Gonçalves em seu livro Aldo Bonadei- $O$ percurso de um pintor, onde evidencia o desenvolvimento destes estudos também entre os artistas brasileiros. Bonadei e muitos outros artistas da época se aproximaram às teorias da gestalt a partir de conferências ministradas pela própria Prof ${ }^{a}$ Anita Marcondes na Biblioteca Municipal de São Paulo, quando a pesquisadora regressou ao Brasil. De igual modo, quando Pedrosa regressa ao Brasil, seus esforços foram concentrados na tese de 1949 "Da Natureza Afetiva da Forma na Obra de Arte" onde articula a relação das teses gestálticas com a arte. Algumas cópias das páginas do caderno, com destaques para algumas informações encontram-se nos anexos, ao fim deste trabalho.
} 
histórico, a arte responde aos anseios das conjecturas de sua época. Neste sentido, o campo artístico deve igualmente corresponder à "todas as novas descobertas do mundo visível,"27 (PEDROSA,1996, p.254) que infundiram a arte um novo rumo para suas premissas, uma vez que não se fazia mais necessária a representação do mundo como reprodução do real.

A arte fora ainda influenciada, em sua base epistemológica, pelas teses do universo da psicologia que invadiram o campo artístico e projetaram neste uma nova relação com a realidade e entre os próprios elementos constitutivos da arte "na medida em que a cor se tornou um meio de expressão para o psíquico, para a alma." (PEDROSA, 1996)

O desenvolvimento da área da psicologia influenciou a produção cultural do século $\mathrm{XX}$ em todos os seus âmbitos. $\mathrm{O}$ conceito de inconsciente minou a idéia do racionalismo puro e libertou a cultura dos compromissos da razão positivista e pode abrir-se aos enlevos da criação e da imaginação. No campo artístico, não fora diferente e a arte de então, dedicou-se à questões afins, em detrimento daquela vinculada à reprodução mimética. Liberta deste compromisso, a arte ganha autonomia e pode envolver-se com as propostas levantadas pela estética moderna.

A arte moderna, no entanto, nasce de uma inquietação sobre as problemáticas da luz e da cor e ao desenvolvê-las em suas múltiplas abordagens, chegou-se à dissecação total da pintura em seus elementos constituintes, a saber: ponto, linha, superfície, enquanto composição estrutural e a cor pura, enquanto componente "espiritual" que agrega à composição a sua própria lógica pois "as cores se regem por uma dinâmica que lhes é peculiar" (Ibid., p. 255) independente da vontade e do projeto do artista. A este cabe a potência criativa e intelectiva de articular e compor a obra, segundo as propriedades intrínsecas desta dinâmica das cores. A partir destas idéias, evidencia-se a influência da psicologia da forma sobre a fundamentação teórica da arte abstrata na concepção de Mário Pedrosa. O crítico não entende o projeto abstrato como pura imaginação plástica como o fizera Wölfflin, mas o compreende como uma construção que responde às características

\footnotetext{
${ }^{27}$ PEDROSA, Mário. Fundamentos da Arte Abstrata. In: Forma e Percepção Estética: Textos escolhidos II (org. Otília Arantes). São Paulo, EDUSP, 1996. p. 254. Neste ensaio de 1953, Pedrosa argumenta claramente sobre a sua compreensão da arte abstrata. Seus conceitos colocam em evidência o papel fundamental das teses da gestalt na constituição deste novo espaço pictórico. Assinala que os movimentos modernos cubistas a partir de Cézanne, perceberam a energia dinâmica da cor e das linhas de força da obra, mas que foram se perdendo em convulsões pictóricas por falta de um padrão que lhes impelisse ordem. A partir destas pesquisas, a psicologia se interessa pelas formas de apreensões visuais e descobre as leis inerentes aos objetos e cores na relação entre eles. Com estes parâmetros teóricos delineados, a arte abstrata pode encaminhar-se para uma produção equilibrada e cientificamente pensada. Nesse âmbito, encontram-se as produções de Kandinsky e Mondrian, entendidos por Pedrosa, como o expoente máximo das realizações abstratas de cunho construtivo.
} 
inerentes das próprias formas e cores e que segue a "ordem cromática necessária" nas relações de força do quadro.

A própria evolução da arte moderna se deu, porque os artistas perceberam que "as cores viviam num mundo próprio", que obedeciam outro sistema de leis do que aqueles estipulados pelos cânones acadêmicos. As técnicas renascentistas do claro-escuro, sfumatto e composição em degradês compunham uma área de transição entre as cores, que anulavam as relações cromáticas entre elas. $\mathrm{Na}$ arte abstrata, no entanto, a cor assume papel fundamental na composição e suas relações reordenam toda a modelação de profundidade e de espaço. Neste sentido, Pedrosa afirma que o espaço nesta estética passa a ser "conceitual em lugar de perceptivo". Diante destas novas relações compositivas na dinâmica do quadro, a dissolução do objeto é somente uma consequência, uma vez que a modulação do objeto diretamente pelas cores, reduz, em última instância, o objeto às suas linhas elementares. Foi este o exercício alcançado por Mondrian em suas composições de estudos sobre as árvores, que em suas investigações, chega à simplificação de tão somente linhas e cores.

Em todas as revoluções científicas, primeiro observa-se a prática, a realidade e depois com o intuito de organizá-la e fundamenta-la, soma-se a teoria. A revolução epistemológica do campo artístico seguiu esta mesma lógica. Primeiro os artistas apresentaram e desenvolveram suas inquietações plásticas acerca do uso das cores puras que de certa forma alteraram as relações de equilíbrio dinâmico do espaço pictórico. Em decorrência destas relações visuais, surge um ramo da psicologia que se interessará pela percepção visual e dos mecanismos de como nossa visão é afetada pelos objetos. Tal área será denominada psicologia da forma e será uma abordagem cientificista que acrescentará à arte a sistematização das relações pictóricas que faltavam à produção dos artistas. Esta ciência, também conhecida como teoria da gestalt (forma em alemão), será a fundamentação teórica que explicita de maneira racional e consciente as propriedades existentes nas relações entre os objetos. Esta área da ciência organizou o conhecimento que os artistas abstratos puderam exprimir em forma de arte segundo tais leis:

Os planos e as linhas, as zonas de cor, os perfis ou os pedaços de figura ou de objetos ordenados na tela se aproximam ou se afastam sob os fatores óticos perceptivos da distância ou da vizinhança, da simetria, do contraste ou da semelhança, da direção ou do movimento, num jogo permanente de combinações formais, independentemente de qualquer subordinação ao objeto ou ao assunto-tema do quadro. (Ibid,p.258) 
A revolução do espaço pictórico alcança consciência com Kandinsky e com Mondrian. O artista russo racionaliza a interação entre as cores; o holandês racionaliza o espaço pictórico e restabelece o equilíbrio perdido pela dissolução do objeto. Ambos, fundamentados pela teoria da forma, alcançam organizar as idéias e propostas levantadas como problemática pelos impressionistas, pós-impressionistas, fauvistas e expressionistas, que diagnosticaram e problematizaram as questões das tensões do espaço pictórico, mas não souberam como resolve-las. Considerando as investigações e conquistas plásticas de Kandinsky e Mondrian, que Pedrosa os elege como figuras icônicas no processo de desenvolvimento e maturação da arte abstrata, pois ambos estavam munidos pelas mesmas teorias da forma e vislumbravam com clareza as leis que organizam as formas e cores no espaço bidimensional. Estes artistas então, foram os mais capacitados para apresentar uma resolução aos problemas levantados pelos primeiros modernistas. Não porque fossem melhores, mas porque dispunham de ferramentas científicas que racionalizara os esquemas compositivos e poderia imprimir ordem e equilíbrio às propostas convulsionadas das primeiras investigações modernas.

Não por pouco, que os artistas abstratos se interessarão pelo estudo das teses da gestalt, como uma maneira de melhor compreender as relações pictóricas e dinâmicas do quadro, a fim de melhor combiná-las em suas composições, e o próprio interesse de Pedrosa advém da necessidade de compreender estas premissas artísticas da estética abstrata, para conhecê-las e ter condições de avaliá-las e elucida-las ao público em suas formulações críticas.

\subsection{O ENVOLVIMENTO DE PEDROSA COM A ARTE ABSTRATA}

Pedrosa foi pioneiro na atenção dedicada à arte abstrata e foi seu grande patrocinador no cenário da arte brasileira, além de ser o seu principal teórico. Nesta empreitada, no entanto, enfrentou a resistência equivocada da crítica nacional que mal compreendia as premissas desta estética que propunha a transposição da figuração em composições de conteúdos abstratizantes. Ciente da força interior desta nova arte e sua relação com uma nova sensibilidade, Pedrosa não só mergulha no estudo de suas teorias fundamentais em busca de sua compreensão, como também estimula esta produção no cenário artístico brasileiro. $\mathrm{O}$ projeto de modernização da cultura, não se restringia às instituições de arte. A própria linguagem artística deveria ser atualizada, para que então o Brasil alcançasse o 
reconhecimento da crítica mundial com uma linguagem inovadora e atual. Neste contexto, o crítico assumira-se como porta-voz deste novo movimento a fim de incorporá-lo ao seu projeto político:

Ao contrário dos muitos que então (no início dos anos 50) se interessavam por uma manipulação grosseiramente ideológica da arte, tomando-a apenas como um fundo ilustrativo na sequência de uma luta política, Pedrosa conhecia por dentro a dinâmica do processo cultural e dessa posição projetava seus lances. (...) ele o fez escolhendo conscientemente uma arte moderna de caráter construtivo nacional, racional, seguindo uma estratégia cultural que tinha raízes na própria realidade nacional. (...) Tratava-se, para Pedrosa, de criar uma arte adequada a um país novo 'com carteira de identidade' baseada numa vontade clara e racional de construção (...) ${ }^{28}$ (BRITO, 1975)

Esta premissa foi evidenciada por Pedrosa em seu entusiasmo e interesse no envolvimento dos artistas e atualização da linguagem artística brasileira pela arte abstrata. A força estética da nova arte seduziu o crítico, conquistando-lhe a adesão imediata, mas que provocou a reação desconfiada da própria crítica nacional:

\begin{abstract}
Mário Pedrosa pôs em pé de guerra a platéia (do auditório do Ministério da Educação num debate sobre "arte abstrata ou arte com temática social”) ao defender (...) a causa da abstração. (...) Inutilmente procurou mostrar aos presentes que a nova arte estava elaborando símbolos de uma linguagem plástica inédita, destinada a nos arrancar da atonia perceptiva quotidiana, na esperança de encurtar a distância que nos separa dos horizontes longínquos da utopia. (ARANTES, 1991,p. XIV)
\end{abstract}

A abstração se enquadrava dentro do social projeto moderno de valer-se da arte para promover a educação do grande público, como a grande aliada dos agentes sociais de transformação, para "reeducar a sensibilidade" e a abstração como uma linguagem universal poderia, com sua força simbólica, falar às mentes e às emoções. A força educativa da arte abstrata estava atrelada à expressão simbólica de seus signos. Não era uma arte ligada à academia e nem à tradição, ou seja, sua fruição dependia mais da experiência estética de cada espectador, do que o conhecimento prévio do lastro cultural da história da arte. Era uma arte independente, onde a forma e a cor tinham autonomia de significação, onde o diálogo era com as propriedades intrínsecas das formas e das cores inerentes à obra de arte, e não havia reminiscências da tradição acadêmica. Também não era uma arte autorreferente, ensimesmada, que se esgota em sua própria linguagem. A potência de sua ação estava no poder simbólico que abarcava, e na universalidade de sua apreensão, uma vez que todo espectador é capaz de estabelecer com a abstração, alguma relação estética devido às leis

\footnotetext{
${ }^{28}$ BRITO, Ronaldo. As lições avançadas do mestre Pedrosa. Opinião número 152. Rio de Janeiro,1975.
} 
internas do espaço pictórico, que em certa medida correspondiam à outras maneiras de interagir e perceber o mundo em constante transformação, onde as representações icônicas não faziam mais sentido:

\begin{abstract}
Marchamos para uma civilização de signos inéditos ou rejuvenescidos, ainda mal absorvidos, de imagens símbolos. Já a cibernética nos propõe uma civilização da pura comunicação, e não mais da força, nem da eletricidade, nem do vapor. Uma civilização de comunicação sem contato direto. A arte abstrata aparece também para educar o povo, prepará-lo para entender-se, para comunicar-se sem ser pela palavra ${ }^{29}$ (PEDROSA, 1996, p. 262)
\end{abstract}

Pedrosa acreditava que a nova linguagem inaugurada pela arte abstrata, colaboraria para a educação estética e crítica do público, no desenvolvimento da apreensão de uma produção artística diversa daquela figurativa, a fim de constituir o alargamento do cabedal crítico de cada espectador. Como um atento "cidadão do mundo" e um olhar perspicaz e cosmopolita, Pedrosa via na linguagem abstrata a realização dos intentos da arte moderna, em projeto, desde os impressionistas. Esta linguagem evidenciava um desprendimento da significação figural para uma compreensão sinestésica e objetiva dos elementos estruturais da "civilização das máquinas", que prezava pelo elementar e funcional. Deste modo, atualizar a linguagem pictórica brasileira era uma necessidade estética a fim de que a comunidade de artistas e a produção cultural brasileira acompanhassem e se preparassem para as novas formas de percepção de um mundo em franca transformação. Atualizar a produção artística e crítica brasileira com a realização das premissas da arte moderna era uma demanda do momento, para uma produção que ainda se representava pela figuração alusiva.

A arte abstrata, para além de mais um movimento artístico era uma proposta promissora de reeducação do olhar, em um mundo onde o cinema e a fotografia imprimiam novos olhares sobre os usos e representações das imagens. A arte assim perdera sua função documental e agora estava liberta de seus preceitos acadêmicos para a constituição de uma representação que de fato simbolizasse os valores de seu contexto. Estava então aberto o caminho para uma nova forma de diálogo com o espaço pictórico, que abria um elo de comunicação entre os componentes estruturais da pintura com a sensibilidade e emoção do espectador. Daquela logicidade renascentista que organizava o espaço pictórico a partir da perspectiva e da constituição de formas nuançadas pelas cores, vê-se o campo artístico em

\footnotetext{
${ }^{29}$ PEDROSA, Mário. Fundamentos da Arte Abstrata. In: Forma e Percepção Estética: Textos escolhidos II. ARANTES,Otília (org.). São Paulo: EDUSP, 1996. p.262
} 
plena autonomia para poder operar a partir do desenvolvimento de investigações engendradas pela imaginação criativa dos artistas.

Pedrosa estava convicto do sucesso da estética abstrata, de uma arte que estava a par das demandas simbólicas de seu tempo, que pensou ser este não somente um movimento, mas uma nova possibilidade de relação com o não verbal em uma sociedade que se encaminhava para a soberania da imagem.

\begin{abstract}
Assim, um dia o povo e os artistas restabelecerão, graças as realizações da arte abstrata, o contato perdido. Na decadência da civilização verbal, cuja curva descendente começa a delinear-se diante de nossos olhos e que arrasta consigo as conceituações mais sólidas e sagradas, a nova arte tenta restaurar o sentido das coisas eternas, dando vida a novos mitos que, só eles, poderão trazer aos homens uma nova razão de ser e de esperar. (PEDROSA, 1996, p.262)
\end{abstract}

Dentre as várias expectativas que Pedrosa projetava na estética abstrata, destacam-se algumas que estavam diretamente atreladas ao seu projeto político de sociedade. Poderíamos assinalar, primeiramente, a "essencialidade de uma educação estética para a sociedade", uma vez que tinha convicção na força sensibilizadora desta arte. Para tanto as propostas estéticas da arte abstrata, ou da chamada nova arte, eram-lhe instrumentos revigorados em suas premissas de aguçar as capacidades sensíveis e perceptivas do grande público.

Pedrosa também assinalava a importância da internacionalização da arte no mundo moderno. Para ser um país moderno, o Brasil deveria mostrar sua arte ao mundo e para desfazer-se de seu estigma de uma cultura exótica pitoresca deveria atualizar-se com o de que mais moderno se realizava no mundo de então, ou seja, a arte abstrata. A internacionalização da arte não era vista por Pedrosa como submissão à um modelo, como mera cópia. O que o crítico aspirava, somava parte de um projeto mais amplo de instigar artistas à fim de desenvolverem pesquisas estéticas inovadoras e atribuir à arte brasileira uma riqueza de linguagens, para que esta pudesse desenvolver, com subsídios atualizados, sua originalidade e expressão próprias. Diante de toda a expectativa de progresso e modernização que o país assistia na década de 1950, o projeto de Pedrosa era estender essa modernização principalmente à cultura e às artes, e realmente evidenciar ao mundo o nosso lugar entre os países de ponta no globo.

Para além de uma questão nacionalista, o crítico aspirava realizar no Brasil, o mesmo processo de sensibilização que a abstração suprematista alcançara na Rússia revolucionária. Tendo em vista suas filiações políticas, compreende-se porque o projeto revolucionário socialista nunca lhe saíra da mente. Era-lhe um vislumbre a longo prazo, onde, em sua 
concepção, a arte assumia o papel central de reeducação da sensibilidade e do espírito, preparando estes cidadãos para fazer acontecer a revolução permanente que instauraria uma sociedade mais justa e igualitária.

\subsection{UM CONTRAPONTO DA ESTÉTICA ABSTRATA: O EXPRESSIONISMO ABSTRATO DE CLEMENT GREENBERG}

Ao abordar a estética abstrata e o envolvimento de Mário Pedrosa com tais questões, faz-se necessário assinalar, outras vertentes abstratas que foram contemporâneas às idéias do crítico brasileiro. Faz-se necessário este contraponto, a fim de evidenciar o caráter construtivo da abordagem de Pedrosa e sua vinculação com um aparato teórico pari passu com a sociedade da técnica e da ciência, e sobretudo, de uma preocupação constante com uma fundamentação da arte abstrata que não estivesse atrelada ao puro subjetivismo plástico. No entanto, paralelas à estas concepções, corriam outras formulações que se afirmavam a partir da expressão abstrata subjetiva. Era a formação de uma Escola, que não só afirmava uma estética organicamente sua, como também, atraia o próprio circuito das artes para solo norteamericano.

Clement Greenberg foi um crítico de arte de grande relevância no debate sobre a abstração na história da arte ocidental no século XX. Sua influência foi decisiva para a afirmação do expressionismo abstrato e para geração de artistas norte americanos da década de 1950. Não somente por participar ativamente deste movimento, mas, sobretudo, por realizar uma obra que efetivamente propõe um discurso situado da arte e de seus pressupostos estéticos. Foi um teórico portador de uma crítica incisiva, com argumentos, por vezes, com pontos de vista absolutos, o que lhe renderam críticas contundentes por parte da geração de críticos com os quais dialogava. Greenberg foi um crítico que se engajou nas posturas artísticas e críticas que assumiu, uma vez que "seu envolvimento com a produção moderna não derivava de obrigação profissional ou acadêmica e sim de uma real afinidade" ${ }^{30}$ (GREENBERG,1996 p.8), relação tão próxima com a arte moderna que as premissas do crítico se diluíam em um discurso categórico e confiante.

\footnotetext{
${ }^{30}$ A citação refere-se ao ensaio de Rodrigo Naves sobre Clement Greenberg. NAVES, Rodrigo. As duas vidas de Clement Greenberg In: GREENBERG, C. Arte e Cultura- Ensaios críticos. São Paulo: Ed. Ática, 1996. P.8.
} 
Em seu texto seminal sobre a Pintura Modernista, Clement Greenberg lança suas concepções teóricas sobre a arte moderna, ou antes, da própria essência do moderno. Traça um percurso de idéias que remonta ao cerne do pensamento da Idade Moderna que teve por base a autocrítica de toda sua estrutura racional e filosófica. O próprio iluminismo que se constituiu como um movimento esclarecido de conhecimento e organização do saber tem início em uma perspectiva de crítica à um modelo social, político e econômico em franco sinais de desgaste e decadência. Greenberg delineia uma estrutura de pensamento que tem por base a idéia de crítica e crise, pois só há crítica quando há crise e necessidade de uma solução dialética, ou seja, uma nova reformulação a partir dos velhos pressupostos.

O pensamento de Greenberg segue as mesmas inflexões iluministas e apresenta uma filiação quase doutrinária do método e da perspectiva filosófica de Kant, intelectual que lhe desperta peculiar interesse. Assim como o filósofo vale-se dos limites da razão para balizar e estabelecer uma análise crítica da própria razão, o crítico desenvolve um método semelhante. Vale-se das premissas da arte, ou de uma perspectiva metalingüística a fim de articular uma autocrítica da própria arte sobre si mesma, de seus pressupostos e práticas a fim de estabelecer uma nova concepção sobre produção artística.

A crítica sobre arte vem de si mesma, em um movimento endógeno, num exercício de autocrítica e autodefinição. A área de competência de cada arte tem a ver com a natureza de seus meios, onde cada arte encontraria sua "pureza" no fato de delimitar a circunscrição epistemológica de sua existência e assim garantir padrões de qualidade e independência. A partir desta perspectiva maiêutica da crítica kantiana, as artes só se redimiram do questionamento, quando demonstraram que o tipo de experiência que propiciavam era válido por si mesmo e não podia ser obtido por nenhum outro tipo de atividade, atribuindo-lhe assim legitimidade e estatutos epistemológicos.

O paradigma da arte naturalista dissimulara os seus meios, usando a arte para ocultar a arte, onde copiar o real implicava em dissimular os componentes da pintura, de modo que não se pusessem evidentes no plano pictórico, o que se realizava de fato era a subversão da visão ao "entrincheirá-la" no reconhecimento fidedigno do real. Em contrapartida, o modernismo usou a arte para chamar atenção para arte, evidenciando-lhe as ferramentas tanto materiais quanto pictóricas, bem como seus processos de constituição.

O que outrora era depreciado, sob o modernismo as mesmas evidências processuais da matéria artística passaram a ser vistas como fatores positivos, passando a ser publicamente reconhecidas. Para Greenberg a definição de arte moderna está naquela que evidencia os 
próprios processos do fazer, deixa indícios do "modus operandi" da arte e compartilha com o público os liames entre a concepção, criação e realização do fenômeno artístico.

Greenberg não chega a formular uma teoria propriamente original da arte moderna. Seus textos sempre curtos, diretos e abrangentes sintetizavam idéias que encontravam formulações em outros autores, geralmente em escritos de artistas. Um texto de Maurice Denis de 1890, intitulado Definição do Neotradicionalismo, evidencia premissas das quais Greenberg compartilha: "Lembrar que a pintura, antes de ser um cavalo de guerra, uma mulher nua ou qualquer anedota é essencialmente uma superfície plana coberta com cores numa determinada ordem." ${ }^{, 31}$ (Ibid,p. 10)

Para Greenberg, a modernidade artística está na evidência do processo e não no foco do que de fato se quer representar. Notadamente as idéias de Greenberg apresentam filiações teóricas em historiadores da arte como Wölflin e Wörringer, e associa-se a vertente de uma tradição formalista da arte, pois o crítico volta-se a questões formais em detrimento de questões de tema e conteúdo. O crítico privilegia a conquista da planaridade e assinala que a única e exclusiva qualidade da pintura é a bidimensionalidade, diz o crítico "Por ser a planaridade a única condição que a pintura não partilhava com nenhuma outra arte, a pintura modernista se voltou para a planaridade e para mais nada."32 (COTRIM; FERREIRA, 2001,p. 103). O modernismo rompe com a tridimensionalidade que diretamente estava associado ao conceito de ilusão. A partir de então a pintura modernista liberta-se da mimese e evidencia-se como pintura, como um ofício manual com características e concepções próprias.

$\mathrm{Na}$ busca de traçar o característico da arte modernista, Greenberg vai se aproximando das questões estéticas que quer enunciar, para então postular o patrocínio de seu movimento artístico. Ao conceituar os termos da arte e de seus axiomas, ao delimitar um domínio próprio da pintura e assumir a planaridade como característica fundacional da condição de pintura, ainda que forçosamente, o crítico assinala a relação que deseja estabelecer:

\begin{abstract}
A tridimensionalidade é o domínio da escultura, e para preservar a sua própria autonomia, a pintura teve, principalmente, que se despojar de tudo o que podia partilhar com a escultura, e foi nesse esforço, e não tanto -repito- para excluir o representativo ou literário, que ela se tornou abstrata. (Ibid,p.104)
\end{abstract}

A arte abstrata para Greenberg seria o ponto mais representativo da idéia que o crítico constrói sobre arte moderna. Quando articula que o modernismo se orienta em uma direção

\footnotetext{
${ }^{31}$ Citado In: NAVES, Rodrigo. As duas vidas de Clement Greenberg In: GREENBERG, C. Arte e CulturaEnsaios críticos. São Paulo: Ed. Ática, 1996.p.10

${ }^{32}$ GREENBERG, C. A Pintura Modernista (1960). In: FERREIRA, Glória; COTRIM, Cecília (org.). Clement Greenberg e o debate Crítico. Rio de Janeiro: Jorge Zahar, 2001. P.103
} 
anti-mimética, que quer se libertar da figuração matérica da escultura e da tridimensão, afirma que a pintura modernista se tornou mais consciente de si mesma. Ao buscar um distanciamento da tradição e se lançar à novos pressupostos estéticos, o crítico falará na postura empírica que expôs a arte a novos riscos e a busca de novas normas.

O modernismo, segundo esta concepção, teve por base não a fixação de normas disciplinadoras de uma estética, foi antes a descoberta de que é possível ampliar esses limites estéticos indefinidamente. Assume a liberdade de criação, porém assume também a consciência de que quanto mais amplos os limites da arte, mas coerência empírica deve ter a proposta artística. Cada artista, ou movimento, vai articular sua criação em um campo de regras claras e definidas a fim de manter o estatuto artístico. O exemplo enunciado por Greenberg é Mondrian que se encaminha para absoluta abstração a partir de uma estética definida e disciplinada.

O modernismo para Greenberg é uma arte que se quer "liberta" dos pressupostos clássicos, mas que mantém regularidades normativas. Não é uma arte livre de regras, antes é a liberdade de ampliar os estatutos normativos de acordo com as propostas que se quer experimentar. Daí o crítico enuncia que o modernismo não tem um programa específico, o que se observam são propostas e caminhos individuais que, sobretudo, convergem à um núcleo comum. Um núcleo de autocrítica e autoconsciência da pintura. Embora estas propostas individuais tenham fomentado diversas linhas artísticas, as estruturas da pintura ainda se mantinham em torno da planaridade e do pictórico. Neste sentido Greenberg afirma:

\footnotetext{
(...) a arte segue seu caminho sob o modernismo da mesma maneira que antes. Além disso, não e supérfluo insistir que o modernismo jamais pretendeu, e não pretende hoje, nada de semelhança a uma ruptura com o passado. Pode significar uma transição, uma separação da tradição, mas significa também o prolongamento de sua evolução. A arte modernista estabelece uma continuidade com o passado sem hiato ou ruptura, e seja qual for seu término, nunca deixará de ser inteligível em termos de continuidade da arte. (Ibid, p. 107)
}

Embora a arte moderna inaugure novos repertórios artísticos e vanguardas estéticas, as condições estruturais da arte mantêm-se as mesmas como uma continuidade da tradição, ainda que com outros pressupostos. A idéia de concepção, escolha deliberada, criação e realização da arte seguem as mesmas. O modernismo em si não é uma escola teórica é antes a conjugação de possibilidades teóricas e possibilidades empíricas, ainda que, desfazendo-se de alguns dos pressupostos que antes eram condição "sine qua nom” para a fruição estética. A grande novidade do modernismo é ter sido capaz de dispensá-los e, no entanto, continuar a proporcionar a experiência artística em seus aspectos essenciais. A arte moderna segue 
essencialmente a continuidade inteligível do gosto e da tradição, uma vez que sem o passado da arte, "a arte modernista careceria tanto de substância quanto de justificativa"

\subsection{UMA INTERSECÇÃO DAS IDÉIAS: OS CRÍTICOS E SUAS CRÍTICAS}

A crítica de Arte é um instrumento necessário para evidenciar as propostas artísticas de um movimento, e, sobretudo, para articular um discurso que legitime a produção tratada diante da tradição da História da Arte. Neste sentido, a crítica de arte arregimenta critérios norteadores a fim de traçar uma circunscrição epistemológica para sua esfera de ação. $\mathrm{Na}$ prática, cada crítico deve deixar claro a que veio, uma vez que as premissas de seu discurso reiteram o seu lugar de enunciação, onde a crítica nunca se apresenta de modo impessoal e imparcial, mas antes é reveladora da perspectiva idiossincrática do discurso, e permite entrever as posturas ideológicas e os conceitos culturais, nos quais este crítico esta inserido.

As formulações críticas tanto de Mário Pedrosa quanto de Clement Greenberg, não se esgotam em análises estéticas e reflexões sobre conceitos, mas apontam para os projetos e realizações críticas em que cada qual esteve atrelado. Ambos os críticos estiveram ligados à fomentação de movimentos artísticos e foram agentes fundamentais para a modernização e atualização dos equipamentos culturais e artísticos de seus respectivos países.

Contudo, grandes diferenças se anunciam entre ambos. As idéias enunciadas por Clement Greenberg evidenciam um grande distanciamento, daquelas defendidas por Mário Pedrosa. Enquanto o crítico brasileiro identifica na estética abstrata uma ruptura com as maneiras tradicionais de composição e elaboração da arte, o norteamericano a caracteriza como uma continuidade dos mesmos pressupostos estéticos que somente variam nos padrões que formam a composição.

Em nenhum momento, Greenberg assinala a importância da visualidade abstrata, pois a entende como a sinergia de pulsões criativas e não como padrões rigorosamente elaborados a partir de leis específicas. Enquanto a gestalt fora para Pedrosa um norte para apreensão e assimilação do conteúdo e da forma na estética abstrata, para Greenberg tais teorias não incidiriam significativamente sobre uma arte que traduz as tensões subjetivas do indivíduo e seu universo interno.

O movimento abstrato para Pedrosa é caracterizado por uma linha lógica construtiva que visa unir os conhecimentos técnicos e científicos com a fruição estética da obra de arte. Já 
para Greenberg, o movimento abstrato se divide em distintas escolas que seguem impulsos personalistas de seus artistas que não coadunam investigações comuns.

Nota-se a distancia abissal que separa as duas correntes teóricas. No entanto, faz-se necessário este paralelo de idéias a fim de evidenciar as distintas polêmicas e formulações teóricas em torno da estética abstrata, uma vez que centrar-se em somente uma abordagem, sem ao menos recorrer a uma citação da outra, é entrincheirar-se em um conceito e anular a profusão dos debates que a abstração suscitou e que conduziu a projetos tão distintos de realizações artísticas. 


\section{AS APROXIMAÇÕES DE MÁRIO PEDROSA ÀS TEORIAS DA PERCEPÇÃO}

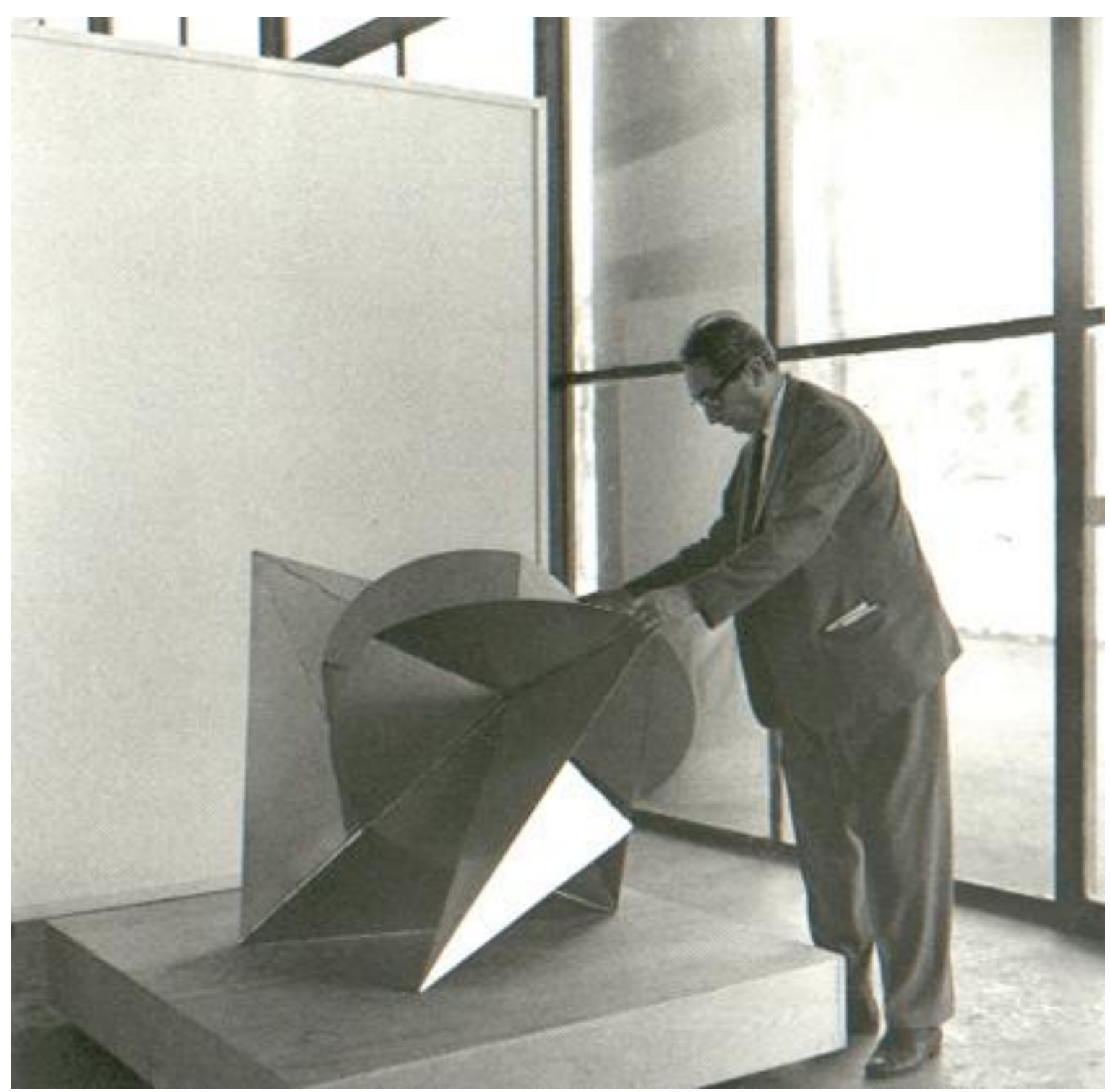

Figura 10: Mário Pedrosa e seu olhar nas esculturas da Bienal Fonte: http://www.eca.usp.br/pjbr/arquivos/especial_mural-139.htm 


\subsection{UMA APROXIMAÇÃO ÀS TEORIAS DA FORMA E PERCEPÇÃO NA TESE “DA NATUREZA AFETIVA DA FORMA NA OBRA DE ARTE": IDEIAS GERAIS}

Assinalado o contexto histórico no qual se inseriu a formação teórica de Mário Pedrosa com relação às teses gestálticas e seu entrosamento com a estética abstrata, propõe-se uma imersão nas ideias desenvolvidas pelo crítico em sua tese apresentada em 1949. Segue-se então, uma articulação teórica com o objetivo de identificar as motivações e os imbricamentos teóricos desenvolvidos por Mário Pedrosa com relação ao campo artístico. Intentou-se também, estabelecer correlações de alguns elementos indiciais teóricos comuns com outros autores, contemporâneos a ele ou não, quando se julgou pertinente e coerente a relação conceitual.

\subsection{DO INTERESSE PELO TEMA}

Em sua tese de 1949, "Da Natureza Afetiva da Forma na Obra de Arte" Mário Pedrosa desenvolveu um estudo pormenorizado sobre a percepção e o campo artístico, a partir das teorias gestaltistas. O crítico busca um aporte nas teorias de estudos da psicologia experimental, pois quer compreender como o homem apreende o conhecimento pelos sentidos, questão apontada por Pedrosa como "problema número um do conhecimento humano" 33 . Assim sendo, a percepção é a principal via de investigação, uma vez que é "a célula" da inteligência humana, a "base humilde de todas as conquistas e maravilhas", ou seja, é o principal meio de contato entre o ser humano e seu meio.

Ao dedicar seu estudo às preocupações estéticas e artísticas, o principal objeto será, sobretudo, o da percepção visual, uma vez que a visão é o sentido que diretamente se relaciona com as artes plásticas. A partir deste pressuposto, Pedrosa desenvolve sua tese, embasando-se nas teorias de vários estudiosos e nas demonstrações alcançadas por aqueles,

\footnotetext{
${ }^{33}$ PEDROSA, Mário. Da Natureza Afetiva da Forma na Obra de Arte. In: Forma e Percepção Estética: Textos escolhidos II- Otília Arantes (org.)- São Paulo: EDUSP, 1996. p.107. O crítico inicia seu estudo ressaltando a importância que atribui ao tema da percepção como forma de interação primeira com o objeto artístico ou com qualquer outra forma de conhecimento. A grande preocupação de Pedrosa é sobre como o espectador se relaciona com a obra de arte e como lhe atribui um sentido. Para tanto, desenvolverá esta tese no sentido de descrever e compreender esta relação e a partir daí poder traçar suas críticas com segurança, pois compreenderá melhor tanto a dinâmica interna à obra de arte, sobre o qual escreve, como também o ser-humano, espectador, para quem se destina suas análises estéticas.
} 
adotando inclusive, as mesmas designações conceituais dos autores aos quais se refere ${ }^{34}$. Nota-se nesta tese, o grande interesse do crítico pela apreensão do mecanismo da percepção, pois entende que somente poderia compreender a arte que o homem produz, depois de compreender o homem que a produz. $\mathrm{O}$ autor insere-se neste campo de estudo interdisciplinar com o objetivo de compreender a fisiologia da percepção humana para associá-la ao fenômeno artístico. Esta abordagem visava buscar uma via de compreensão da sistemática da estética abstrata, que perfez outro caminho para além daquele da estética clássica e demandou o conhecimento de outros domínios para sua interpretação. Como crítico de arte, Pedrosa sentia a necessidade de ampliar seu espectro de compreensão sobre a percepção humana a fim de identificar e poder assim analisar o dinamismo interno da obra de arte.

Pedrosa assinala em seu texto que "o estudo concreto dos elementos que compõem a estrutura de uma obra de arte, aproxima-se bastante das verificações experimentais da Gestalt"(PEDROSA, 1996, p. 138), deixando em evidência a razão de seu interesse por esta teoria e a explicação de sua inserção pelos estudos e constatações da psicologia experimental. O que Pedrosa quer de fato conhecer é como percebemos as estruturas que compõem a obra de arte, pois tal dissecação permite um aprofundamento da compreensão do fenômeno artístico e conhecer-lhe estruturalmente facilita a constituição de uma análise crítica e o levantamento de juízos e valores. Não podemos perder de vista, que Pedrosa é um crítico de arte, e como tal sua preocupação não é somente de um atento espectador, mas de um esteta especializado que busca na arte não só uma visão estilística, como também uma relação com a cognição humana. Desta forma, a teoria da gestalt é-lhe uma ferramenta aprimorada, um auxílio na constituição do juízo estético, uma vez que o ele procura fundamentação em estudos científicos, a fim de evitar uma crítica baseada na impressão subjetiva.

Sobre a utilidade destas teorias, Pedrosa explica em nota de rodapé: "Dão assim uma base científica e objetiva para o estudo da percepção estética e a análise psicológica dos problemas da forma em arte" ${ }^{35}$ (Ibid, p. 116). A aproximação de Pedrosa à teoria gestaltista

\footnotetext{
${ }^{34}$ Pedrosa articula sua tese a partir de diversas pesquisas e leituras que realizou sobre teóricos e pesquisadores sobre o tema da psicologia da forma. Ao longo de seu texto são citados diversos autores e seus referidos estudos, que indicam uma pesquisa intensa e um profundo interesse do crítico sobre o assunto. No entanto, embora seu texto fosse um trabalho de cunho acadêmico, nem sempre o crítico cita adequadamente suas fontes. Diversas vezes, aborda um assunto e chega a algumas conclusões, sem citar com clareza suas referências e filiações teóricas.

${ }^{35}$ Comentário de nota de rodapé. O crítico faz questão de evidenciar o caráter cientificista de sua tese a fim de incluir os estudos artísticos na categoria de estudos científicos, e como tais, legitimá-los com o rigor metodológico das pesquisas empíricas. Este objetivo deriva de uma crítica corrente ao campo artístico, que por centrar seu objeto de análise na criação e produção estética, é considerado pela comunidade científica como produto do universo subjetivo e das impressões imaginativas. Assim sendo, não dispõe de parâmetros objetivos para constituir-se como uma disciplina cunhada na racionalidade.
} 
relaciona-se, não só, ao interesse pelo estudo sistemático dos mecanismos de percepção e apreensão dos objetos, mas principalmente por ser uma tentativa de racionalizar a subjetividade. Por ter uma dimensão simbólica, a arte estaria intrinsecamente relacionada a uma "vertente humana imprevisível", ou seja, relacionada a um conteúdo irracional e plenamente atrelado às significações subjetivas que não são plausíveis de sistematização e análise. A inserção neste campo teórico tinha como objetivo, investigar o processo de como se dava a aquisição dos elementos que compõem tal universo subjetivo, para poder então, analisar-lhe as significações.

A via da gestalt foi justamente o ponto de apoio que Pedrosa buscava, a fim de atribuir ao objeto artístico uma análise científica e objetiva. No entanto, João Frayze-Pereira assinala que o interesse de Pedrosa pela psicologia da forma transcende à questão da pura qualidade científica:

\begin{abstract}
Mas, a partir daí, não é possível pensar que Pedrosa se interessaria pela Gestalt, tendo em vista apenas a busca de fundamentos científicos para a crítica da nova arte. Mais profundo, tal interesse era motivado pela expectativa de superação das oposições forma/conteúdo, inteligência/sensibilidade, imaginação/realidade sob as quais se oculta uma outra: a clássica antinomia subjetividade/objetividade. Para essa problemática epistemológica, a noção de Gestalt parecia oferecer uma solução, uma vez que seria possível explicar a experiência estética por intermédio das propriedades intrínsecas da forma. ${ }^{36}$ (FRAYZE-PEREIRA, 2007 p.131).
\end{abstract}

Nesta citação, situa-se a vinculação de Mário Pedrosa com a psicologia da forma e tem-se assinalado o seu interesse por estas questões que traziam uma teorização coerente a entraves conceituais relativos ao fenômeno artístico. Esta preocupação, em que o crítico imergiu, demandou um estudo de diversos autores e linhas teóricas. Este empenho pode ser observado nos rascunhos que antecederam a escrita da tese e na grande quantidade de autores citados e textos fichados, que formaram a base para a argumentação de Pedrosa neste seu estudo $^{37}$. Estas idéias não ficaram restritas ao desenvolvimento da tese para o concurso ${ }^{38}$ no

\footnotetext{
${ }^{36} \mathrm{O}$ grifo vale-nos com o intuito de destacar do argumento citado, que o interesse de Mário Pedrosa pelas teses da gestalt atrelava-se a diversas dimensões e objetivos.

${ }^{37}$ Mário Pedrosa cita uma grande quantidade de teóricos e referências bibliográficas em sua tese. Várias citações incluem autores e suas referidas publicações. No entanto, há diversas citações de idéias, ou mesmo de autores que não estão seguidas de suas publicações e de referências bibliográficas completas. Esta lacuna foi levantada pela arguição da banca de avaliação no concurso catedrático da Faculdade Nacional de Arquitetura como uma falha antiacademica, por valer-se da apropriação de argumentos de outros sem as referidas indicações da autoria.

${ }^{38} \mathrm{O}$ texto "Da Natureza Afetiva da Forma na Obra de Arte" foi redigido por Mário Pedrosa, a fím de concorrer à cátedra de História da Arte na Faculdade Nacional de Arquitetura. A tese foi defendida em doze de janeiro de 1951 as 15 horas na então Universidade do Brasil, hoje, a atual Universidade Federal do Rio de Janeiro. A banca examinadora foi constituída por Frei Sebastião Hasselman e os Professores Pedro Calmon, Lucas Meyerhoffer Magalhães, Jayme Coelho e Carlos Del Negro. (talvez a grafia dos nomes dos professores não esteja completa, porém tal indefinição se deve à ilegibilidade destes nomes no documento pesquisado). Informações encontradas
} 
qual se inscreveu, mas foram importantes porque acompanharam Pedrosa por várias décadas em seu percurso crítico e consolidaram um modo de análise do fenômeno artístico.

\subsection{OS PRESSUPOSTOS TEÓRICOS}

A escolha do título "Da Natureza Afetiva da Forma na Obra de Arte" para sua tese revela claramente algumas das propostas teóricas por ele defendidas. A escolha das palavras não é despropositada, e nos permite esboçar alguns apontamentos sobre as teorias abordadas no estudo. O título apresenta a idéia da "natureza da forma", o qual logo de início, revela sua vinculação com a psicologia da forma, ou a chamada Escola da Gestalt. Este ramo da psicologia se ocupa do fenômeno da percepção, ou seja, dedica-se à compreensão do processo de percepção a partir do contato dos órgãos sensitivos humanos com um objeto. No caso específico desta abordagem, a problemática recai sobre o objeto ou fenômeno artístico e empreende uma investigação a fim de compreender como a estrutura fisiológica cerebral humana percebe e assimila as atribuições desta produção diferenciada, que é a arte.

Estes estudos são também chamados de Gestálticos uma vez que a tradução da palavra "Gestalt" do alemão é geralmente traduzido como forma, muito embora, alguns teóricos apontem que a palavra abarque um sentido mais amplo relacionado à estrutura, figura, podendo ser definida como uma integração de partes em oposição à soma de partes. A própria definição da palavra designa a tese fundamental desta escola ${ }^{39}$. Esta escola se assenta e consolida seu esquema interpretativo, a partir de críticas contra as teses estabelecidas pela psicologia clássica, também chamada de associacionista, ou atomista, que apresentava esquemas insuficientes para explicar os processos perceptivos. Segundo a psicologia tradicional, a percepção da forma era compreendida como resultado da soma de sensações

em artigo de jornal datado de 12 de janeiro de 1951, sem a indicação do nome do Periódico, intitulado "Na Faculdade de Arquitetura- O crítico Mário Pedrosa defenderá tese hoje" pertencente à coleção Arquivo Mário Pedrosa da Biblioteca Nacional/RJ.

${ }^{39}$ FRACCAROLI, Caetano. A percepção da forma e sua relação com o fenômeno artístico: O problema visto através da Gestalt. Aula no 30-Plástica III, Setor de publicações, FAU-USP, 1952. O autor organiza esta coletânea para aulas ministradas na Faculdade de Arquitetura e Urbanismo da Universidade de São Paulo, na qual desenvolve a mesma problemática da percepção estética. Seu estudo apresenta, de modo sintético e didático, o tema da gestalt e suas implicações no campo da arte. O próprio autor assinala ser este um campo de interesse crescente no período da década de 1950, campo este também explorado por Mário Pedrosa com grande interesse. 
isoladas. Á partir do modelo da percepção visual, a teoria associacionista descreve que a luz incide na retina e se propaga da mesma forma ao cérebro, indo estimular pontos isolados do córtex cerebral. A forma seria então gerada em um momento posterior por um processo de associação dessas estimulações isoladas (FRACCAROLI, 1952). Para atribuir um sentido e significação à forma percebida, o cérebro recorreria às experiências armazenadas na memória para designar-lhe um significado, de acordo com as experiências já assimiladas anteriormente. De acordo com a psicologia tradicional, o cérebro recorre à experiência e à memória para realizar a associação do significado da forma percebida.

Este esquema interpretativo, no entanto, não se estendia a todas as situações visuais. Um exemplo desta insuficiência está relacionado ao fenômeno da ilusão de ótica, que opera segundo um padrão visual que não existe de fato, e, portanto, a construção do signo não encontraria correspondente na experiência e na memória. $\mathrm{O}$ que provocava o questionamento da psicologia clássica era o fato de a imagem que provoca a ilusão óptica estar sempre relacionada a um conjunto de elementos, nunca podendo ser percebida em um ponto isolado. Partindo desta inquietação, a escola da gestalt propõe a teoria de que a percepção se dá pela relação recíproca das várias partes dentro do todo. Dedicando-se ao método empírico, os gestaltistas vão desenvolver teses que visam explicar como funciona o esquema cerebral.

Em sua tese de 1949, Mário Pedrosa inicia seu argumento a partir destas considerações. Embora este panorama das ideias psicológicas não fique claro em seu estudo, o autor parte já de um embasamento consolidado da psicologia da forma e arrola seu argumento partindo da tese de que há uma estrutura intrínseca na forma em tudo o que vemos. Assim, diz o autor, que tais formas nos chegam pela visão por causa das estruturas elementares que lhe são inerentes e que são percebidas pela nossa fisiologia de apreensão visual. Desta maneira, Pedrosa quer trazer à arte, uma constatação da psicologia experimental, de que a estrutura elementar inerente à forma é um dado natural, lhe é intrínseco e não é um dado cultural, ou mesmo histórico. As características formais do objeto não estão fora dele, nas estruturas culturais das sociedades, mas são propriedades dos objetos. Para comprovar tal tese, Pedrosa se valerá de diversas citações de demonstrações experimentais, principalmente com animais e crianças, que evidenciaram os resultados que puderam encaminhar tal conclusão.

$\mathrm{O}$ aporte de pesquisas com animais e crianças foi necessário para observar experimentos que comprovassem a tese de estruturas elementares naturais das formas dos objetos. Tais procedimentos empíricos foram aplicados a estes dois grupos, pois constituem 
amostragens de tipos vivos que não passaram ainda pelo processo "civilizatório" 40 , entendido por Pedrosa e por estes teóricos, como condicionante a uma visão de mundo a partir de um ponto de vista cultural, situado em um tempo e um espaço. Uma vez que "as concepções que temos sobre as coisas influem na própria percepção que temos delas", os teóricos buscarão excluir os conhecimentos adquiridos pelo processo civilizador, e querem observar a situação fenomênica de uma "experiência primeira", de um primeiro contato com determinados objetos, sem a intermediação de idéias pré-concebidas. E querem, então, tomar nota das reações expressas diante das formas desconhecidas e assinalar constatações teóricas a partir das reações observadas nestes experimentos.

A tese do estudo não se detém, entretanto, na análise de fatos empíricos. Mário avança e articula um enredo que enlaça a relação da obra de arte com uma dimensão afetiva. Mas o que o autor quer dizer com esta dimensão afetiva? O que o afeto, ou a afeição tem a ver com a percepção da obra de arte? Por que associa a "forma" na obra de arte com uma "natureza afetiva"?

A "natureza afetiva" de que fala o autor, não está relacionada diretamente a afetos, mas liga-se à maneira como a obra de arte nos afeta. A tese que Pedrosa defende é a de que a obra de arte tem qualidades intrínsecas, estruturas próprias que se apresentam ao espectador com sua força mesma, independente de conceitos e abstrações teóricas. O grau de afetação estética será determinado pelo envolvimento do espectador com a obra de arte, por ela mesma, e pela capacidade deste de absorver o que a forma do objeto artístico é capaz de oferecer-lhe, por sua própria natureza e por suas leis inerentes.

Esta linha se opõe à estética inspirada na psicologia idealista associacionista, "para a qual por detrás de uma obra de arte, de uma forma plástica, há sempre uma associação para significação intelectual que nos dará a chave para compreender a 'beleza' ali contida”. As leis da psicologia da forma constataram que "os objetos têm por si mesmos um caráter próprio em virtude de sua própria estrutura e são independentes de toda a experiência anterior do sujeito que os percebe", tal afirmação contrapõe-se à participação da memória na relação estética do

\footnotetext{
${ }^{40}$ Termo usado pelo sociólogo alemão Norbert Elias, autor da obra $O$ Processo Civilizador publicada em 1939 sobre as dinâmicas culturais e esforços de grupos sociais, para imprimir à sua época determinados costumes e regras que condicionam a sociedade a determinados valores morais e comportamentais. A obra tornou-se importante na Sociologia, pois em seu método de análise articula história, teoria social e psicanálise ao relacionar o conceito de civilidade com determinações sociais que condicionam esquemas comportamentais e cristalizam respostas psíquicas. Embora esta obra esteja vinculada aos comportamentos sociais e tampouco se refira às designações estéticas, o que nos vale neste ponto é a ideia de um condicionamento cultural a determinadas formas de pensamento construídas a partir de pré-estabelecidas maneiras de ver, perceber e sentir. No caso específico das pesquisas gestálticas, os cientistas valeram-se das categorias psíquicas de crianças e animais, pois estes estariam mais próximos do estado de natureza, pouco vinculados aos condicionamentos sociais e culturais de suas épocas.
} 
indivíduo com o objeto de arte, e é contrária à idéia de que o sujeito observa na obra aquilo que lhe reverbera significação, ou que lhe ecoa uma situação semelhante de afetação emocional.

Pedrosa dedica grande parte de seu estudo à citação de demonstrações de vários cientistas para evidenciar como tal linha teórica pode falsear a significação que o espectador faz da obra de arte, pois à medida que o espectador projeta suas próprias experiências e julgamentos, priva-se da oportunidade de assimilar uma nova experiência que poderia ter sido proporcionada por aquela forma artística ainda desconhecida.

O contato com a nova forma é a via de possibilidade de alargamento das experiências sensoriais, e deve ser entendida como o mecanismo de uma nova experiência para a psique e não associada com o universo já conhecido e identificado da memória. Pedrosa afirma que "não percebemos em uma situação apenas o que nos interessa, o que pode satisfazer uma necessidade", a impressão global dá-se também em situações despropositadas ou mesmo naquelas que não se incluem nas atividades pragmáticas do homem. Assim a percepção vai além da consciência de uma escolha e "não segue um utilitarismo a serviço de uma adaptação biológica", mas responde aos estímulos sensoriais com mecanismos estruturais.

A grande preocupação de Pedrosa é compreender como se dá a relação "afetiva", como opera a fisiologia de afetação da obra de arte sobre o espectador e o processo pelo qual este lhe atribui um significado. Sua preocupação dirige-se em conhecer os mecanismos que ligam esta forma à percepção humana, e de como os sentidos humanos, sobretudo a visão, a apreendem e formulam um entendimento para ela. O problema da forma para Pedrosa está relacionado mais ao espectro da apreensão do que ao universo da criação, diz o crítico: "Quando se aborda o fenômeno artístico, a característica sensorial da pura percepção estética indica que o problema fundamental, não é o de saber como os objetos são concebidos, mas como nós os percebemos". ${ }^{41}$ (PEDROSA,1996, p.109) Portanto, a questão central para o autor, não é encontrar a natureza da forma na arte enquanto origem criativa, sua definição e características inerentes. A investigação do autor visa compreender não a origem da forma na obra de arte, ou de como ela é produzida como gênese artística, mas visa, sobretudo, traçar o mecanismo de como a organização percepcional humana apreende esta forma e incorpora esta nova experiência ao seu aparato cognitivo. O crítico se interessa por um esquema de leitura da forma da obra de arte e neste argumento que desenvolve não se ocupa com a dimensão criativa do artista, de como a forma é pensada e gestada por seu produtor ou criador. A

${ }^{41}$ PEDROSA, Mário. Da Natureza Afetiva da Forma na Obra de Arte. In: Forma e Percepção Estética: Textos escolhidos II- Otília Arantes (org.)- São Paulo: EDUSP, 1996. (Parafraseado) P.109 
preocupação do crítico, entretanto, reside na comunicação entre obra de arte e o espectador, e nesta relação, o foco de pesquisa de Pedrosa é identificar como opera a recepção da obra de arte pelo aparato perceptivo do espectador.

Pedrosa tangencia uma discussão que será arregimentada com maior força teórica ,posteriormente, nos anos 1970, quando se formula uma série de conceitos sobre a chamada Estética da Recepção, tendo um de seus expoentes teóricos no discurso de Hans Robert Jauss. $^{42}$

\subsection{A PSICOLOGIA DA FORMA VISTA POR MÁRIO PEDROSA: TEMAS INERENTES À OBRA DE ARTE}

\subsubsection{Reverberações Teóricas}

A problemática da tese de Mário Pedrosa reside em estudar como a forma da obra de arte afeta a percepção humana, e quais os processos envolvidos neste mecanismo. A tese quer evidenciar desta maneira, o momento de encontro da percepção humana com a forma do objeto de arte, e é este encontro relacional que será o foco das atenções de Pedrosa ao longo do estudo. Sua averiguação, porém, será desenvolvida de modo sistemático e gradativo, pois o

\footnotetext{
${ }^{42}$ Jauss é um dos teóricos da Estética da Recepção e desenvolve atribuições para a relação entre o espectador e a obra de arte. A preocupação deste teórico incide sobre a "experiência estética", ou seja, a relação espectadorobra de arte visando preencher uma lacuna nos estudos da disciplina Estética que se detinham nas questões metafísicas e filosóficas do campo artístico e pouca atenção dispensavam à relação fenomenológica do sujeito com o objeto de arte. Assim, Jauss questiona o senso comum que associa a produção artística como atributo do gozo estético idealista e a redimensiona como uma área do conhecimento solidamente fundamentada na tradição de uma fortuna crítica da filosofia que transformou a Estética em disciplina científica e autônoma. Sua importante obra Pour une esthétique de la réception, discute sobretudo, relações de significação com textos literários. Esta obra, no entanto, traz um capítulo que se detém às questões artísticas em Petite apologie de l'expérience esthétique, onde o autor enreda várias teses que atribuem novo estatuto à experiência estética no mundo moderno. Na medida em que a arte se distanciou da dimensão representativa das classes nobres e burguesas, diz o autor, ela pôde atrever-se às outras investigações e estabelecer uma nova relação com o prazer, não mais atrelado ao sentido do gozo estético do belo e da virtude, tal como previsto pela tradição da filosofia clássica que fundamentou os parâmetros da prática artística até meados do século XIX. Esta nova acepção de "prazer" está associada ao envolvimento lúdico do espectador com a obra de arte, a partir de uma "experiência", ou seja, um momento de encontro descrito em três dimensões: a da Poiesis, da Aesthesis e da Catharsis, que respectivamente remetem-se a um sentimento de sentir-se do mundo; uma nova forma de perceber o mundo e por último, o usufruto da obra de arte em uma relação não pragmática com a significação ou atividade real. Neste sentido, a nova relação de experiência com a arte dá-se na vivência com a proposta do objeto artístico, que uma vez desvinculado do compromisso com o belo e com o pragmatismo burguês, pode oferecer ao seu interlocutor, diversas outras dimensões perceptivas e lúdicas das realidades vividas.
} 
crítico, ao desenvolver o estudo, o divide em quatro partes independentes, que abordam as questões da gestalt aplicada à arte em diferentes nuances: As leis da estrutura, Figura e fundo, Forma e significação e Forma e expressão.

Mário Pedrosa inicia sua tese enunciando o problema da percepção e, imediatamente, insere-se nas teorias da psicologia da forma, oferecendo ao leitor uma sistematização das leis psicológicas que regem a estrutura da visão agregadas a reflexões sobre o campo das artes e suas implicações estéticas. Enunciadas as leis da estrutura, Pedrosa se atém ao estudo atento sobre a relação Figura-fundo e suas implicações perceptivas. Demonstra vários experimentos com figuras e comenta conclusões alcançadas. Tal conteúdo é tratado de maneira técnica e situa as leis da gestalt em uma dimensão um pouco distante da problemática artística.

Em um segundo momento, o crítico parte à relação Forma e Significação, explorando os processos cognitivos sobre a elaboração mental de significação, sobre o que afeta a percepção. Explora o fenômeno da "experiência primeira", como uma experiência estética desconhecida, que envolve uma nova interação entre o sujeito e o objeto artístico e opõe esta situação à teoria de que toda experiência perceptiva somente tem um significado para o indivíduo, se houver uma identificação com as experiências vividas e acumuladas na memória. Pedrosa desenvolverá longa discussão sobre esta díade "experiência primeira" e "memória", atribuindo à tese da originalidade da primeira aquisição experiencial, todo o aporte teórico das leis gestaltistas e de suas evidências empíricas. ${ }^{43}$

Interessado por esta linha de pesquisa, Pedrosa atribuirá à "experiência primeira" uma importância relevante na relação fenomênica com a arte, pois é neste primeiro contato que o aparato perceptivo do indivíduo estará processando e assimilando um novo conhecimento para tessitura de um repertório sensório mais abrangente. No entanto, este primeiro contato

\footnotetext{
${ }^{43}$ Para Mário Pedrosa a questão da experiência é uma abordagem fundamental na análise artística. Desde o início de sua tese, Pedrosa assinala a importância da experiência com a forma da obra de arte a fim de construir com ela, a sua significação, rejeitando, para tanto, o papel da memória e de experiências passadas. Esta problemática da experiência estética já fora desenvolvida por John Dewey em sua obra Arte como experiência de 1934. Embora pareça anacrônico assinalar a abordagem da mesma problemática, nota-se em Dewey uma concepção de experiência artística definida como uma atividade livre e prazerosa e apresenta uma perspectiva diversa daquela constituída pelas teses gestálticas que estabelecem a experiência como um momento em que o aparelho perceptivo humano realiza uma aquisição fisiológica dos dados que foi capaz de perceber e captar. Vê-se uma relação mais clara entre as idéias de Dewey e a estética da recepção de Jauss, do que com as idéias de Pedrosa, à época da tese. Ambos, tanto Dewey, quanto Jauss se debatem com as idéias de Kant e o tomam como ponto de discussão. Kant fala das "Belas Artes" como uma arte do prazer estético, mas cunhada no sentido do bem e da virtude. Jauss falará que o prazer estético deve estar no lúdico da experiência e do prazer estético que a agregação de uma nova forma de percepção proporciona. Parecem-nos interessante tais apontamentos, pois as teses de Dewey apontam orientações próximas às teses fenomenológicas que posteriormente foram desenvolvidas por Merleau-Ponty. No momento de sua tese, Pedrosa situa-se em uma abordagem que busca uma regularidade conceitual para melhor compreender o sistema de percepção humano a fim de associá-lo à assimilação dos novos parâmetros da arte abstrata. Diante de tal panorama, assinala-se a abordagem da mesma problemática, no entanto pensada a partir de esquemas conceituais diversos.
} 
não deve ser mediado por informações externas a ele, pois a forma em si, traz consigo estruturas intrínsecas que serão apreendidas pelos processos gestálticos da percepção. Sobre este momento, Pedrosa diz:

Estas impressões primeiras serão o alicerce da impressão estética, nas quais a arte se funda e perde sua força expressiva, sua pureza, quando essa percepção global sincrética se mescla com preocupações analíticas, ou exigências externas ao indivíduo, didáticas, científicas, intelectuais, morais, religiosas, práticas, etc... a arte deixa de ser fim para ser meio. ${ }^{44}$ (PEDROSA, 1996,p.108)

Mário Pedrosa investe neste conceito de "experiência primeira" como um encontro entre o indivíduo e a obra de arte, assinalado como um momento de descoberta. No entanto, esta "descoberta" deve ser "pura", ou seja, o indivíduo deve estar munido somente de sua capacidade perceptiva e não estar carregado e "contaminado" com bagagens teóricas e abstrações conceituais que atrapalhariam o mecanismo natural de percepção das características inerentes à forma do objeto artístico, pois "processos como os analíticos dissecam e retalham essa impressão, destruindo as qualidades sensíveis que nos deram o conhecimento primeiro do objeto". Nota-se neste argumento a influência das teses de Koffka sobre a questão dos valores pré-concebidos da obra de arte. Fraccaroli explicita as ideias do teórico alemão, onde se aborda a influência dos postulados culturais como um direcionamento condicionante à visão e apreensão da obra de arte, relação esta que deveria ser espontânea e desvinculada de formulações conceituais :

\begin{abstract}
A resposta de Koffka é em termos do que ele chama "conceito de classe". Em consequência de preocupações de ordem cultural, ou seja, de preconceitos intelectuais, morais e religiosos, o sujeito se desvia da percepção espontânea e puramente formal do objeto. Há uma cortina de bagagem cultural que lhe impede esse contato direto com os valores reais de uma obra de arte. ${ }^{45}$ (FRACCAROLI, 1952)
\end{abstract}

Sobre esta questão, Pedrosa recorre às ideias de outro teórico, H. Delacroix ${ }^{46}$ onde observa que "a arte restaura o valor dessa qualidade sensorial em que nossa consciência está imersa, e da qual a ciência aspira emancipar-se". A arte traz em seu bojo a possibilidade de uma experiência estética e uma espécie particular de conhecimento que a ciência cartesiana

\footnotetext{
${ }^{44}$ PEDROSA, Mário. Da Natureza Afetiva da Forma na Obra de Arte. In: Forma e Percepção Estética: Textos escolhidos II- Otília Arantes (org.)- São Paulo: EDUSP, 1996. (Parafraseado) P.108.

${ }^{45}$ Citado por FRACCAROLI, Caetano. A percepção da forma e sua relação com o fenômeno artístico: $O$ problema visto através da Gestalt. Aula no 30-Plástica III, Setor de publicações, FAU-USP, 1952.

${ }^{46}$ DELACROIX, H. Psychologie de l'Art, Paris, Alcan, 1927. Pedrosa cita diversos autores em seu trabalho que desenvolveram questões sobre a mesma problemática da psicologia da forma e da psicologia da arte. Com estas citações, evidencia-se o profundo interesse por esta questão e o esforço do crítico em informar-se sobre o assunto.
} 
deprecia por considerar potencialmente subjetiva e carente de métodos racionalizáveis. Em comparação à teoria do Einfühlung ${ }^{47}$, Pedrosa assinala que a experiência estética ali é manifesta no sentido do criador, do artista, pelo fato de o espectador colocar-se no lugar do artista, e relacionar-se com esta arte partindo de emoções e movimentos internos. Segundo esta vertente interpretativa, a emoção estética se enquadra como uma experiência puramente subjetiva. Para a teoria gestaltiana, no entanto, não há tamanho subjetivismo, uma vez que a experiência estética se vincula a um esquema motor cerebral designado por processos fisiológicos, se faz possível o desenvolvimento de análises cognitivas e estéticas dentro de parâmetros previsíveis.

É justamente esta discussão 'objetividade $\mathrm{X}$ subjetividade' que Pedrosa levanta e encontra na gestalt a vertente "científica," munida de uma sistemática metodológica e postulações verificáveis que atribuiriam à arte a credencial de ciência do conhecimento, ainda que, como uma área com especificações peculiares. Após as investigações pela gestalt e notando sua insuficiência teórica para dar conta das novas acepções estéticas do neoconcretismo, Pedrosa também buscará aporte na fenomenologia, pois encontrará nesta um alargamento conceitual para poder avançar na compreensão da subjetividade que, percebe ali, ser inerente à experiência estética. Antes, porém, de enamorar-se das questões fenomenológicas, o crítico encontrará apoio metodológico nos conceitos da psicologia da forma, os quais por um período demonstraram ser um terreno seguro e suficiente para explorar e compreender os parâmetros da percepção humana enquadrando-a nas demandas da estética abstrata.

Em sua tese, Pedrosa assinala que estetas e historiadores que não conhecem essa teoria da percepção gestáltica, quando vão tratar de arte, não conseguem sair de um círculo vicioso, pois ou se delimitam ao campo da pura técnica plástica ou recaem no universo do subjetivismo abstrato. Interpretam a arte como técnica ou como impulso subjetivo e ignoram as questões científicas que englobam o campo artístico, tais como os estudos da geometria, linhas e cores, como também as relações visuais e perceptivas que se agregam como leis naturais ao pressuposto do fenômeno artístico, tanto em sua criação, como em sua apreensão.

Um exemplo expressivo do impacto gerado pelos estudos gestálticos sobre as formas de conhecimento da percepção artística, foram os estudos desenvolvidos na Escola da Bauhaus nos períodos em que se desenvolveu em Weimar e em Dessau. Esta escola legou às

\footnotetext{
${ }^{47}$ Einfühlung é a palavra alemã que significa entendimento ou empatia e foi usada por fenomenólogos como Edmund Husserl para explicar uma forma de conhecimento que procura entrar na experiência de outro ser humano e conhecer e sentir o mundo da mesma forma que esse ser humano.
} 
artes e ofícios do século XX uma experiência revolucionária, em um momento curto, mas muito prolífero no campo das artes e das ciências, pois incorporou criatividade e experimentação exuberantes na pauta de suas criações. A Escola articulou um parâmetro modernizante que visava criar uma linguagem funcional que se despisse de toda a tradição clássica, onde qualquer ornamento deveria ser eliminado em prol do princípio em que a forma seguia sua função. Para tanto a Escola da Bauhaus se apoiou fundamentalmente nas teses gestálticas como fundamentos para suas criações. ${ }^{48}$ Estas teses descrevem e caracterizam a constituição elementar das formas e foram tais leis gestálticas de fechamento, de boa-forma, de continuidade, entre outras, que nortearam a estética que a escola desenvolveu. ${ }^{49}$

\subsubsection{As designações gestálticas na tese de Pedrosa}

As leis da forma descritas pela psicologia da gestalt, no entanto, não são produtos da imaginação criativa dos artistas, são leis objetivas, observadas e descritas a partir de estudos baseados no empirismo da psicologia experimental. Formam assim um esteio científico para a arte e fornece-lhe condições e parâmetros para se desenvolver dentro de uma regularidade prevista. As leis fundamentais da forma constituem as combinações espontâneas no plano sensorial perceptivo no homem e permitem uma aproximação com as reações implícitas que ocorrem no contato com a arte. Tais leis resumem-se em fatores de reação sobre o que afeta a percepção e estes sistemas fisiológicos espontâneos obedecem às leis estruturais de organização que são: Distância, Semelhança e Boa-forma, além dos mecanismos da relação figura-fundo, como diferenciação e clausura.

Os processos psicológicos demonstrados pela teoria da gestalt atribuem estatuto de cientificidade para a pretensão autonomista do fenômeno artístico ao enquadrar-lhe em uma sistemática empírica que pode ser comprovada através de hipóteses e demonstrações. Assim

\footnotetext{
${ }^{48}$ Com relação ao método de ensino da Bauhaus, destaca-se também, que não se ensinava História da Arte na Bauhaus durante os primeiros anos de aprendizado, porque se acreditava que a criação deveria ser norteada por princípios racionais ao invés de ser orientada por padrões herdados do passado. A adoção desta postura curricular vai ao encontro das aspirações gestálticas, que privilegia a "experiência primeira" com o objeto e a desvincula das informações imagéticas e sensitivas trazidas pela memória. O aluno então tinha aulas de história, somente após três ou quatro anos de estudo, pois assim não iria influenciar suas criações.

${ }^{49} \mathrm{O}$ princípio norteador do estilo desenvolvido pela Bauhaus foi o "elementar de cada forma associado à sua função". Este elementar, no entanto, somente pôde ser definido pela psicologia da percepção, que desenvolveu uma teoria sobre o funcionamento do sistema perceptivo humano a partir de suas observações empíricas. De modo geral, os estudos gestálticos buscavam dissecar o objeto em suas formas mais básicas e orgânicas.
} 
desta forma, a arte "perde seu complexo de inferioridade e passa a viver em pé de igualdade com a ciência, a religião, a política, etc...”. Uma das grandes contribuições da psicologia da forma foi a de demonstrar a existência de leis estruturais que organizam a visão e a percepção do mundo que nos cerca. ${ }^{50} \mathrm{O}$ interesse de Pedrosa por estas questões pode ser atribuído à capacidade de melhor compreender a arte que contém estas leis que "empiricamente e intuitivamente os artistas vêm aplicando ou desenvolvendo desde os primórdios do fenômeno artístico".

Sobre a especificidade do conhecimento artístico, pode-se questionar o que de fato distingue um objeto artístico de um objeto do cotidiano. Esta questão remonta sua lógica à própria origem da forma na obra de arte, e quais suas atribuições definidoras. Ao investigar estas inquietações correlatas, Herbert Read busca este conceito definidor e reafirma uma inclinação natural do universo artístico à organização gestáltica, diz ele:

Há duas possíveis hipóteses que poderiam levar-nos no sentido de uma explicação das origens da forma estética. A primeira poderia ser chamada de naturalista, ou mimética, a segunda talvez de idealista. Segundo a primeira hipótese, todos os desvios formais em relação à eficiência são devidos à imitação, consciente ou inconsciente, de formas encontradas na natureza; de acordo com a segunda hipótese, a forma tem significação própria, isto é, correspondente a uma necessidade psíquica interior, expressando um sentimento, que não é necessariamente determinado; pelo contrário, é com frequência um desejo de refinação, clarificação, precisão, ordem. ${ }^{51}$ (READ, 1965,p.73)

Ao buscar as origens do fenômeno artístico, Read identifica uma "necessidade interior" do ser humano em desenvolver características nos objetos, que não apresentam utilidade prática efetiva, mas que correspondem a uma dimensão, consciente ou inconsciente, de responder, ainda que intuitivamente, às leis de organização da forma. Estas leis

\footnotetext{
50 Vários artistas nas décadas de 1910 e 1920, sobretudo os que desenvolveram uma estética abstrata, se detiveram em investigações teóricas com o objetivo de descobrir as estruturas elementares da arte. São exemplos seminais os estudos de Kandinsky e Theo Van Doesborg, pois em suas pesquisas descreveram os elementos estruturais da pintura como a linha e a cor. As teses, tanto de Kandinsky, como de Paul Klee, outro exemplo importante nestas investigações, valeram-se das postulações da psicologia da forma, para apurarem a percepção e dissecarem o espaço pictórico a partir de seus componentes estruturais. Sobretudo Kandinsky, desenvolveu uma teoria artística baseada no domínio das formas e na teoria das cores. A partir desta relação o artista estabeleceu um sistema de cores e sequências, correspondências das cores e das formas e relações entre as cores e entre cores e o espaço. Kandinsky percebeu que, por trás de sua pintura, estava o que realmente lhe interessava, ou seja, o equilíbrio instável entre elementos opostos, uma vez que tal equilíbrio era dado pela percepção visual e seus requisitos funcionais. Outro artista importante nestas investigações foi Piet Mondrian que desenvolveu seu neoplasticismo com padrões de linhas e cores, a partir de estudos gestálticos que lhe forneceram instrumentos teóricos e organizacionais para sedimentar conceitualmente sua dinâmica espacial e desenvolver uma linguagem estética que decodificasse outros esquemas perceptivos.

${ }^{51}$ READ, Herbert. As Origens da Forma na Obra de Arte. São Paulo: Zahar Editora, 1981. p.73 Embora a publicação original de Read seja de 1965, ou seja, em um período posterior à tese de Mário Pedrosa, nota-se a então validade dos conceitos gestálticos e sua relação epistemológica com o conhecimento do campo artístico. Pedrosa fará anotações sobre textos de Read em seu caderno de anotações. Destacamos com grifo uma das páginas em que o crítico discute as ideias deste autor sobre arte abstrata.Vide anexo E.
} 
provenientes da fisiologia cerebral atribuem ao objeto artístico uma significação biológica interior e não uma relação pragmática com o universo humano cotidiano. Segundo este autor, por definição, a gestalt enquadra-se como uma dimensão inerente ao objeto artístico. E neste sentido, para compreender então as especificidades deste objeto artístico, cabe-nos compreender o funcionamento da fisiologia perceptiva, que de maneira esquemática, influencia a intenção de produção, ou criação, do objeto artístico.

O estudo da Psicologia da forma mostra-nos que ao serem atingidos pelos estímulos externos, os sentidos da percepção tendem à melhor e possível organização da composição do todo a partir de suas partes estruturais, além de sempre buscar o equilíbrio e a simetria, que tendem à correção das irregularidades. Esta organização promovida pela fisiologia da percepção "não é fruto de atividade intelectual”, como também, "não nasce da necessidade de disciplinar dados caóticos descarregados sob nossos sentidos como um paliativo na organização da assimilação," ela é um princípio resultante das forças dinâmicas autônomas que se manifestam da dialética do todo e das partes no conjunto compositivo. As leis da Psicologia da forma relacionam-se, assim, diretamente com a arte, pois:

\footnotetext{
Permitem-nos compreender melhor o mecanismo das sensações e emoções que toda forma artística exerce sobre nós, independentemente de qualquer significado, de qualquer conteúdo exterior. Muitas de suas conclusões servem de chave para esse misterioso poder de projeção afetiva de toda organização plástica bem sucedida, de uma bela forma, uma dramática vertical, uma horizontal plácida, uma gama colorida, uma cúpula barroca ${ }^{52}$ (PEDROSA, 1996, p. 116)
}

O aporte da teoria da gestalt é conveniente ao estudo da arte, pois evidencia com clareza científica, os liames das relações das formas no objeto artístico, tendo em vista que o objeto artístico é resultado do jogo entre a autonomia das partes e a consolidação do todo. Traduzindo princípios gestálticos no campo da arte, Pedrosa diz: "a superfície de um quadro é um mundo vitalizado de forças que agem dentro dele, é um campo carregado de ação". Assim identificamos cor, valor, textura, pontos e linhas como elementos visuais de áreas que concentram ou irradiam diferentes intensidades de energia, que serão apreendidos pela percepção a partir de suas leis estruturais.

Um dos principais sentidos perceptivos é a visão ${ }^{53}$, e nela se concentra a recepção dos estímulos luminosos, puramente casuais que, ao alcançarem a retina, são organizados pelo

\footnotetext{
${ }^{52}$ PEDROSA, Mário. Da Natureza Afetiva da Forma na Obra de Arte. In: Forma e Percepção Estética: Textos escolhidos II- Otília Arantes (org.)- São Paulo: EDUSP, 1996. p. 116- Nota de rodapé

${ }^{53} \mathrm{Um}$ dos estudos mais conhecidos sobre a percepção visual é o estudo de Rudolf Arnheim Arte e percepção visual- uma psicologia da visão criadora onde o teórico aplica os princípios e as novas interpretações da psicologia moderna, em especial da gestalt, ao estudo da arte. Sua pioneira publicação sobre o assunto é de 1954
} 
cérebro em unidades espaciais significativas. Diante de uma situação ótica complexa, a visão tende a buscar a forma de unidade mais estável, buscando o equilíbrio e completando as unidades óticas ausentes. Como as leis da organização visual não permitem o caos de elementos desajustados, ou mesmo a existência de unidades isoladas, a fisiologia cerebral relaciona os estímulos percebidos e os organiza de modo a se fundirem em um todo vitalizado pelo melhor equilíbrio dinâmico para a percepção do conjunto.

Além das leis da estrutura, Mário Pedrosa assinala a propriedade dos contornos, outra característica inerente à forma, como uma inversão óptica entre figura e fundo. Pedrosa cita experiências que comprovam tal propriedade e apresenta a conclusão do estudioso Hornbostel $^{54}$ : "tudo o que olho, o que vigio ou o que manejo toma posição central diante de mim, sustém-se, redobra-se de fixidez, converte-se em objeto, enquanto o resto retrocede, esvazia-se, torna-se oco, reduz-se a fundo". ${ }^{55}$ Evidencia-se nesta afirmação o caráter relacional da visão, pois, toda imagem captada pelo sistema óptico cerebral é apreendida em conjunto, dado pela relação entre seus elementos constituintes. Ainda que o objeto seja uma única unidade, a visão estabelece uma relação entre este objeto e seu fundo. No tocante ainda à propriedade dos contornos, insere-se a subordinação das partes ao todo, que se expressam como ilusões de ótica geométricas. Tais configurações formais não se originam de causas físicas externas, mas são constitutivas das relações das partes em um todo figural e "servem para demonstrar a enorme plasticidade da percepção que subordina as partes ao todo". A

e descreve o processo visual que se desenvolve quando as pessoas criam e observam as obras artísticas. O autor articula categoricamente como a visão organiza as informações apreendidas em conformidade com definidas leis psicológicas, e assim descreve e estabelece uma psicologia descritiva da visão criadora. Para a crítica em geral, esta obra de Arnheim é conhecida como o primeiro estudo que desenvolveu a relação entre teses da psicologia e o campo artístico. No entanto, é sabido pela crítica brasileira que a tese de Mário Pedrosa é anterior à Arnheim, o que destaca o seu pioneirismo e espírito arguto capaz de tal imbricação teórica. A razão do desconhecimento e da pouca divulgação da tese de Pedrosa deve-se ao fato que, muito embora o trabalho tenha sido feito e apresentado ao concurso da Faculdade Nacional de Arquitetura em 1949, o mesmo ficou engavetado por trinta anos, tendo sido publicado somente em 1979, quando as proposições gestálticas já se mostravam superadas e insuficientes para a teoria estética vigente. Pelo retardo da publicação, o pioneirismo das articulações teóricas de Pedrosa entre arte e psicologia caiu no ostracismo e conheceu-se o trabalho de Arnheim como referência teórica inovadora para o estudo da arte.

54 Novamente encontramos outro teórico citado por Pedrosa, sem muitas referências sobre suas posturas conceituais. Na tese de 1949 há a referência a seu trabalho: HORNBOSTEL, "Ueber Optische Inversion", Psych. Forsch., I, 1921. As assertivas deste teórico são também citadas por Koffka em seus estudos. Depreende-se então, tratar-se de um nome relevante nas pesquisas da época, principalmente relacionadas ao sistema óptico de captação de imagens e a fisiologia cerebral de apreender e assimilar as informações. Tais citações evidenciam não só o interesse de Pedrosa pelo assunto, como também sua empreitada intelectual de leituras e pesquisas sobre os teóricos que abordaram esta problemática. Encontra-se citação a este teórico Hornbostel no caderno de anotações de Pedrosa,vide anexo F.

${ }_{55}$ Pedrosa em sua tese comenta vários experimentos realizados para a comprovação científica de tais propriedades físicas. O teórico Hornbostel será um dos citados principalmente por chegar às conclusões mais acabadas sobre o assunto. Mais informações em: PEDROSA, Mário. Da Natureza Afetiva da Forma na Obra de Arte. In: Forma e Percepção Estética: Textos escolhidos II- Otília Arantes (org.)- São Paulo: EDUSP, 1996. p.127-129. 
grande inovação teórica da gestalt é a tese de que a visão se faz por conjuntos, relacionados entre si por leis orgânicas, que promovem a autonomia da forma sobre a significação, atribuindo-lhe inclusive independência da forma em relação ao conteúdo. Sobre a implicação desta propriedade visual no objeto artístico, diz Gyorgy Kepes:

É necessário, para que exista uma percepção estética, não ver objetos com significados, mas formas, "todos" estruturados como resultado de relações (....) que se possa sentir o prazer de uma inscrição somente pela harmonia da caligrafia, independente do significado da palavra. ${ }^{56}$ (KEPES, 1969, apud FRACCAROLI,1952)

Neste sentido, antes de vermos objetos, primeiramente percebemos as formas em todas suas relações espaciais e cromáticas. As leis gestálticas impõem suas estruturas intrínsecas das formas e por meio delas, a nossa percepção é afetada e estimulada. Ainda que se prolonguem as linhas de uma estrutura figural, ela seguirá reconhecível e conservará intactas suas qualidades, uma vez que na forma, a estrutura global impõe sua visão, dominando subtodos e partes, ou seja, é o conjunto que determina a forma percebida e não os pontos isolados. $\mathrm{O}$ sistema é fruto de um choque de forças, e sua unidade é sempre dinâmica. Pedrosa conclui então que "não há forma sem drama; A tensão espacial é alma de tudo o que vemos", pois segundo suas propriedades, a imagem é sempre gerada pela tensão entre as forças espaciais e seu fundo e o engendramento do todo figural e de seus componentes cria movimentos visuais cada vez mais complexos. De acordo com suas propriedades, os contornos podem criar ambivalências espaciais e significações equívocas. O jogo dos componentes em uma obra de arte pode ser de tal modo combinado, que aumenta à medida que a complexidade do todo plástico cresce. Foram tais implicações do equilíbrio dinâmico das forças espaciais no quadro, que fizeram a fascinação de mestres como Da Vinci e Rembrandt. ${ }^{57}$

Estas propriedades formais atribuem autonomia ao objeto artístico, uma vez que "Arte, não se reconhece, mas se vê, seja ela organizada ou não". Assim, quando olhamos as formas

\footnotetext{
${ }^{56}$ KEPES, Gyorgy. El lenguaje de la vision. Buenos Aires: Ediciones Infinito, 1969. Citado em FRACCAROLI, Caetano. A percepção da forma e sua relação com o fenômeno artístico: O problema visto através da Gestalt. Aula no 30-Plástica III, Setor de publicações, FAU-USP, 1952. A obra é citada sem indicações de página e de ano de publicação. Pesquisou-se o material e localizou-se uma referência à esta edição argentina, que, contudo, não foi encontrada para consulta e pesquisa.Novamente assinalamos outro teórico que encontra-se indicado no caderno de anotações de Pedrosa sobre a psicologia da forma.Vide anexo G. O anexo H apresenta uma página em que o crítico discute ideias da obra de Kepes, The Language of Vision.

${ }^{57}$ Pedrosa assinala em seu estudo que estas propriedades espaciais e cromáticas foram sendo desenvolvidas pelos artistas, a partir das pesquisas estéticas, antes mesmo das teses da gestalt, muito embora não da maneira sistematizada conceitualmente como fizeram os teóricos da psicologia da forma. Desde o renascimento já se tinham indícios que a criação da ilusão de profundidade, de texturas e de expressões faciais passava pela relação entre os elementos pictóricos do espaço bidimensional. Assim, o sucesso ou não da ilusão dependia da capacidade técnica do artista de estruturar a organização dinâmica das cores e dos espaços.
} 
constituintes de uma obra de arte, e não reparamos em espaços e imagens informes, é justamente onde não há organização. Porém, são nestas áreas nebulosas, onde há inimagináveis padrões à espera que nossos olhos os captem. Em tal constatação Pedrosa recorre a mais uma conclusão de Hornbostel: "vemos as coisas, mas, não vemos os buracos que as separam”. Tal é a força estrutural do conjunto da forma que a nossa percepção não consegue distinguir naturalmente os elementos constituintes da forma, o que para tanto, se faz necessário um esforço voluntário do cérebro para perceber as partes em separado. A dinâmica linear se baseia na atividade das linhas reais e nos contornos existentes, mas também se apóia nos contornos ocultos dos intervalos, fazendo com que o movimento plástico envolva as partes num todo global, conduzindo o olhar de um estímulo sensorial a outro.

O grande problema das artes, porém, é que as pessoas dispensam pouco tempo para envolver-se com o que vêem e pouco se dedicam à análise dos elementos como partes constitutivas de um todo, pois "os homens não vêem mais com os olhos, mas com a rotina das combinações estereotipadas" e não se permitem afetar pelas propriedades pulsantes presentes na obra, pois não se demoram o tempo necessário com ela, a fim de serem apreendidas por seus processos perceptivos. Nestes termos, o espectador desatento não vê o que está olhando, mas o que pensa estar olhando. De acordo com esta idéia, Pedrosa diagnostica o estranhamento comum atribuído à arte abstrata, uma vez que esta estética desvincula-se dos padrões figurativos e de elementos sígnicos do real. O espectador acostumado aos significados "estereotipados" não encontrará repertório sensório para decodificar e ler a obra à qual fora exposto. No entanto, se o espectador envolver-se com a obra a ponto de demorar-se em sua observação, será inserido em uma nova experiência perceptiva, pois passará a perceber novos padrões e combinações espaciais e cromáticas orientados, não mais pela relação com os elementos da representação, mas pela dinâmica imposta pelas leis da estrutura do conjunto dos elementos que compõem a forma.

Nas relações entre percepção e arte, Pedrosa salienta a importância destas descobertas para os estudos da percepção e das leis que regem a visão. A psicologia tradicional entendia a percepção como propriedades visuais específicas do esquema óptico-cerebral, mas a descoberta da propriedade dos contornos mostrou que tais propriedades são dos objetos e não de nossa visão. As noções gestálticas trouxeram nova luz à maneira de compreender o funcionamento do sistema visual e modificou os conceitos da maneira psicológica clássica que "apenas serviam para colocar uma venda nos olhos do investigador que, com isso, excluía 
a possibilidade de aprender fatos da maior importância para a compreensão do mecanismo da percepção." 58

\subsubsection{O modelo gestáltico e a atribuição do significado}

Discutidas as leis da estrutura e as propriedades das formas, Pedrosa encaminha sua tese a uma orientação mais analítica. Neste sentido, as duas partes restantes de seu estudo estão dedicadas à discussão sobre "Forma e significação" e "Forma e expressão" onde o crítico debaterá algumas implicações dos conceitos da psicologia da forma no universo artístico e, mais claramente, busca delinear estes pressupostos, de modo a trazerem contribuições teóricas e práticas à análise do objeto artístico.

Inaugurada por um discurso mais reflexivo que técnico, esta terceira parte está dedicada à análise de como se processa a significação dos estímulos sensoriais percebidos pelo cérebro. Assim, embasado pelos teóricos da percepção, Mário Pedrosa questiona como é que a percepção "seleciona" aquilo a que se deve dar mais atenção, aquilo que é percebido e registrado pelo cérebro, se a percepção é algo natural, nato e não uma estrutura pensada? Se a mente registra as formas conhecidas, como pode ela registrar situações que nunca foram vividas?

Lançadas suas interrogações, Pedrosa vai pouco a pouco tecendo considerações que vão trazendo as respostas. Chega-se à idéia de estruturas primitivas, onde identifica significação de uma situação, através de outra constituição análoga, parecida. Discute o problema da ideia sobre "quando a memória exerce influência sobre a percepção, revive a experiência passada no que esta tem de comum com a atual", depreende-se que a memória é um mecanismo que armazena e acrescenta imagens ou valores, mas não os cria, de modo que a experiência e a percepção beneficiam-se da memória, daquilo que esta "considerou" mais importante registrar e selecionou como lembrança, e a isto o crítico chama de "experiência privilegiada". Esta capacidade da memória de "selecionar" fatores a serem registrados, vai gradativamente acumulando as imagens e constituindo o máximo de informações sobre a circunstância em foco. Tal processo é descrito por Mário Pedrosa da seguinte maneira:

\footnotetext{
${ }^{58}$ Pedrosa endossa a crítica às teses da psicologia clássica que entendia a visão a partir de elementos isolados que eram significados pelas associações trazidas pela memória. A Escola gestaltista apresenta outra compreensão da fisiologia visual que amplia o espectro da percepção para além daquele conhecido e associado ao real.
} 
Com a repetição da experiência, seja de um objeto ou de uma circunstância, a percepção melhora progressivamente, conclui-se que a visão se beneficia da lembrança dos precedentes. No entanto, o sujeito não tem consciência de recorrer à memória para constituir a visão em vários detalhes, o sujeito "pensa" ver melhor com a repetição, o que na verdade é um acúmulo de imagens que vão sendo resgatados pela memória, no processo de constituição da imagem, o sujeito acumula lembranças do que viu outras vezes, mas não se dá conta disto, pois imagina conhecer melhor a imagem com a repetição. ${ }^{59}$ (PEDROSA, 1996,p. 137)

O processo de apreensão é construído pelas forças internas de organização, ou seja, pelas leis descritas pela Gestalt, como propriedades intrínsecas da forma. Nesta linha, a memória não atribui um sentido àquilo que foi percebido, ela somente assimila as reações da fisiologia cerebral destas forças internas. Mário Pedrosa analisa as capacidades da memória a partir das leis da psicologia da forma. Acumulando as leis e propriedades gestálticas anunciadas nas partes precedentes da tese, Pedrosa tece várias relações entre o que é atribuição da forma e o que é atribuição da Memória.

A influência da memória imediata é sempre visível e põe-se a completar o que falta à visão ininterrupta do objeto, a partir das leis estruturais da forma. Nota-se então, que mesmo quando a memória está em ação, ainda aí as leis da estrutura se impõem, pois “quanto mais bem organizados e mais nítidos os subtodos da experiência sensorial, tanto mais perfeita a percepção". Pedrosa ainda retoma o conceito da visão por estereótipos e articula tal processo ao funcionamento da memória, diz: "na visão o olho se desloca em série de impulsos, e utiliza as pausas para organizar a visão. Não se lê letra por letra, reconhecem-se grupos por detalhes que constituem um tecido completado por uma projeção imaginária."60 Tal afirmação assinala, não uma presença impositiva da memória, mas revela a força dinâmica das estruturas intrínsecas das formas, que se impõem como conjunto, de modo que a significação buscada pela memória estará ligada ao âmbito do todo figural e não de suas partes individuais.

A memória não cria a significação do objeto e muito menos determina a existência deste, mas no momento em que o objeto é percebido a partir das forças de organizações inerentes ao

\footnotetext{
${ }^{59}$ PEDROSA, Mário. Da Natureza Afetiva da Forma na Obra de Arte. In: Forma e Percepção Estética: Textos escolhidos II- Otília Arantes (org.)- São Paulo: EDUSP, 1996. p.137- Parafraseado e comentado. Pedrosa se atém à discussão da função e atuação da memória, pois, esta problemática se enquadra em uma das críticas da psicologia gestáltica à psicologia clássica associacionista. Segundo as teorias tradicionais, a significação da visão se constitui a partir de associações com os conteúdos armazenados pela memória. Como a gestalt rejeita esta idéia, Pedrosa desenvolverá um percurso de raciocínio para explicar como a psicologia da forma compreende a formação da significação.

${ }^{60}$ Citação de Paul Guilhaume, Manuel de Psychologie, p.145. Psicólogo francês que introduziu a psicologia da forma na França. Sua obra foi largamente divulgada entre artistas e intelectuais do período. Guillaume é citado muitas vezes por Pedrosa em sua tese de 1949.
} 
esquema cerebral, a memória intensifica a experiência apreendida com o que ela tem de comum com as experiências passadas, já organizadas e registradas pelo sistema mnemônico. Ao nos depararmos com um novo quadro, o que acontece é a agregação de uma nova experiência, mas ainda assim a memória colocará em evidência a circunstância que lhe é conhecida:

\begin{abstract}
A movimentação que se dá aos nossos olhos, a luta do espaço para fazer-se notar, do fundo para tomar o lugar da figura, das forças em tensão de linhas e contornos, do movimento de expansão e do de interiorização, de avanço e recuo das cores... - Nada disso é novo, de uma nova relação com o universo, de uma nova vida: mas simplesmente como uma identificação de nossa memória com fatos, coisas ou experiências passadas. (PEDROSA, 1996, p. 141)
\end{abstract}

Pedrosa explicita nesta experiência, a relação das leis da estrutura gestáltica com a memória. Quando vemos algo novo, o processo que se inicia é o mecanismo das leis estruturais da visão para registro e reconhecimento do que está sendo visto, e neste mecanismo de reconhecimento e significação do objeto, a visão estrutura a imagem partir de suas forças internas. Ao constituir a formulação do conjunto percebido, a memória é acionada para averiguar o que há guardado na mente, decorrente do acúmulo de experiências passadas. A memória registra com maior ênfase, a experiência com que se identifica. Conclui-se então, que a mente não "escolhe" o que vai registrar, mas o faz a partir do acúmulo de experiências comuns a que é sujeita. No entanto, em arte esse "extraordinário poder da memória" se faz num sentido conservador e rotineiro. A virtuosidade do artista, porém, está na força da persistência e da repetição dos elementos conhecidos e, a partir deles, dedicar-se a criar novos padrões, que serão percebidos pelo expectador que se põe a criar junto com o artista.

A partir deste critério mnemônico, Pedrosa cita e discute a opinião equivocada, para ele, do teórico Thurston ${ }^{61}$ que exclui da obra de arte todas as soluções novas, originais, para consagrar apenas as formas já carregadas de significação. Ele não concebe outra maneira de perceber as coisas e toma a contemplação artística como uma evocação de imagens representativas, já vistas e reconhecidas. Thurston argumenta em favor de um artificialismo da visão comum, pois para ele "nós não olhamos, não vemos; nós lemos, traduzimos, reproduzimos.” Pedrosa já ciente das conclusões do teórico, replica de maneira irônica:

\footnotetext{
61 THURSTON, C. The Structure of art, op. cit., p.37. Ao tratar desta problemática da memória, Pedrosa encontrará neste autor um contraponto da visão da psicologia clássica que se apoia no conceito associacionista da memória a partir de elementos conhecidos. Neste sentido, o teórico investe no naturalismo como única forma plausível de conhecimento, uma vez que, segundo suas idéias, a natureza do real é a única forma de experiência que se pode registrar na memória.Sobre esta questão da experiência, Pedrosa apresenta anotações em seu caderno. Vide anexo I.
} 
Diante do fato, o nosso autor resigna-se, procurando ao contrário tirar proveito do vício, agravando-o no domínio precisamente onde é mais nefasto. Tudo se resume para ele em captar a atenção fugaz do observador, e como a prende? Pela representação de um objeto natural. (Ibid, p.142)

Segundo as conclusões de Thurston, o naturalismo é a única forma de reconhecimento do objeto artístico, e a inovação do artista estaria em explorar a multiplicidade de detalhes de um objeto. Como uma louvação ao pressuposto do paradigma clássico, o teórico define o naturalismo como "a maior invenção da história da arte.” A esta sentença, Pedrosa responde com fina ironia e desconfiança. Diz ele: "não nos interessa, porém, o seu entusiasmo, nem se tirou patente pelo invento. Este é apenas mais um instrumento de conservadorismo artístico".

Pedrosa faz uma crítica ao raciocínio e à linha associacionista de Thurston, uma vez que suas demonstrações incidem sobre a persistência e validade da estética naturalista, ou seja, reconhece como única forma de arte, a clássica, uma vez que parte do pressuposto que a mente só opera com padrões que lhe são reconhecíveis e familiares. Pedrosa o considera como defensor do conservadorismo no campo da arte, uma vez que sua tese justamente nega a possibilidade de assimilação de novos padrões artísticos, e para Mário Pedrosa este conservadorismo era o responsável pela castração criativa que acometia o meio da arte. $\mathrm{O}$ crítico se coloca contra o teórico associacionista, principalmente por defender uma estética já esgotada de padrões criativos que levara até as últimas consequências o aperfeiçoamento da representação do real e que não trazia mais interesse artístico. Segue em sua crítica ao autor afirmando: "É sua teoria expressão das mais paradoxais dessa educação verbal de que padecemos hoje", pois, para ele, a opinião de Thurston refletia claramente o dilema levantado pela arte moderna, ou seja, de vertentes teóricas que reverberavam a tensão da crise do objeto e da discussão trazida pelo paradigma moderno, que se pronunciava em oposição à imagética naturalista.

Para Mário Pedrosa, as conclusões de Thurston seriam equivocadas, pois atribuir à impressão uma significação somente manipulada pela memória e pelo hábito, é condicionar a criatividade a determinados padrões e negar ao indivíduo a assimilação de uma nova experiência, é como se o teórico admitisse não haver espaço para um novo conhecimento, para um novo padrão, senão aquele já conhecido e assimilado. Nesta linha, contribui-se para o embotamento da percepção ingênua primeira pela classificação das coisas já conhecidas, transformadas em conceitos vagos, "sem carne e sem interesse". Indignado pelas conclusões alcançadas pelo teórico, o crítico assinala a importância estética da experiência primeira, e 
nota que Thurston teria sido o primeiro a admitir o poder estético aos efeitos da imagem da percepção ingênua. Também nota a afirmação do teórico, acerca de que a mesma emoção primeira definha com o tempo, e verte-se em um conceito geral, banalizado e frio. Contraditoriamente, o próprio Thurston antes de declarar suas convicções sobre a via unilateral da percepção naturalística, teria assinalado a importância de se analisar os componentes de um objeto artístico a começar por suas formas mais elementares, mais abstratas e sem significação aparente. O teórico teria dito:

Se as figuras com que temos que começar, parecem simples demais para ser consideradas como arte, talvez seja útil lembrar que elas devem ter parecido radiosas de beleza aos primeiros homens que as desenharam (...) elas constituem o verdadeiro tronco da árvore de onde as formas intrincadas e variadas da arte moderna brotaram, num crescimento ininterrupto. (Ibid, p. 143)

Ao analisar o percurso controverso das idéias desenvolvidas por Thurston, Mário Pedrosa identifica o seu equívoco:

No entanto, (Thurston) timbra em buscar a antiga emoção evaporada onde ela não pode estar: em associações automáticas, do hábito e da superimposição incessante de camadas e mais camadas de significados estranhos e hostis às propriedades intrínsecas da forma, entre as quais o seu próprio poder afetivo (Ibid)

Assim, para Pedrosa a antiga emoção da experiência primeira, não pode estar na repetição do já conhecido, ainda que exacerbado de detalhes, não é mais novidade é acúmulo de informações já experimentadas. O nosso crítico realça que se devem ver novas formas não com o repertório do que é sabido, mas justamente abrir-se à aquisição de novas experiências, deixar-se sentir com os sentidos e não racionalizar com a inteligência, "É preciso ver as formas não com o que se sabe, mas com os sentidos simplesmente.” (PEDROSA, 1996)

Pedrosa assinala com ênfase a importância do olhar, uma vez que tal ato por si só, por suas leis estruturais, basta-se em si mesmo. A discussão localiza-se na mudança de foco sobre o que ver. Não é que a mente só assimila o que lhe é conhecido, é que até então, pouco se entregou a mente a observar o que lhe é novo, desconhecido, formado por novos padrões de composição e significação. Admite-se então, duas experiências distintas, uma de ver e outra de conhecer e construir um saber para o que se vê.

Segundo pesquisas experimentais com pacientes com problemas de visão, percebeu-se que as estruturas da visão e da memória são diferentes. Quando há uma deficiência e perturbação na organização visual das formas é que se recorre aos instrumentos intelectuais de interpretação. Concluiu-se assim que "A primeira função, a organização visual formal, não 
depende, pois da segunda (a memória); é que esta, de ordem aquisitiva, não consegue reconstituir a primeira; apenas atenua indiretamente a falha daquela." Para distinguir uma forma, para vê-la, os elementos intelectuais de cultura e de significação são dispensáveis. $O$ que se necessita é entregar-se à observação demorada, interagir-se com a própria forma a que se expõe, pois uma vez que a visão é dada pelo poder das forças internas de percepção gestáltica por meio dos sentidos, a fisiologia cerebral busca a agregação do todo, e sua significação será construída por uma atuação conjunta dada pela intuição do indivíduo e pelas qualidades sensíveis do objeto. Diante disto, o que se necessita é aprender a ver, tendo em vista que "saber" e "ver" são dois processos independentes e cognitivamente diferentes.

\subsubsection{As atribuições da Forma e a Expressão artística}

Após argumentar sobre a estrutura da visão e sua independência em relação à composição da significação, Pedrosa desenvolve a relação "Forma e expressão" que compõe a última parte de sua tese. É o conteúdo onde Pedrosa mais centra a questão na problemática artística e discute mais claramente as proposições da gestalt aplicadas à arte.

Mário Pedrosa cita constatações de Max Wertheimer ${ }^{62}$, sobre experiências com figuras abstratas, nas quais verificou que a organização das figuras se dá de modo espontâneo e de acordo com as qualidades intrínsecas das formas. As figuras sejam quais forem sempre estarão sujeitas aos sistemas de estruturação da visão e da própria dinâmica interior da obra, seguindo seus ritmos e a tendência natural das formas de recorrerem à organização e correção das irregularidades.

A percepção é a grande responsável pela estruturação dos estímulos que recebe. Contudo, ela "não nasce de um caos ao qual impõe ordem, graças ao auxílio de experiências anteriores", tais processos são intrínsecos ao esquema perceptivo de cada indivíduo como leis naturais. Sendo assim, assemelha-se às leis físicas, que existem no universo como tal. De

\footnotetext{
${ }^{62}$ Teórico da psicologia experimental que desenvolveu as pesquisas de sistematização das teses da gestalt. Em 1921 publica Psychologische Forschung (A pesquisa Psicológica), juntamente com Köhler, Koffka, Golsdtein e Gruhle, onde inicialmente apresenta os paradigmas conceituais desta vertente e desenvolve as leis estruturais da forma. No ano seguinte, Wertheimer publica Untersuchungen zur Lehre von der Gestalt (Investigações dos ensinamentos da Gestalt), onde aprofunda teses sobre esta teoria. É um dos teóricos que compõe a escola alemã de psicologia da forma, juntamente com Wolfgang Köhler e Kurt Koffka, com os quais trabalhou na Universidade de Frankfurt.
} 
modo, que a percepção não é um produto da atividade intelectual, é antes uma estrutura natural de todo organismo.

Como uma capacidade intrínseca da percepção, a sistemática estrutural das forças internas da percepção tende a organizar estímulos recebidos da melhor maneira possível. Foi por causa da força agregadora desta propriedade, que Koffka ${ }^{63}$ designou a percepção primeira como artística, por ser conjuntamente a fonte da organização estética e por dispor dos mesmos mecanismos das primeiras reações artísticas, ou do que Pedrosa chamou, em sua tese, de “experiência primeira". 64

Esta "experiência primeira" aproxima-se do conceito de "experiência estética",tal como o entende a teoria da recepção posteriormente. Este conceito, Pedrosa o tangencia como termo, mas o mesmo será desenvolvido somente nas décadas de $1960 .{ }^{65}$ Tanto a "experiência primeira" quanto a "experiência estética" são o momento do encontro do espectador com a forma, em que as estruturas das forças internas do cérebro operarão fisiologicamente pela melhor apreensão desta percepção. Nestes termos, pode-se afirmar que toda percepção é artística. Tendo em vista esta concepção, por que então, precisamos de arte? Para tal questão, o crítico assinala que nem sempre o organismo dispõe de perfeitas condições para realizar uma organização plena e completa, como a obra de arte exige. Assim, a obra de arte é realizada precisamente com o objetivo de, uma vez completa, servir de fonte de estímulo especificamente seleto por seus efeitos, ou seja, estimular a percepção para novas vivências e sensações. Toda percepção primeira é fonte da organização estética, pois redimensiona todos os estímulos que são vistos e sentidos e os sistematiza em experiência e aquisição de conhecimento, que são então, assimilados pelo cérebro.

Deste modo a arte torna-se um elemento vivificador daquela "experiência primeira" que vai sendo amortizada pela quantidade e velocidade com que assimilamos novas informações. A arte coloca-nos diante de uma situação de estranhamento e reflexão, por via de um distanciamento do cotidiano e nos propõe uma reflexão sobre o real, articulando uma "estrutura idealmente perfeita", que deveria ser comum e corriqueira a toda experiência, mas

\footnotetext{
${ }^{63}$ Teórico da psicologia experimental que endossou as pesquisas de sistematização das teses da gestalt. Em 1935 publica Os princípios da Psicologia da Gestalt, onde desenvolveu os paradigmas conceituais desta vertente e apresentou as leis estruturais da forma. É um dos teóricos que compõem a escola alemã de psicologia da forma, juntamente com Wolfgang Köhler e Max Wertheimer, com os quais trabalhou na Universidade de Frankfurt.

${ }^{64}$ Este conceito de "experiência primeira" é fundamental para a teoria gestáltica, pois é o contato primeiro com a forma e suas disposições circunstanciais, que influenciarão as relações estabelecidas pelas forças estruturais do sistema motor cerebral para assimilar tal percepção.

${ }^{65}$ Estes conceitos serão posteriores às ideias de Pedrosa. O conceito de "experiência estética" será detidamente analisado e resignificado com o advento da chamada Arte Contemporânea, onde a construção da obra e a participação do espectador assumem papéis constituintes. Hans Robert Jauss desenvolverá o conceito com atribuições específicas da arte deste período, como também pensando, em especial, a literatura. Vide nota 42.
} 
que vai sendo desgastada pela postura desatenta diante de tudo o que nos chega à percepção. A dimensão do objeto artístico permite uma "retificação consciente" das estruturas que nos passam desapercebidas cotidianamente, e nos despertam para o encontro atento e espontâneo com situações que revivem nossa percepção de maneiras criativas e lúdicas, nos colocando em contato direto com a descoberta e a reflexão. É esta situação desinteressada e fortuita que Pedrosa chama de "autêntica espontaneidade primeira".

O que os teóricos da gestalt querem assinalar é que o contato diferenciado com a arte possibilita tal experiência justamente por conta das propriedades intrínsecas da forma, ou seja, da capacidade de afetação dada pela própria natureza do objeto artístico, ou da forma da obra de arte. Uma constatação que é própria desta corrente é a de que certas formas têm a capacidade de afetar a percepção e promover uma experiência sensível sobre o ego ${ }^{66}$. Tais relações entre os objetos e o ego podem parecer naturais, pois nenhuma forma ou estímulo passa incólume a uma formulação afetiva das estruturas psíquicas do espectador. Assim, as sensações despertadas por determinada forma ou cor, estão relacionadas às propriedades estruturais dos próprios objetos que são "decodificadas" pela percepção de acordo com sua reação sensorial e afetiva.

Nesta relação entre os objetos e a forma de percepção, Mário Pedrosa encadeia três grupos distintos. Um primeiro relacionado às qualidades inerentes ao objeto que são inegáveis, tal como a qualidade de ser redondo em um objeto de forma esférica. Um segundo grupo que se estabelece pelas relações entre os objetos, ou formas, ao que o crítico chama de "qualidade de ordem temporal" como a diferença entre um tom isolado e uma melodia composta de vários sons. Por fim, o terceiro grupo está destinado especificamente às sensações de sentimentos, e que são designadas pela expressão fisionômica que as demonstra. No entanto, ao arrolar estes grupos de formas e sensações, Mário Pedrosa assinala que o seu interesse no objeto artístico advém de outra natureza. A questão desta última parte da tese não é averiguar a percepção de sensações comuns, mas o seu foco de interesse é especificamente sobre a percepção do objeto artístico. Diz Pedrosa: "O objeto de arte é o nosso objeto

\footnotetext{
${ }^{66}$ Mário Pedrosa refere-se a ego, porém não explicita qual o conceito de ego a que está se referindo, se é o ego psicanalítico de Freud, ou o conceito arquetípico de Jung. Embora por vezes Pedrosa tenha criticado as duas vertentes, neste contexto, o uso do conceito parece aproximar-se ao conceito junguiano de ego, devido as associações entre estruturas reais e o universo interior sentido. Reconhece-se aqui uma deficiência com relação a um aprofundamento maior deste conceito, por carência de domínio do tema. No entanto pareceu-nos importante assinalar esta questão que pode vir a ser desenvolvida em outra ocasião.
} 
fenomênico presente. Trata-se de conhecer as qualidades do seu todo, as qualidades formais que o compõem.",67

Antes de seguir em sua análise, Pedrosa evidencia uma ressalva. Aponta que não deseja constituir uma psicologia da arte, uma vez que a considera demasiado subjetiva por deter-se à análise psicológica no momento de criação do artista. Pedrosa esclarece que quer fazer incursões por outro domínio, pois seus propósitos são outros, e assim esclarece seus objetivos:

Interessa-nos, sobretudo, a obra de arte, o objeto de arte. Este existe independentemente, e são suas qualidades intrínsecas, suas propriedades formais que o distinguem como um todo à parte, com existência própria. E é através dessas qualidades estruturais que ele exerce influência sobre nós. Este é o nosso problema. (PEDROSA, 1996, p. 149)

Assim como já desenvolveu as idéias gestálticas em outros momentos da tese, o que o crítico deseja é atrelar tais conceitos à percepção do objeto artístico. Deprecia a idéia de aterse ao universo interior do artista no momento da criação artística, pois julga não encontrar aí nada que de fato o faça compreender o objeto de arte, e rejeita a idéia de averiguar uma psicologia do artista. Também não se interessa pelo espectador, uma vez que o objeto artístico existe independentemente deste, e assim igualmente rejeita a idéia de uma psicologia do espectador. Todavia, ao interessar-se pelo objeto artístico, assinala ser preciso então uma psicologia da obra de arte, como um campo de estudos que de fato se interesse pelas questões inerentes e pertencentes à obra de arte, enquanto um todo em si mesmo.

Como metodologia de análise o crítico assinala a escolha da psicologia da forma como teoria base para seus estudos, a fim de não incorrer ao subjetivismo unilateral como elemento essencial no entendimento do objeto artístico. Para escapar de uma designação valorativa, o crítico procura definir o que se entende por objetivo e subjetivo, embora os dois conceitos sejam circunstanciais e incompletos. Convencionou-se definir por objetivo algo que existe de maneira independente e externa à mente e às sensações humanas. Em contrapartida, define-se subjetivismo como tudo o que está relacionado a sensações, emoções e opiniões humanas. Contudo, além destes dois conceitos Pedrosa aponta ainda um terceiro nível de coisas que são ao mesmo tempo subjetivas e objetivas. É o caso, por exemplo, dos sons e cores, que subjetivamente dependem dos indivíduos para serem percebidos e concomitantemente são

\footnotetext{
${ }^{67}$ PEDROSA, Mário. Da Natureza Afetiva da Forma na Obra de Arte. In: Forma e Percepção Estética: Textos escolhidos II- Otília Arantes (org.)- São Paulo: EDUSP, 1996. P. 149. Neste momento da tese, Mario Pedrosa chega ao fulcro de seu interesse pela teoria gestaltista. Sua questão é compreender como o ser humano percebe e assimila a obra de arte? Qual é a especificidade do objeto artístico que diferencia esta produção das experiências comuns do cotidiano? Nesta investigação, constrói um caminho de alicerces para assim edificar suas teses sobre sua problemática. Após arrolar as teorias gestálticas e explorar seu esquema funcional, suas implicações conceituais e, assim, munido de instrumentos técnicos e teóricos, Pedrosa chega à abordagem de sua questão.
} 
objetivos enquanto corpos físicos, assim são eles subjetivos em um sentido, mas também objetivos em outro. Segundo o raciocínio de Pedrosa podemos designar duas categorias de subjetivo e duas de objetivo. Uma primeira definição que classifica as coisas e qualidades como "pertencentes ou não ao ego" e uma segunda definição de subjetivos porque dependem do ego e objetivos porque não dependem.

Estas definições parecem despropositadas, no entanto são de vital importância para a força do argumento de Pedrosa. Uma vez que o crítico quer mostrar como a percepção funciona de modo objetivo, independente da subjetividade do espectador, tais diferenciações são fundamentais para a articulação e comprovação de seu argumento. Ao reportar-se à obra de arte, Pedrosa delineia duas dimensões em relação ao seu espectador, "a obra de arte é assim fenomenologicamente ${ }^{68}$ objetiva e funcionalmente subjetiva”.(PEDROSA, 1996, p. 152) Além destas classificações, a obra de arte é ainda um objeto físico, podendo também ser dimensionada como funcionalmente objetiva, uma vez que é por meio de sua existência física que se relaciona com a percepção, e é somente por meio dela que pode ser conhecida pelo individuo e passa a fazer parte de seu ego. A gestalt, neste sentido, trouxe um sólido aporte teórico na medida de tornar conhecido o mecanismo de relações entre forma, percepção e ego, como estruturas fisiológicas naturais do organismo humano.

A questão da legitimidade desta idéia é tão importante para Mário Pedrosa, que é reiterada por ele diversas vezes: “A objeção de falta de objetivismo que se levanta nesse domínio, há de levantar-se em todos os domínios da atividade mental do homem.” Pedrosa deseja com seu estudo, imprimir à arte uma investigação com teorias e métodos e estender à disciplina Estética a legitimidade de ciência empírica, com a mesma credibilidade daquelas

\footnotetext{
${ }^{68}$ Em sua tese Da Natureza Afetiva da Forma da Obra de Arte, Pedrosa se atém ao estudo dos processos gestálticos de percepção por estar atrelado principalmente às preocupações da arte concreta, de modo à constituir sobre ela uma teoria crítica coerente sobre as relações espaciais e cromáticas da composição bidimensional. No entanto, neste trabalho Pedrosa já entrevê uma afinidade teórica com a fenomenologia, que lhe dará instrumentos teóricos sensitivos para além do mecanicismo da forma. Embora dedique um estudo aprofundado às questões inerentes à Gestalt aplicadas à arte, a finalização da tese de 1949 sinaliza uma tendência de perfilamento às teses da fenomenologia, sobretudo às relacionadas à dimensão intuitiva, trazida por esta linha teórica, como um complemento ao entendimento da psicologia da forma. Pedrosa ingressará, de fato, pela fenomenologia, na década seguinte, a saber, 1960, quando se dirige para a arte neoconcreta e se atém a outras preocupações que não estavam presentes na teoria concreta da década de 1950. Já entre os neoconcretos, as pesquisas estéticas extravazavam a dimensão do quadro para assumir o espaço do ambiente, onde o corpo do espectador assume parte no "fenômeno" da obra de arte como um todo, e não somente o espectro da percepção visual, como o era nos processos gestálticos. Assim, ademais das contendas entre os artistas paulistas X cariocas, concretismo e neoconcretismo tanto em São Paulo, quanto no Rio de Janeiro, assinalou-se uma imersão nas teses gestalticas entre os concretistas e a subsequente adesão às teses da fenomenologia que ampliavam o espectro da percepção para além da categoria visual, entre os artistas neoconcretos. Em suma, a teoria crítica de Pedrosa nestas duas décadas agregou um arcabouço teórico e filosófico que instrumentalizou-o para uma crítica densamente embasada e esteticamente sofisticada ao associar a gestalt, o pensamento de Bergson, a fenomenologia de Merleau-Ponty e a estrutura simbólica da fenomenologia de Ernst Cassirer, e de Susanne Langer.
} 
atribuídas às ciências naturais. Assim, com o suporte empírico das teorias da psicologia da forma, se a ciência estética for questionada quanto à legitimidade científica de seus postulados, todas as demais ciências também o serão, por mais científicas e empíricas que forem. É certo que Pedrosa admite a dimensão subjetiva da arte, e assume a relatividade quanto às impressões pessoais. No entanto, assinala uma diferença substancial entre admitir a dimensão relativa de opiniões e coadunar com a idéia que nega o campo artístico como conhecimento objetivo com especificidades intrínsecas.

Após ater-se à antinomia objetividade x subjetividade no campo artístico, o crítico retoma as análises da obra de arte em sua relação com o indivíduo. Tal relação passa indubitavelmente, pela dimensão da percepção, que "transforma" a obra de arte de objeto físico em status de objeto percebido. Este objeto físico traz em seu bojo dois pólos, onde de um lado reside o criador e de outro o espectador, e a obra de arte como objeto realizado "é o ponto terminal da ação do artista, mas o ponto de partida do apreciador", desta maneira a obra de arte coloca-se na relação entre duas instâncias, entre dois egos. No entanto a obra de arte não se define por aquilo que aconteceu na alma do artista, ela tem uma dimensão a mais do que matéria física. A obra de arte tem uma peculiaridade, que os objetos comuns não têm. A arte comunica. A sua peculiaridade reside na relação entre o criador e o espectador, onde acontece um fenômeno de comunicação, de formulações e sentidos entre os universos psíquicos envolvidos, e o ponto de intersecção desta comunicação é o próprio objeto artístico, que se coloca entre dois egos, tanto na relação obra de arte-criador, quanto na relação obra de arte-espectador.

Estas relações, porém, não podem ser definidas por uma análise que busque descrever as emoções despertadas pela obra de arte, pois tal "ilusão introspeccionista" não chega ao cerne destas relações, que na verdade se estabelecem em dimensões muito mais estruturais, na relação entre o objeto e o ego. Pedrosa aponta que várias teorias tentam explicar esta relação. Uma delas se baseia na lei de ação e reação, onde cada estímulo recebido responde com uma reação, que pode ser agradável, ou não, ao organismo. Outra teoria aplica-se na idéia de que a relação é antecedida por um desejo preexistente, onde a obra de arte despertaria no espectador a satisfação de algum desejo profundo, oculto neste. No entanto, recaindo no extremo subjetivismo emocional, tal teoria se afasta do paradigma da experiência estética, enquanto percepção da estrutura intrínseca da forma no objeto artístico. Na terceira teoria sobre a catarsis, enfoca-se o "efeito purificador" da obra de arte sobre o ego, no sentido de servir ao ego em alguma demanda que este objeto artístico poderia suprir-lhe. Esta teoria, assim como a 
segunda, se equivocam por valorizarem sobremaneira a questão emocional e por considerarem as relações com a arte somente como experiências subjetivas.

Para além destas teorias, o crítico assinala que a "chave da emoção artística está nas propriedades intrínsecas do objeto de arte, ou seja, na relação perceptiva entre a forma do objeto e o ego do espectador ${ }^{69}$. Até então as teorias que relacionavam obra de arte e as emoções despertadas por ela, estavam equivocadas, pois, tomavam somente o dado fenomenológico $^{70}$ do ego diante do objeto artístico. Faltava-lhes uma averiguação mais profunda que de fato, estruturasse esta relação ego-objeto de arte, de modo a não parecer automática e trivial. Diante disto, Pedrosa reitera que a teoria gestáltica veio preencher esta lacuna, onde "a reação emocional não é uma reação qualquer, contingente, ou automática; ela é um resultado inteligente das propriedades do objeto", dessa maneira, a reação expressa pelo ego diante de um objeto artístico não reside em uma pulsão interior do ego, mas é uma característica componente e inerente à forma do objeto de arte, a reação do ego dá-se em virtude das qualidades que a obra de arte aciona. ${ }^{71}$

A partir desta discussão entre reação emocional e ego, Mário Pedrosa vai perscrutar a origem da percepção na criança e questiona a idéia que a percepção humana primeira, ou seja, no recém-nascido, derive de um caos impressionista, aonde a experiência vai gradativamente atribuindo uma percepção ordenada do mundo. Koffka discute que a criança distingue as fisionomias de seus pais, o que não seria um estímulo elementar, mas um conjunto complexo de informações para reconhecer e identificar tão primariamente. Ao concordar com esta observação, Pedrosa acrescenta: "para a teoria do caos, o rosto humano deve ser quanto há de mais complexo e caótico; um formigar de sensações de cor e de claro-escuro (...)" (PEDROSA, 1996, p.158), pois perceber a feição dos pais não parece nada simples e elementar, o que então suscita a existência de outro processo no universo psíquico da criança que atue no desenvolvimento da percepção e da aquisição de experiências.

Ao longo de seu desenvolvimento, o bebê percebe expressões e, desde muito cedo, consegue distinguir um rosto afável de um rosto "mau". Assim, o crítico conclui que "para a

\footnotetext{
${ }^{69}$ Em nota de rodapé, Mário Pedrosa discute o problema da forma entre os teóricos alemães. Desde a exacerbação da subjetividade no universo romântico até o "culto schilleriano da forma" e a crítica anti-romântica de Kant. Destaca que Dilthey, em sua obra "Imaginação Poética" de 1887, faz um panorama desta discussão e assume ser de interesse da psicologia os aportes teóricos sobre a questão da experiência estética. As reflexões de Dilthey marcaram o início do novo movimento formalista alemão na passagem do século XIX para o XX.

${ }^{70}$ Vide nota 68.

${ }^{71}$ Esta colocação evidencia a vinculação da gestalt com a psicofísica, uma vez que atribui ao objeto artístico uma dimensão de ação e reação com seu espectador. Apresentada desta maneira, a interpretação gestáltica do fenômeno artístico deixa entrever suas fissuras epistemológicas, pois ao lograr atribuir à arte um esquema elucidativo objetivo, em certos momentos, o modelo parece engessar o atributo artístico de modo à restringi-lo à um mecanismo programado e pré-determinado, como se este pudesse ser plenamente previsível e controlável.
} 
criança recém-nascida a expressão é a tradução fenomenológica das primeiras estruturas e formas que ela distingue". Deste modo, a criança percebe aquilo que lhe afeta mais diretamente, e tais fenômenos, ainda que complexos, lhe são estruturas afetivas que primariamente serão as bases objetivas sobre a qual a criança desenvolverá sua percepção e assimilará suas próprias experiências.

Uma mesma relação entre uma forma expressiva e um fenômeno afetivo pode ser encontrada na arte. Assim, o fenômeno artístico apresenta a mesma mediação que o poder fisionômico exerce sobre as crianças. Assim como estruturas inerentes às fisionomias dos pais são assimiladas pelo mecanismo perceptivo do recém-nascido, em arte, a assimilação das estruturas intrínsecas do objeto é natural, aquém de todos os recursos de conceituações abstratas e intelectuais, a associação não é externa é processada pelo próprio mecanismo do individuo e não agregada por elementos estranhos a ela.

Pedrosa vale-se ainda da comprovação empírica da psicologia infantil e animal para embasar suas verificações, pois se tais estruturas são naturais, devem ocorrer do mesmo modo invariavelmente como ocorrem nas crianças e nos animais. Assim, a idéia de que a aquisição do conhecimento do objeto artístico viria pela via intelectiva, esvai-se sem fundamentação e verificação empírica. A reação do organismo diante do fenômeno artístico é tão natural, quanto a reação de um músculo ao movimento. A especificidade do conhecimento artístico, no entanto, engendra uma outra dimensão, a subjetiva, o que provoca a impressão indistinta de corresponder à uma reação externa. Há nesta especificidade uma dimensão objetiva, natural como reação intrínseca do organismo e a dimensão subjetiva que é assimilada pela cognição do individuo. Diante destas dimensões faz-se necessário, porém, assinalar a diferenciação:

É difícil, muitas vezes impossível, separar nos termos aplicados à emoção os que designam exclusivamente a impressão subjetiva ou os sintomas objetivos. Os dois se exprimem pelo mesmo termo; daí a ambivalência adquirida deste, ora servindo para um ora para outro. Essa explicação dupla, porém, não se dá porque os dois aspectos sejam contíguos, mas porque são semelhantes. (PEDROSA, 1996, p. 161)

Na experiência estética as duas dimensões, a objetiva e a subjetiva, atuam juntas, mas não dizem respeito à mesma natureza, são de parâmetros distintos com mecanismos diversos. A forma de expressão, por mais desconhecida que seja, traz em seu bojo uma estrutura intrínseca que advém da dimensão objetiva. Esta será apreendida pela percepção, a qual lhe atribuirá uma significação. A própria constituição do significado obedecerá aos padrões naturais das estruturas trazidas pela forma do objeto percebido. A dimensão subjetiva entra 
em um segundo plano, no modo como aquilo vai afetar e ser registrado na memória pelo ego. Não é necessário projetar nossas próprias experiências sobre a forma ou expressão percebida, ela tem em si mesma, um sentido. A lei da gestalt estabelece que "os objetos têm por si mesmos, em virtude de sua própria estrutura, um caráter próprio, independente de toda experiência anterior do sujeito que os percebe", assim, não são as experiências individuais que possibilitam ao sujeito adentrar na emoção ou na forma expressa pelo outro, mas tal apreensão acontece por si só, de maneira autônoma, de acordo com suas próprias propriedades e qualidades formais que são percebidas e assimiladas pelo cérebro como tais. As experiências individuais podem "enriquecer" a compreensão elaborada da forma à que está exposta, mas são, porém, um adicional às qualidades da forma ou das emoções que se bastam por si mesmas.

Com o intuito de melhor esclarecer a tese de reações naturais a determinadas formas, Pedrosa recorre novamente às observações empíricas de $\mathrm{Köhler}^{72}$ em experimentos com chimpanzés. Os animais ficaram em um cercado e diariamente eram expostos a determinados objetos e anotavam-se as reações expressas. Observou-se que os animais demonstravam medo quando viam animais grandes e répteis. Os teóricos da psicologia associacionista e atomística diziam que tal fato se explicava por experiências ancestrais da espécie, com relação à sobrevivência e aos perigos do mundo natural. No entanto, as experiências de Köhler foram além ao expor os animais a objetos como bruxas de pano e máscaras demoníacas de tribos primitivas. O curioso foi observar que os animais entravam em pânico e afugentavam-se destes objetos. A grande questão foi explicar o pavor diante de objetos que dizem respeito à cultura humana, elementos simbólicos e que nada tem a ver com situações do mundo natural. Diante destas observações, Köhler enuncia sua questão que coloca em cheque as teorias da psicologia tradicional:

Não será admissível a hipótese de que certas formas e contornos das coisas têm em si mesmos a qualidade de enfeitiçar e de assustar, não por causa de qualquer dispositivo especial que lhes permita produzir essas reações, mas porque, dada a nossa psique e nossa natureza, algumas formas têm inevitavelmente o caráter de terríveis, outras o de graciosas, ou desajeitadas, ou enérgicas, ou decisivas? (Ibid, p. 164)

\footnotetext{
${ }^{72}$ Köhler fora um dos teóricos da Escola alemã que constituiu a teoria da gestalt. Seus estudos encaminharam-se pela linha da psicologia experimental e ficaram conhecidos por suas experiências com chimpanzés. O teórico buscava averiguar suas teorias sobre as propriedades naturais das formas, a partir de observações sobre as reações expressas pelos animais. Recorria a verificações com animais, pois buscava compreender as estruturas naturais da percepção aquém das estruturas da cultura e da civilização. Como um teórico importante no âmbito dos estudos gestálticos, Pedrosa discute suas ideias em seu caderno de anotações, vide anexo J.
} 
A partir destas questões, as teorias da psicologia tradicional são questionadas e as verificações da gestalt assumem consistência teórica. Mário Pedrosa endossa estas conclusões enfatizando a veracidade das questões da forma, pois "como explicar o fato, senão consentindo na hipótese da gestalt?”. De acordo com tais verificações, comprova-se a tese central da gestalt, de que os objetos têm qualidades inerentes que decorrem de sua forma, de sua constituição intrínseca. A reação emotiva ou afetiva diante destes objetos não é determinada por experiências anteriores do sujeito, mas associada à própria natureza da forma do objeto. Quando pensamos tal situação relacionada à experiência humana, as afirmações da gestalt parecem divagações conceituais pouco aplicáveis, porém, quando verificamos tais conclusões em experiências com animais, as conclusões são verossímeis. Mário Pedrosa assinala esta conclusão de modo contundente:

Como explicar o fato senão consentindo na hipótese da gestalt? Os objetos é que tem
constituição intrínseca, essa qualidade própria de expressar pavor. O aspecto
pavoroso não lhes é atribuído pela experiência ou por alguma associação do sujeito
com o outro objeto de origem terrível. Não é uma aquisição posterior, justaposta ao
objeto pelo observador. O aspecto fisionômico de terrível ou do pavoroso é parte do
objeto, está na sua natureza, consequência de sua forma. ( Ibid, p. 165)

Do começo ao fim de sua tese, Pedrosa explora as mesmas idéias por ângulos diversos, e todo o tempo reafirma a força do argumento das teorias gestálticas. Remetendo-se novamente ao título do estudo, a presença das palavras: natureza-forma- objeto é reincidente e contribuem para corroborar as idéias do crítico. Além destes conceitos, a discussão sobre a díade objetivo- subjetivo, coincide com questões de origem emotiva-afetiva que igualmente compõem o cerne estrutural de suas preocupações neste estudo, sobretudo, quando relaciona tais conceitos à experiência estética.

Além da questão da forma, Pedrosa atém-se ainda à discussão da expressão. Tal característica não é exclusiva aos humanos, mas estende-se também aos animais. Experiências relatadas pelos teóricos da psicologia da forma evidenciaram que os animais também tem a capacidade de entregarem-se despropositadamente a uma atividade fortuita, ociosa que não tem valor vital nenhum. Da mesma maneira, os humanos desenvolvem o campo artístico com a mesma intenção ociosa e que se enquadra em uma dimensão outra, senão aquela da sobrevivência, ou seja, remete-se a uma dimensão expressiva. Tal dimensão expressiva é primeiramente percebida pela aparência com que este objeto se apresenta à "experiência primeira" que será então captada e processada pelos mecanismos perceptivos. Como o primeiro contato com a forma se dá pela fisionomia do objeto, Pedrosa desenvolve detidamente a discussão sobre o mecanismo de apreensão e significação desta primeira 
estrutura visual no contato com a nova forma, a fim de dissecar o processo de percepção e compreender-lhe as estruturas.

A expressão fisionômica é uma das primeiras coisas percebidas por crianças e animais. Atingem as estruturas perceptivas, mesmo antes da capacidade de identificá-las, e ainda que relacionadas a uma série de circunstâncias, a memória de tempo e espaço podem se dissolver, porém a composição fisionômica resiste como percepção de uma expressão particular. Como já assinalado anteriormente, a primeira expressão percebida pela criança é a da mãe e tal impressão primeira lhe marcará o elo de uma relação afetiva por toda vida. Não somente nesta relação, como em outras seguintes como um individuo mais maduro e mesmo com a percepção mais acabada, a expressão fisionômica de um primeiro contato assinala impressões sobre o caráter, a natureza e a personalidade do individuo envolvido. Tal constatação não se relaciona a uma impressão subjetiva, mas a um conjunto dos pormenores que compõem o todo fisionômico, que está na natureza destas formas, que de um modo peculiar atingem a percepção do observador e que, de algum modo, remete-lhe a uma identidade específica. Neste nível de percepção, é possível identificar traços da personalidade da forma observada, pois além de estruturas visuais atuam também componentes intuitivos. ${ }^{73}$

Em pesquisas realizadas com diferentes grupos de pessoas com distintas qualificações psíquicas, adultos, crianças, doentes mentais, letrados, leigos onde tais pessoas eram sujeitas à julgamentos de personalidade, pôde-se constatar uma regularidade nas impressões e, de acordo com os resultados obtidos, verificou-se que certas expressões físicas parecem demarcar aspectos comuns de personalidade. No entanto, pode-se questionar se tais julgamentos estão mais permeados por projeções subjetivas, do que por características expressivas de fato. Dentre os entrevistados pela pesquisa, $77 \%$ dos resultados indicaram correspondência direta entre a expressão e a forma corpórea. Assim, verifica-se que de um modo geral as opiniões subjetivas não parecem ter exercido papel relevante, mas sim as próprias estruturas dos rostos em questão. Pela explicação gestáltica, se constata que a impressão causada e o julgamento de personalidade foram obtidos por causa das próprias estruturas das formas das fisionomias analisadas e não expressos pelas constituições

\footnotetext{
${ }^{73}$ Através das idéias e argumentos da tese de Mário Pedrosa, não é transparente a adoção do conceito de intuição e não se faz claro o emprego deste. No entanto, dado o uso do conceito na filosofia moderna alemã, da qual Pedrosa é afiliado por formação teórica, permite-nos assinalar relações entre estruturas gestálticas e intuitivas no processo perceptual. Para Rudolf Arheim o pensamento visual é ao mesmo tempo intelectual e intuitivo, pois em sua concepção a intuição é a síntese da estrutura como um todo. Como um gestaltista, Arheim assinala que a estrutura intrínseca das formas constroe a percepção, mas, no entanto, é a intuição que nos possibilita perceber e interpretar as relações entre os vários elementos de uma figura. Citação sobre Rudolf Arheim encontrada em: http://www.itaucultural.org.br/aplicexternas/enciclopedia_ic/index.cfm?fuseaction=termos texto\&cd_verbete=9 $\underline{443}$ acessado em 14/05/12.
} 
subjetivas de cada participante. Os elementos constituídos são inerentes aos objetos observados, como estruturas intrínsecas e não são atribuições do universo psíquico do observador.

Em experiências com obras de arte, pode-se constatar que as qualidades fisionômicas são características não somente de rostos, mas também de figuras constituídas de formas geométricas como em um quadro ou escultura, elas são uma constante de "todo objeto fenomênico, dentro e fora da arte". Na impressão primeira, o mecanismo do cérebro é dotado da capacidade de perceber as estruturas inerentes da fisionomia do objeto observado, e mesmo em um olhar desinteressado, a percepção absorve impressões que designam expressões. Estas impressões, muitas vezes, são associadas a uma vertente intuitiva, mas nada mais são do que as características próprias do objeto que se evidenciam.

Ao tratar sobre a questão da projeção e do objeto, ainda pelos liames da fenomenologia, Pedrosa faz alusão à teoria do Einfühlung ${ }^{74}$ e apresenta um contraponto, pois uma vez que do alemão "Einfühlung" significa "sentir com”, está associada a uma projeção do ego de quem observa sobre o objeto observado. Pensada como empatia, a teoria associa o objeto contemplado como um envolvimento com o universo interior do individuo que observa, num compartilhamento de expectativas de um sobre o outro. Neste sentido, o conceito de Einfühlung se opõe à gestalt, pois nesta as qualidades do objeto são-lhe estruturas inerentes que afetam mecanicamente o aparelho perceptivo do sujeito. Naquele, as qualidades sensíveis do objeto são uma projeção do ego do observador mesclado ao objeto.

Segundo a Einfühlung, as emoções e impressões atreladas ao objeto seriam da memória vivida pelo sujeito, que então se mesclariam as expressões verificadas no objeto. Desta forma, o sujeito participa com suas bagagens cognitivas na relação de experiência estética com o objeto, como também as "qualidades fisionômicas" estariam todas no sujeito. Confrontada com a gestalt, a teoria do Einfühlung minimiza a presença formal do objeto na experiência estética, pois se tal relação é projetada pelo ego do sujeito é de natureza puramente subjetiva e ignora as propriedades intrínsecas da forma. A questão que incomoda à Pedrosa nesta vertente é que tal teoria descreve a empatia entre o sujeito e objeto, mas não explica como e por que tais reações emotivas são despertadas no sujeito, questão esta que a psicologia da forma parece contemplar com maior fundamentação teórica e experimental.

Após confrontar as duas teorias Pedrosa parece admitir um meio termo entre ambas, pois vai falar da contemplação do objeto artístico, ou seja, a experiência estética como um

\footnotetext{
${ }^{74}$ Sobre o conceito de Einfühlung vide nota 47.
} 
encontro mediado pelas duas orientações: a gestáltica e a fenomenológica, pois "sem esta aquela fica no ar, incapaz de preencher a falha na ligação entre o objeto e as reações emocionais do ego". Mário Pedrosa parece encontrar um meio termo entre as qualidades intrínsecas da forma que atua sobre a percepção do sujeito e a contrapartida da projeção afetiva do ego sobre o objeto artístico. Ao contemplar uma obra de arte, não se pode assumir somente uma via emotiva, ou somente uma via racional. Como se está envolvido pela ação da forma e do ego, devem-se considerar as duas dimensões:

\begin{abstract}
Nessas condições, não nos fica mal assentir aos ingênuos que atribuem a ação que determinada coisa exerce sobre nós a qualidade desta mesma coisa. Os artistas modernos são, nesse ponto, testemunho não desprezível. Mas não é propriedade dos artistas sentir os efeitos das qualidades terciárias. Na apreciação de uma obra de arte, todo mundo é artista, pois se tem de colocar no mesmo plano dele. Do contrário não está vendo na estátua que contempla um objeto de arte, mas um amontoado de pedras (...) (PEDROSA, 1996 ,p. 171)
\end{abstract}

Toda experiência estética demanda a visão criativa e não somente a análise racional. Tal relação implica a afetação do sujeito pelas qualidades inerentes da forma e a resposta com a projeção do ego sobre o objeto de arte. No entanto, nem todo objeto é um objeto de arte, e como tal possui as qualidades de afetar o espectador, oficio este condizente ao artista, que se incumbe da função de realizar esta transformação de um objeto comum em objeto de arte. No entanto, os liames deste processo "é um mistério que nem a ciência, nem a psicologia decifram"

O caráter de um objeto será traçado pela intenção ${ }^{75}$ com que se olha para ele. É desta intenção que se estabelece a relação entre o observador e o objeto, é esta intenção, que a priori, se define se a relação é artística ou não. Embora a forma exerça propriedades gestálticas sobre o sujeito, é a primeira atitude do sujeito em relação a esta forma que definirá as qualidades sensíveis e emotivas decorrentes do contato com o objeto artístico. Definindo

\footnotetext{
75 A questão da intencionalidade é entendida e compartilhada de maneiras semelhantes entre a gestalt, a fenomenologia e o existencialismo. Estas linhas teóricas coincidem ainda, na discordância com relação à psicologia freudiana que assinala todo ato psíquico como instintivo. No entanto, para a gestalt e suas congêneres posteriores, com relação aos estudos da percepção, todo ato psíquico é fruto de uma intenção deliberada pela fisiologia cerebral que pode ser consciente ou não, mas que se relaciona ao grau de envolvimento do sujeito com o objeto em foco. Friederich Perls, psicólogo que desenvolveu a gestalt-terapia, escola que assimila as teses gestálticas com a psicoterapia, explicita que Todo ato psíquico é intenção, e toda intenção deve ser compreendida em seus próprios termos, e não em termos de um ato psíquico mais básico. Nestes termos, rejeita a noção freudiana de instintos e entende a libido como um ato psíquico, nem mais básico nem mais universal que qualquer outro. Conteúdo pesquisado em http://www.psiqweb.med.br/site/?area=NO/LerNoticia\&idNoticia=189 acesso em 21/05/2012.
} 
esta relação sujeito-objeto, Pedrosa mostra que, o campo de relações varia de acordo com maior ou menor grau de intensidade e de envolvimento do sujeito. Quanto maior é o envolvimento do sujeito com o objeto, maior é a afetação perceptiva que este causa sobre aquele e mais formas, cores e qualidades fisionômicas o sujeito vai identificar. Nota-se ainda que, com a projeção do ego, a resposta em relação ao objeto pode-se manifestar em reverberações emotivas e até mesmo sentimentais. A recíproca, porém, é verdadeira, pois quanto maior o distanciamento do sujeito com o objeto artístico, menor é a afetação formal e emocional, uma vez que seu aparato perceptivo não está sensível para perceber as propriedades fisionômicas da forma, sendo assim, diversas informações sensíveis passam-lhe despercebidas e tampouco o ego estabelecerá qualquer relação emotiva com tal objeto. Há ainda o sujeito que se aproxima do objeto numa relação vaga e abstrata, puramente racional, onde não se permite afetar pelas características intrínsecas da forma, e que passa pela obra somente com divagações teóricas e conceituais, que de igual modo, não se permite sensibilizar o ego, a fim de envolver-se na experiência estética.

Uma mesma situação pode ter significados diversamente diferentes aos seus sujeitos, pois toda relação estabelecida vai variar de acordo com o grau de envolvimento e de intenção de cada componente. Ao recorrer a citações de Koffka, Mário Pedrosa identifica na sociedade moderna uma relação desatenta com os objetos e situações cotidianas, e desconsideram as propriedades fisionômicas e estruturais dos objetos e as relações afetivas que tais propriedades são capazes de despertar no ego. A atual sociedade cientificista que se imagina guiar pela razão, não se deixa envolver pelas relações afetivas da forma no objeto artístico. Neste sentido, outras sociedades ditas "primitivas" possuíam esta capacidade perceptiva muito mais aguçada que a moderna. Este é um dos impasses que Mário Pedrosa identifica na arte moderna de seu tempo: "a arte é o modo específico das mais puras e desinteressadas dessas qualidades das coisas. E por isto mesmo criou-se até hoje uma quase incompatibilidade entre o nosso sistema racional e científico e o sistema qualitativo dominante na estética". (PEDROSA, 1996, p.175)

A vontade de domínio da natureza pela ciência moderna, traduzida como curiosidade científica e intelectual da cultura ocidental, resultou na perda do contato do homem com as reais coisas naturais da vida e de seu mundo. Este homem moderno esteve tão preocupado com o desenvolvimento da técnica que perdeu a capacidade de perceber as estruturas e propriedades naturais de si mesmo e dos objetos que o rodeia e onde cada vez menos tem a capacidade, ou interessa-se ao abrir à possibilidade de um contato perceptivo de uma experiência estética com um objeto de arte. 
Pedrosa encaminha no fim de seu estudo, um alerta sobre a necessidade de uma conscientização sobre as possibilidades perceptivas perdidas, que poderiam novamente ser reatadas e ofereceriam uma relação vívida com um objeto artístico de qualquer época e estilo, pois se estaria permitindo que a obra de arte exercesse o seu efeito sobre seus espectadores. A relação com o objeto artístico deve estar ligada à "experiência primeira”, às vias desobstruídas da percepção, a fim de que os objetos possam comunicar a sua mensagem através de suas características fisionômicas e propriedades intrínsecas, e não achegar-se a ele já munidos de abstrações teóricas e conceituações prontas.

Diante disto, um objeto de arte não se define por uma capacidade de satisfazer um desejo do sujeito, mas pela especificidade de suas próprias qualidades intrínsecas, sua composição estrutural que pode nos afetar por suas próprias qualidades e daí fomentar uma relação com o ego do observador. Nesta relação com a obra de arte, Mário Pedrosa reitera o argumento de sua tese:

\footnotetext{
"O poder de comando que exerce um quadro sobre nós vem de dentro de si mesmo. Todo o segredo de sua força atuante, da magia que exerce sobre nós, dessa faculdade única que é a sua de nos despertar emoção, reside em sua estrutura formal, na sua gestalt" (Ibid, p. 176)
}

A definição de um fenômeno artístico não depende de nossas emoções, o objeto de arte existe por si só, por sua natureza formal. No entanto, é esta mesma natureza formal que definirá as condições das propriedades que conduzirão à afetação perceptiva da experiência estética. Um objeto de arte antes de existir é concebido enquanto idéia por seu criador, de acordo com a percepção que este artista tem de seu mundo. No entanto, quando esta idéia é tornada objeto físico real, uma nova relação perceptiva será estabelecida com seu espectador, pois antes de constituir um arcabouço conceitual sobre o objeto de arte, o espectador será primeiramente afetado pelas qualidades intrínsecas da forma, no processo que a gestalt e Pedrosa chamaram de "experiência primeira". Daí, decorridas as implicações formais, o ego então formulará um entendimento para a forma e se projetará sobre ela. Na relação perceptiva com o objeto, um primeiro contato é objetivo e, em um segundo momento, a relação é subjetiva. É precisamente este imbricamento de dimensões que caracteriza a especificidade do objeto artístico.

No entanto o sujeito pode se aproximar do objeto artístico de diferentes maneiras. Pode haver uma aproximação analítica, quando o individuo imprime ao objeto seus próprios juízos e conceitos, no esforço de estabelecer um sentido para a forma observada. E há ainda a 
aproximação da "experiência primeira", onde o indivíduo primeiramente se entrega à observação da forma e às suas "impressões globais" e procura absorver as qualidades fisionômicas do objeto em foco. Neste sentido o objeto será mais bem percebido e compreendido quando a visão se permite entregar-se à observação atenta de sua constituição, e não na atribuição prévia de conceitos e abstrações. Neste segundo contato é que podemos identificar, de fato, uma relação de experiência estética com o objeto de arte. É nesta relação que se enquadram as verificações das teorias gestálticas, pois as formas, por si só, tem a capacidade de comunicar e o "poder" de nos afetar. Todo individuo, mesmo sem conhecimentos técnicos e científicos é capaz de estabelecer uma relação afetiva com uma obra de arte, pois ela "fala" por si mesma, "pois toda forma é um campo sensibilizado. Está carregada de afetividade", e se a obra de arte tem algo a comunicar, todo aquele que se dispõe a ouvi-la é capaz de compreendê-la.

\subsection{AS REPERCUSSÕES DA APRESENTAÇÃO DA TESE DE MÁRIO PEDROSA: O MEIO NACIONAL}

Conforme assinalado anteriormente, este trabalho de Mário Pedrosa "Da Natureza Afetiva da Forma na Obra de Arte" tinha como objetivo concorrer à cátedra de História da Arte e Estética na Faculdade Nacional de Arquitetura no Rio de Janeiro. O trabalho fora apresentado em 1949, mas fora defendido em $1951^{76}$. Os periódicos publicados no período noticiaram a defesa, como também, sinalizavam a reverberação deste trabalho no meio artístico.

O crítico de arte, Antônio Bento que era responsável pela coluna de Artes no Diário Carioca, publicou um artigo que situa-nos no contexto intelectual em que o trabalho de Mário Pedrosa estava inserido. Diz-nos Antônio Bento:

\footnotetext{
${ }^{76}$ Há divergências com relação às datas precisas de apresentação e defesa da tese de Pedrosa. Otília Arantes aponta em seu livro Mário Pedrosa: Itinerário Crítico. (São Paulo, Página Aberta, 1991.p.55.) que a tese fora defendida em 1952. No entanto, de acordo com documentos pesquisados no Acervo Mário Pedrosa na Fundação Biblioteca Nacional do Rio de Janeiro, encontrou-se uma documentação de vários periódicos que noticiavam a defesa da tese de Mário Pedrosa em 12 de janeiro de 1951, precisamente às 15 horas. Outra discordância na datação exata é em relação ao conhecimento público do trabalho. Otília Arantes cita a apresentação do trabalho em 1949, já Paulo Herkenhoff aponta o trabalho como tendo sido apresentado em 1948. In: HERKENHOFF, Paulo. Neoconcretismo: o corpus teórico. Catalogo da exposição Desenhar no Espaço: Artistas Abstratos do Brasil e da Venezuela na Coleção Patrícia Phelps de Cisneros. Fundação Iberê Camargo/ Pinacoteca do Estado de São Paulo, 2011. p.39. Podem parecer apontamentos irrelevantes para a análise do trabalho de Pedrosa, mas que consideramos necessários para aclarar o desencontro das informações.
} 
(...) Mário Pedrosa apresentou uma tese original "Da natureza Afetiva da Forma nas Artes Plásticas", versando sobre a aplicação da "gestalt". O mais curioso é que alguns dos examinadores declararam não conhecer as doutrinas a que se reportou o candidato. Comentando esse fato, o "Correio da Manhã" estranhou que esses professores tivessem afirmado ignorar o assunto e a respectiva bibliografia. E nem se preocuparam em estudar a matéria. (...) ${ }^{77}$ (BENTO, 1951)

Tal declaração evidencia a pouca familiaridade, ou mesmo, o desconhecimento da classe intelectual brasileira sobre esta vertente psicológica na teoria das artes. Esta situação evidencia também, não somente a originalidade do trabalho de Mário Pedrosa, como também o pioneirismo de sua abordagem. Apontam que as preocupações do crítico excediam às preocupações puramente descritivas para a tessitura de seus textos de crítica de arte e imergiam em um profundo interesse teórico e hermenêutico sobre as estruturas e fundamentação da arte abstrata. Em sua tese Pedrosa faz um preâmbulo para explicar o seu interesse nas teses da gestalt, vinculado à preocupação de uma análise científica do objeto de arte, como também, um interesse profundo em superar a dicotomia subjetivismo/objetivismo do campo artístico e enquadrar-lhe nos estatutos metodológicos da cientificidade. No entanto, poder-se-ia assinalar também, o caráter propedêutico de sua tese, uma vez que, somente poderia compreender a arte que o homem produz, depois de compreender o homem que a produz. Neste sentido, seu estudo figura como uma imersão pela psicofísica do esquema cerebral a fim de compreender a fisiologia da percepção. A partir de então, o crítico teria instrumentos teóricos para dissecar a relação da arte abstrata com a percepção humana e poder "falar às mentes e às sensações" em suas críticas.

No entanto suas ideias encontravam poucos ecos entre seus pares e entre a própria intelectualidade da época. Além do depoimento de Antônio Bento sobre a recepção da tese de 1949, outros relatos jornalísticos ${ }^{78}$ da defesa da tese, destacaram o desconhecimento generalizado sobre o tema. Noticiou-se que a prova do então candidato Mário Pedrosa, fora a que obteve maior assistência do concurso, com o recinto da Escola Nacional de Belas Artes repleto de alunos e espectadores interessados. A apresentação do tema por Pedrosa foi uma surpresa para a platéia e fez com que os membros da banca examinadora, recorressem

\footnotetext{
77 Bento, Antônio. A "gestalt" e os examinadores. Diário Carioca- Artes, 19/01/1951. Documento pertencente ao Acervo Mário Pedrosa na Fundação Biblioteca Nacional do Rio de Janeiro.

${ }^{78}$ No arquivo do Acervo Mário Pedrosa pertencente à Fundação Biblioteca Nacional do Rio de Janeiro, há um módulo de documentos composto de artigos de periódicos que noticiaram o panorama do evento da defesa da tese em 1951. Muitos destes artigos encontram-se sem a indicação do nome do periódico, como também, de seus respectivos autores.
} 
constantemente à consulta dos livros "para apontar as inexatidões ou temas suscetíveis de controvérsias". Um dos relatos jornalísticos entrevê a tensão da defesa:

\begin{abstract}
A opinião geral era de que M. P., crítico de arte e titular de vários cursos empreendidos na Alemanha, lançava uma tese audaciosa, e até certo ponto, desconhecida para a maioria dos ouvintes. O trabalho de interpretação psicológica da arte, exposto com vivacidade e erudição pelo candidato, era esmiuçado pelos examinadores Frei Hasselman, Jayme Coelho, Pedro Calmon, Lucas Meyhofer e Carlos del Negro. Professores e artistas procuravam contestar as maneiras pelas quais o Sr. Mário Pedrosa encarava a forma no reino da "gestalt" (...). Além disso, as inúmeras citações da tese olhadas como deficiência do candidato, são prontamente esclarecidas e localizadas pelo autor $(. . .)^{79}$
\end{abstract}

Embora se reconhecesse a originalidade do tema e de sua abordagem, a tese de Mário Pedrosa era vista com desconfiança e receio. Várias censuras foram levantadas pela banca examinadora, sobretudo, relacionadas ao estilo da escrita do candidato. Criticou-se o fato de Mário Pedrosa realizar citações livres incorporadas ao fluxo do texto, sem indicá-las devidamente com as aspas e sem assinalar diretamente a bibliografia consultada. Outras críticas se colocaram contra a repetição dos mesmos exemplos narrativos ou figurativos dos autores de origem. Apontou-se que Pedrosa poderia ter criado outros exemplos, tão elucidativos, quanto os apresentado por Guillaume ou pelos gestaltistas alemães, uma vez que "a vida cotidiana brasileira oferecia exemplos análogos". ${ }^{80}$

Mesmo com criticas tangenciais à abordagem do tema, os membros da banca examinadora, na ocasião da defesa da tese, assumiram seu desconhecimento do assunto e reconheceram ser Mário Pedrosa um grande e erudito crítico de arte. Diz o artigo da época:

\footnotetext{
${ }^{79}$ Artigo de periódico intitulado "Natureza afetiva da Forma nas artes plásticas" datado de 13/01/1951, sem indicação do autor e no jornal. Artigo pertencente ao módulo de documentos citado na nota 78 .

${ }^{80}$ Esta citação encontra-se no artigo Mário Pedrosa na Faculdade Nacional de Arquitetura. Tribuna da Imprensa, 14/01/1951. Este artigo apresenta de maneira cômica os comentários das arguições da banca examinadora, que não somente revelam o pouco entrosamento dos membros com o problema tratado por Mário Pedrosa, como também uma ausência de seriedade e compromisso teórico, com a abordagem proposta pelo candidato. A arguição proferida pelo então reitor da Faculdade, o Professor Pedro Calmon, questiona a ausência de formulação de exemplos próprios na tese e ironiza com uma situação particular, diz o artigo: "Continuando, o Reitor magnífico argumentou que fenômenos da vida comum poderiam ter sido usados pelo Sr. Mário Pedrosa. E contou que quando ele era estudante na Bahia, sua cozinheira jogava um copo d'água na parede para ver que bicho ia dar". (...) Dada a complexidade dos problemas abordados e desenvolvidos por Mário Pedrosa, esta citação parece-nos uma saída tangencial de alguém que não tinha domínio teórico do assunto para tratá-lo com seriedade. Em outro excerto do artigo vemos a mesma situação. Referindo-se à repetição dos mesmos exemplos citados por Paul Guillaume e pelos mestres gestaltistas, o Professor Lucas Meyerhoffer alude ao exemplo da figura de um galo utilizada na tese. (Figura pode ser conferida in: PEDROSA, Mário. Da Natureza Afetiva da Forma na Obra de Arte. In: Forma e Percepção Estética: Textos escolhidos II- Otília Arantes (org.)- São Paulo: EDUSP, 1996. p.145). O Professor Pedro Calmon ironiza o exemplo da figura: "Considerando que o professor Lucas Meyerhoffer fizera 'luminosa arguição', o Reitor disse que o galo referido era do galinheiro de Guillaume. E terminou dizendo que gostaria que o Sr. Pedrosa tivesse exibido galináceos de sua criação particular." À ironia, Pedrosa reponde com o mesmo tom e retoma o esclarecimento de seu esquema teórico seguindo a metodologia de seu trabalho.
} 
O professor Jayme Coelho fez pesadas censuras à tese, embora quase todas elas fossem de natureza marginal ou se desviassem claramente do "X do problema". (...) $\mathrm{O}$ examinador considerou o Sr. Mário Pedrosa um grande crítico de arte, disse que o mesmo era um especialista em "gestalt" ao passo que ele não o era e adiantou que, para entender a tese, era necessário conhecer-se tudo, desde pintura e escultura até ótica. $^{81}$

Diante dos comentários descabidos levantados pelos examinadores, a crítica proferida por Antônio Bento sobre a ocasião da defesa da tese de Mário Pedrosa assinala-se como um aporte sensato e coerente da situação engessada em que se encontrava a classe universitária brasileira. Diz-nos Antônio Bento:

\begin{abstract}
Pois imaginem, se um estrangeiro, entendendo o português, tivesse assistido àquelas declarações (da banca examinadora), que pensaria do nosso ensino universitário? (...) De fato, quem assistiu a defesa da tese feita por Mário Pedrosa, deve ter saído impressionado com a espantosa confissão de ignorância de alguns dos examinadores. Disso se conclui que nossos professores universitários ignoram tudo quanto se refere ao assunto, o qual não entra no programa das nossas escolas superiores. $^{82}$ (BENTO, 1951)
\end{abstract}

O Crítico profere com clareza e pesar, a falta de atualização da classe universitária brasileira e da falta de interesse pelos temas estranhos aos conteúdos programáticos de seus cursos. $^{83} \mathrm{O}$ estranhamento com relação à tese de Mário Pedrosa sinaliza o quanto o crítico estava à frente de seu tempo ao conjugar teorias interdisciplinares e buscar aportes conceituais para além daqueles utilizados e consolidados na teoria crítica brasileira. A mesma oposição e resistência encontrada por sua tese, na década de 1950, encontra quando de seu envolvimento com a estética abstrata, que como uma "nova arte" será vista com desconfiança e preconceito pela mesma classe intelectual que reprovou a tese sobre a gestalt.

Este panorama revela-nos o descompasso das ideias de Mário Pedrosa com relação aos seus pares de época e sobre o interesse e a insistência do crítico de manter-se atualizado sobre as teorias vigentes no universo das artes. Revela-nos, também, as suas preocupações com relação ao alargamento das possibilidades perceptivas no campo das Artes, fugindo a todo engessamento teórico que rejeitasse novas possibilidades de criar e de sentir.

\footnotetext{
${ }^{81}$ Esta citação encontra-se no artigo Mário Pedrosa na Faculdade Nacional de Arquitetura. Tribuna da Imprensa, 14/01/1951.

${ }^{82}$ Bento, Antônio. A "gestalt" e os examinadores. Diário Carioca- Artes, 19/01/1951. Documento pertencente ao Acervo Mário Pedrosa na Fundação Biblioteca Nacional do Rio de Janeiro.

${ }^{83}$ No Brasil, em meados dos anos 1940 em São Paulo, a gestalt estará sendo introduzida no ensino universitário. Na Universidade de São Paulo deu-se com Anita Marcondes Cabral junto ao Departamento de Psicologia. A autora difundiu a teoria da forma, igualmente, em palestras abertas ao público em geral, na Biblioteca Municipal de São Paulo,em 1942, quando era diretor, Sérgio Milliet. Para além, desta iniciativa, pouco se conhecia sobre o assunto no país.
} 
Pedrosa tinha conhecimento fortemente atualizado de autores estudiosos das teorias da gestalt. Sua aproximação a esta teoria atrelada ao estudo da arte coincide no tempo com o desenvolvimento desta empreitada realizada por importantes teóricos do campo da História da Arte, como Arheim, Read, Kepes, entre muitos outros. Sua tese é apresentada, no momento em que se introduz o ensino sistemático destas teorias no país, começando pelos cursos de psicologia e avançando principalmente entre os artistas. Conclui-se então, que Pedrosa mantinha-se atento às perspectivas teóricas e eixos conceituais de seu tempo a fim de contemplar as demandas da arte dos anos 1950.

\subsection{A REPERCUSSÃO INTERNACIONAL DA TESE DE MÁRIO PEDROSA}

É sabido que um trabalho publicado em um único idioma limita seu poder de extensão e alcance. Foi justamente este o problema encontrado para divulgação da tese de Mário Pedrosa. Embora a apresentação da tese date de 1951, a efetiva publicação e divulgação pública ocorrera somente trinta anos depois, no livro "Arte, Forma e Personalidade" em 1979, momento em que o crítico já estava envolvido com outras questões teóricas, e inclusive já se afastado efetivamente da prática crítica, por sua debilitada condição física.

No entanto, mesmo com restrita circulação na época em que fora proferido, o trabalho de Mário Pedrosa despertou a atenção da crítica francesa, na figura de Étienne Souriau, membro do corpo editorial da Revue D'Esthetique, juntamente com Charles Lalo e Raymond Bayer. Este periódico científico francês fundado em 1948 era dedicado a reflexões sobre filosofia da arte e estética. Suas publicações abarcavam artigos dedicados às teorias estéticas, às relações interdisciplinares entre os campos correlatos às expressões artísticas e contavam com resenhas de recentes obras publicadas sobre as artes, música, teatro e literatura, como uma atualização constante do que de novo se produzia neste universo.

Atento às questões e teorias estéticas, Étienne Souriau publica uma crítica elogiosa na edição de julho-dezembro de 1950 de sua Revista, sobre o trabalho apresentado por Mário Pedrosa. Escreve Souriau: «Nous signalons simplement l'excellente qualité scientifique de cette étude, diligente et fort bien documentée,centrée surtout sur le rapport de la psychologie de la forme avec la perception esthétique. ${ }^{84}$ Ao contrário da recepção receosa da crítica

\footnotetext{
${ }^{84}$ SOURIAU, Étienne. Analyses sur PEDROSA, (Mário)- Da Natureza afetiva da Forma na obra de Arte (Rio de Janeiro, 1949, 28/21 cm).In: Revue D’Esthétique, tome trois- fascicules 3 et 4, juillet- décembre 1950. Paris, Presses Universitaires de France. A tradução: "Nós simplesmente observamos a excelente qualidade científica
} 
brasileira, no artigo de Souriau entrevê-se um entrosamento do crítico francês com as questões da psicologia da forma, e ainda que, porventura, não a conhecesse profundamente, reconhecia-lhe a relevância para os estudos artísticos. Seu comentário evidencia uma familiaridade com os estudos e termos gestálticos, pois descreve resumidamente alguns dos termos estéticos desenvolvidos por Mário Pedrosa. Escreve Souriau:

C'est surtout la dernière partie, Forme et Expression, qui permet à l'auteur de préciser ce qui lui semble essentiel à l'œuvre d'art, dont l'existence physique sert de support à des qualités sensibles, à un « objet phénoménal ». L'œuvre d'art se définit par une spécification unique, mais non finalisée utilitairement de sorte que ses qualités sensibles soient liées transitivement et médiatement à cette fin. L'action, en quelque sorte magique, que l'œuvre exerce sur le spectateur, et qui est essentiellement émotive, est exclusivement fonction de ces qualités intrinsèques, et inhère à sa structure formelle. ${ }^{85}$ (SOURIAU, 1950)

O crítico francês tece um comentário curto, porém, em poucas palavras destaca, com simpatia, o trabalho do crítico brasileiro e coloca-se em concordância com suas elaborações teóricas. Em geral, Souriau aponta que os conceitos levantados por Mário Pedrosa tem muito mais relação com a psicologia do que propriamente com a estética. Neste sentido, tese de Pedrosa estaria alocada no domínio da Psicologia e menos na Estética, ou mesmo na Filosofia da arte.

A considerar a breve crítica de Étienne Souriau, nota-se a relevância da problemática levantada por Mário Pedrosa em sua tese. No entanto, ao assinalar as reações da classe universitária brasileira, nota-se que esta não se mostrou atenta às novas teorias que se desenvolviam no cenário internacional. Assinala-se, também, a necessidade que a intelectualidade tinha de conhecê-las, mesmo que sumariamente.

Ainda que, à revelia da opinião de sua época, os estudos desenvolvidos por Mário Pedrosa consolidaram uma Estética da Forma e foram-lhe instrumentos analíticos em seu ofício de crítico. As teses gestáticas fundamentavam sua crítica, que se queria objetiva e que apontava para um alargamento da dimensão perceptiva, onde o espectador se colocava diante

do estudo diligente, e muito bem documentado, o relatório centrou-se principalmente na psicologia da forma com a percepção estética".

${ }^{85}$ Tradução: "Especialmente a última parte, Forma e Expressão, que permite ao autor especificar o que parece ser essencial para a obra de arte, cuja existência física serve de apoio às qualidades sensíveis, a um objeto "fenomenal ". A obra de arte se define por uma especificação única, mas não encerrada utilitariamente, de modo que as suas qualidades sensíveis estão relacionados transitivamente e mediatamente para esta finalidade. A ação, de alguma forma mágica, que a obra de arte exerce sobre o espectador, e que é essencialmente emotivo,e exclusivamente função destas qualidades intrínsecas e inerentes à sua estrutura formal. 
da obra de arte, não para decifrá-la, mas para ouvir e deixar-se interpelar pelo o que a obra de arte seria capaz de transmitir. Com uma citação de Schopenhauer, Mário Pedrosa encerra sua tese: É preciso comportar-se diante de uma obra-prima como diante de um príncipe ; não falar primeiro, mas esperar que ela nos interpele. Do contrário não ouviríamos senão a nós mesmos. (PEDROSA, 1996, p. 177). Era este grau de envolvimento com a obra de arte que Mário Pedrosa queria desenvolver em seus espectadores.

\subsection{PESQUISAS POSTERIORES À TESE DE 1949}

O interesse de Mário Pedrosa pelas teses da gestalt é marcado pelo desenvolvimento da tese Da natureza Afetiva da Forma na Obra de Arte, e por sua inclinação pró-ativa com relação ao estímulo às produções estéticas dos artistas do grupo Frente no círculo intelectual carioca. Pedrosa estimulava os artistas a desenvolverem experimentações estéticas, embasados pelas teses psicologia gestáltica, de modo a suplantarem a percepção figurativa e investirem em ritmos e modulações inovadoras no espaço bidimensional.

No entanto, este interesse pela gestalt, não se circunscreve somente ao período da tese. Em pesquisas realizadas no Acervo Mário Pedrosa na Fundação Biblioteca Nacional no Rio de janeiro, localizou-se um dossiê com manuscritos de Mário Pedrosa, nos quais se encontram anotações descontínuas sobre diversos autores. Tais anotações foram sortidamente redigidas em vários idiomas - inglês, francês, alemão, espanhol, além do português - que podem sinalizar-se como fichamentos e apontamentos sobre leituras e pesquisas realizadas pelo crítico. À primeira página do dossiê encontra-se uma anotação lateral, "este é o problema de minha tese", que porventura, pode estar se referindo à tese de 1949, Da Natureza Afetiva da Forma na Obra de Arte, uma vez que vários dos autores e temas citados nas inscrições manuscritas, referem-se ao tema da percepção artística. Embora a caligrafia de Mário Pedrosa apresente caracteres ilegíveis, alguns autores foram identificados nas citações, tais como: Cassirer, Arheim, Hegel, Merleau-Ponty e Riegl. Nota-se então, que ao lado de suas pesquisas sobre teóricos da gestalt, soma-se uma fortuna crítica de novas formulações teóricas que iam despontando nos campos da filosofia, da estética e da antropologia social. 
Neste dossiê, distingue-se que dois autores são citados com grande frequência, são eles Roger Fry e Anton Ehrenzweig. Sobre as ideias destes autores, Pedrosa atém-se em longas reflexões e comentários. $\mathrm{O}$ dossiê não traz indicações com referência à data de inscrição. No entanto, pela abordagem das obras e autores, talvez fosse possível afirmar que o material tenha sido escrito em meados da década de 1950, pois a obra mais recente, dentre os autores citados, seria a de Anton Ehrenzweig, The psycho-analysis of artistic vision and hearing que fora publicado em 1953 em Londres. Com esta indicação cronológica, pode-se afirmar que Mário Pedrosa segue interessado pelas abordagens gestálticas e por toda sua reverberação teórica, ao longo da década de 1950. Não se trata, portanto, de um crítico "novidadeiro" como se lhe acusaram seus pares outrora, mas relaciona-se a uma busca dos fundamentos conceituais para uma arte que se queria racional e equilibrada.

Anton Ehrenzweig é especialmente citado pela obra The psycho-analysis of artistic vision and hearing publicada em 1953, por dedicar-se ao estudo pormenorizado da percepção artística. Em obra posterior, de 1965, The Psycho-analysis of Artistic Vision: An Introduction to a Theory of Unconscious Perception, o autor estabelece uma conexão entre as teses gestálticas e a psicanálise. Ehrenzweig propõe duas instâncias de percepção, a consciente denominada por ele de percepção de superfície, e a percepção inconsciente, denominada de percepção profunda inarticulada e articula um prolongamento teórico aos esquemas gestálticos, a partir do emprego da dimensão inconsciente e do dissecamento das várias camadas perceptivas. O estudo atento de Mário Pedrosa aos trabalhos de Ehrenzweig, aponta o acompanhamento dos desdobramentos teóricos das teses gestalticas entre as outras ciências. O crítico mantém-se atrelado às pesquisas gestálticas durante todo seu envolvimento com a arte abstrata e durante sua empreitada pela atualização ${ }^{86}$ das artes no ambiente brasileiro. Quando a arte se encaminha para novas experimentações e ganha o ambiente, as teses gestálticas não mais serão suficientes para o embasamento teórico de uma arte que opera com outros patamares perceptivos para além da dimensão visual, uma vez que estas teses estabelecem leis que "engessam" a abrangência perceptiva. Este distanciamento das teses gestálticas se consolida quando da publicação da tese Da Natureza Afetiva da Forma na Obra de Arte na obra Arte, forma e personalidade em 1979, momento em que Mário Pedrosa teria

\footnotetext{
${ }^{86}$ A linguagem artística deveria ser atualizada, para que então o Brasil alcançasse o reconhecimento da crítica mundial com uma linguagem inovadora e atual. Neste contexto Pedrosa foi o grande patrocinador e o primeiro a estimular a arte abstrata no Brasil, além de ser o seu principal teórico, enfrentando a resistência equivocada da crítica nacional.
} 
declarado: "não tenho mais nada a ver com a Gestalt 87 " Para muito críticos e estudiosos da obra estética e política de Mário Pedrosa, esta declaração seria uma negação de todo envolvimento do crítico com esta vertente. No entanto, cumpre-nos assinalar que esta afirmação da crítica parece-nos anacrônica, pois centra-se na relação destas teses com o contexto artístico da década de 1970, que de fato não tinha mais nenhuma fundamentação fincada na formulação da psicologia da forma, uma vez que a arte não era mais forma, mas sim ideia, conceito. A questão não reside na invalidação das formulações gestálticas para pósanos 1950, mas reside na própria problemática da arte das décadas subsequentes que direcionam-se para outras preocupações e abordagens.

Neste sentido, diante de todo o exposto, de todo o interesse e envolvimento de Mário Pedrosa com as teses da gestalt, assinala-se a importância desta teoria como um aporte teórico fundamental para as problemáticas artísticas alocadas na década de 1950. Problemáticas estas, para as quais, o crítico procurou formação, lançando-se em profunda e diligente pesquisa a fim de constituir uma crítica coerente, objetiva e fundada na tradição crítica e filosófica de sua época, à par de todas as novas teorias científicas que inundavam o campo artístico. A gestalt não mais serviu à arte, na medida em que a arte se direcionou a outras experimentações. É neste momento que Pedrosa a pretere por outras correntes que lhe ampare com maior alcance e liberdade criativa para suas inquietações estéticas.

87 Comentário citado por FRAYZE-PEREIRA, J. A. Estética da forma: Mário Pedrosa- crítica de arte, psicologia e psicanálise. Artigo elaborado para o Colóquio Utopias Geométricas e Construtivas- Projeto Arte no Brasil: Textos críticos do século XX, sob a coordenação de Ana Maria de Morais Belluzzo, com apoio da FAPESP, realizado na Faculdade de Arquitetura e Urbanismo- USP, 11 e 12 de junho de 2007, p. 133. 
3 O ENTROSAMENTO COM A OBRA DE ALEXANDER CALDER: APROXIMAÇÕES ENTRE TESES GESTÁLTICAS E CRÍTICA DE ARTE

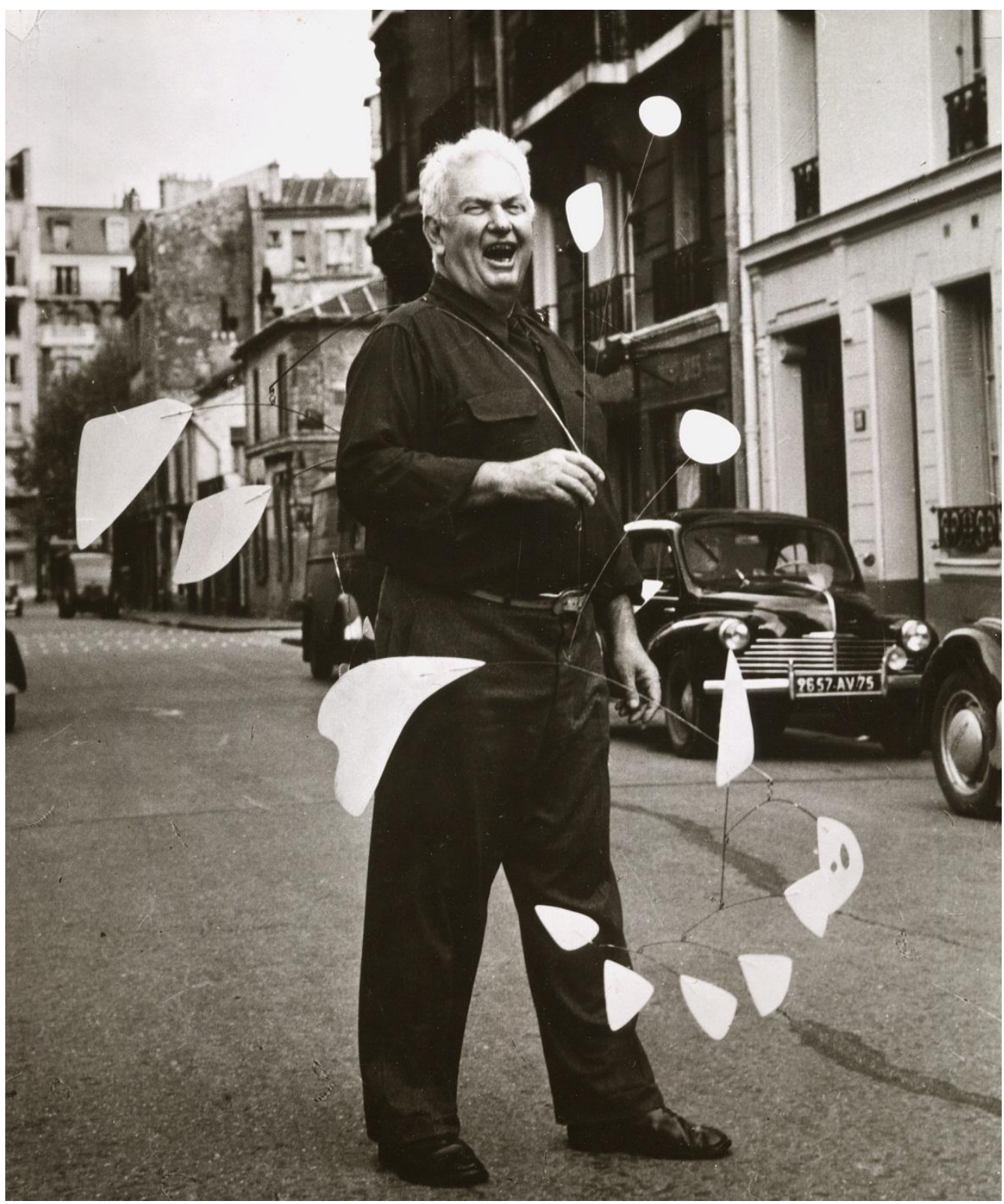

Figura 11: - Calder walking with 21 feuilles blanches,Paris, 1953 Fonte: http://calder.org/archivalphotos/index/110.html 


\subsection{INTERSECÇÃO DA PSICOLOGIA DA FORMA E A CRÍTICA DE ARTE DE MÁRIO PEDROSA}

No âmbito da produção e da fortuna crítica desenvolvida e acumulada pela historiografia da chamada Arte Moderna, a grande questão que se colocava para esta geração era a busca da definição do conceito de forma. Tendo em vista que, as realizações das vanguardas artísticas questionaram e implodiram os cânones artísticos- o esquema compositivo consolidado pela tradição histórica da arte ocidental- assentou-se a necessidade de uma redefinição de paradigmas estéticos. Esta redefinição orientou pesquisas e experimentações estéticas que levaram o campo artístico a debates metalinguísticos.

A produção artística, sobretudo da primeira metade do século XX, logrou questionar e implodir as estruturas pictóricas do paradigma clássico, que até então, dominavam a capacidade perceptiva da recepção estética. Os movimentos artísticos, conhecidos como vanguardas históricas propuseram novas linguagens e técnicas compositivas que desvendaram uma realidade perceptiva, até então, velada pela obsessão da mímese. Cada movimento de vanguarda, em sua medida, remeteu-se a uma questão estética em particular e, cada qual em suas devidas proporções, buscou concatenar a produção artística com a própria crítica da sociedade moderna, no sentido de evidenciar novas formas de olhar e de expressar em uma realidade outra, multifacetada e mutante.

Diante destas mudanças de paradigmas fazia-se necessário o delineamento de premissas e bases teóricas para as novas acepções estéticas. Ao investigar os elementos estruturantes da composição artística, Wassily Kandinsky concluiu que o esquema bidimensional se resumia a ponto, linha e plano, e que articulados compunham um novo conceito compositivo e formal. Neste sentido sua produção artística inaugurou o rompimento com a linguagem figurativa e abriu caminho para novas perspectivas estéticas.

As pesquisas e inquietações das vanguardas históricas questionaram a própria figuração, chegando-se a desenvolver uma linguagem composta de cores, linhas e planos que não apresentavam nenhum signo de alusão ao real. O desenvolvimento desta linguagem que foi designada como arte abstrata, não se baseava somente na desintegração e negação do arcabouço mimético, como também se baseava em uma nova abordagem dos mecanismos perceptivos do homem. Ao se aliar a um vocabulário simbólico da teoria das cores e dos mecanismos visuais de recepção, foi possível desvendar uma imensa potencialidade de produção artística a partir da recombinação programada, ou mesmo intuitiva, de cores, linhas 
e planos. Ao discutir o conceito de abstração, Almerinda Lopes desenvolve a seguinte definição:

\begin{abstract}
O conceito de abstração (...) é empregado em oposição à figuração, representação e imitação. Correntemente, costuma-se adotar a expressão não figuração como sinônimo de abstração, o que não deixa de ser problemático, pois coloca a figura ou representação como parâmetro comparativo (...). [Assim] a abstração é uma linguagem não objetiva, no sentido que rompe com a praxe da representação das coisas do mundo analógico, mas dialeticamente procura o objetivo, pois é articulada segundo o pensamento e a vontade de dar forma, função primordial do processo de criação artística ${ }^{88}$ (LOPES, 2012, p. 15)
\end{abstract}

Nesse contexto é de fundamental importância o estudo das premissas teóricas que acompanharam as pesquisas estéticas desta nova linguagem, com o objetivo de compreender a proposta dos artistas abstratos e dialogar com suas intenções. Dentre estas premissas, a psicologia da forma figurou como uma teoria que deu suporte técnico e científico aos estudos destes artistas.

Ao fundamentar-se nas relações estabelecidas e descritas pela gestalt, o discurso crítico enriquece-se e baliza-se em alicerces científicos, conquistando, assim, habilidades técnicas e teóricas para a composição das análises. Sobre esta relação esclarece-nos, Pallamin:

\begin{abstract}
(...) apoiamo-nos nos princípios que, segundo a gestalt, regem nossa sensibilidade na percepção visual. Princípios estes que não devem ser compreendidos como uma imposição teórica, mas como caracterizando uma exigência psicofisiológica natural (um processo natural da estrutura fisiológica visual) de nosso organismo. Se fazem presentes espontaneamente na percepção e na organização de relações formaisespaciais, eles também podem configurar num útil apoio para sua análise crítica. ${ }^{89}$ (PALLAMIN, 1985,p.20)
\end{abstract}

Neste sentido, ao aliar teoria estética e psicologia da forma, a crítica de arte de Mário Pedrosa, enquadrou-se como uma manifestação pioneira em seu tempo, pois acompanhou estas variações estéticas e empenhou-se por manter-se a par das teorias que estavam pari passu às premissas artísticas. O crítico dedicou-se ao estudo da teoria da forma a fim de compreender as bases da nova estética não figurativa e preparar-se conceitualmente para constituir um discurso analítico sobre ela.

A interação de Pedrosa com o campo das artes e outras vertentes teóricas propiciou um alargamento das possibilidades interpretativas do fenômeno artístico. As incursões pelos estudos gestálticos possibilitaram ao crítico brasileiro, um olhar ampliado e teoricamente

\footnotetext{
${ }^{88}$ LOPES, Almerinda da Silva. Arte Abstrata no Brasil. Belo Horizonte: C/Arte, 2010. P.15, grifo nosso.

${ }^{89}$ PALLAMIN, Vera. Princípios da Gestalt na organização da forma: abordagem bidimensional. São Paulo, 1985. 166f. Dissertação (mestrado) - Faculdade de Arquitetura e Urbanismo, Universidade de São Paulo. p. 20.
} 
instrumentalizado para constituir análises densas do objeto de arte, que extravasavam uma análise superficial e corriqueira. A aproximação à psicologia da forma possibilitou ao crítico, conhecer a fisiologia das estruturas da percepção e da significação que apresentaram-se como um estudo apriorístico, cujo objetivo era delinear o percurso de como o ser humano apreende o objeto artístico. No entanto, as conclusões alcançadas com a psicologia da forma não tinham um fim em si mesmo, mas encaminhavam-se para à problemática artística, especificamente situada na arte abstrata.

A psicologia da forma constitui uma ciência, que se baseia na fisiologia do sistema nervoso, quando procura explicar a relação sujeito-objeto no campo da percepção. De acordo com as teses da Gestalt, o processo de formação de imagens é orientado por manifestações organizacionais inatas do processo perceptivo, onde elementos como equilíbrio, simetria e harmonia visual colaboram para apreensão do objeto que é percebido. Na prática do artista ocorre a concepção e desenvolvimento de objetos capazes de estimular e alargar a capacidade perceptiva do espectador, a partir de uma estrutura formal que considere a interação e a conjugação destas leis. Para Pedrosa a especificidade da arte poderia ser traduzida, como uma resultante entre as qualidades formais do objeto e a intuição do artista e caberia a esta nova arte, a função de renovar a capacidade de percepção em sua essência, com o objetivo de neutralizar a cisão entre inteligência e sensibilidade, uma vez que para a significação da obra colaboravam estas leis da percepção e não somente a interpretação do objeto.

Nesse sentido a crítica de arte se consolida como "uma arqueologia do processo artístico" na intenção de responder às proposições artísticas e tornar evidentes as qualidades formais que serão percebidas por cada espectador. Esta crítica coloca-se, ao mesmo tempo, como informativa e interpretativa, pois deve esclarecer o fenômeno em questão a fim de aproximar o público da obra e fornecer-lhe instrumentos teóricos para ativar a relação entre os dois espectros, e estimular o interesse e o envolvimento do espectador.

Giulio Carlo Argan nos esclarece a função da crítica da seguinte maneira:

A crítica pode ser considerada um prolongamento, ou um tentáculo com o qual a arte tenta agarrar-se à sociedade, qualificando-se como uma atividade não totalmente contrária ou dessemelhante daquelas a que a sociedade dá crédito como produtoras de valores necessários, tais como a ciência, a literatura, a política ${ }^{90}$. (ARGAN, 1998, p. 130).

\footnotetext{
${ }^{90}$ Citado In: ARGAN, Giulio Carlo. Arte e Crítica de Arte. Lisboa: Estampa, 1998, p.130.
} 
Assim sendo, a crítica é um elemento que agrega valor à produção artística, e a utilização de métodos científicos para sua constituição busca a tessitura de uma interpretação que seja objetiva e universal, na medida em que está baseada em uma estrutura perceptiva inerente à fisiologia cerebral e não baseada na interpretação subjetiva e historicamente situada.

Ao longo de seu percurso intelectual, uma das ambições de Mário Pedrosa era delinear a especificidade do conhecimento artístico e sua capacidade de comunicação. Daí a sua abordagem complexa em torno da relação entre subjetividade e objetividade que o encaminharam para o campo de domínio da Gestalt. Esta preocupação com uma abordagem não subjetiva do fenômeno artístico visava rebater as críticas correntes que desqualificavam o campo artístico como domínio não científico, que, portanto, não poderia ser racionalizável.

Os estudos gestálticos relacionados à arte, desenvolvidos por Mário Pedrosa, sobretudo, na tese Da Natureza Afetiva da Forma na Obra de Arte, mostraram que o conhecimento artístico parte de uma dimensão primeiramente perceptiva orientada por leis gerais dadas pelo esquema cerebral. Neste sentido, a percepção primeira do objeto se constitui por um processo fisiológico e, portanto, como inerente a leis gerais, obedece a certa regularidade física e, nestas condições, passa a ser um conhecimento científico.

Assim as informações expressivas e estéticas estariam nas qualidades formais de cada objeto que seria percebido pelo mecanismo humano a partir das atribuições que cada forma traz na organização de seu conjunto pictórico ou espacial. Este processo visual acontece com qualquer objeto que nos chegue à percepção. A grande especificidade do objeto artístico é então, a capacidade extra de comunicar-se com uma segunda dimensão, para além da objetiva. Uma vez apreendida a forma e identificada suas relações, o esquema perceptivo é capaz de ultrapassá-lo e alcançar a dimensão da significação semântica e assimilá-lo como uma experiência subjetiva.

Mas para que o espectador lograsse desenvolver estes níveis de sensibilidades perceptivas, deveria ser "reeducado" para uma nova experiência perceptiva para além da representação mimética clássica. A concepção de Mário Pedrosa sobre a importância e a colaboração do artista no processo perceptivo era bastante nítida, pois o artista deveria "buscar na força expressiva da forma a possibilidade de reeducação da sensibilidade do homem, de modo a fazê-lo transcender a visão tradicional, obrigando-o a enxergar o mundo com outros olhos e, assim, recondicionar-lhe o destino". ${ }^{91}$ (PEDROSA, 1986, p.54) A arte

\footnotetext{
${ }^{91}$ PEDROSA, MÁRIO. Por dentro e por fora das Bienais. In; Mundo, Homem, Arte em crise. AMARAL, Aracy (Org.). São Paulo: Perspectiva, 1986. p.54
} 
abstrata teria então esta função de afastar-se da visão tradicional - a mimética, figurativa- para que o espectador "aprendesse" a olhar e a enxergar outras possibilidades de composições e de sensações que o universo das formas puras seriam capazes de oferecer. Extravazando o universo puramente artístico, a possibilidade de alargamento perceptivo apontava para uma dimensão utópica remanescente do conceito de Revolução Permanente ${ }^{92}$ que acompanhou o crítico por toda a vida. Esta sensibilidade aguçada significaria um ser humano aberto e receptivo a outras ideias, outras vivências e que no limite, fosse receptivo a uma constituição social outra, que fosse diverso daquele modelo desgastado proposto pela sociedade capitalista.

Tendo em vista, estas imbricações entre crítica de arte e teoria da Psicologia da Forma, a partir deste ponto, centraremos a atenção no discurso crítico de Mário Pedrosa, buscando identificar como as teses gestálticas lhe foram úteis para a constituição de seu discurso crítico a respeito da produção artística abstrata.

Assinala-se, porém, que pelo fato de a produção crítica de Pedrosa ser extremamente vasta e diversificada, fez-se necessário, como implicação metodológica, a escolha de um conjunto de textos para serem analisados. Para tanto, elegeu-se um artista em particular, Alexander Calder, por ser, na concepção de Mário Pedrosa, o artista abstrato emblemático, que realizou propostas artísticas que provocaram intenso debate na recepção crítica, como também desafiou as estruturas da recepção estética. Calder foi um dos primeiros artistas abstratos, sobre o qual, Mário Pedrosa escreveu seus ensaios críticos, quando ainda esteve

\footnotetext{
92 Conceito que advém do vocabulário marxista e se relaciona às estratégias políticas para manter os interesses revolucionários da Revolução Socialista, independentes das pressões da oposição burguesa capitalista. Em Trotsky o conceito assume nuances específicos principalmente relacionados à implantação do socialismo fora da Rússia, como oposição ao conceito de Nikolai Bukharin de um socialismo fortalecido dentro da Rússia. Trotsky propunha que a revolução liberal-burguesa, nas condições de um país capitalista atrasado como a Rússia não se deteria na constituição de uma república democrática, mas avançaria para a revolução socialista, num processo sem solução de continuidade - contrariamente ao entendimento evolucionista do marxismo predominante à época, segundo o qual a revolução socialista seria um produto do esgotamento prévio das possibilidades de desenvolvimento capitalista nacional. Após a Revolução de 1917, Trotsky passou a defender também que a revolução socialista era um processo mundial e que a Revolução Russa necessitaria continuar a desenrolar-se numa arena internacional, no âmbito de uma perspectiva internacionalista que contrastava claramente com a política stalinista do "socialismo num só país". Em resposta ao contexto da Revolução Russa, Trotsky formula a teoria da Revolução Permanente que defendia a união de esforços revolucionários em todos os países do globo, defendendo uma Revolução mundial, como medida que manteria não só o socialismo na Rússia, como também se estenderia em parcerias a todos os países e povos e que garantiria a sobrevivência e manutenção do modelo socialista frente aos interesses capitalistas. Segundo Trotsky, as estratégias da Revolução Permanente se estendiam principalmente aos países "atrasados" que ainda não haviam alcançado os níveis mais "desenvolvidos" do capitalismo e que, portanto, segundo a teoria marxista, não estariam previstos nas prescrições da cartilha revolucionária de Marx. A revolução Permanente resultaria então, como um conjunto de estratégias e ajustes políticos a fim de "encurtar" etapas e assegurar medidas com o objetivo único de estabelecer a revolução socialista em qualquer país do globo. Mário Pedrosa como um trotskista convicto manteve a crença no conceito da Revolução Permanente como uma perspectiva no horizonte, e suas realizações estéticas e intenções políticas indicavam que ele a prefigurava como uma possibilidade futura.
} 
exilado nos Estados Unidos, por perseguições políticas da ditadura varguista. No círculo norte americano, Pedrosa acompanhou as atividades dos artistas abstratos e pode avaliar as novas orientações estéticas para os quais a arte moderna se encaminhava. Assim, em 1944 escreveu um conjunto de ensaios sobre as pesquisas estéticas de Calder e o desenvolvimento de sua linguagem dentro da linha construtiva.

A partir do exposto, optou-se pelos textos, Calder, Escultor de Cataventos e Tensão e coesão na obra de Calder - publicados originalmente em Arte, necessidade vital ${ }^{93}$ e coetâneos à execução de sua tese de 1949. Verifica-se assim, no contexto destes textos críticos, como as teses da escola gestálticas foram marcantes e claramente presentes no vocabulário crítico de Mário Pedrosa neste período. Ao assinalar a força espontânea organizadora do aparelho perceptivo, esta teoria era-lhe uma metodologia necessária, na medida em que oferecia subsídios teóricos para compreender a dinâmica interna da obra de arte, e relacioná-la, ao mesmo tempo, à capacidade criativa/intuitiva de seu criador e à recepção sensível/imaginativa de seu espectador. Nestes textos, Pedrosa desenvolve análises sobre a obra do artista norte americano, que claramente demonstram as influências das teses gestálticas como pano de fundo de suas abordagens. A seleção destes textos, em particular, respondem às preocupações estéticas vinculadas à problemática da forma, e em especial, da forma abstrata. Esta problemática norteadora das investigações de Calder será definida e analisada a partir de pressupostos gestálticos, nos quais Pedrosa busca subsídio teórico e metodológico para descrever e enredar uma lógica esclarecedora sobre as obras de arte calderianas que inauguraram uma nova gramática perceptiva.

Mário Pedrosa escreve ainda, outros textos críticos sobre Calder, tais como $A$ máquina, Calder, Léger e outros; Calder e Brasília e Reviravolta em Calder. No entanto, nestes textos a problemática fulcral não passa pela estética da forma e pela constituição de uma linguagem abstrata. Estes textos demonstram uma preocupação mais vinculada ao conteúdo, do que propriamente com a forma. Verifica-se em A máquina, Calder, Léger e outros um grande deslumbramento de Mário Pedrosa com relação à abordagem da máquina na obra de Calder, como uma linguagem tecnológica. Em Calder e Brasília -texto de 1960tem-se um texto prosaico sobre a possibilidade da Cidade de Brasília receber um móbile de Calder. Ainda neste, nota-se a presença do conceito de figura/fundo nas relações que a obra

\footnotetext{
${ }^{93}$ Sobre a publicação destes textos, Otília Arantes esclarece: "Os três artigos constituem uma série de estudos publicados em Arte, Necessidade Vital, pp. 85-142, originalmente redigidos em Nova York, por ocasião da $1^{\text {a }}$ Exposição de Calder nos Estados Unidos, em 1944; os dois primeiros, publicados em dezembro daquele ano no Correio da Manhã, o terceiro, em Política e Letras, Rio de Janeiro, setembro de 1948, ano em que o artista veio expor no Brasil." Citado in: Pedrosa, Mário. Modernidade cá e lá: textos escolhidos IV. ARANTES, Otília (Org.). São Paulo: EDUSP, 2000.p.49.
} 
calderiana poderia cingir com os monumentos de Niemeyer. E no texto Reviravolta em Calder há uma preocupação relacionada ao retorno da figuração e uma vinculação com o samba e a dança como registros de uma imersão etnográfica. Como um texto posterior, de 1975, embora haja uma reminiscência gestáltica em uma passagem, nota-se uma forte influência da fenomenologia embutida na tessitura do texto como um todo.

Diante do exposto assinala-se, deste modo, a razão da escolha dos textos citadosCalder, Escultor de Cataventos e Tensão e coesão na obra de Calder ${ }^{94}$ - por estarem claramente vinculados a uma teoria crítica sobre estética da problemática da forma abstrata.

\subsection{LEITURAS DE CALDER POR PEDROSA: PERCURSO DO ARTISTA RUMO À ABSTRAÇÃO}

Além da amizade que se desenvolveu entre Mário Pedrosa e Alexander Calder, o crítico brasileiro interessou-se pela obra do artista norte americano, por este ter alcançado realizar uma proeza escultórica que parecia impossível. O artista agregou os padrões da linguagem abstrata ao universo da escultura e também inseriu movimento aos padrões que pareciam estar vinculados à produção bidimensional. Tal façanha parecia insolúvel, uma vez que a escultura opera com a matéria tridimensional. A questão que se propunha ao artista abstrato era como escapar da figuração e ainda dar forma a conceitos abstratos sem cair em um niilismo artístico.

Alexander Calder provinha de uma família de artistas- pai escultor e mãe pintora- e desde a infância estivera familiarizado com os procedimentos do ofício, produzindo suas primeiras peças. Na juventude, ao interessar-se pelo mecanismo das máquinas, característica corrente em sua geração, formou-se engenheiro e profissionalizou-se na produção de objetos mecânicos com função industrial, o que de maneira indireta, ainda o mantinha atrelado ao universo da escultura, na medida em que confeccionava peças ou colaborava para sua produção.

A mera produção industrial e a burocracia do tecnicismo não lhe satisfizeram o impulso criativo. O interesse pela dimensão lúdica, perspectiva inerente ao objeto artístico,

\footnotetext{
${ }^{94}$ Para fins práticos, somou-se ao trabalho, as cópias destas duas críticas de Pedrosa. Os textos encontram-se reproduzidos, para fins acadêmicos, nos anexos. O texto Calder, Escultor de Cataventos é o anexo $\mathrm{N}$ e o texto Tensão e coesão na obra de Calder é o anexo $O$.
} 
ainda lhe palpitava como uma vocação. Foi, então, no universo descontraído do circo que Calder reencontrou sua ligação com a arte. Ao frequentar os espetáculos circenses, nos anos em que esteve em Paris, o artista sentiu-se motivado a retomar incursões pelo universo do desenho, a partir, então, de um novo material, o arame. Nesta descoberta intuitiva, Calder relacionou os limites que existem entre o desenho bidimensional e a escultura, pois unificou concomitantemente, as linhas do desenho e o espaço tridimensional, uma vez que o arame possibilita o desenho no espaço. Sobre esta produção com arame, escreve Mário Pedrosa: (...) "as linhas de contorno já tendem mais deliberadamente a organizar o próprio espaço vazio, dando à obra valor plástico estrutural mais acentuado." ${ }^{95}$ (PEDROSA, 2000, p. 54)

Mário Pedrosa deixa entrever nesta descrição alguns preceitos da psicologia da forma ao relacionar a percepção da composição do desenho a partir de linhas construídas no espaço tridimensional. A imagem do desenho se constrói, pela oposição da linha do arame e o vazio, que lhe serve como fundo, sendo este também elemento componente da peça. Uma vez que a fisiologia cerebral percebe as formas de maneira relacional e no caso das peças de Calder, na relação do desenho sinuoso do arame em relação ao seu fundo, ou seja, o vazio. Assim, a obra não é somente o artefato, mas agrega também a composição de seu entorno, que se torna elemento fundamental da peça, como um complemento que lhe dá sustentação visual.

Em suas criações estéticas, o artista americano transitava entre a escultura e a mecânica. E embora, suas criações estivessem no universo da forma tridimensional, Calder sentia-se fortemente atraído pela pintura e pelas realizações estéticas que os pintores modernos desenvolveram. Justamente no campo da pintura, Alexander Calder teve um encontro epifânico que provocou um redirecionamento para sua produção artística. Foi no outono de 1930 que, ao visitar o atelier de Piet Mondrian, Calder impressionou-se com a linguagem abstrata do mestre holandês. Sobre este fato, relatou-nos o artista americano:

\begin{abstract}
Ma première incitation à travailler dans l'abstrait m'est venue lors d'une visite à l'atelier de Mondrian, à automne 1930. [...] je ne sais pas si vous savez comment était alors son atelier- un mur Blanc, assez haut, avec des rectangles de carton peints en jaune, rouge, bleu, noir, et une variété de blancs, punaisés de manière à former une belle et grande composition. J'ai été bien plus touché par ce mur que par ses peintures, bien que je les aime maintenant beaucoup, et je me rappelle avoir dit à Mondrian que ce serait bien si l'on pouvait les faire osciller dans des directions et à des amplitudes différentes (Il n’a pás approuvé) ${ }^{96}$ (PIERRE, 2009,p.32)
\end{abstract}

\footnotetext{
95 PEDROSA, Mário. Calder, escultor de cataventos In: Modernidade Cá e Lá: Textos escolhidos IV. ARANTES, Otília (Org.) São Paulo: EDUSP, 2000. p.54.

${ }^{96}$ PIERRE, Arnauld. Calder- La sculpture en mouvement. Paris: Découvertes Gallimard, 2009. p.32.

A tradução do excerto: "Meu primeiro incentivo ao trabalho abstrato me veio durante uma visita ao atelier de Mondrian no Outono de 1930. [...] Eu não sei se você sabe como, então, seu atelier foi o mural branco, alto o suficiente, com retângulos de papelão pintados de amarelo, vermelho, azul, preto, e uma variedade de cores
} 
Este depoimento de Calder evidencia o impacto que a obra de Mondrian exerceu sobre ele. Impressionou-se pela linguagem austera, pela simplicidade da abordagem das cores primárias e pela composição esquemática e calculada. Impressionou-se, sobretudo, com a força comunicativa que emanava da composição abstrata, principalmente por ser ela construída a partir de linhas e cores, sem estar mediada pela alusão ao real. O exemplo da obra neoplástica de Mondrian impulsionou Calder a uma criação artística que fugia à representação. Este encontro marcou a adesão do americano à linguagem abstrata.

Ao comentar este mesmo fato, que provocou uma reorientação na produção de Calder, Mário Pedrosa nos diz:

Foi neste estado de espírito que recebeu o "choque" de Mondrian. Ele conta, de fato, como, ao contemplar, pela primeira vez, aquela ordem, aquela calma espacial, aquele purismo severo que era o ateliê do artista holandês, reprodução exata de sua própria pintura, um mundo novo se revelou à sua imaginação e lhe abriu a cortina para os horizontes ideais que procurava sem saber: o mundo da pura forma abstrata.(...) Sua obra pode-se então dividir em pré - e pós-Mondrian. ${ }^{97}$ (PEDROSA, 2000, p. 57)

A identificação imediata de Calder com obra de Mondrian resultou do fato de que, ele próprio passara pelo impasse de uma investigação estética que também partia do problema da pesquisa da forma. Ainda que, inicialmente, não houvesse se dado conta de seu problema estético, suas obras buscavam uma forma elementar, ou seja, fosse ela orgânica ou inorgânica, mas que colaborasse para a criação pura, não "contaminada" por padrões ou imposições estéticas de uma escola ou tradição.

A partir deste impacto, diante da solução formal encontrada por Mondrian, Calder se envolve com a estética abstrata, partindo dos padrões neoplasticistas para criar os seus próprios. Desde suas esculturas de arame, Calder já havia chegado à mesma síntese de Kandinsky, de desenvolver o ponto e linha, não mais sobre o plano, mas sobre o espaço, onde o desenho de suas linhas fazia contraste com o vazio do entorno. Neste sentido, Calder se baseou nos mestres abstratos para desenvolver sua própria linguagem e criar os seus critérios.

brancas, fixado de modo a formar uma composição bonita e grande. Eu fui muito mais afetado pelo mural que por suas pinturas, embora eu goste muito delas agora, e eu lembro de ter dito a Mondrian que seria bom se pudéssemos fazê-los oscilar em direções e magnitudes diferente (Ele não aprovou) "

${ }^{97}$ PEDROSA, Mário. Calder, escultor de cataventos In: Modernidade Cá e Lá: Textos escolhidos IV. ARANTES, Otília (Org.) São Paulo: EDUSP, 2000. p.57. 
Como também, se vale da psicologia da forma para embasar suas pesquisas e instrumentalizar-se para a composição abstrata.

No entanto, o desenvolvimento de uma linguagem própria não foi uma tarefa fácil. Pedrosa descreve-nos o problema de Calder:

\footnotetext{
A calma especial, o ritmo e a cor do purismo mondriânico brilhavam aos seus olhos como um tope de montanha inacessível. O artista estava diante do problema, fascinante entre todos, da pesquisa da pura forma- da pura criação. (Ibid, p. 58)
}

Mário Pedrosa identifica no impacto de Calder com a obra de Mondrian, uma descoberta da forma pura, mas não somente de uma pureza contemplativa, mas de uma espécie que ele também desejava encontrar em sua produção, no universo da escultura. Neste sentido, Calder encontrava-se em um impasse, entre uma criação formal desejável e entre uma solução formal que fosse realizável. E na busca desta solução, deste momento em diante, as pesquisas estéticas de Calder, encaminharam-se na direção de descobrir uma maneira "pura" de representar esta forma na escultura, assim como Mondrian a tinha resolvido na pintura.

De esculturas lúdicas e descompromissadas, como os bonecos de arame com temas circenses, Calder insere-se em uma linha de experimentações com formas abstratas. Do encontro com Mondrian em 1930, resulta que já em 1931, Calder inicia sua incursão pelas formas abstratas, nitidamente influenciadas pelo mestre holandês. Seus esquemas compositivos se formavam a partir de figuras geométricas pintadas - com cores primárias, ou principalmente o vermelho, o preto e o branco- que são arranjadas a partir de princípios físicos da mecânica. Calder, então, cria sua série intitulada "volumes, vetores e densidades" que resulta na conjugação das estruturas compositivas do neoplasticismo e pressupostos mecânicos da engenharia, tais como equilíbrio, força, aceleração e esquemas de orbitais. 


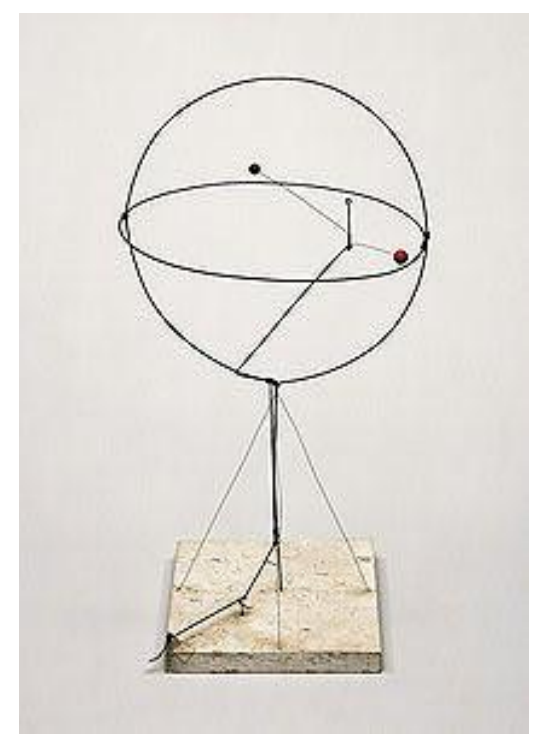

Figura 12: Two Spheres Within a Sphere, 1931 - Arame e madeira pintada 37 1/2" x 32" x 14" Fonte: Calder Foundation, New York ${ }^{98}$

$\mathrm{Na}$ análise de Pedrosa, Calder interessou-se e impactou-se com os esquemas compositivos de Mondrian, pois estes ofereciam uma solução formal ao problema da abordagem da forma abstrata, que o artista americano enfrentava naquele momento. Mesmo impressionado com a organização e o racionalismo das formas e cores de Mondrian, incomodou-se, desde o princípio, com a inércia e os fundamentos estáticos daqueles esquemas. O programa neoplasticista levou a composição abstrata às últimas consequências do purismo formal e do racionalismo construtivo. No entanto, esta plástica não previa o movimento e para tanto, seu esquema conteudístico não dava suporte a esta dimensão transitória que excedia a fixidez e o rigorismo compositivo.

Após esta incursão pelo domínio do purismo formal de Mondrian, Calder encaminha suas investigações artísticas à outra preocupação estética. Interessa-lhe agora a questão da atribuição de movimento às formas abstratas. Neste momento, volta-se então à pesquisa da obra de Juan Miró, pois julgava encontrar neste a liberdade compositiva, e o desprendimento do rigor esquemático para criar e interagir com as formas. Calder já havia conhecido Juan Miró e sua obra, antes do encontro com Mondrian. Mas não se impactara com aquele como se impactou com o último. Este quociente de influências e assimilações está relacionado, aos momentos empíricos e criativos nos quais o artista se encontrava.

Ao considerar as influências de Mondrian e Miró sobre a obra de Calder, assinala-se que as investigações estéticas desenvolvidas pelo artista americano, não estavam nem no artista holandês, nem no catalão, pois os problemas formais e estéticos, que incomodaram a

\footnotetext{
98 Imagem extraída do site: http://calder.org/work/category/standingmobile.html último acesso em 10/06/2012.
} 
estes, partiam de outras preocupações, principalmente vinculadas à elaboração de uma gramática abstrata que traduzisse o desprendimento dos padrões de representação. No entanto, a inquietação de Calder correspondia à busca por uma realização que fundisse a abordagem abstrata e a liberdade de criação e de movimento. Neste sentido, as respostas estavam todas nas realizações estéticas de seu tempo. Mas o que o diferenciou em seu momento foi o problema formal que lhe ocupava as investigações. Assim, conclui-se que as influências dos artistas abstratos lhe foram decisivas, mas foi a sua solução formal individual que o consagrou como um artista de destaque na linguagem abstrata.

Segundo Mário Pedrosa, Calder desenvolve então, uma solução formal que é a síntese, "o resultado da fusão, na sua sensibilidade, do purismo do mestre holandês e da vibração jovial do mestre catalão". 99 Foi nesta fusão de influências que Calder, dialeticamente, desenvolve a sua própria linguagem composta pelas formas puras abstratas que são vitalizadas pelo livre movimento.

Mário Pedrosa desenha estas investigações de Calder da seguinte maneira:

(...) ele toma por um caminho ainda não batido, por assim dizer, fora do campo específico das artes plásticas. Fascina-o o problema da projeção das formas no espaço. A ideia lhe veio de projetar no espaço, de fazer girar aqueles painéis imaculados e estáticos, mas fortemente coloridos do ateliê de Mondrian. O mestre holandês horrorizou-se, naturalmente, com a ideia. Mas esta venceu, pela própria lei mecânica que define o movimento como inseparável do repouso. ${ }^{100}$ (PEDROSA, 2000, p.62)

Ao acercar-se dos princípios utilizados por Mondrian, Calder recai no problema da pesquisa da forma, como também, inevitavelmente, passa pelos princípios gestálticos. À medida que desenvolve suas esculturas abstratas e lhes agrega movimento, a questão da projeção das formas no espaço é resultante dos princípios relacionais da psicologia da forma, pois o esquema visual percebe o conjunto da obra inserida em um contexto de figura e fundo e desta maneira, não há como isolar a obra de arte de seu espaço, é-lhe parte integrante. Além deste princípio, assinala-se que ao conjugar forma abstrata e cores em movimento, o artista encarrega a percepção do espectador para absorvê-la segundo os princípios da organização plástica funcional do espaço.

Sobre as premissas formais da obra de Calder, diz-nos o crítico francês, Arnauld Pierre:

99 PEDROSA, Mário. Calder, escultor de cataventos In: Modernidade Cá e Lá: Textos escolhidos IV. ARANTES, Otília (Org.) São Paulo: EDUSP, 2000. p.62.

${ }^{100}$ Ibidem, p. 60. 
La nécessité d'une sculpture móbile s'impose à Calder en conséquence de sa manière d'appréhender l'espace, comme système de forces et de rapports, comme séjour d'énergies variables, auxquelles il faut donner un support, une expression, à travers ce qu'il nomme "une loi physique de variation". C'est à la découverte de cette loi qu'il se lance aussitôt. ${ }^{101}$ (PIERRE,2009, p. 36)

O conhecimento científico da engenharia ensinara a Calder que as forças naturais do universo são compostas por sistemas de relações entre seus componentes. Assim, quando o engenheiro se concentra na produção artística, terá este conceito como paradigma para sua produção artística. Paradigma este que encontra nas teses gestálticas uma reverberação teórica similar, no tocante à percepção visual e, mais especificamente, ao fenômeno artístico. Não por pouco se interessara por Mondrian, uma vez que estas mesmas premissas já estavam incutidas e embasaram a produção neoplástica daquele.

O encontro de Calder com a gestalt satisfaziam suas premissas. Pois, segundo a escola gestáltica, a percepção não é resultado de estímulos luminosos individuais, onde se distingue o que é objeto e o que é espaço circundante, é, contudo, resultado de uma sensação global, uma apreensão imediata do todo, que se estabelece devido a uma necessidade interna de organização $^{102}$, que é estabelecida por leis fisiológicas naturais. Por conta desta organização perceptiva cerebral, os objetos que percebemos sofrem alterações quando mudamos seu contexto, pois não percebemos unidades visuais isoladas, mas sim a figura na dependência do fundo, uma vez que as são figuras definidas ou delimitadas por seus contornos espaciais.

Tendo em vista as teses desta escola da forma, é possível assinalar que a obra de Alexander Calder é essencialmente gestáltica, pois se baseia nas relações formais que os objetos estabelecem entre si, e entre o espaço circundante. Sendo a percepção da forma um mecanismo comum a todo ser humano, pois parte da fisiologia cerebral e não do acúmulo de conhecimento ou de informações empíricas, a fruição de uma obra de arte como as de Calder é acessível a todo aquele que por ela se interessar e a ela dispensar sua atenção.

Neste sentido, a gestalt coloca-se como uma via democrática de apreensão estética, uma vez que o aparato perceptivo é comum a todos e independe de preparação acadêmica ou

\footnotetext{
101 PIERRE, Arnauld. Calder- La sculpture en mouvement. Paris: Découvertes Gallimard, 2009. p.36. A tradução do excerto: A necessidade de uma escultura móvel se impôs à Calder como resultado da sua maneira de compreensão do espaço, como um sistema de forças e relações, como permanência de energias variáveis, que devem ser dadas um suporte, uma expressão, através do que ele chama de "uma lei física de variação". É à descoberta dessa lei, que ele se lança imediatamente.

${ }^{102}$ Esta definição geral sobre a apreensão gestáltica é uma paráfrase das idéias de Wertheimer desenvolvidas na obra: WERTHEIMER, Max. Principles of perceptual organization. In: BEARDSLEE, David C.; WERTHEIMER, Michel. Readings in Perception. Princeton: Van Nostrand, 1958. Selection 8. p.65.
} 
iniciação estética. A psicologia da forma é uma ciência que descortinou novos horizontes ao campo artístico, ao devolver-lhe o seu caráter orgânico e evidenciar-lhe a pura expressão. Esta ciência também foi capaz de desprender a arte dos conceitos analíticos da tradição histórica da arte e dos padrões compositivos. A partir de seus pressupostos, não se faz necessário ser especialista ou esteta para compreender e para fruir de obras, como as de Calder. Basta interessar-se por seus mecanismos abstratos e com eles interagir.

Ao transcorrer-se por estas ideias estéticas de Mário Pedrosa, nota-se que o interesse pela gestalt e por artistas, que em especial desenvolviam pesquisas estéticas que iam ao encontro desta ciência, respondiam a uma inquietação interna à obra de Pedrosa. Ou seja, corresponder e corroborar aos anseios políticos do crítico e difundir uma sensibilidade universal capaz de despertar e desenvolver no ser humano a sua ligação com o que de pulsante existe na arte.

\subsection{EXERCÍCIO CRÍTICO DE PEDROSA: OS ESTÁBILES E MÓBILES DE CALDER E}

\section{A PERCEPÇÃO DA FORMA}

O texto "Tensão e Coesão ${ }^{103}$ na obra de Calder"104 é especialmente dedicado à análise dos móbiles e dos estábiles do artista. $\mathrm{O}$ autor apresenta suas considerações, em um discurso complexo e laborioso que articula juízos estéticos e poética interpretativa. A estrutura do texto assinala constantemente a psicologia da forma, como a base teórica que ampara suas formulações.

Pedrosa inicia sua crítica, dissertando sobre o esfacelamento do esquematismo mimético da escultura, e como o movimento moderno conduziu os interesses dos artistas a outros temas e preocupações. Interessou-os, principalmente, a força e a velocidade da máquina, como também, um olhar revitalizado para as formas orgânicas e essenciais da natureza. Fosse pelo extremo da técnica, fosse pelo interesse formal do mundo natural, o que

\footnotetext{
${ }^{103} \mathrm{O}$ termo coesão, por definição, refere-se à harmonia e equilíbrio entre as partes de um todo. Assim, o próprio termo escolhido por Mário Pedrosa para intitular sua crítica, já demonstra uma aproximação conceitual com as teses gestálticas e a influência que esta escola exerceu sobre o seu pensamento crítico.

${ }^{104}$ Ensaio escrito em Nova York,em 1944, e publicado originalmente in Arte, necessidade vital. Rio de Janeiro: Casa do Estudante do Brasil,1949, pp.108-129. Em 1948, serviu de base para a conferência "Calder e a música dos ritmos visuais", pronunciadas no Ministério da Educação e Saúde, no Rio de Janeiro, e no Museu de Arte de São Paulo; recolhido in PEDROSA, Mário. Tensão e coesão na obra de Calder. In: Modernidade cá e lá. ARANTES, Otília (org.). São Paulo: EDUSP, 2000. Referências extraídas da obra SARAIVA, Roberta (org.). Calder no Brasil: crônica de uma amizade. São Paulo: Cosac Naify/ Pinacoteca do Estado, 2006.
} 
se assinala, no entanto, é um desinteresse generalizado pela representação do corpo humano e pelas entidades mitológicas do classicismo anacrônico.

Desde a Renascença, se havia cultivado os valores Greco-romanos que consolidaram uma forma de realismo visual, tanto na pintura, quanto na escultura. O movimento moderno, no entanto, propôs uma nova apreensão deste "realismo" e, a partir de diversas pesquisas estéticas desenvolvidas pelos artistas, descobriram premissas diferentes de representar e interpretar a realidade, que correspondiam ao que Pedrosa denominou de realismo "mental". Este novo olhar para a realidade remetia-se ao praticado pelos povos primitivos ou pelas culturas não-ocidentais, e implicava um conjunto de técnicas que assinalavam à articulação de uma nova sensibilidade.

A Renascença foi o período em que o desenho atingiu a plenitude do realismo, que através de rígidos esquemas formais padronizou um sistema de representação na arte do ocidente. No entanto, as inquietações e as produções das vanguardas históricas do fim do século XIX e do início do XX, encaminharam esforços para a desintegração paulatina da verossimilhança. Assinala-nos Pedrosa que "a curva histórica, desde então até hoje, foi no sentido de uma libertação crescente do desenho, que ganha em ritmos livres, e flexibilidade, o que perde em fixidez formalística."

As concessões que as premissas modernas fizeram à libertação do desenho resultaram na perda da fixidez temática e, sobretudo, formal. Porém, ganhou-se em conhecimento e domínio de novas linguagens estéticas e no enriquecimento de novas possibilidades de compor, de traduzir o real em linguagem plástica, o que em profundidade revolucionou as formas de pensar, de ver e de sentir.

Nesta dissolução desejada e intencional do padrão clássico, Pedrosa aponta uma categoria em especial, a simetria. Ao abrir mão deste esquema estrutural, a arte moderna ocidental se aproximou da premissa da arte chinesa da ideia do "equilíbrio assimétrico", uma vez que não se destaca o equilíbrio de um elemento em particular, mas valoriza-se o equilíbrio do conjunto compositivo.

Alexander Calder expressa familiaridade com este princípio chinês, ao identificar nos elementos naturais, como árvores e vegetais, inspiração estética para a criação formal. Além deste, Calder também assimila o princípio da assimetria intencional. Esta concepção de organização formal somente pode ser possível, quando se adota um sistema compositivo baseado em planos e linhas, e não mais no volume maciço do conjunto. Neste sentido, Calder

\footnotetext{
105 PEDROSA, Mário. Tensão e coesão na obra de Calder. In: Modernidade cá e lá. ARANTES, Otília (org.). São Paulo: EDUSP, 2000.p. 68.
} 
extrai da natureza as suas linhas de força para serem insinuados através de seus esquemas. À medida que o artista se afasta do modelo compositivo clássico, descobre uma linguagem elementar para a abordagem destas linhas de força essenciais da natureza. Vale-se então, de linhas, planos e do espaço que se conjugam em composições sóbrias, limpas de excessos e organizadas por padrões físicos que atribuem ordem e racionalidade do conjunto.

A obra de Calder para além de uma pura geometria no espaço é pioneira em um estilo de abstração, que se compõe de uma plástica estruturada por "esquemas vetoriais" que dão coesão ao conjunto de linhas e planos. Esta estrutura artística inicialmente caracteriza-se por um "frio rigor científico", pois Calder ainda mantinha a influência austera não só da abstração de Mondrian, mas também das premissas construtivistas e não- figurativas do grupo Abstração- Criação, a o qual Calder se filiara em 1931. Ao agregar estas perspectivas a sua obra, neste mesmo ano, o artista realiza uma exposição com obras que faziam referência às leis físicas e ao mundo natural.

As primeiras composições abstratas de Calder foram denominadas pelo artista francês Jean Arp de estábiles, pois agregavam formas abstratas coloridas com o espaço circundante, mas ainda seguiam estáveis e sem movimento. Muito embora, os estábiles de Calder não possam mover-se, são dotados de uma "relação ideal do objeto no universo", pois como figuras abstratas não existem objetivamente, mas a partir do momento que passaram a ser um objeto criado, agregam relações com o mundo objetivo, ou buscam no espaço, o seu lugar próprio como coisa existente. Calder as definiu como "um sentido de relação cósmica" uma vez que inauguram no universo uma nova forma que não está submetida a nenhuma outra que já exista, mas, no entanto, assentam-se como nova criação. 


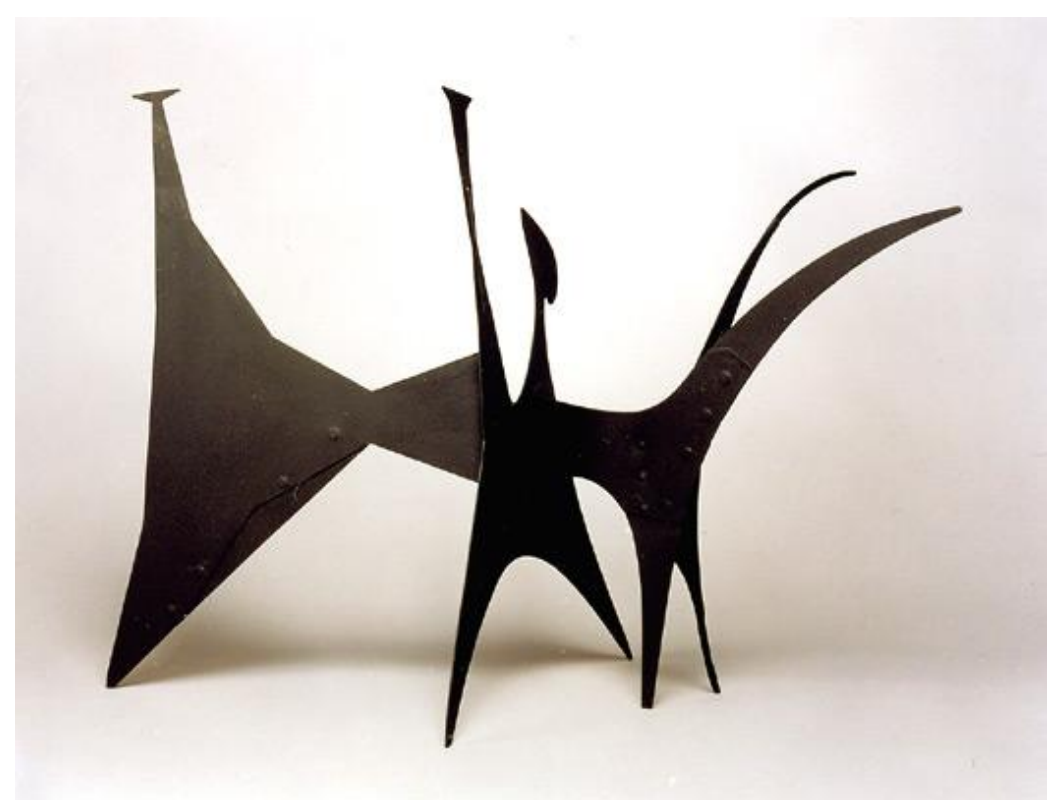

Figura 13: Besta Negra [maquete], 1939 - Folha de metal e pintura 21 "x 28" x 17 " Fonte: Calder Foundation, New York ${ }^{106}$

Como um criador "cósmico" Calder extrai imagens e formas de onde parece impensável surgirem. Neste plano cósmico, como nos descreve Pedrosa, Calder não só cria elementos no universo, como também os completa com as relações espaciais. O que de fato vai dar a ossatura da obra são os padrões gestálticos de equilíbrio, como a harmonia da composição plástica em relação ao seu fundo, pois estando a obra alocada em um espaço, se valerá deste para completar-lhe com um alicerce estrutural de seu enquadramento. Nesta dimensão, as apreensões gestálticas não são somente um método de análise do fenômeno artístico, mas são parte integrante da obra, que agrega a visão e apreensão do todo conjuntural.

A obra de Calder encarna a junção da pesquisa abstrata com a técnica da mecânica, o que resultou em uma especificidade estilística que agrega liberdade compositiva e densidade construtiva. Mário Pedrosa descreve-nos esta obra como o encontro entre o domínio da técnica e superação da rigidez das leis físicas. Diz-nos o crítico, "graças a tal fluidez, seus objetos ganham em latitude plástica, criando relações mais pesadas de universalidade, libertos de quaisquer limitações contingentes ou unilaterais." ${ }^{107}$ (PEDROSA, 2000,p. 70)

Além de dominar a técnica dos estábiles, Calder direciona suas pesquisas para a agregação do movimento ao seu universo compositivo. Suas novas obras são então denominadas por Marcel Duchamp de Móbiles por serem dotadas da capacidade de moverem-

\footnotetext{
106 Imagem disponível em http://calder.org/work/period/1937-1945/10.html, último acesso em 30 de junho de 2012.

${ }^{107}$ PEDROSA, Mário. Tensão e coesão na obra de Calder. In: Modernidade cá e lá. ARANTES, Otília (org.). São Paulo: EDUSP, 2000. p. 70.
} 
se no espaço. Com o domínio da manipulação de mais este elemento físico, Calder conquista uma infinidade de possibilidades de relações com a sua obra artística. Caracteriza-nos Pedrosa:

\footnotetext{
Para ele,(...), não passam de "formas plásticas em movimento". Mas este não é um simples movimento de translação ou rotação, e sim de diferentes tipos, velocidades e amplitudes, que, reunidos, combinados ou compostos, dão uma resultante total. E ele explica: assim como se pode compor cores, ou formas, assim também se pode compor móbiles... (Ibid,p. 70)
}

Marcel Duchamp já propusera a idéia do móbile anteriormente, ao explorar o conceito de formas abstratas no espaço, porém sua obra não trazia a mesma proposta estética que Calder agregou a estas formas. A questão abordada nestes móbiles calderianos extravaza a pura confecção de um artefato artístico, mas engloba a capacidade perceptiva do espectador, sendo ele responsável por observar e estabelecer as relações espaciais e formais do conteúdo abstrato e técnico da obra, segundo seu arcabouço cognitivo e seu envolvimento gestáltico.

Estas infinidades de relações e combinações compositivas, que os móbiles em movimento são capazes de oferecer estão intrinsecamente relacionadas a conteúdos físicos e mecânicos, pois uma vez acionados ao movimento, somente voltam ao estado de repouso, mediante a condição de equilíbrio de seus pesos, contrapesos e medidas, ainda que, conquistado à revelia do princípio da simetria clássica. Assim, a obra de Calder somente retorna ao estado de repouso, quando conjuga equilíbrio dos pesos dos corpos físicos e equilíbrio assimétrico de seus elementos.

Para a realização de sua obra, Calder não somente infringe as regras clássicas de composição, como subverte os princípios gestálticos de organização da forma, e também altera a própria dinâmica das forças físicas. Toda esta sucessão de desvios infratores colabora para a performance perceptiva e plástica que o artista constrói com seus imprevisíveis movimentos.

Ao serem movimentados, os móbiles vão desequilibrando-se formalmente, mas buscam um equilíbrio espacial a partir das relações que estabelecem com seu entorno físico, com seu fundo, as nuanças de cores, e os espectros de luzes e sombras. Por mais díspares que sejam suas formas, o esquema cerebral do receptor sempre procurará organizá-las segundo o princípio da Boa Forma- ou da pregnância- no sentido de esclarecer a imagem vista, ou a forma do conjunto. Por esta razão, à medida que o móbile se movimenta e provoca alterações da disposição do conjunto, mais e mais formas de múltiplas significações vão se formando e se agregando ao espectro perceptivo do espectador. 
Em cada movimento, o aparato mental do observador procura automaticamente articular um sentido formal à imagem solta no espaço. Cada elemento pode ser identificado com formulações afins, mas que, no entanto, remete-se à constituição do sentido do todo. Em cada efêmero movimento, o móbile pode ser identificado pelo cérebro como um pássaro, uma flor, um peixe, uma nuvem, um cometa, ou quaisquer outros, desde que algum elemento comum a estas figuras seja identificado no objeto amorfo. Tal profusão de imagens e conjuntos é que provoca a fascinação de quem olha. Sobre a relação obra- espectador, diz-nos Mário Pedrosa em seu texto:

Com um sopro podemos tanger um móbile, cujos braços ou pétalas ou bolas se agitam e desenham no ar uma sucessão de formas imprevistas que se vão convertendo, umas após outras, em vertigem caleidoscópica, (...). O gesto, embora apenas estado mental, precede e não se aparta da obra de criação realizada. Seu objeto adquire uma ressonância de instrumento - que dança, ou vibra, ao ser tocado. (Ibid, p. 71)

Neste sentido, faz parte da obra, além dos planos, linhas e cores, o gesto do espectador que aciona o movimento. Este é, pois, a energia motriz, o combustível que faz o conjunto da obra funcionar. Este gesto, como estado latente é pensado como elemento da obra, não é uma contingência, mas está previsto como componente adjunto, para que a obra se realize de fato. Juntos, então, como peças de uma mesma engrenagem, darão vida "à coreografia abstrata".

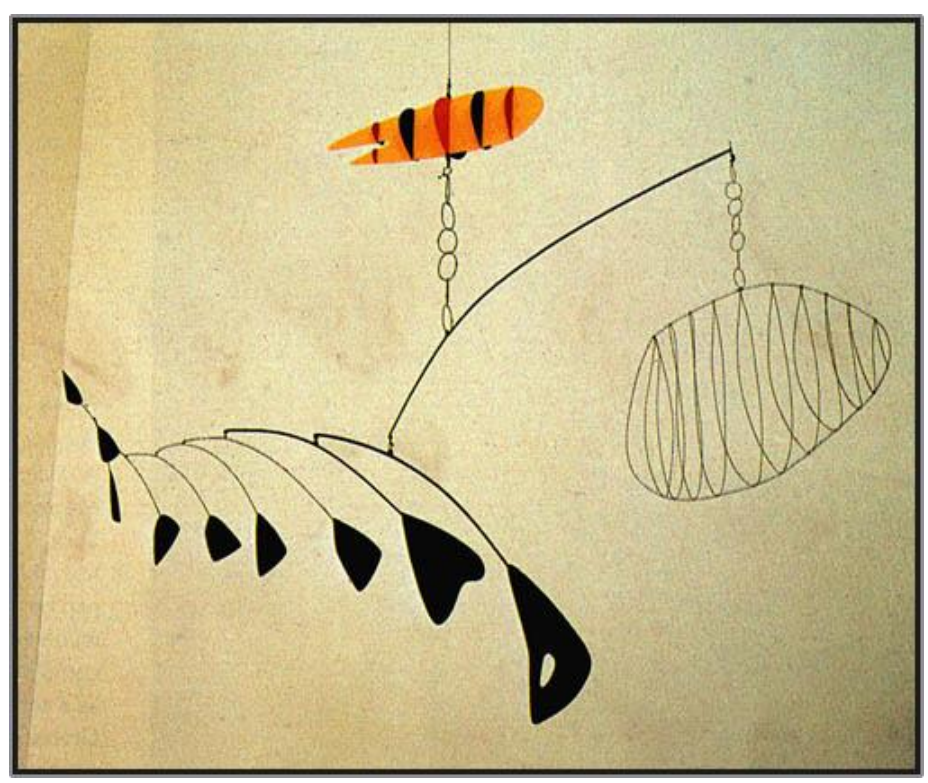

Figura 14: Alexander Calder, Armadilha de lagosta e rabo de peixe, 1939. MoMA- Nova York. ${ }^{108}$

\footnotetext{
${ }^{108}$ Peça composta a partir de arame de aço pintado e chapa de alumínio, com dimensões de 8 '6 "(260 cm) x 9' 6" (290 cm) de diâmetro. Encomendado pelo Comitê Consultivo para a escadaria principal do Museu de arte moderna de Nova York. (C) 2012 Calder Foundation, New York / Artists Rights Society (ARS), New York. Fonte http://www.moma.org/collection/object.php?object_id=81621 último acesso em 30 de junho de 2012.
} 
Fonte: http://www.moma.org/collection/object.php?object id=81621

Neste sentido, Calder subverte mais uma dimensão de sua obra, a do espectador. Como a própria palavra assinala, o espectador é aquele que assiste, observa, que vê sem participar e que é receptáculo passivo do que se lhe vier aos sentidos. A obra de Calder, no entanto, não se contempla com este tipo de espectador, é-lhe necessário outra categoria de público, que abandone sua condição de passividade e se torne um interlocutor da obra de arte. O público desejado é este que assume o seu lugar no diálogo com a obra e doa-lhe o gesto do movimento, como a força motriz que mantém a máquina em funcionamento. Nesta redefinição de papéis, o público é a energia vital do fenômeno da obra de arte. Sem ela, a obra é somente mais um artefato.

Os móbiles de Calder podem ser assimilados como detentores de duas dimensões distintas. A primeira é a sua condição matérica, composta por seus elementos reais, tais como, madeira, tintas, chapas de ferro, aço ou arame. Poderíamos caracterizar esta dimensão como imanente, pois é o objeto real, permanente. A segunda dimensão da obra está relacionada a um conjunto de circunstâncias que envolvem o entorno, o gesto do espectador de tocar o objeto e o efêmero momento do movimento que se caracteriza como se fosse a alma da obra de arte, como a anima ${ }^{109}$ divina que confere vida à matéria inerte. Neste sentido, pode-se aferir que a atuação do espectador é semelhante à ação sobrenatural, ou divina, que compartilha com a matéria a sua vida, e lhe incute uma perspectiva transcendente, na medida em que excede a experiência material.

Mário Pedrosa se reporta a esta ideia quando se refere, de maneira análoga, à participação do expectador como o portador do impulso inicial do gesto cinético como "o impulso aristotélico do primeiro motor, o ponto de onde se inicia e toma vida todo objeto no mundo". ${ }^{110}$ Sendo assim, Calder é o criador do objeto e o idealizador do gesto desejável do espectador que atribuirá movimento e vibração à sua obra. Assim, o gesto, embora apenas estado mental, precede e não se aparta da obra de criação realizada ${ }^{111}$, o que segundo a apreensão do crítico, quer dizer que o gesto é estado mental na concepção do criador, mas é condição sine qua non para a plenitude da criatura, ou neste caso, da obra de arte.

\footnotetext{
${ }^{109}$ A palavra anima do latim significa alma, a pulsação que transforma a matéria inerte em ser vivo. Caracterizase como a vibração e o vigor daquilo que é inerente aos instituídos de vida. É também relacionado à psique e ao universo interior. Fonte: Dicionário Aulete digital (Parafraseado) http://aulete.uol.com.br/site.php?mdl=aulete digital\&op=loadVerbete\&pesquisa=1\&palavra=alma\&x=4\&y=14ú

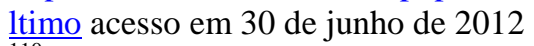

${ }^{110}$ PEDROSA, Mário. Tensão e coesão na obra de Calder. In: Modernidade cá e lá. ARANTES, Otília (org.). São Paulo: EDUSP, 2000. p. 71.

111 Ibidem.
} 
Outra analogia desenvolvida por Pedrosa para descrever a lógica de funcionamento dos móbiles é a ideia de um instrumento musical que é manipulado pelo espectador e emite ressonâncias de movimento de acordo com o impulso e a técnica daquele que o opera. Para Pedrosa a relação das obras de Calder vai mais além. O crítico alia não somente o gesto de movimento, mas também sua intensidade que determina o ritmo do "baile" dos objetos. Ainda nestes termos, assim como a definição de música se relaciona à combinação de sons e pausas (silêncios), a partir de uma organização estabelecida ao longo do tempo, os ritmos de Calder estariam demarcados pelos ritmos combinados entre movimentos e repousos ao longo de um tempo, tempo este que é determinado pelo espectador ou pela energia de sua ação.

Nesta analogia com o universo da composição musical, também é possível destacar, na concepção do crítico, a ideia permanente da psicologia da forma como uma estrutura de análise que permeia as considerações e as implicações conceituais de sua crítica. Pois assim como a música é feita de relações temporais, a obra de Calder compõe-se de relações espaciais, ou seja, em ambos os fenômenos artísticos a obra se executa nas relações que estabelece com seus elementos estruturantes e não em sua condição matérica.

Nota-se nas considerações de Mário Pedrosa, a convicção de que a experiência estética na obra de Calder é baseada e fundamentada em um sistema de relações entre partes e todos, figuras e fundos- em princípios de semelhança, pregnância, fechamento, equilíbrio. Sem o conhecimento das teses gestálticas, não se alcança proceder à compreensão e vivência dos objetos de Calder em sua totalidade, e muito menos atingir, em termos de análise, a interpretação e síntese da organização visual e conceitual de suas formas.

Ao inserir a instância do movimento em suas obras, Calder cria possibilidades infinitas de relações espaciais. Estas possibilidades, no entanto, somente são possíveis devido a um contraponto de forças físicas, a dinâmica de equilíbrio e desequilíbrio. O mecanismo do objeto artístico de Calder somente é acionado, quando esta dinâmica é alterada. Assim, todo o sistema de equilíbrio é criado a partir de um único ponto fixo que regula toda a tensão, drama e diversificação do conjunto. Aliás, toda a dramatização do conjunto se forma a partir da expectativa do espectador, de como o único ponto fixo do móbile dará conta de atribuir coordenação e equilíbrio às partes componentes que foram intencionalmente desarticuladas por uma energia motriz. O reajuste do conjunto se constrói na busca do equilíbrio e na distensão das forças, que são dados a partir da diminuição gradativa de perda de movimento até finalmente reencontrar seu equilíbrio no estado de repouso. O espetáculo da obra de Calder se realiza durante o desenvolvimento desta dinâmica e é a ação do conjunto de tensões 
entre movimento/ repouso e equilíbrio/desequilíbrio que desperta a atenção e interesse do espectador.

Neste sentido, a verdadeira obra de arte de Calder não está no objeto artístico em si, mas reside na dialética de forças físicas que atuam sobre o objeto, e do qual o objeto é refém. Sobre ele atuam duas forças distintas e opostas: uma força que é a energia motriz da obra e aciona o movimento- a qual pode ser dada pela energia humana, pela energia eólica ou pela energia elétrica- que retira o conjunto da condição de repouso e o desestabiliza e o impele ao movimento. Esta força de ação que provoca o desconcerto das peças será, então, controlada e contida pela força de reação, que regula o conjunto ao estado de equilíbrio. Esta segunda é uma força de resposta, e corresponde à tensão exercida no ponto fixo que suporta e sustém todo o conjunto. Esta tensão media a força aplicada redistribuindo-a a fim de que o conjunto se equilibre e volte ao estado de repouso.

É a ação da tensão, que provoca o desequilíbrio das forças e retira o objeto da condição de repouso, possibilitando que o sistema seja reativado. Desta forma, o sistema funciona como um circuito elétrico fechado, na medida em que o movimento traçado pelo móbile não é arbitrário, ou despropositado, mas é constantemente determinado pelo equilíbrio que deve ser mantido. Pode-se afirmar, então, que a obra de Calder é a performance resultante da ação e reação de forças sobre o objeto. A obra de arte, como acontecimento é a síntese que se constrói a partir da dialética do equilíbrio e do desequilíbrio.

Pedrosa assinala que nesta dinâmica, a obra reúne em si elementos estruturais da escultura e da música, uma vez que coaduna a percepção espacial, da escultura em seu meio, e a percepção temporal, uma vez que a as imagens se modificam, à medida que o tempo transcorre. Neste sentido, as obras de Calder incorporam o elemento tempo como uma dimensão nova, que assimila não somente o movimento e a variação das formas no espaço, mas também o ritmo de deslocamentos que expressam a vida do conjunto.

Além de assinalar a dimensão espacial e temporal, Mário Pedrosa propõe ainda a influência do acaso no acontecimento da obra de Calder. Trata-se da ingerência do imprevisível, e da indefinição. Neste sentido, as formas que se vão definindo no móbile, entregues ao movimento são despropositadas e aleatórias. Este acaso somente pode ser delimitado, descrito e por fim definido, quando acontece, ou se realiza. Ainda assim, não é percebido como acaso, pois a percepção cerebral tende a circunscrevê-lo em algum conceito prescrito. $\mathrm{O}$ acaso na obra de arte é um fenômeno visual e como tal, deve ser codificado por uma análise perceptiva, antes ser comunicado através da linguagem verbal e cognitiva. 
As experiências das formas do acaso nos móbiles de Calder, antes de serem identificadas com um nome ou conceito, são processadas pela fisiologia gestáltica do esquema cerebral. A virtualidade das formas casuais ou do que está solto no espaço, sem nenhum vínculo intencional, será identificada pela capacidade visual do espectador, que irá detê-la e processá-la em informação. Este processo não é intelectual, muito menos associativo, mas é parte das propriedades intrínsecas das formas. Diz-nos Pedrosa em sua tese Da Natureza Afetiva da Forma na Obra de Arte: "A interpretação gestaltiana explica o fenômeno pela própria forma. A boa forma tende irresistivelmente a completar-se". ${ }^{112}$ Pelos princípios da gestalt, Pedrosa explica como a percepção apreende as formas livres dos móbiles calderianos, fundamentadas, não na livre associação, mas atribui-lhe um sentido por suas próprias leis internas de organização, formadas a partir de um todo figural dado por suas relações de proximidade, de boa forma, de simetria, de fechamento e de sentido em relação ao seu fundo. É o conjunto destas propriedades que organizam e significam a forma percebida.

Mário Pedrosa vale-se ainda de outra implicação gestáltica na análise da obra de Calder, quando se refere ao papel criativo do espectador na construção da obra, diz o crítico, "não é, porém, a mera percepção visual de um objeto em repouso ou em movimento que o inspira; é a imaginação plástica." 113 A identificação de formas reconhecidas durante os movimentos rítmicos dos móbiles, tais como animais ou objetos que se formam no espaço, é resultado instantâneo da ação das forças mentais de organização sobre o que se está sendo visto. Assim, como o caos é-nos intolerável, a fisiologia perceptiva cerebral ordena as formas a fim de que o cérebro as incorpore de modo lógico e definido. A organização da completude visual de formas desarranjadas é atribuída pela imaginação.

Umas das conclusões de Pedrosa em relação à imaginação plástica é que, “o próprio ato de perceber já é um ato de criação" ${ }^{\text {, } 114}$ ou seja, o fato de tal fenômeno ter sido captado e percebido pela visão, traz consigo um conjunto de relações formais e espaciais que foram organizadas pela fisiologia cerebral, e que de certa maneira, envolvem um esforço criativo do cérebro para completar a informação, de modo a ser assimilada pela percepção da maneira mais clara e definida possível. A partir deste princípio, as obras de Calder requerem não somente a atenção visual e motora de seu espectador, na medida em que ele aciona o conjunto

\footnotetext{
${ }^{112}$ PEDROSA, Mário. Da Natureza Afetiva da Forma na Obra de Arte. In: Forma e Percepção Estética: Textos escolhidos II- Otília Arantes (org.)- São Paulo: EDUSP, 1996. P.146.

${ }^{113}$ PEDROSA, Mário. Tensão e coesão na obra de Calder. In: Modernidade cá e lá. ARANTES, Otília (org.). São Paulo: EDUSP, 2000. p. 72.

${ }^{114}$ PEDROSA, Mário. Da Natureza Afetiva da Forma na Obra de Arte. In: Forma e Percepção Estética: Textos escolhidos II- Otília Arantes (org.)- São Paulo: EDUSP, 1996. P.177.
} 
ao movimento, mas requer também um diálogo com a imaginação do espectador que é cocriadora da obra juntamente com o artista.

Neste sentido o espectador é participante da obra em três dimensões: Como força motriz que aciona o movimento do conjunto; Como espectador que observa o baile rítmico da obra, gerado pela tensão das forças que colaboram para o equilíbrio do conjunto, ou que reatam o estado de repouso; e Com sua participação imaginativa, que atua de maneira criativa a ser co-autora da obra, na medida em que imagina, delineia e cria imagens e sentidos que completam os constructos formais dos planos e linhas em movimento. Nesta dimensão criativa, o espectador assume para si o caráter enigmático da obra, uma vez que é a imaginação que lhe completa e lhe decifra. Como esta criação de imagens é dada pela ação das forças mentais de organização da forma, a resposta demonstra-se intuitiva e não necessariamente, lógica, uma vez que as relações de sentido são perceptivamente completadas pela imaginação plástica e não pelo arcabouço intelectivo armazenado pela memória.

Além de estábiles e móbiles, Mário Pedrosa ainda situa, dentro da produção calderiana, a dinâmica repetitiva dos painéis motorizados. O crítico assinala que, o movimento resultante das relações entre os objetos é repetitivo e ao mesmo tempo inovador, pois se repete a mecânica do movimento, mas cria-se uma relação de drama entre as formas geométricas e as forças invisíveis da natureza. Sobre esta consideração, podemos referir-nos à outra citação de Mário Pedrosa em sua tese de 1949. Escreveu o crítico:

Todo sistema gerado é feito de um choque de forças; sua unidade é sempre dinâmica. Não há forma sem drama. A tensão espacial é a alma de tudo o que vemos. A qualidade viva de uma imagem, disse Kepes, é gerada pela tensão entre as forças espaciais. Estas, porém, não têm poderes de se manifestar isoladas, por si mesmas. Sua presença só se sente diante da resistência que outra lhe faz. (PEDROSA, 1996,p. 131)

Por mais que a obra nos pareça monótona e inerte, ainda assim, ela traz em seu bojo uma dinâmica que se orienta entre os movimentos que podemos acompanhar. À relação compositiva entre molas e formas geométricas soma-se a propulsão gerada pelas forças físicas invisíveis que atuam sobre o conjunto do objeto. Neste sentido, o drama da obra reside nesta relação invisível, mas que, no entanto, é percebido pelo cérebro, e assimilado como algo que pode ser modificado a qualquer momento.

Os painéis motorizados de Calder operam com outra concepção mecânica, distinta daquela presente nos móbiles, uma vez que não há previsão de inovação e surpresa. $\mathrm{O}$ conjunto impressiona pela rígida repetição física, que provoca no espectador uma expectativa 
epifânica de que em algum momento a repetição do conjunto poderá ser rompida e, então, alterar a ordem do conjunto. Assim, a obra se constrói não no desequilíbrio programado e retomado, mas no desequilíbrio desejado e aguardado. A dinâmica das forças físicas cala a expectativa de revelação inesperada e retomam o equilíbrio comum.

A obra de Calder não pretende ser efêmera e momentânea. Não está no ínfimo momento em que a mente capta a percepção de um objeto. A sua concepção artística reside na capacidade perpétua e ilimitada de arranjos formais que se reajustam virtualmente durante cada movimento. Além das descrições sobre o movimento, Mário Pedrosa faz uma menção especial ao repouso como uma condição que guarda consigo, todas as possibilidades de movimentos e formas. Neste sentido, pode-se aferir que o movimento é a circunstância teleológica do repouso, uma vez que a finalidade da lógica calderiana é a conquista do movimento em suas obras.

Sendo assim, conclui-se que é em seus móbiles que Calder encontra a superação de suas inquietações plásticas e pôde então levar o mundo das formas aos ritmos livres e fortuitos. A ausência do volume maciço na escultura possibilitou às peças de Calder, entregarem-se aos contornos do espaço e assim estarem livre aos movimentos que lhe forem impelidos. Este sistema de relações entre o objeto, força de movimento e espaço possibilitam a geração múltipla de formas variadas que serão criadas e semantizadas pela imaginação. Este esquema compositivo é potencialmente mais discursivo, e atribuído de significações iminentes, que a escultura maciça clássica jamais fora capaz de oferecer. 


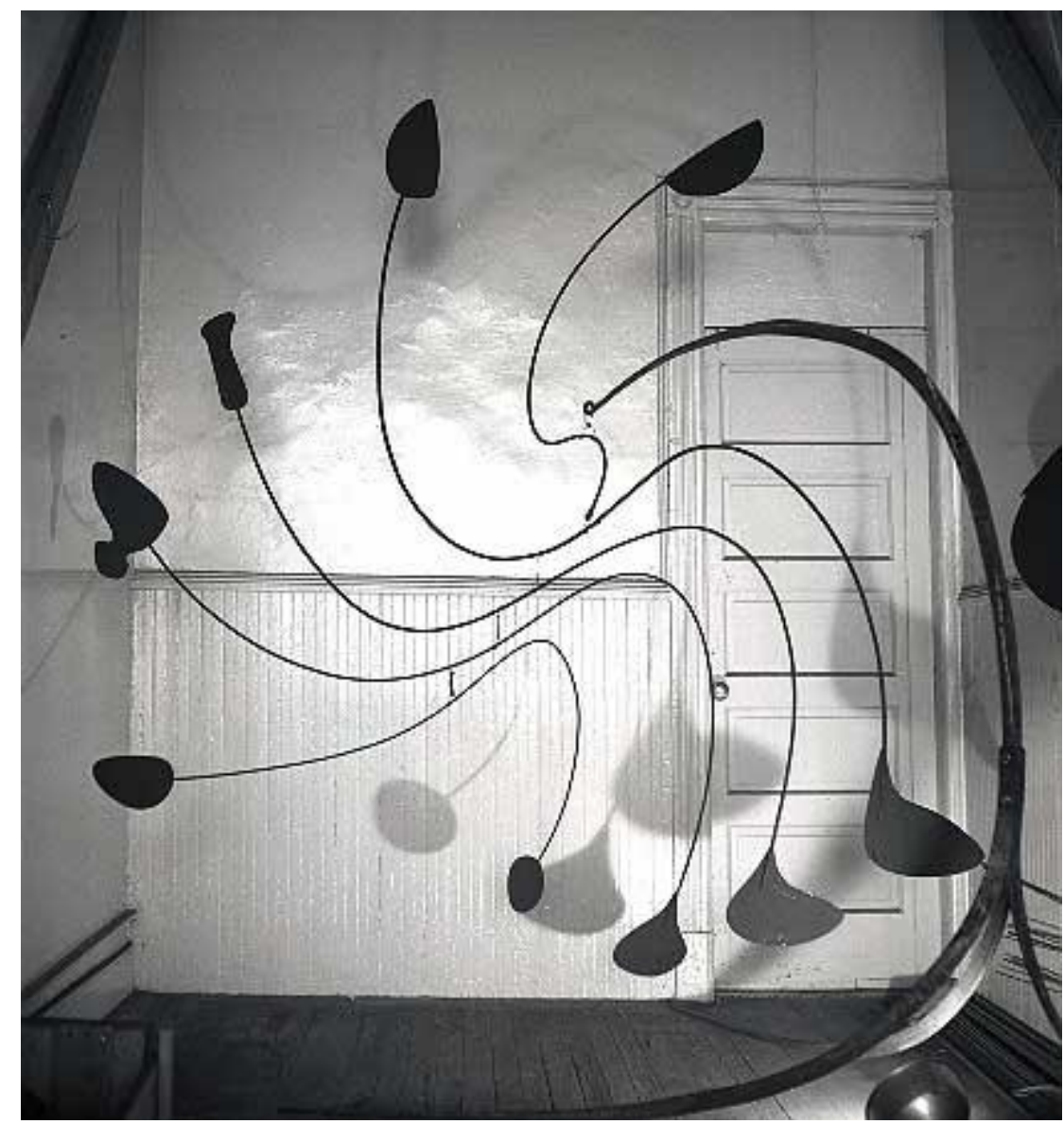

Figura 15: The Spider, 1940 (A09262), in Calder's New York City studio, 1940- Photograph by Herbert Matter Fonte: http://calder.org/archivalphotos/index/80.html

Toda a dramatização da obra de Calder se baseia na dinâmica entre a matéria e as forças físicas do movimento, da tensão, do equilíbrio e da inércia. Esta dinâmica, no entanto, somente se desenvolve fundamentada em um espectro de relações no espaço e no tempo. Assim, o que mantém a coesão do conjunto dos móbiles de Calder são as propriedades gestálticas que asseguram a diferenciação do espaço, ou seja, a distinção entre figura- fundo, cuja influência resulta na unidade visual de suas obras. Unidade esta assegurada pelo movimento plástico que envolve cada parte da obra que se constitui o todo do conjunto.

A revolução trazida por Calder não está na engenhosidade do objeto, porém na capacidade de explorar as relações provenientes do binômio percepção- imaginação. Nesta direção, a teoria gestaltica ofereceu à Mário Pedrosa o subsídio perceptivo e analítico para que fosse possível identificar, e analisar em perspectivas estéticas, as contribuições de Calder quanto à ruptura na relação obra/espectador e artista/criação. Instrumentalizado pela teoria psicológica da forma, Pedrosa pode desenvolver uma série de considerações que se pautaram em novas conotações do objeto artístico e de novas possibilidades perceptivas que este é capaz de oferecer. 
As análises de Pedrosa, sob o ponto de vista gestáltico, assinalam que o real sentido criativo da obra de Alexander Calder não está encerrado na condição matérica de seus artefatos artísticos, ou em suas qualidades estéticas, mas a força de seu argumento reside nas relações estabelecidas com elementos externos ao criador e à obra, que são o entorno, o acaso e a imaginação plástica do espectador.

Pedrosa identifica na obra de Calder, uma maneira completamente nova de a obra de arte "acontecer". Pelos conceitos da estética tradicional, os móbiles de Calder seriam definidos como esculturas cinéticas de "conteúdos abstratos", uma vez que sua constituição formal é estranha à realidade. No entanto, sob ponto de vista da gestalt, estes móbiles ou mesmo os estábiles, podem ser vividamente reais, se assim a capacidade perceptiva e imaginativa do espectador os definir como tais.

A ciência gestáltica considera as relações espaciais e figurais como componentes essenciais na percepção da forma. Esta, por sua vez, compreende o fenômeno artístico como totalidade e não como parcialidades e considera que, as relações existentes entre as formas incompletas, podem ser unificadas através da percepção. Ao assinalar os vínculos entre os elementos da obra, Pedrosa completa o sentido do todo: "É só quando os movimentos das partes se realizam por inteiro que se delineiam perfeitamente acabados, os contornos do objeto na sua forma integral e última."

A partir do princípio que as formas são virtuais e instáveis, estes objetos cambiantes no espaço, abarcam ainda a sedução do inacabado, ou daquele que constantemente se refaz e incita à participação imaginativa e criativa do espectador que o estabilize em uma idéia. Neste jogo entre movimento/ repouso, equilíbrio/desequilíbrio, caos/imaginação, a tensão da obra desestabilizada pelo movimento é controlada pela coesão interna das relações estruturantes da percepção. O jogo é mediado então, pela tensão das partes e pela coesão do conjunto. Nestes termos, Pedrosa estabelece distinções entre os móbiles e estábiles, enquanto conjuntos estruturais, distintos, quase opostos. Quando há maior coesão e estabilidade, como nos estábiles ou nos móbiles motorizados, restringe-se o mecanismo à movimentos únicos e repetitivos. Verifica-se uma menor tensão espacial, pois não se cria uma circunstância instável que ameace a estrutura total. No entanto, a obra de arte fica condicionada à um movimento programado e previsível. Em contrapartida, onde há maior tensão, como nos móbiles de movimentos livres, há menor coesão, devido à flexibilidade da composição e de sua variabilidade sistemática. Esta flexibilidade, no entanto, traz consigo a espontaneidade, a

\footnotetext{
115 PEDROSA, Mário. Tensão e coesão na obra de Calder. In: Modernidade cá e lá. ARANTES, Otília (org.).
} São Paulo: EDUSP, 2000. p.75. 
improvisação e consequentemente, um maior grau de liberdade formal e compositiva. O que se perde em estabilidade, se ganha em plenitude absoluta da forma no espaço.

Assim, Calder traduziu com proficiência as expectativas do crítico brasileiro. Primeiramente pela inserção do artista pelo terreno pedregoso da abstração, e por assimilar, ainda que de forma indireta, as perspectivas das acepções da teoria da forma, como possibilidades de alargamento e reeducação das sensibilidades. Em segunda instância, por alcançar a concepção de uma arte que tem por base o extravasamento da forma no espaço, que se realiza enquanto vibração e enquanto liberdade. Nestes termos, a obra de Alexander Calder corresponde à síntese das expectativas que Mário Pedrosa perseguiu durante toda sua trajetória crítica, uma arte que se apresentasse como "um exercício experimental da liberdade".

Diante do exposto, delineia-se a razão do encantamento e do interesse de Mário Pedrosa sobre a obra de Calder, a ponto de torná-lo o seu artista favorito e de "converter-se" à causa da abstração. Causa esta que defendeu e propagou com tanto afinco em suas críticas e realizações estéticas, especialmente nas experiências concreta e neoconcreta. A obra de Calder foi-nos um perfeito exemplo de modo Mário Pedrosa coadunou os princípios da teoria da forma com a análise e interpretação artística. Sem estes princípios, as peças de Calder seriam somente esculturas. Com o cabedal teórico da gestalt, as peças são seres aptos a terem vida e ritmo, à espera de alguém que lhes forneça o impulso inicial e a sua sensibilidade para experimentar um novo enredo afetivo e estético. 


\section{CONSIDERAÇÕES FINAIS}

A análise atenta da crítica de Mário Pedrosa revela-nos uma visão engajada com a cultura de sua época, e comprometida, não somente com as realidades históricas de seu contexto, mas também preocupada com novas possibilidades perceptivas que expandissem as fronteiras do pensamento. Como crítico, expôs contundentes idéias a favor da arte e de suas perspectivas inovadoras, com a mesma convicção ideológica com que atuou em sua militância política.

Mário Pedrosa foi um intelectual de seu tempo, atento a tudo o que ocorria à sua volta. Suas idéias foram originais e coerentes, e até hoje encontram reverberação no seio da crítica de arte atual. Sua atuação crítica foi de tal modo marcante, que o estudo sobre seus textos se faz conveniente e necessário às investigações sobre a arte brasileira. Foi um intelectual que fez da crítica de arte o seu ofício e, através dela, revolucionou os meios por onde passou. Constituiu-se como uma personalidade que somou à base crítica e intelectual brasileira, uma produção teórica e analítica consistente, de modo que, suas postulações ainda seguem gozando de validades conceituais e estéticas.

Para que seu discurso crítico alcançasse a profundidade poética e formal do objeto artístico, Mário Pedrosa buscou auxílio teórico em demais ciências que lhe fornecesse subsídios para abordagens que escapassem à mera observação impressionista e possibilitasse uma visão consistente e polissêmica. A construção de seu discurso se cercou de diversos instrumentos teóricos e conceituais para que a crítica proferida fosse embasada e criteriosa. $\mathrm{O}$ rigorismo técnico de suas abordagens sinaliza as preocupações do crítico, em manter-se inteirado com as novas descobertas científicas e postulações das ciências humanas, bem como, buscou manter-se pari passu com o processo de modernização de sua época. Foi um dos poucos intelectuais no cenário brasileiro que buscou esse suporte e diversificação de estruturas analíticas. Sua preocupação com as novas descobertas científicas vincularam-no a uma busca constante por atualização e aprendizagem. Esta mesma visão investigativa se refletiu em seus textos críticos.

No seio destas investigações teóricas, pode-se situar o interesse do crítico pelas teses da psicologia da forma, que lhe valeram como uma teoria fundamental para compreensão da arte abstrata. Como uma linguagem que rejeitava qualquer figuração, estava fundamentada nas relações que o cérebro articula com as formas e as cores, e principalmente com novas dimensões de espaço. Os primeiros teóricos desta estética, Kandinsky, Piet Mondrian e Theo 
Van Doesburg, no período da Bauhaus, também imergiram nos estudos da teoria da forma, para ensinar aos alunos os seus pressupostos teóricos necessários, tanto para a concepção, quanto para a compreensão da arte abstrata.

Portanto, desde o seu nascedouro, a arte abstrata foi teorizada com o aporte teórico da psicologia da forma, e neste sentido, torna-se claro que, para compreendê-la, Mário Pedrosa tenha recorrido aos mesmos pressupostos. A sua tese Da Necessidade afetiva da forma na obra de arte revela a acuidade intelectual do crítico, em fundamentar-se nos parâmetros da psicologia e imergir na fisiologia da percepção humana, para, a partir de então, compreender as novas relações cognitivas que a estética abstrata propunha. Somente depois de compreendê-la do interior de sua fundamentação teórica que o crítico investe em sua divulgação e disseminação entre os artistas brasileiros como uma nova linguagem que assinalava a inauguração de todo um vocabulário imagético que se desvinculava completamente da figuração mimética clássica, abolindo quaisquer referências às relações de perspectiva, de figuração e representação.

O esforço desta dissertação se assentou no sentido de traçar um panorama histórico sobre as aproximações entre Mário Pedrosa e às teses da Teoria da Forma. A argumentação arregimentada buscou situar o contato do crítico com estas ideias e identificar, em seus textos críticos, a abordagem destas teorias.

Assinala-se, porém, que a teoria da forma foi um paradigma da linguagem abstrata. Quando o discurso crítico de Pedrosa não mais se dirigiu à esta estética, estas premissas não lhe seriam mais suficientes. Ao interessar-se pelo neoconcretismo, quando a obra de arte ganha a tridimensionalidade, os pressupostos desta teoria não lhe cabem como suporte teórico, uma vez que a relação com esta arte não é bidimensional, mas sim plurisensorial. Os pressupostos gestálticos se mostrariam insuficientes, uma vez que, a arte neoconcreta não mais se centralizava na forma e no objeto de arte, pois as novas relações com a obra de arte passaram a ser espaciais, ou ambientais como disse Pedrosa sobre a obra de Hélio Oiticica.

Neste novo contexto, Pedrosa imerge e incentiva os artistas à dedicarem-se aos estudos da fenomenologia, sobretudo nas leituras de Merleau-Ponty, por considerar ser esta teoria, um arcabouço consistente para a problemática proposta pela arte da década de 1960. Inserido neste contexto outro, quando da publicação de sua tese Da Necessidade afetiva da forma na obra de arte em 1979 que Pedrosa afirma "não ter mais nada a ver com a gestalt", uma vez que esta teoria estava assentava em outras problemáticas de outro panorama artístico e estético anterior àquele da década de 1970. 
Contudo, situado o contexto das décadas de 1940 e 1950, e avaliando o contexto dos estudos sobre a arte abstrata, e as bases teóricas que tais artistas desenvolviam, nota-se uma concatenação direta entre os estudos desenvolvidos por Mário Pedrosa sobre as teses gestálticas e sua preocupação em compreender os pressupostos teóricos da arte abstrata, como maneira de especializar-se para então, dissertar sobre ela em suas críticas. Assim sendo, o fato de Pedrosa ter dito em fins da década de 1970 que não tinha mais relação com a gestalt, não invalida todo o seu esforço de compreensão daquela teoria que fora fundamental na elaboração e desenvolvimento da própria estética abstrata. Faz-se necessário o reconhecimento do pioneirismo e da importância que a tese de 1949- estudo sistemático em que o crítico relaciona gestalt e arte- teve para a época em que tais pesquisas da forma tiveram seu lugar em relação às demandas artísticas. Assim, associar este período do percurso intelectual de Mário Pedrosa a uma citação descontextualizada é incorrer em sério anacronismo e anular a historicidade que cada período traz em seu bojo, como se pudéssemos fazer tabula rasado passado.

Sobre a abordagem inédita de Mário Pedrosa, exclama Frederico Morais:

Como não considerar o pioneirismo de Pedrosa em sua tese sobre a Gestalt, que é de 1949, na qual procura aprofundar o exame do conceito de forma no sentido de definir sua especificidade, sua "lógica interna", ou seu esforço por renovar o vocabulário crítico face às novas realidades plásticas, que por sua vez indicam uma maior proximidade com a ciência (...)? (MORAES, 2004, p 16)

O reconhecimento expresso na afirmação do crítico contemporâneo soma-se à tessitura de nosso argumento. O crítico Frederico Morais assinala-nos a importância dos estudos desenvolvidos por Mário Pedrosa face ao contexto em que se assentou. Frederico aponta a preocupação de Pedrosa com o conceito de forma, com o intuito de instrumentalizar-se para constituir uma crítica adequada às demandas teóricas de sua realidade estética.

A produção crítica Pedrosa valeu-se de diversas teorias de apoio que lhe embasaram a argumentação. Sua produção somente pode ser compreendida à luz de uma perspectiva histórica e do debate com o qual ele dialoga. Como teoria norteadora destaca-se o marxismo clássico, que se relaciona à utopia da Revolução Social que seguiu o crítico durante todo seu percurso. Como aporte estético influem a teoria da gestalt e posteriormente a fenomenologia, que se vinculam às problemáticas em diálogos com seus contextos.

Sobre estas filiações de Mário Pedrosa, explicita-nos claramente o estudo de Ribeiro:

(...) são três os alicerces que estruturaram pensamento crítico e estético de Pedrosa. Eles podem até ter oscilado em sua intensidade de atenção dispensada pelo crítico em seus textos, mas nunca nenhum se omitiu. O primeiro é o marxismo, pela sua 
formação política; depois a gestalt, pela sua crença em uma nova educação estética com o esclarecimento da percepção que é comum a todos os homens e como modelo Baudelaire, por causa da vontade de ter uma visão abrangente, ou melhor, panorâmica passional ao encarar a sua sociedade e falar francamente sobre sua cultural" (RIBEIRO, 2001)

Assinala-se com estas citações que a gestalt não foi somente um estudo auxiliar as pretensões teóricas de Mário Pedrosa. Ela constituiu-se, no percurso intelectual do crítico, como uma fase importante que marcou a sua produção e o seu compromisso com uma estética da forma, e com as possibilidades cognitivas que a arte poderia gerar em seus espectadores.

Os esforços desta pesquisa se articularam no sentido de elucidar este panorama, para somar contribuições ao estudo das idéias de Pedrosa e reverberar os debates que em seus textos são propostos. Seu discurso, como um pensamento deveras consistente, arregimenta possibilidades críticas enriquecedoras, tanto em substratos teóricos, quanto em abertura de visualidades plásticas que resistem ao tempo, e ainda hoje, incita-nos ao debate. 


\section{REFERÊNCIAS}

\section{BIBLIOGRAFIA ESPECÍFICA DE MÁRIO PEDROSA}

PEDROSA, Mário. Arte Necessidade Vital. RJ: Casa do Estudante do Brasil, 1949.

Editora Perspectiva, 1981.

(org. Aracy Amaral) Dos Murais de Portinari aos espaços de Brasília .SP: .(org. Aracy Amaral) Mundo, Homem, Arte em Crise. SP: Perspectiva, 2007.

Paulo: Edusp, 1995.

.(org. ARANTES, Otília)) Mário Pedrosa: Política das Artes (vol. 1). São .(org. ARANTES, Otília) Mário Pedrosa: Forma e Percepção Estética (vol. 2). São Paulo: Edusp, 1995.

3). São Paulo: Edusp, 1995.

.(org. ARANTES, Otília) Mário Pedrosa: Acadêmicos e Modernos (vol. .(org. ARANTES, Otília) Mário Pedrosa: Modernidade Cá e Lá (vol. 4).

São Paulo: Edusp, 1995.

. Obras Completas: As bienais de São Paulo. Otília B. F. Arantes (org.), revisão e normalização Iná Camargo Costa, volume 02, S.L.,S.N., 198- (Cópia no Museu de Arte Contemporânea da USP).

\section{BIBLIOGRAFIA SOBRE MÁRIO PEDROSA:}

ALAMBERT, Francisco. "Milliet- Pedrosa: Aproximações rumo à ação socializadora da arte" In: GONÇALVES, Lisbeth Rebollo. Sérgio Milliet, 100 Anos: Trajetória, Crítica de Arte e Ação Cultural. São Paulo: ABCA/Imprensa Oficial, 2005.

ARANTES, Otília. Mário Pedrosa: Itinerário Crítico. Scritta Editorial. São Paulo, 1991.

BRITO, Ronaldo. As lições avançadas do mestre Pedrosa. Opinião número 152. Rio de Janeiro, 1975.

DIONÍSIO, Gustavo H. O Antídoto do mal-Sobre arte e loucura, Mário Pedrosa e Nise da Silveira. 164f. Manuscrito-Instituto de Psicologia, Universidade de São Paulo. 
GERCHMANN, Miriam Ida. O abstracionismo geométrico na concepção de Mário Pedrosa: A relação com o desenvolvimentismo.295f. Dissertação- História do Brasil- Instituto de Filosofia e Ciências Humanas, Pontifícia Universidade Católica do Rio Grande do Sul.

MARI, Marcelo. Estética e Política em Mário Pedrosa (1930-1950). São Paulo, 2006, 283 f. Tese (Doutorado em Filosofia) Faculdade de Filosofia, Letras e Ciências Humanas da Universidade de São Paulo.

. Mário Pedrosa e Ferreira Gullar: sobre o ideário da crítica de arte nos anos 50 e 60. São Paulo, 2001. Dissertação (Mestrado em Artes) Escola de Comunicações e Artes da USP, São Paulo, Prof ${ }^{a}$ Orientadora Silvia Miranda Meira.

MARQUES NETO, José Castilho. Solidão Revolucionária. Mário Pedrosa e as origens do trotskismo no Brasil. SP: Ed. Paz e Terra, 1993.

Fundação Perseu Abramo, 2001. (org) Mário Pedrosa e o Brasil. São Paulo: Editora

RIBEIRO, Fabiana W. P. Botânica no Asfalto, as lições do Militante Mário Pedrosa. Rio de Janeiro, 2001.110 f. Dissertação (Mestrado em História Social da Cultura) Departamento de História do Programa de Pós-Graduação da PUC-RJ.

\section{BIBLIOGRAFIA GERAL:}

ALAMBERT, F; CANHÊTE, Polyana L. As Bienais de São Paulo: da era do museu à era dos curadores (1951-2001). SP: Boitempo, 2004.

ALMEIDA, Paulo Mendes de. De Anita ao Museu. SP: Ed. Perspectiva, 1976.

AMARAL, Aracy. Arte para quê? A Preocupação social na arte brasileira 1930-1970. SP: Nobel, 1984.

Artes Plásticas na semana de 22. SP: Ed. Perspectiva, 1972.

.(coord.) Projeto Construtivo Brasileiro na Arte: 1950-1962. RJ: Museu de

Arte Moderna do Rio de Janeiro; SP: Pinacoteca do estado de São Paulo, 1977.

ARGAN, Giulio Carlo. Arte e crítica de arte. Lisboa: Editorial Estampa, 1995. Arte Moderna. São Paulo: Companhia das Letras, 1999.

Estampa, 1994. FAGIOLO, Maurizio. Guia de História da Arte. $2^{\mathrm{a}}$ edição. Lisboa:

ARNHEIM, Rudolf. Arte e percepção visual- uma psicologia da visão criadora. São Paulo: EDUSP, 1980. 
ARRUDA, Maria Arminda do Nascimento. Metrópole e Cultura: São Paulo no meio do século XX. Bauru, SP: EDUSC, 2001.

BARTHES, Roland. Que é a Crítica? Paris: Seuil, 1964.

BAUDELAIRE, Charles. Sobre a Modernidade. Rio de Janeiro: Paz e Terra, 1997.

BERTOLI. M; STIGGER, V.(org.) Arte, Crítica e Mundialização SP: ABCA: Imprensa Oficial, 2008.

BOSI, Alfredo. Reflexões sobre a Arte. São Paulo: Ática, 1986.

BRILL, Alice. Da Arte e Da Linguagem. São Paulo: Perspectiva, 1988.

BRITO, Mário da Silva. História do Modernismo Brasileiro: Antecedentes da Semana de Arte Moderna. Rio de Janeiro: Civilização Brasileira, 1971.

CANCLINI, Néstor. G. A Produção simbólica. Rio de Janeiro: Editora Civilização Brasileira, 1980.

CARANDENTE, Giovanni. Calder- móbiles y stabiles. Milão: Editorial Hermes, 1968.

CARDOSO DE MELLO, João M.; NOVAIS, Fernando A. "Capitalismo tardio e sociabilidade moderna". In: NOVAIS, Fernando A.; SCHWARCZ, Lilia Moritz (org.) História da vida privada no Brasil. Contrastes da intimidade contemporânea. São Paulo: Companhia das Letras, 1998.

CAUQUELIN, Anne. Arte Contemporânea. SP: Martins Fontes, 2005. Teorias da Arte. SP: Martins Fontes, 2005.

CHIEPP, H. Teorias da Arte Moderna. São Paulo: Martins Fontes, 1990.

COSTA, Cacilda T. Arte no Brasil 1950-2000-Movimentos e Meios. SP: Alameda, 2004.

DANTO, A .C. Após o fim da arte- A Arte Contemporânea e os limites da História. Trad. Saulo Krieger. SP: Odysseus Editora, 2006.

DE SIMONE, Eliana de S. P. Uma aproximação à obra de Käthe Kollwitz. SP, 1993, 144 f. Tese (Doutorado em Artes) Escola de Comunicações e Artes da Universidade de São Paulo.

DEWEY, John. Arte como experiência. São Paulo: Martins Fontes, 2010.

DROSTE, Magdalena. Bauhaus: 1919-1933. China: Taschen, 2010.

DÜCHTING, Hajo. Kandinsky 1866-1944- A Revolução da Pintura. Cingapura: Taschen/ Paisagem, 2007.

EAGLETON, Terry. A função da Crítica. SP: Martins Fontes, 1991. 
EHRENZWEIG, Anton. Psicanálise da Percepção artística- Uma introdução à teoria da percepção inconsciente. Zahar, 1977.

ELIAS, Norbert. O Processo civilizador.Rio de Janeiro: Jorge Zahar, 2008.

FABRIS, Annateresa (org.) Crítica e Modernidade. SP: ABCA: Imprensa Oficial, 2006.

FABRIS, Annateresa; GONÇALVES, Lisbeth R. (Org.). Os Lugares da Crítica de Arte. São Paulo: ABCA: Imprensa Oficial, 2005.

FERREIRA, Glória. (org.) Crítica de Arte no Brasil: Temáticas Contemporâneas. RJ: Funarte, 2006.

FRACCAROLI, Caetano. A percepção da forma e sua relação com o fenômeno artístico: $O$ problema visto através da Gestalt. Aula $\mathrm{n}^{\circ}$ 30-Plástica III, Setor de publicações, FAU-USP, 1952.

FRANCASTEL, P. Arte y Técnica. Valencia: Editora Fomento de Cultura, 1961.

FRAYZE-PEREIRA, João. Estética da Forma: Mário Pedrosa- crítica de arte, psicologia e psicanálise. In: COLÓQUIO UTOPIAS GEOMÉTRICAS E CONSTRUTIVAS- PROJETO ARTE NO BRASIL: TEXTOS CRÍTICOS DO SÉCULO XX, 2007, Faculdade de Arquitetura e Urbanismo da Universidade de São Paulo.

GAY, Peter. A cultura de Weimar. Rio de Janeiro: Paz e Terra, 1978.

GOMBRICH, E. Arte e Ilusão- Um estudo da psicologia da representação pictórica. SP: Martins Fontes, 2007.

A História da Arte. RJ: LTC Editora, 1999.

GOMES FILHO, João. Gestalt do Objeto: sistema de leitura visual da forma. 9. Ed. SP:

Escrituras Editora, 2009.

GONÇALVES, Lisbeth Rebollo. A Arte brasileira no século XX. SP: ABCA: MAC-USP: Imprensa Oficial, 2007.

EDUSP: FAPESP, 1990. Aldo Bonadei: O Percurso de um Pintor. SP: Perspectiva:

GREENBERG, Clement. Arte e Cultura-Ensaios Críticos. SP, Ed ática, 1996.

GUILLAUME, Paul. Psicologia da Forma. $2^{\mathrm{a}}$ ed. SP: Editora Nacional, 1966.

HENLE, Mary.(org.) Documents of Gestalt Psychology. Berkeley and Los Angeles: University of California Press, 1961. 
HERKENHOFF, Paulo. Neoconcretismo: o corpus teórico. Catalogo da exposição Desenhar no Espaço: Artistas Abstratos do Brasil e da Venezuela na Coleção Patrícia Phelps de Cisneros. Fundação Iberê Camargo/ Pinacoteca do Estado de São Paulo, 2011.

HOBSBAWN, Eric. A Era dos extremos. O breve século XX: 1914-1991. São Paulo:

Companhia das Letras, 1995.

JAUSS, H. R. Pour une esthétique de la reception. Paris: Gallimard,1991.

JUNG. Carl G.(org.) O Homem e seus símbolos. RJ: Nova Fronteira, 2008.

KANDINSKY, Wassily. Curso da Bauhaus. Lisboa: Edições 70, 1987.

Do espiritual na Arte e na Pintura e na Pintura em particular. $2^{\mathrm{a}}$ Edição. São Paulo: Martins Fontes, 2000.

Ponto e Linha sobre o plano- Contribuição à análise dos elementos da pintura. São Paulo: Martins Fontes, 2005.

LOPES, Almerinda da Silva. Arte Abstrata no Brasil. Belo Horizonte: C/Arte, 2010.

LOURENÇO, Maria Cecília França. Museus acolhem o moderno. São Paulo: Edusp, 1999.

MALDONADO, Guitemie. Mondrian. Paris: Éditions Hazan, 2002.

MARX, Karl. O 18 Brumário de Louis Bonaparte. São Paulo, Boitempo Editorial, 2011.

PALLAMIN, Vera. Princípios da Gestalt na organização da forma: abordagem bidimensional. São Paulo, 1985. 166f. Dissertação (mestrado) - Faculdade de Arquitetura e Urbanismo, Universidade de São Paulo.

PANOFSKI, E. O Significado nas Artes Visuais. São Paulo: Perspectiva, 1970.

PIERRE, Arnauld. Calder- La sculpture en mouvement. Paris: Découvertes Gallimard, 2009.

READ, Herbert. As Origens da Forma na Obra de Arte. São Paulo: Zahar Editora, 1981.

RICHARD, Lionel. A República de Weimar 1919-1933. São Paulo: Cia das Letras, 1988.

RICKEY, George. Construtivismo- Origens e evolução. SP: Cosac \& Naify, 2002.

SARAIVA, Roberta (org.). Calder no Brasil: crônica de uma amizade. São Paulo: Cosac Naify/ Pinacoteca do Estado, 2006.

VALIER, Dora. A Arte Abstrata. Lisboa: Edições 70, 1986

ZANINI, Walter (org.). História Geral da Arte no Brasil. São Paulo: Instituto Moreira Salles, 1983 (vol. 2). 


\section{CATÁLOGOS}

Mário Pedrosa: arte, revolução, reflexão. Rio de Janeiro: Centro Cultural Banco do Brasil, 1992.

Mário Pedrosa: 100 anos. São Paulo: Fundação Memorial da América Latina, 2000.

DÉGAND, Leon. Abstraction-Figuration. Paris: Diagonale, 1988 (apres. Daniel Abadie).

1949. (org.). Cat. exp. Do Figurativismo ao Abstracionismo. São Paulo: MAMSP,

Käthe Kollwitz. Clube dos Artistas Modernos. São Paulo, 1933.

\section{ARTIGOS EM PERIÓDICOS E REVISTAS:}

ANDRADE, Mário de. “Käthe Kollwitz”, Diário de São Paulo 09/06/1933.

ARANTES, Otília. Mário Pedrosa, Trajetória Crítica. Módulo, RJ Avenir, n 69.44-45, 1982.

BENTO, Antônio. A "gestalt" e os examinadores. Diário Carioca- Artes, 19/01/1951. Documento pertencente ao Acervo Mário Pedrosa na Fundação Biblioteca Nacional do Rio de Janeiro.

CHIARELLI, T.“A Crítica está confinada ás universidades” Porto Alegre, Zero Hora, 20/07/1992.

PEDROSA, Mário.“Observações Críticas sobre os Prêmios da Bienal”. Suplemento Literário, sem indicação do Jornal, 30/11/1963.

SOURIAU, Étienne. Analyses sur PEDROSA, (Mário)- Da Natureza afetiva da Forma na obra de Arte (Rio de Janeiro, 1949, 28/21 cm).In: Revue D'Esthétique, tome trois- fascicules 3 et 4, juillet- décembre 1950. Paris, Presses Universitaires de France. 


\section{ANEXOS}

\section{ANEXO A: DADOS BIOGRÁFICOS- MÁRIO PEDROSA:}

- Mário Pedrosa 1900-1981- nascido no Pernambuco e falecido no Rio de Janeiro.

- $\quad$ 1923- formou-se em direito no RJ

- 1924- muda p/ SP e conhece Mário de Andrade; faz crítica literária no Diário da Noite

- 1926- ingressa no partido comunista e é enviado p/ Moscou p/ cursar Escola Leninista, mas adoece e fica em Berlim

- 1929- volta ao Br; dá início á sua pregação trotskista é expulso do PC

- 1931- funda a editora Unitas

- 1933-estréia na crítica de arte c/ a conferencia sobre "As tendências sociais na arte de Kaethe Kollwitz" no CAM de SP

- 1934- escreve artigos sobre Portinari no Diário da Noite

- 1937- é exilado em Paris; é um dos fundadores da IV Internacional comunista.

- 1939/43- trabalha na União Panamericana em Washington D.C.

- 1945- volta ao Brasil; trabalha no Correio da Manhã com coluna de arte entre 1949/51- depois vai para o Tribuna da Imprensa.

- 1948- influencia a criação do núcleo de artistas abstratos- concretos do RJ

- 1949- concorre á cátedra de Estética e História da Arte da faculdade de Arquitetura e urbanismo da Universidade do Brasil, com a tese sobre a gestalt e a afetividade da forma. Criada A. I.C.A. da qual Pedrosa é membro

- 1952- professor de História no Colégio Pedro II no RJ

- 1953- colabora na organização da II Bienal de São Paulo 
- 1956- integra a comissão de seleção da delegação brasileira para a Bienal de Veneza; apresenta conferência na $1^{\text {a }}$ Exposição Nacional de arte concreta no MAM-RJe SP.

- 1957- assume coluna de arte no Jornal do Brasil; participa da comissão de premiação da IV Bienal de SP;

- 1958- vai para o Japão, comissionado pela Unesco p/ estudar as relações entre oriente e ocidente

- 1959- Organiza o Congresso Extraordinário Internacional de Críticos de Arte, em Brasília, RJ e SP

- 1960- assume o cargo de diretor artístico do MAM-SP; faz parte do júri do IX Salão Nacional de Arte Moderna

- 1961- muda p/ SP e assume a secretaria geral e a diretoria executiva da VI Bienal de SP; é nomeado pó Jânio Quadros como Secretário-Geral do Conselho Nacional de Cultura, mas no mesmo ano pede demissão ; transforma a Bienal de SP em uma instituição pública autônoma; é reeleito vice-presidente da A. I.C.A.

- 1962- o MAM-SP é fechado por seu presidente, Francisco Matarazzo, que doa seu acervo p/ USP; a direção do Museu permanece c/ Pedrosa

- 1963- assume presidência da ABCA

- $\quad$ 1963- eleito p/ integrar o júri de premiação da IV Bienal de jovens de Paris

- 1968- integra o júri da Bienal de gravura da Cracóvia, na Polônia; participa na realização da Bienal local de Nuremberg, dedicada ao construtivismo; fica em Lisboa um tempo por conta do AI-5

- 1969- volta ao Brasil; participa do júri da Bienal de gravura de Tóquio 
- 1970- é processado por difamar o Br no estrangeiro c/ denuncias de tortura, tem prisão decretada e se refugia no consulado do Chile, consegue salvo-conduto e vai p/ Santiago do Chile.

- 1971- participa do júri de premiação da Bienal de Nova Délhi na Índia e qdo volta é encarregado por Allende da organização do Museu de Arte Moderna c/ doações de artistas de todo o mundo.

- 1972- $1^{\mathrm{a}}$ exposição do chamado "Museo de la Solidariedad"

- 1973- Golpe que derruba Allende, Pedrosa refugia-se na embaixada do México, vai p/ Paris com a esposa, na condição de refugiados políticos

- 1974- tenta recuperar obras do Museo de la Solidariedad e o intitula Museu da Resistência

- 1976- em Paris escreve p/ diversas revistas da França, México,Portugal, EUA e Peru.

- 1977- volta ao Brasil, seu mandato de prisão fora revogado

- 1978- organiza uma exposição sobre arte indígena, porém o MAM-RJ é incendiado e a mostra não se realiza; propõe a criação do Museu das origens

- 1979- se empenha na campanha de fundação do PT

- 1980-Várias homenagens são organizadas p/ Pedrosa: a Bienal de SP organiza um evento em sua honra, relança o livro "Arte/ Forma e personalidade" é criado o Premio Mário Pedrosa para artista latino-americano pelo conjunto de sua obra; se filia ao PT como filiado $\mathrm{n}^{\circ} 1$ do Partido.

- 1981-ainda mantém algum projetos em andamentos: uma autobiografia e uma história do Brasil sob ótica dos oprimidos; No dia 5/11 morre vítima de um câncer. 
ANEXO B- CÓPIAS DAS PÁGINAS DO CADERNO DE ANOTAÇÕES PERTENCENTE A MÁRIO PEDROSA.

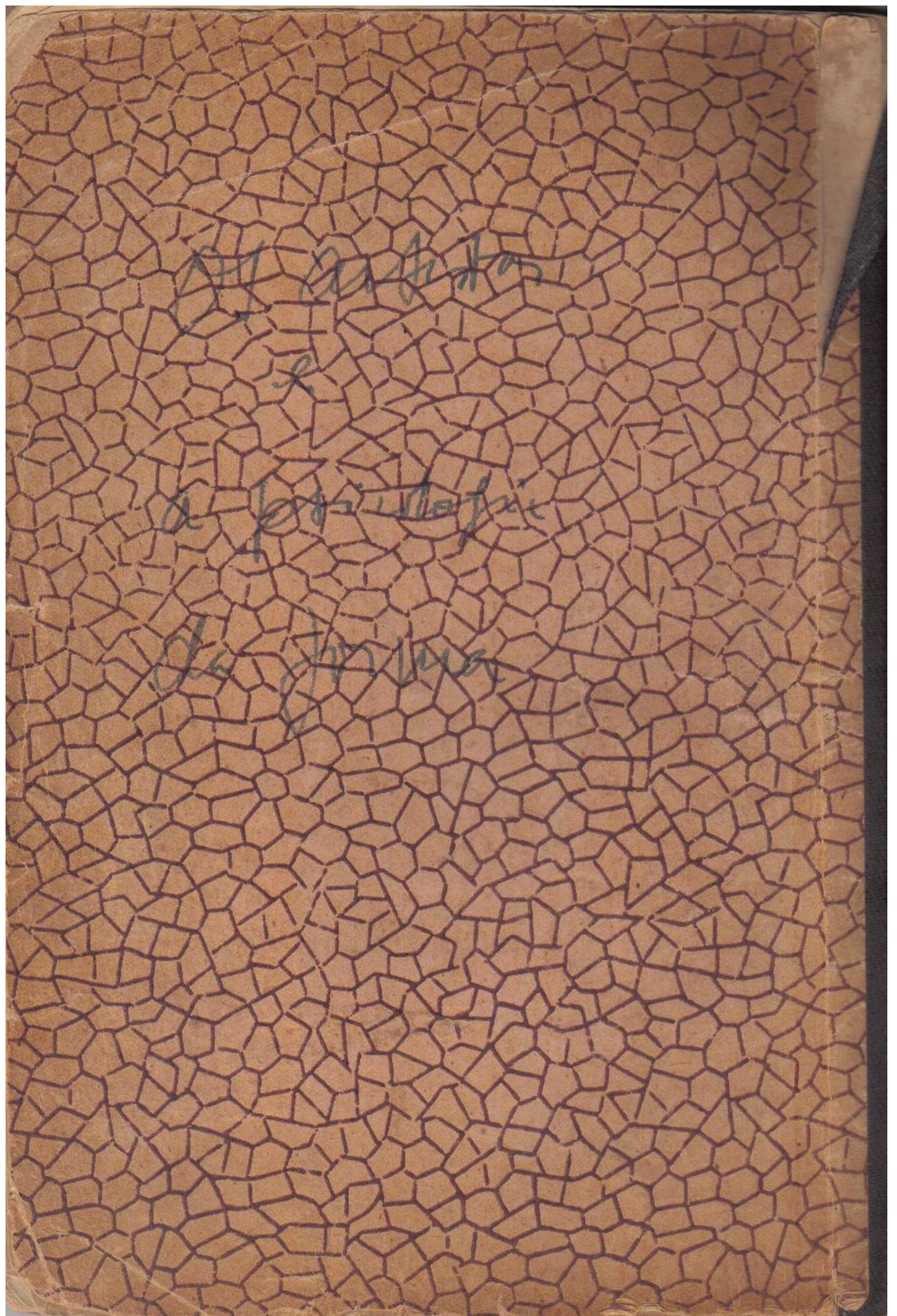

Capa frontal do caderno de anotações- Inscrito com o título "Os artistas e a Psicologia da Forma" 


\section{ANEXO C- CÓPIAS DAS PÁGINAS DO CADERNO DE ANOTAÇÕES}

\section{PERTENCENTE A MÁRIO PEDROSA.}

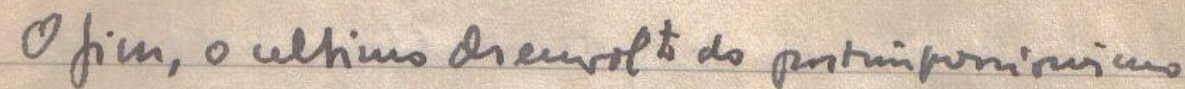

edo chism - é olithacismin

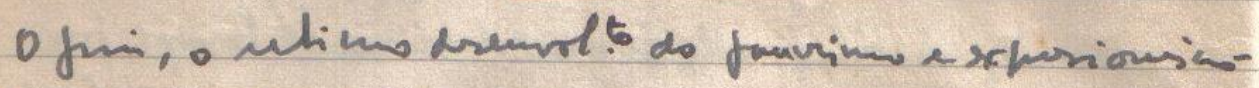
e' surreabions.7

"Mondrian:" Nm-hifout hurand an abtemot of What $s$ ansefrence of Mitask, thi dituction of particula frim and the craturction 8 a rhythm 8 mutual ubtions of mutuat forms is or free lins."

The enilifime (Gince.48) The aprih

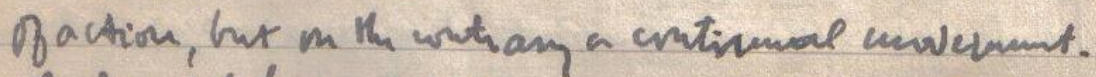

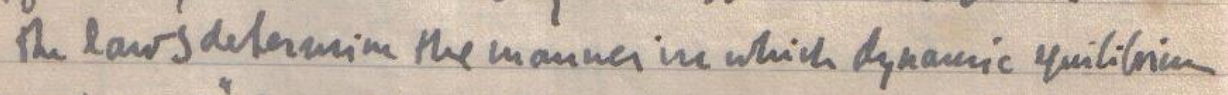
is achieved. The rectirs 1 porition and rosen of dimension

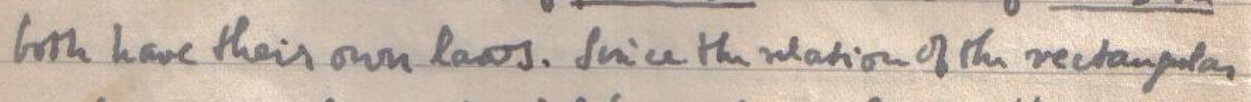

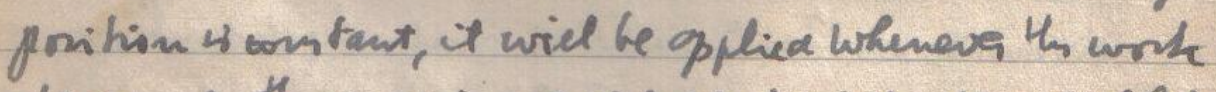

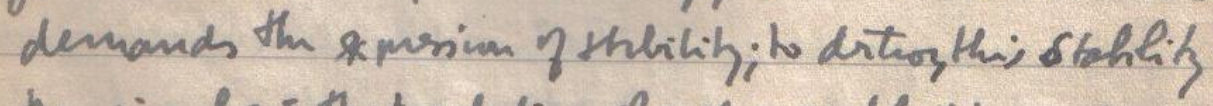
ther si a low that ulations of a changeath dimensioneppriom must be subytituted. Th pet that all the ulation of pritim supht the netroupula one lack that statility, abo neats a haw which we must take into account if something sit be strllished in a determinate manner. Tro offen wifht and khfue anghes are mbitraily euployed.

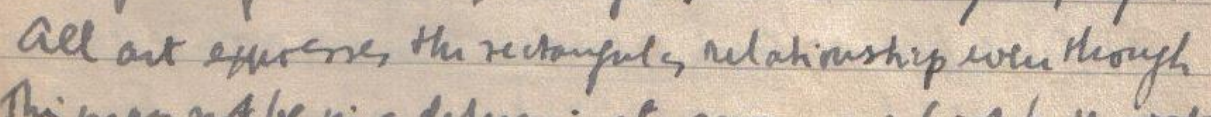
Thimay not be ni a deteminate manmer; fiot by the rotet heripht and widk of the work and its contruetive frans, then by the mutiol aclations of these forms. Thengh the davity

Página com anotações e reflexões que relacionam Mondrian e a estética abstrata. (Destaque em vermelho é grifo nosso). 


\section{ANEXO D- CÓPIAS DAS PÁGINAS DO CADERNO DE ANOTAÇÕES}

\section{PERTENCENTE A MÁRIO PEDROSA.}

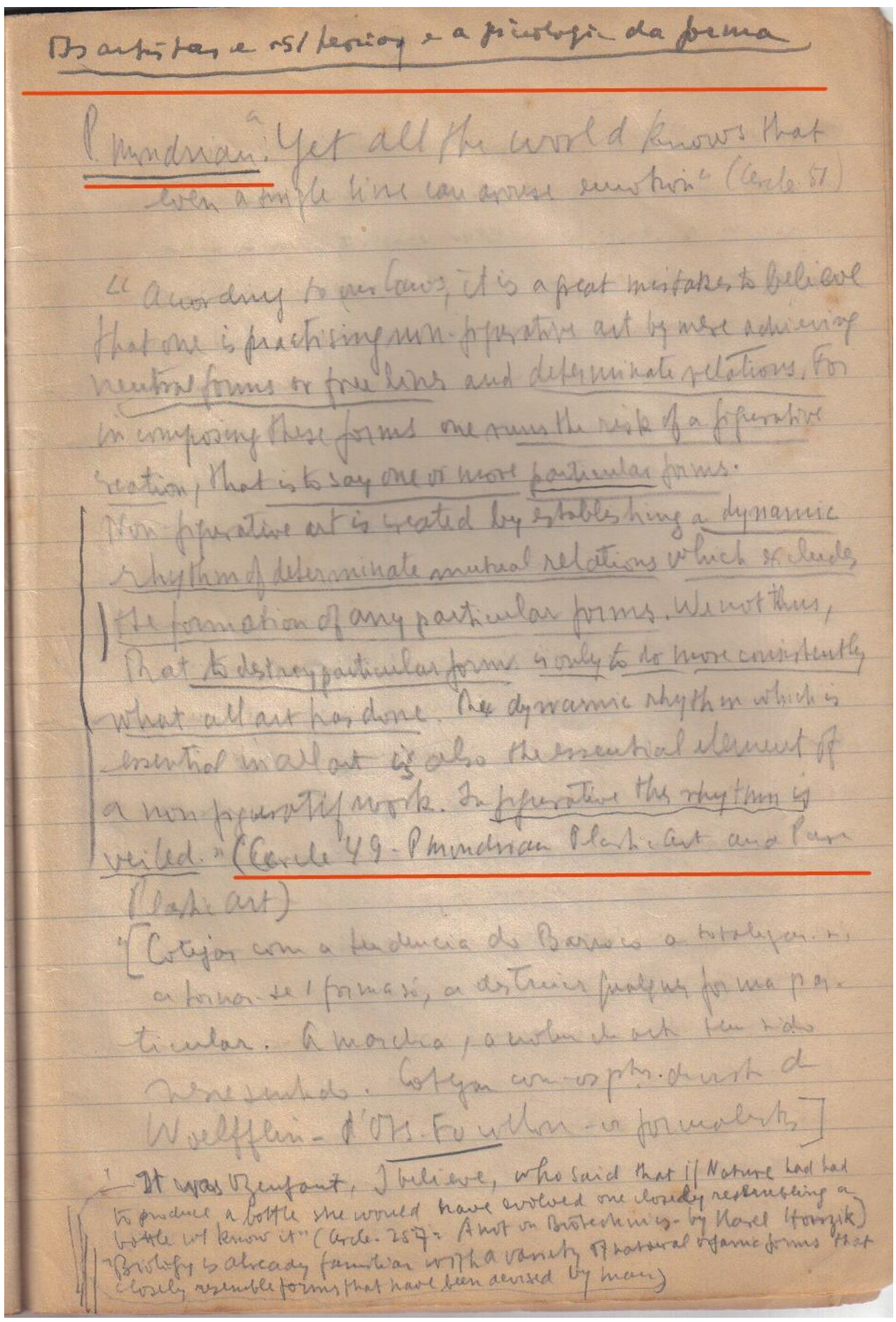

Em destaque, evidencia-se a citação de Piet Mondrian seguido da indicação "Cercle, 57" e "Cercle 49", possivelmente alguma referência às publicações do artista na importante revista Cercle et Carré, que veiculava textos de artistas sobre pesquisas estéticas.

Destaca-se também a primeira linha do texto "Os artistas e as teorias e a psicologia da forma" (Destaque em vermelho é grifo nosso). 


\section{ANEXO E- CÓPIAS DAS PÁGINAS DO CADERNO DE ANOTAÇÕES}

\section{PERTENCENTE A MÁRIO PEDROSA.}

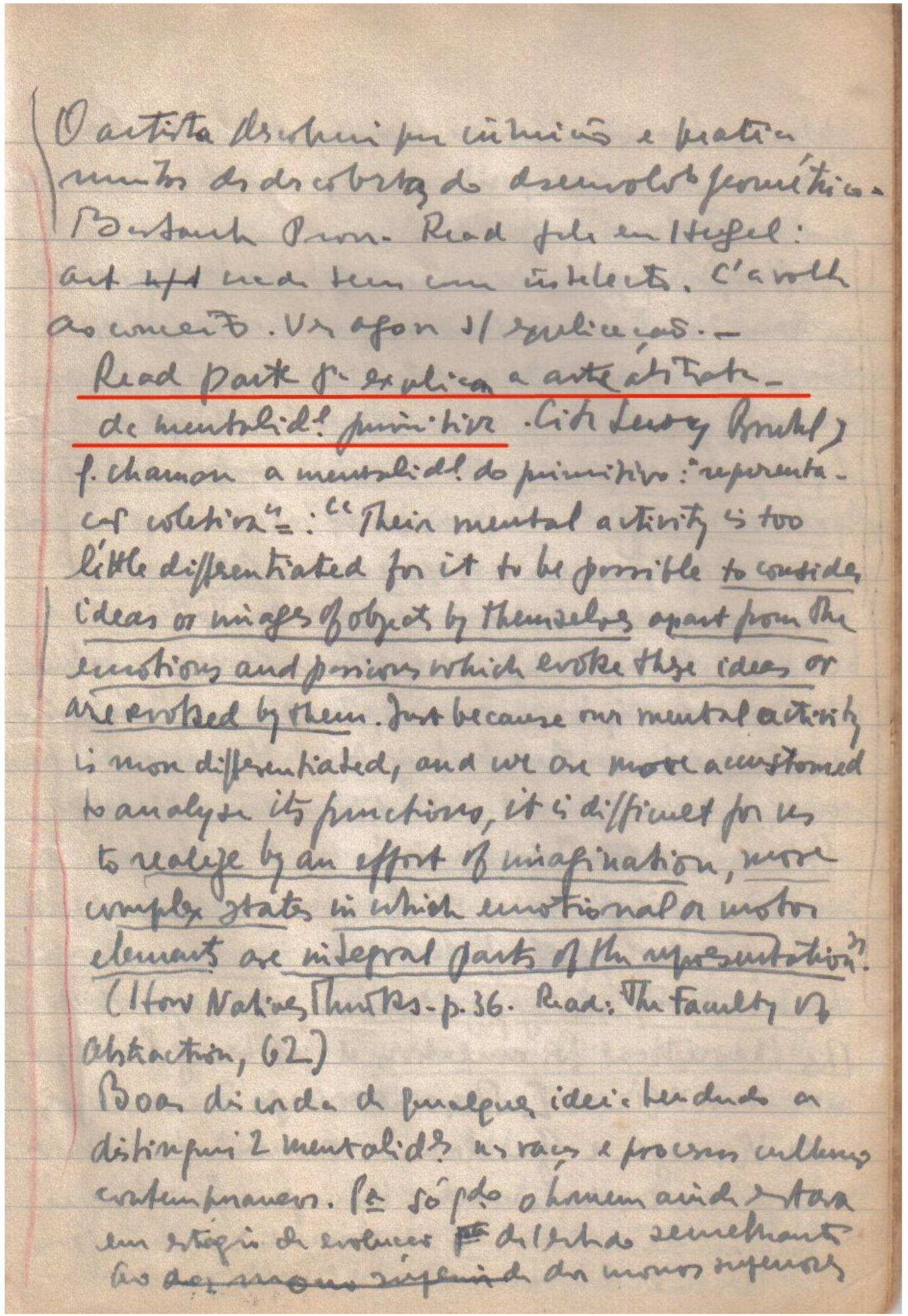

Destacamos com grifo uma das páginas em que o crítico discute as ideias de Herbert Read sobre arte abstrata. 
165

ANEXO F- CÓPIAS DAS PÁGINAS DO CADERNO DE ANOTAÇÕES PERTENCENTE A MÁRIO PEDROSA.

In preptions fareas and thair thepes. Rrs factirs ... are actroy on mu uptical pres of atraction.

The visure freed, the wtina field

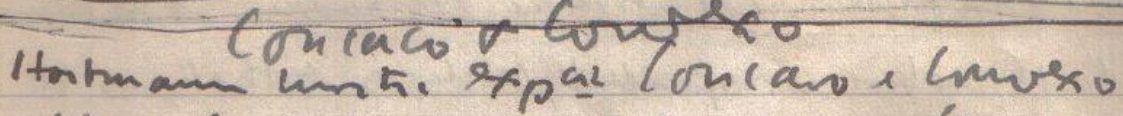

Hotraboptel - ohemen J/ wiveszas ótica.

conchi s. couvexide a concauide sat preprises tors.

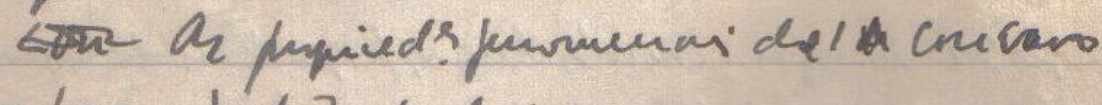
our tipicam! diturh $\alpha$ / courto.

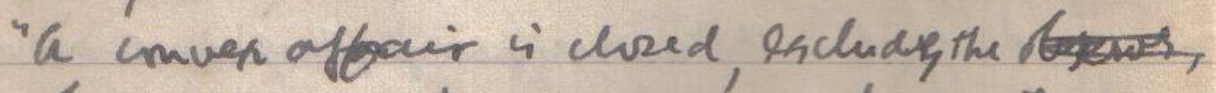

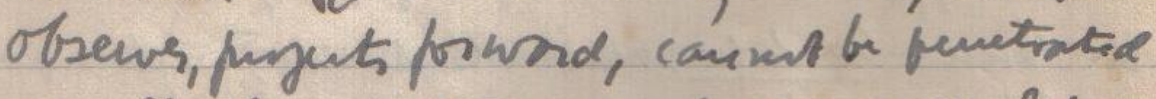
risually becarn fis pacity $n$. maceifualated becase of its mifenctialikity. Vifual "olycs" are unver.

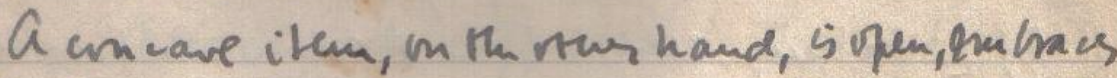
the thewer, permits visual and cuamual yplesahin, and possesses the charactersitics of an leorephy bade fromend. "Spacs" are concaur" (Hout manns 1.108) [or rpacos das en whents; n ryatos

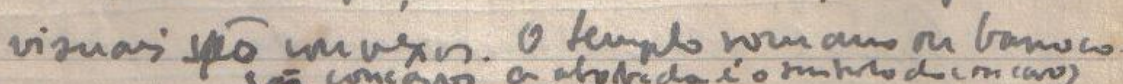

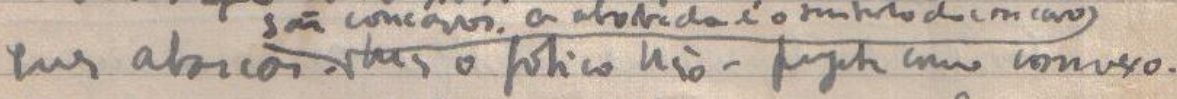

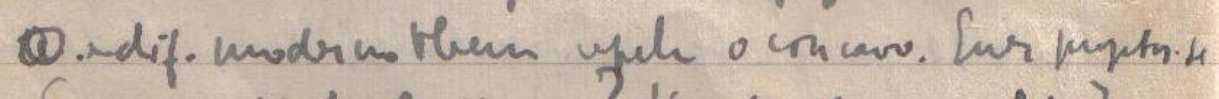

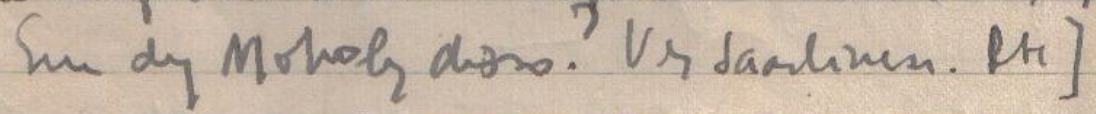

O destaque aponta o teórico Hornbostel sendo discutido nas reflexões de Mário Pedrosa 


\section{ANEXO G- CÓPIAS DAS PÁGINAS DO CADERNO DE ANOTAÇÕES}

\section{PERTENCENTE A MÁRIO PEDROSA.}

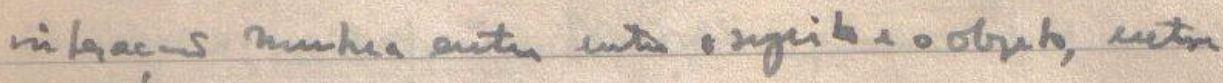

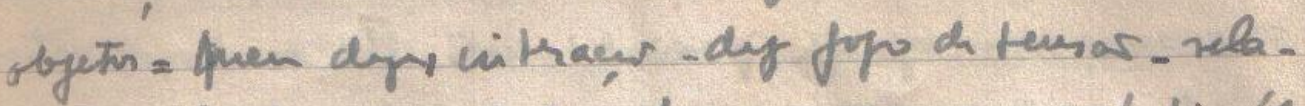

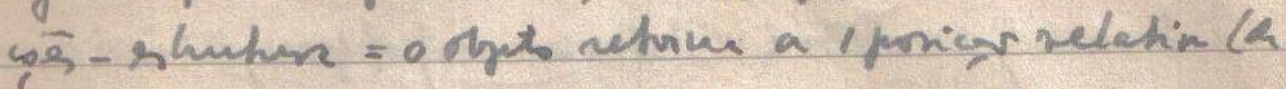
pocepimitin) me em ontatlawo = integer n

$1 \mathrm{~m}$. Matia e sunimf dinamia e netara. Esh pre

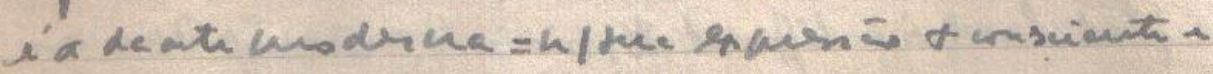

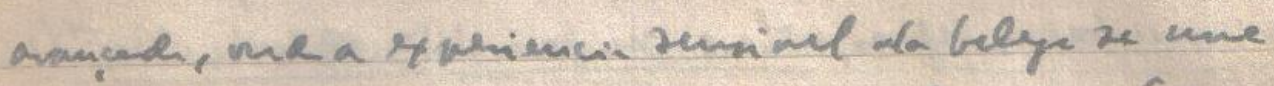

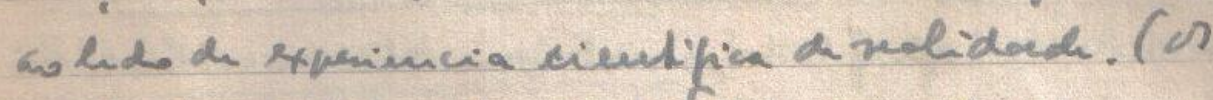

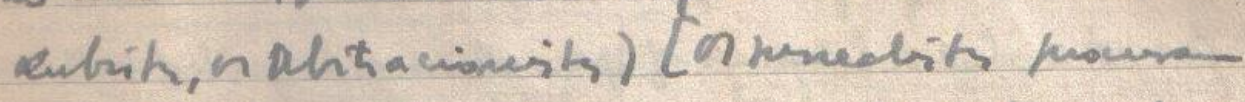

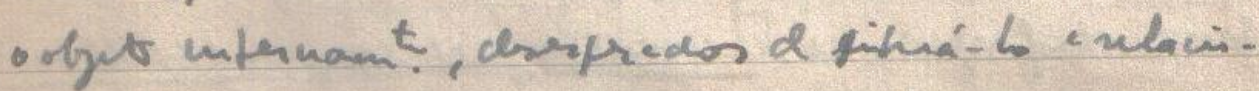

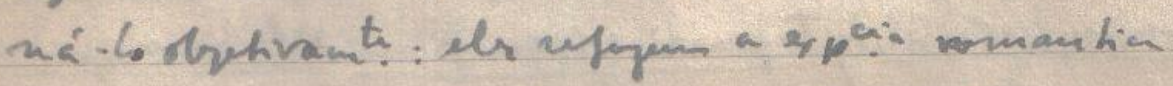

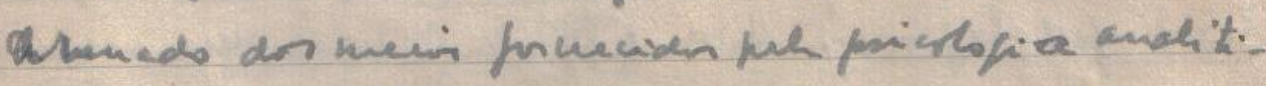

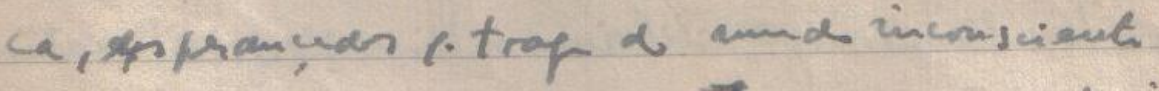

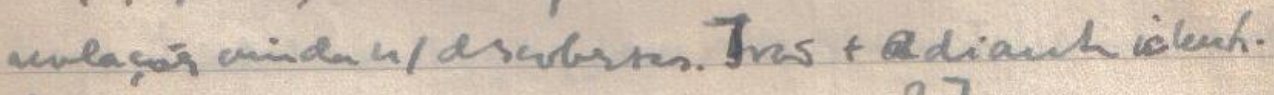

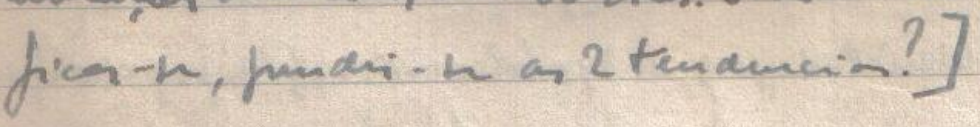

Kepes: "Fopreive a tisua miege mifhis the behot dr's panticipation mi a procen of argemization. The spenience of an

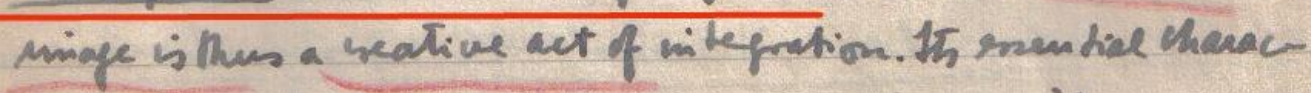

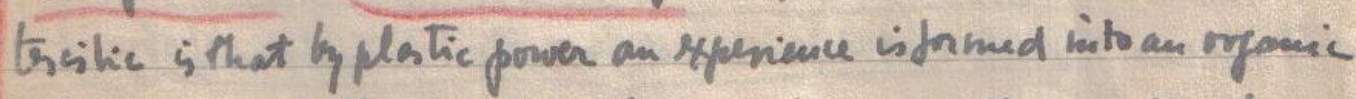
white. Hesci a basie diviplime 1 froming, thats, thinbing

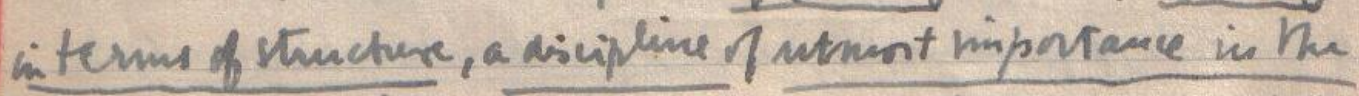

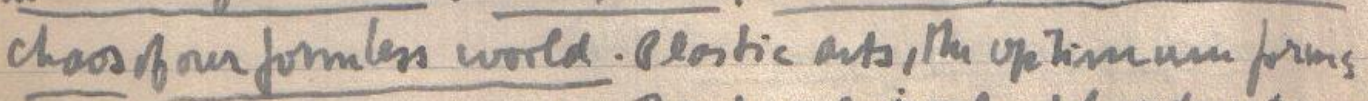
it the langrege of vision, are, theryors an invaluable sda cetinged

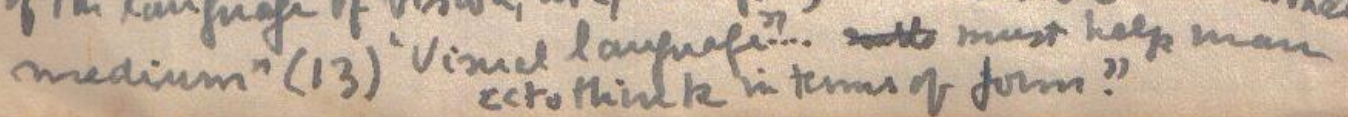

Destaca-se a abordagem de outro teórico da percepção visual, Giorgy Kepes. 


\section{ANEXO H- CÓPIAS DAS PÁGINAS DO CADERNO DE ANOTAÇÕES}

\section{PERTENCENTE A MÁRIO PEDROSA.}

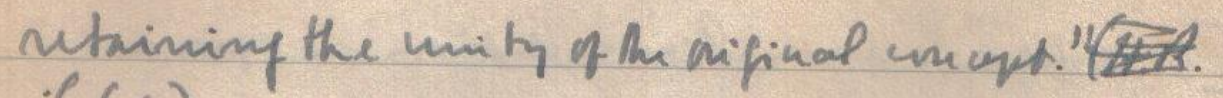

$(65)$

The Languafe of Vision: Gyorgy Kepes

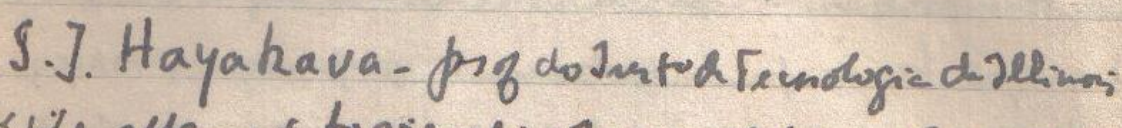

"Whe attempt to vimalige the eventfuluen of a miarse

That is an sectiodyanic plenum in the reperentational elicheis

polved at a time when traticaly- concrived, siolafle abjects"

whe ryarded a couplay pritions wi an supty and abolute "quace". Visendeg, the majicity twe are thief "otget. minded" and " relationes-minded". We are the prisones Ofancient mientations ninbedded vi the lan popes wh heve

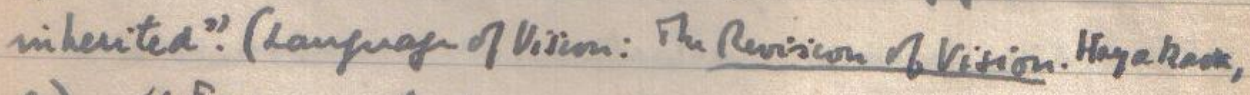

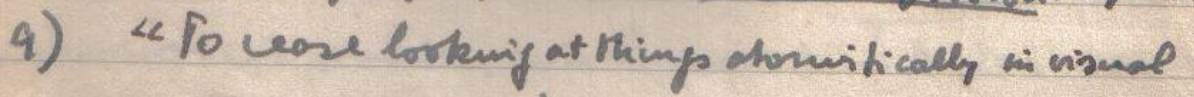

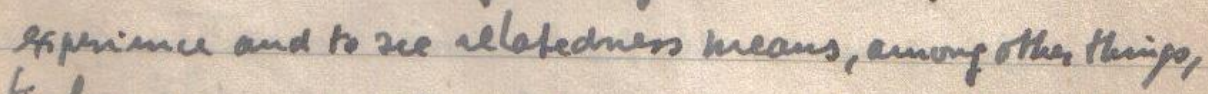

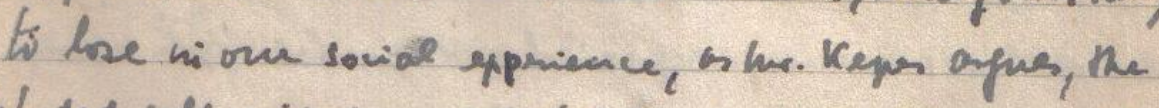

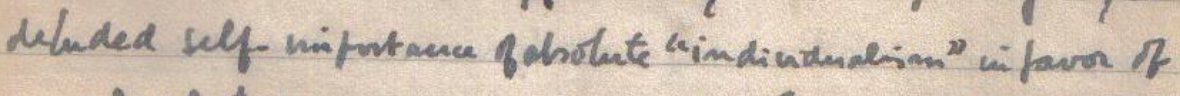

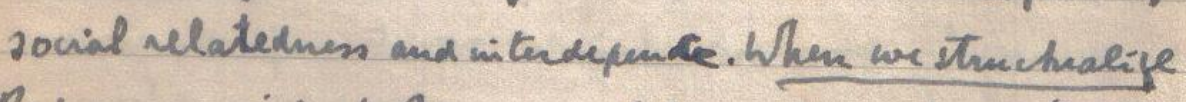

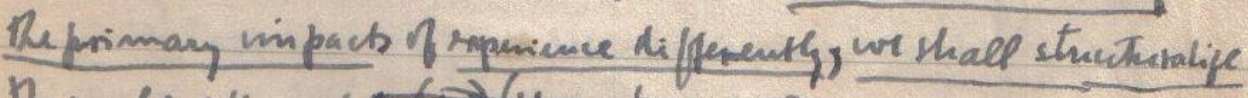

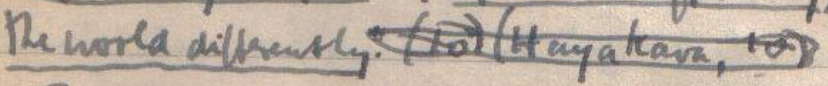

Ne ung. Toner vizual hatits so that we perceive hot ciolated "thing" in "pace", Lut structure, onder, and Mu velatednes Tevents in spece-time, 5 perhapes the most profound kind

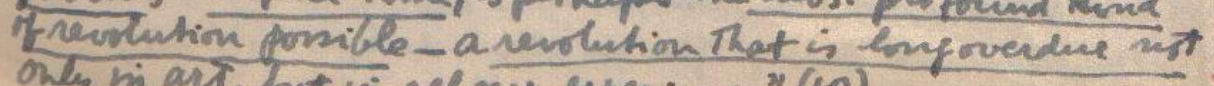

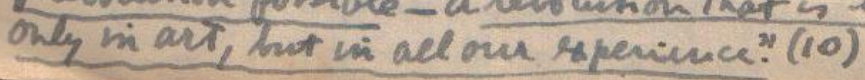

Destaca-se o titulo da obra de Kepes, The language of vision em discussão pelas anotações do crítico. 


\section{ANEXO I- CÓPIAS DAS PÁGINAS DO CADERNO DE ANOTAÇÕES}

\section{PERTENCENTE A MÁRIO PEDROSA.}

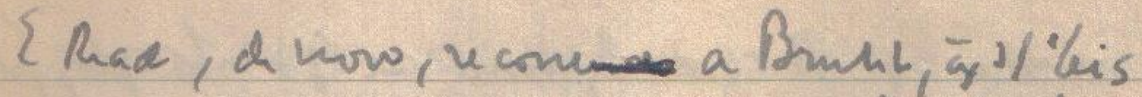

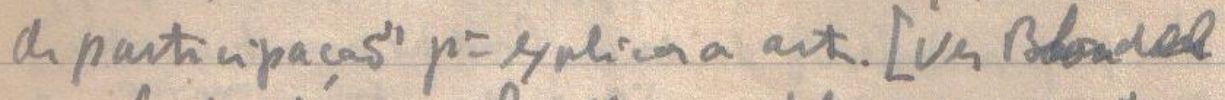
en frhetiann. fuillawm pl whe patin. dacar] Rad : "SF hu artit a for primitive man

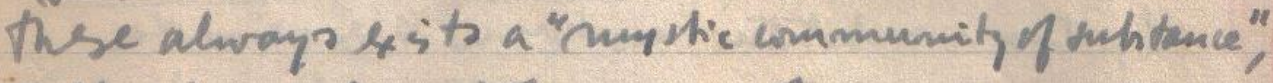
a'pre-Ligical'identification of Noupht andobjet,

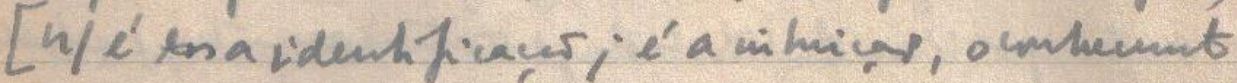
do obet pl suth munt, mik= dirisend-o

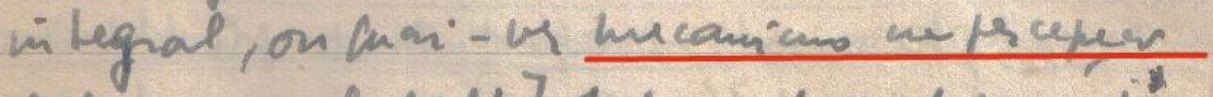

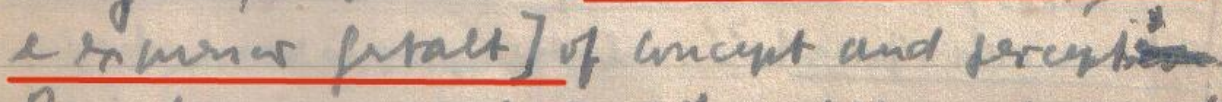
But doy hot uniph mat the chitmust revest to Th primitive thage of mentality. The identification Which s mow refented of him his beyond the coneres.

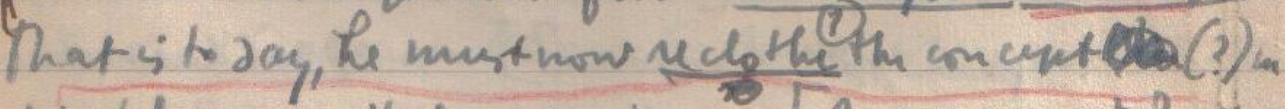
virible and vital raimint. [Pre o concit? aste

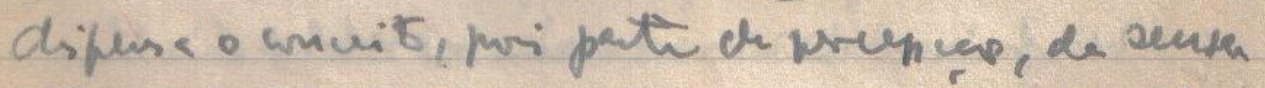

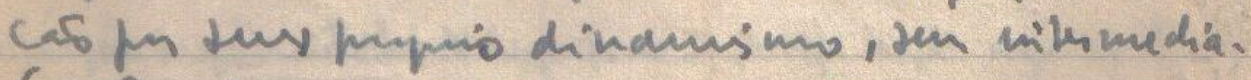

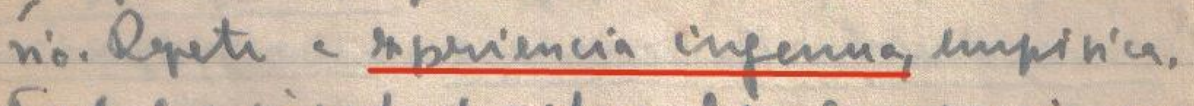

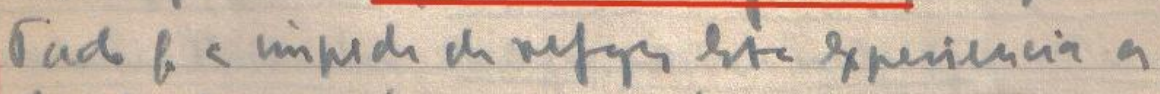

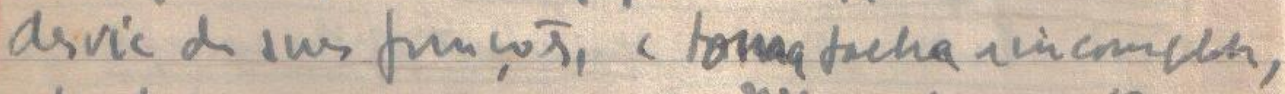

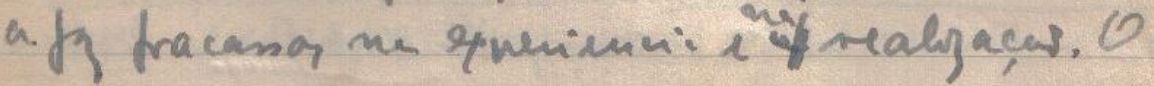

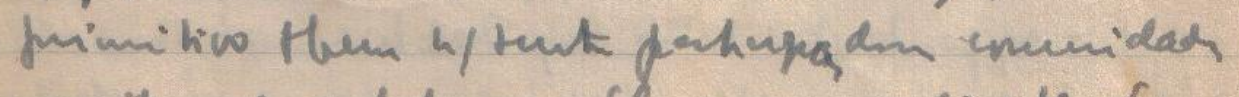
Instan al tuhtancie. Sle aweus + direts é uneun zutndinedo agdicts medians of

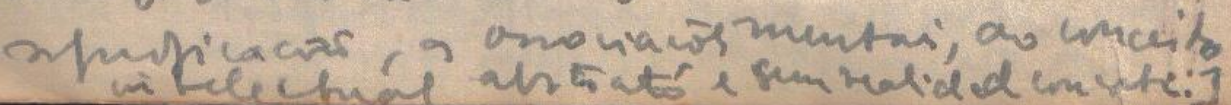

Em seu estudo Da natureza Afetiva da Forma na Obra de Arte, Mário Pedrosa discute largamente o tema da experiência. 


\section{ANEXO J- CÓPIAS DAS PÁGINAS DO CADERNO DE ANOTAÇÕES PERTENCENTE A MÁRIO PEDROSA.}

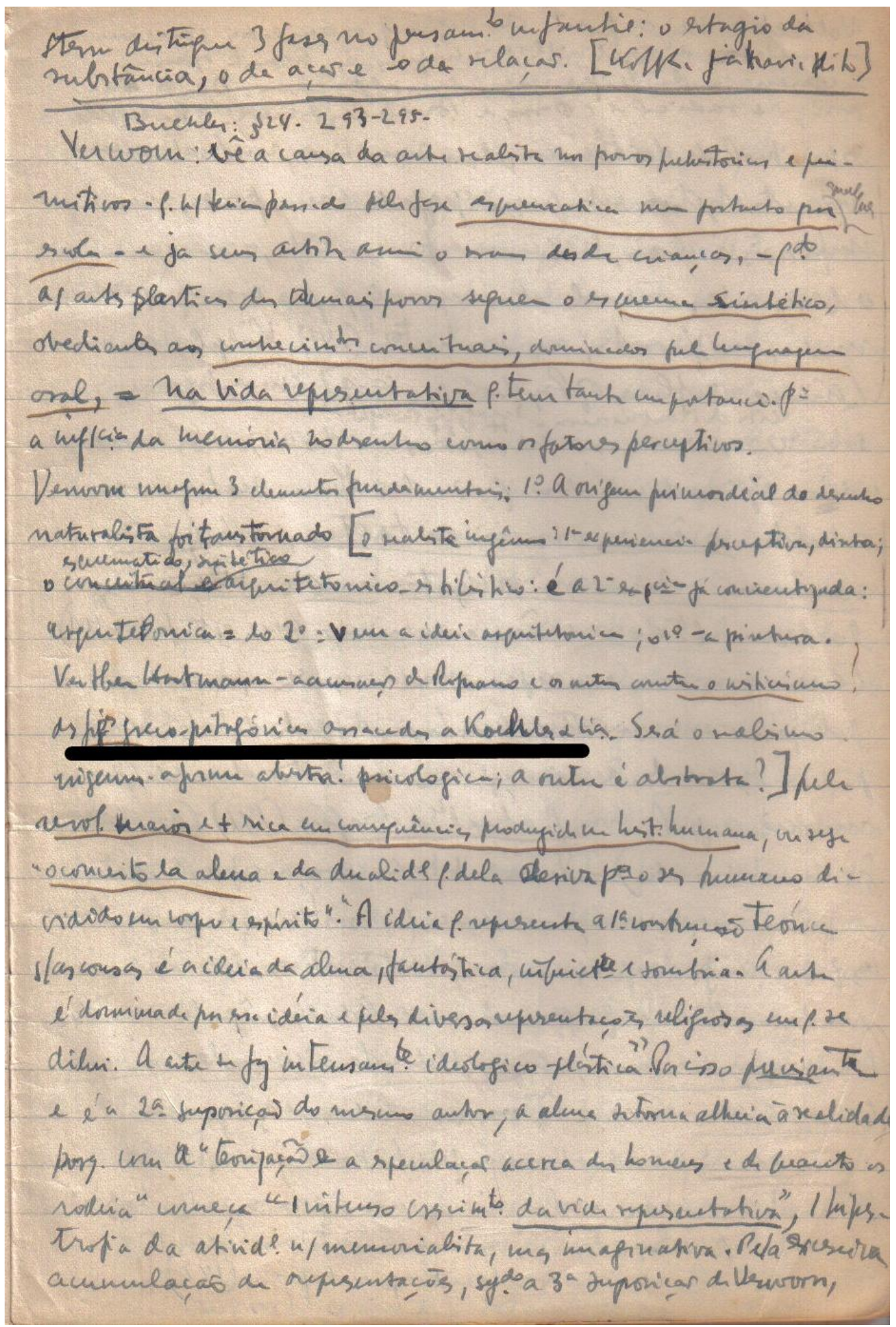

Em destaque, observa-se a referência à Kohler. 


\section{ANEXO K- CÓPIAS DAS PÁGINAS DO CADERNO DE ANOTAÇÕES}

\section{PERTENCENTE A MÁRIO PEDROSA.}

privein Mtrdiod balbucios sem finalide pona-ke unidiates ao de trpenás de algo, sejam aptios on desyos,

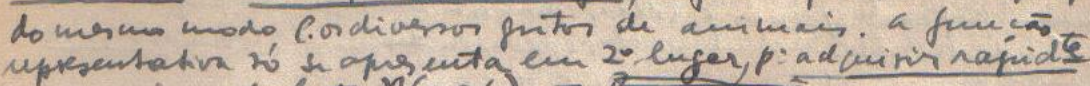

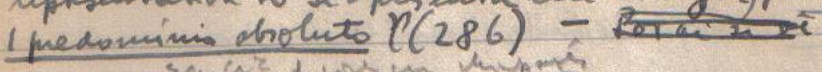

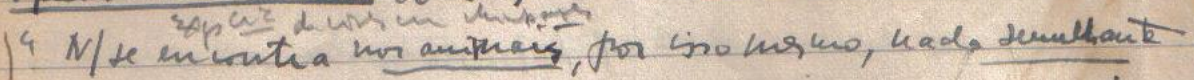

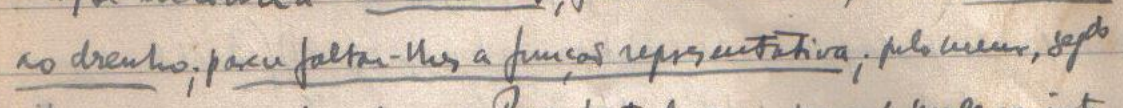

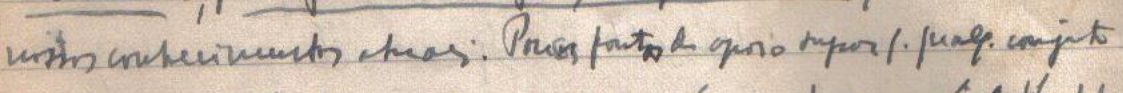

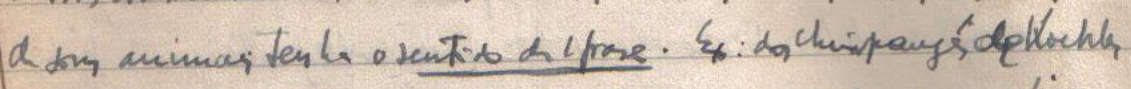

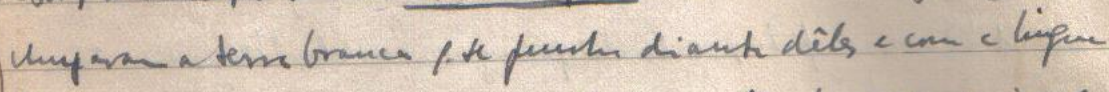

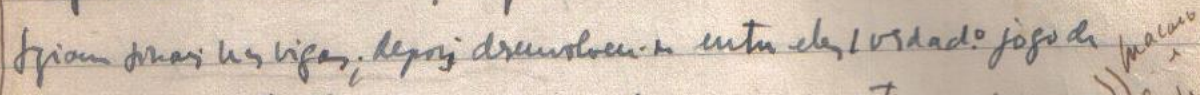

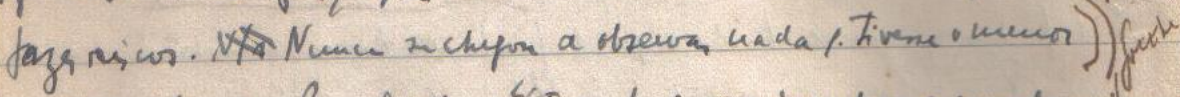

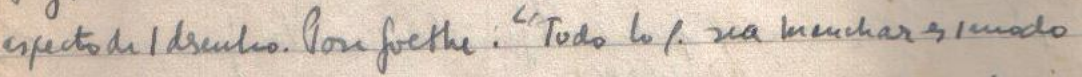

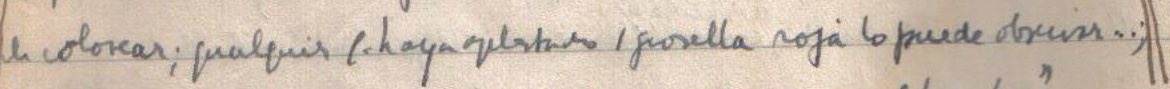

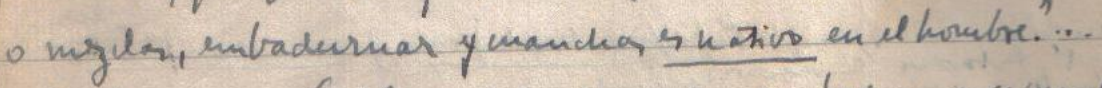

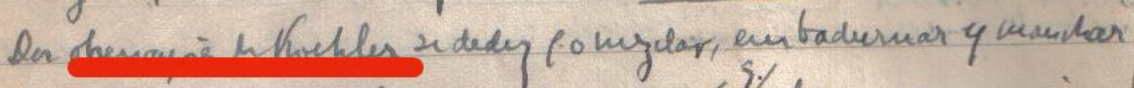

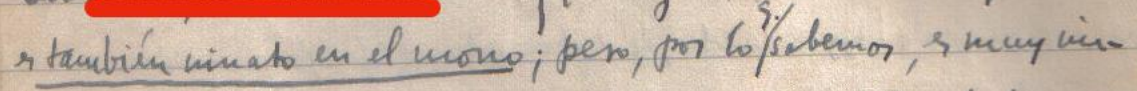
pobble fel mono haya dado nunca Ivalor uperentotivo a

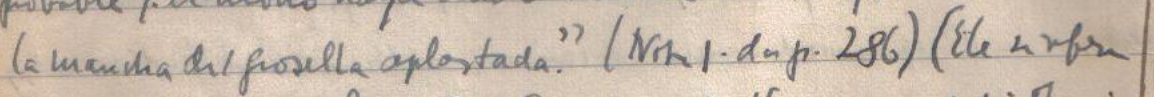
then av ortude di froos: Dir Anfainge der thinst und dis Therie Dawins, Hen. Blattifin Völerteunde, III, tiviueles 2y3)

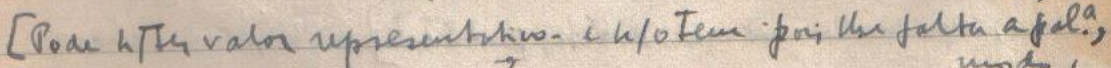

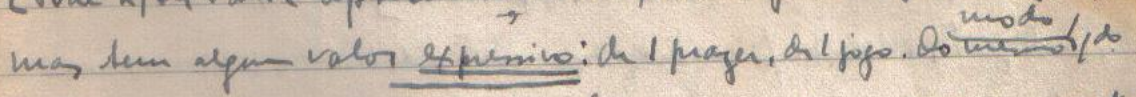

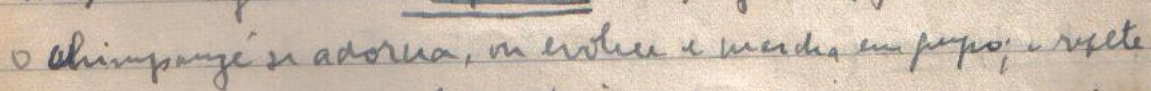

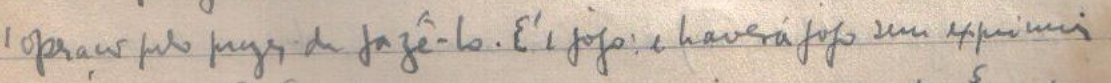

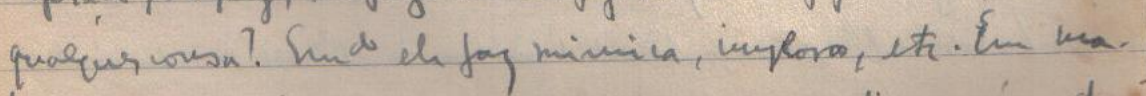

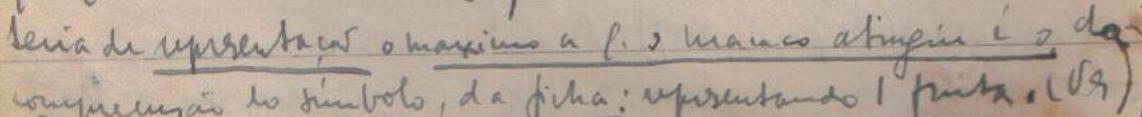

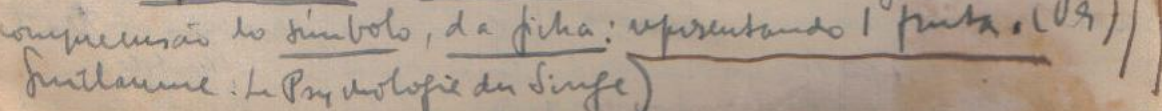

Em destaque, observa-se a referência à Kohler. 


\section{ANEXO L- CÓPIAS DAS PÁGINAS DO CADERNO DE ANOTAÇÕES}

\section{PERTENCENTE A MÁRIO PEDROSA.}

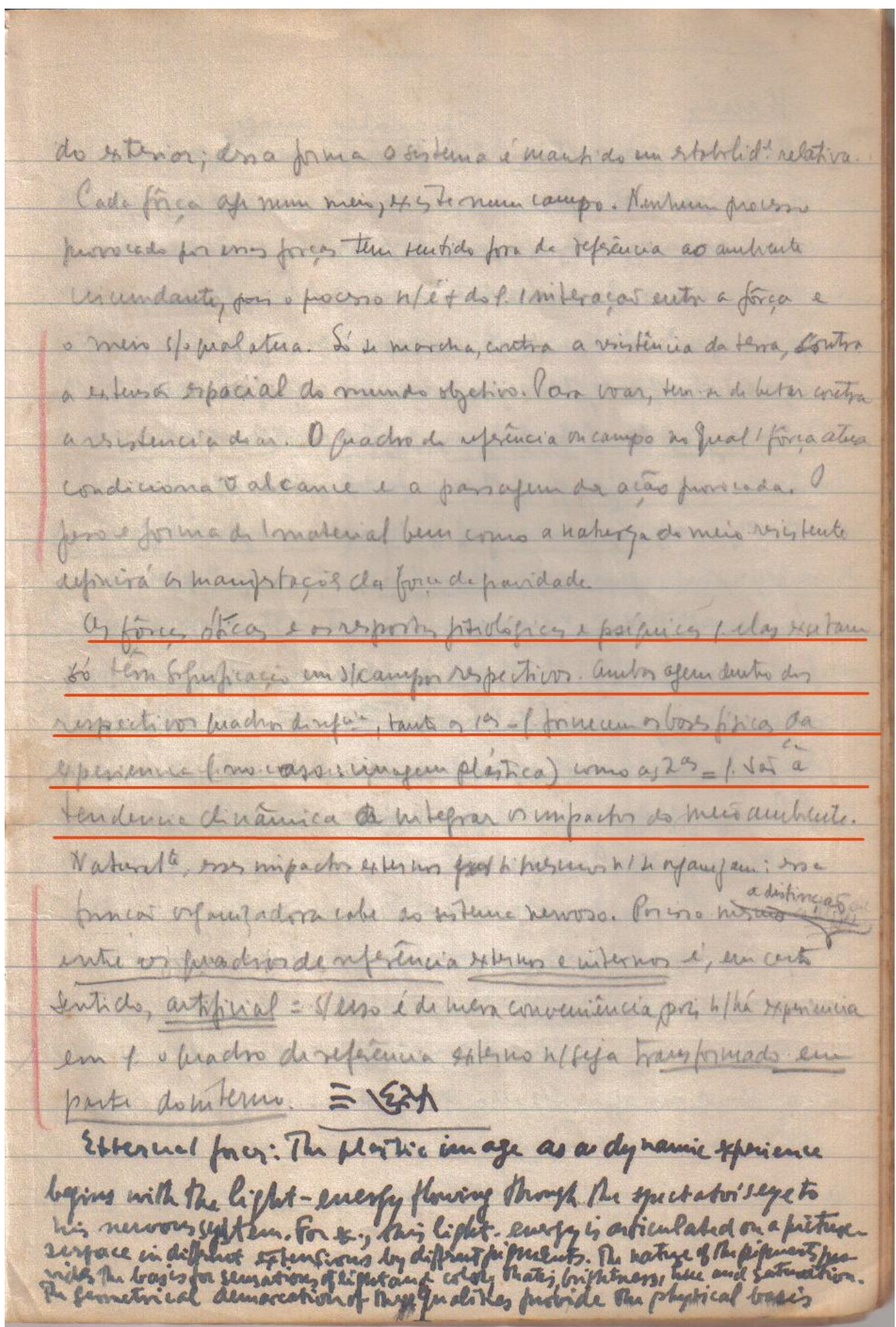

Apontamentos sobre forças ópticas 


\title{
ANEXO M- Reprodução Crítica de Mário Pedrosa: Calder, Escultor de Cataventos In:: SARAIVA, Roberta (org.). Calder no Brasil: crônica de uma amizade. São Paulo: Cosac Naify/ Pinacoteca do Estado, 2006.pp 37-51.
}

\author{
Calder, escultor de cata-ventos \\ Mário Pedrosa
}

Quando os pais de Calder viviam preocupados com os problemas de sua arte, o menino Sandy reagia, num soberano desprezo pelas vãs e infantis preocupações daqueles adultos. De fato, no ambiente artístico em que vivia, descendente de duas gerações de escultores, Sandy tinha assim bastante motivo para desenvolver a sua natural tendência a opor-se ao que é convencional (o convencional na sua casa de artistas acadêmicos era... a arte). Mas esta oposição nunca tomou aspecto feroz, ou violento ou espalhafatoso, porque é sobretudo feita de amor ao contraste, qualidade plástica por excelência, e de senso de independência, faculdades essas que, sem ser animadas pelo ódio ou pela violência, não produzem a revolta do incendiário nem o niilismo de Dadá, mas apenas o motejo do humorista.

Apesar das solicitações paternas, o menino não ligava para o barro dócil, ou a terracota, que os pais the davam para divertir-se. Nunca teve gosto pela modelagem, iria reconhecê-lo cedo, no limiar da carreira. Deixava aos pais essas coisas ligeiras ou femininas, para entregar-se, como boa criança americana do começo deste século, à admiração pelos novos deuses da época: a máquina - o auto, o gramofone, o cinema. Aposto que não trocaria nenhuma estátua do mundo, nem obra do pai ou do avô, nem de Miguel Ângelo, por um daqueles automóveis delirantes, na sua insistência impressionista de parecer com o velho tílburi de então, e que passavam trepidando num barulho infernal, como prestes a arrebatar, sacudindo por soluções irresistíveis e incuráveis.

De sua meninice, entretanto, condescendeu o rapaz em deixar um auto-retrato que é uma revelação. É um desenho a creiom de 1907, em que se vê o garoto de serrote em punho, e rodeado de ferramentas viris, práticas, como torquês, puas, martelos, que-seieu. Este trabalho é, além disso, uma obra de perfeito modernismo. Hoje, pode-se dizer que foi o ponto inicial de sua carreira. E já é uma antecipação, uma sugestão misteriosa de sua futura evolução criadora. Aí estão os instrumentos mecânicos necessários ao trabalhador industrial. Ainda hoje usa alguns deles para seus objetos como os pais usavam o talha-frio, o buril para suas esculturas. O que atraía o jovem de então não eram os nobres instrumentos da arte caseira, mas ferramentas, simples ferramentas do ferreiro, do carpinteiro, do artesão enfim. De fato, oito anos depois desse retrato, entrava ele para o Instituto de Tecnologia. Sua carreira estava traçada: malgrado duas

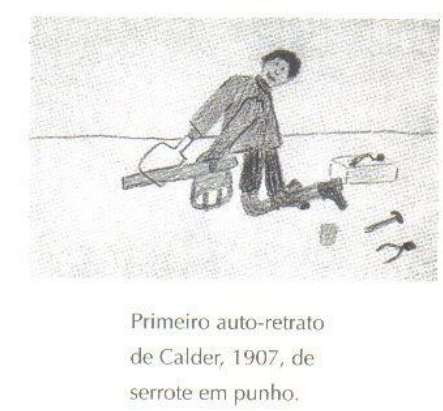


gerações de artistas por trás dele - ou por isso mesmo - o terceiro Calder seria engenheiro. Com efeito, ao concluir o curso tecnológico, empregava-se num escritório de engenheiro em Nova York.

A tara artística, entretanto, era pesada demais... e o aceno da musa de vez por outra surgia fugitivo do outro lado da rua... para desespero do jovem engenheiro, na sua mesa coberta de papéis cheios de cálculos, e atravessada de esquadrias, compassos etc.

De repente, o técnico tornou-se repórter de circo. Isso lhe foi como o abre-te-sésamo da caverna miraculosa da fantasia. Os bichos do circo o absorveram. A ménagerie era, todas as noites, a sua principal atração. Nunca já se olhou para bichos com maior encanto e surpresa. Tanto que nunca mais, mesmo nos momentos de suas criações mais abstratas, perdeu ele o interesse pelas formas vivas de animais. Sua obra de escultura com material mais ortodoxo, suas esculturas em madeira, por exemplo, são de formas de animais, com uma única exceção - a sua admirável figura humana, Uncomfortable Face (1928) - , e até mesmo alguns de seus trabalhos em metal. Essa fascinação pelas formas orgânicas de animais persiste por toda a obra até hoje (por exemplo, a escultura em madeira relativamente recente: $O$ monstro de maçã). Publicou mesmo em 1926 um pequeno livro: Animal Sketching. E ilustrou as fábulas de Esopo. ${ }^{50}$

O circo, porém, não lhe abriu a porta propriamente da arte, mas antes do país das maravilhas, isto é, da vida. A arte era então para ele como uma espécie de tara familiar, da qual não conseguia escapar. Mas o circo de cavalinhos foi o encantamento, o suco da própria vida. Ele se divertiu imensamente com o circo. E sem pensar em arte lhe veio a idéia gozada de fazer uns bichos que andassem, ou mexessem, como os do picadeiro. Fabricou uns cavalos, uns gatos, de corpo de cortiça, pernas e patas de arame articuladas, sobre rodas, algumas desiguais. Depois sistematizou mais alguns bichos de cabeça de arame, de pau e couro. Paris, já se sabe, virou logo o brinquedo em coisa transcendente, em arte, e alguns dos bichos articulados tiveram a honra de ser exibidos no Salão dos Humoristas.

Transformado em empresário, dono de uma ménagerie sui generis, Calder se viu arrastado a completá-la com uma troupe de artistas. E, quando menos esperava, viu-se com um circo em miniatura completo. Começou a dar funções no seu ateliê ou nos ateliês dos amigos. O fato é que dentro de pouco tempo o circo Calder criou fama em Montparnasse. Os grandes nomes das artes e da literatura vinham assistir ao circo, cujas funções se passavam à luz de uma ribalta que ele mesmo armou e ao som de um gramofone com manivela. Eminentes críticos de circo parisienses dignaram-se até escrever sobre suas funções. E Calder foi consagrado pela vanguarda artística de Paris como humorista. 


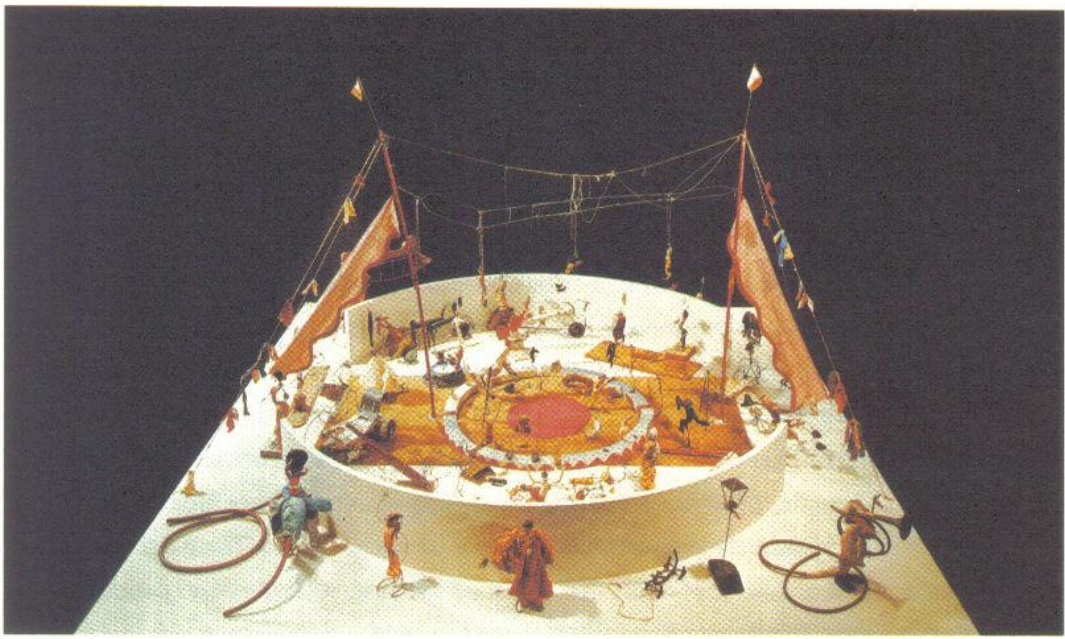

O Cirque Calder dos primeiros anos em Paris, 1926-1931.

\section{Abaixo: Fanni, a} dançarina-do-ventre 1926-31; Engolidor de espadas, 1926-31.

Diz Sweeney, o grande crítico americano, num admirável e luminoso estudo sobre Calder, que o circo insinuou em Calder a estética do inacabado, da suspensão e da surpresa. De fato, o que os artistas do circo Calder, gente e bichos, nos revelam é a incerteza, a imprecisão. Os bonecos se humanizam precisamente por essa incerteza, pelas falhas. Ninguém sabe se conseguirão ou não realizar o número arriscado: isso dá ao circo aquela atmosfera de ânsia e surpresa dos grandes momentos, quando os tambores rufam, e a respiração dos espectadores fica suspensa, diante do salto ou da proeza perigosa dos artistas de verdade. Nada como esses momentos do circo Calder para revelar, aliás, a puerilidade comovente dos circos reais.

O circo profissional se caracteriza pela precisão quase mecânica de seus artistas; o de Calder, pelos freqüentes fracassos de bonecos sem vida que, nos grandes momentos de sensação, nos revelam a miúdo a profunda e tocante inocuidade dos números sensacionais que fazem a glória do gênero. É uma paródia do circo de verdade, e está para o real como Père Ubu para Macbeth. Num espetáculo que exige acima de tudo a precisão, a destreza, a infalibilidade das coisas mecânicas em seres vivos, homens ou bichos, ele acentua, precisamente, as qualidades contrárias, essa insegurança e imperfeição que caracterizam os atos humanos, e que ele injeta nos seus artistas de picadeiro, nos bonecos e brinquedos inanimados, de arame, cortiça, couro, pano ou pau, desgraçados protagonistas de proezas impossíveis.
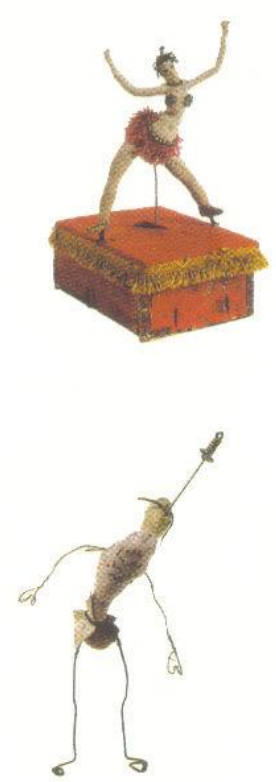


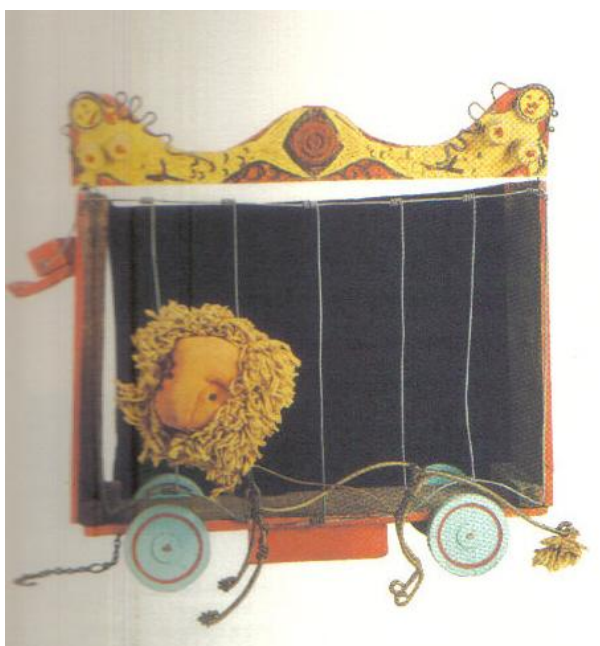

Esses bonecos se acendem por isso mesmo de um calor humano, comovente e cômico, pueril e ridículo, que nem sempre se encontra nos trapezistas convencidos, nos empertigados engolidores de fogo ou de espada, nos equilibristas de bigodes retorcidos, nos terríveis levantadores de peso, nos saltadores cheios de maneirismos, nossos irmãos de carne e osso, mas despidos de humor. Por serem menos eficientes, menos destros e articulados do que os artistas de verdade do picadeiro, exprimem os brinquedos de Calder uma humanidade mais comovente e profunda.

Entretanto, suas primeiras tentativas artísticas foram de pintura a óleo. Mas não o satisfizeram. E a tradição escultórica da família, forte demais, impeliu-o um dia a recorrer a uma estaca de cerca para se exprimir. Dela tirou sua primeira obra esculpida: The Flattest Cat.

A iniciação à escultura em Calder foi assim como uma volta de filho pródigo. Mas enquanto o pai gostava de fundir, o filho, marcado profundamente já pelo senso eminentemente moderno do funcional, desdenhava a modelagem, mostrando um respeito quase religioso, uma presciência da alma do material. Vejam-se nesse sentido suas obras em madeira, seu cavalo feito de caixa de charutos, seu Double Cat, que sai da ganga do material como se se tratasse de um baixo-relevo em que a forma total vai surgindo pouco a pouco do bloco inteiriço. Essas esculturas em madeira, como a admirável Uncomfortable Head, têm assim uma qualidade de escultura em pedra; nelas notase o mesmo processo paulatino de revelação da forma, que parece desabrochar pouco a pouco do bloco de matéria bruta. A madeira foi o meio pelo qual Calder desenvolveu sua profunda intuição dos materiais, da qualidade funcional destes. A qualidade porosa, plástica da madeira o seduz, e suas primeiras obras neste material não são mais do que a expressão de sua capacidade de tirar o maior partido de todas as sugestões que ela oferece, não só de tessitura como de forma.

Ainda brincando é que descobre as possibilidades de um novo material para experiência: $\mathrm{o}$ arame. Da cabeça de arame de certos brinquedos, ele passa a fazer figuras inteiras desse material inortodoxo. No arame, encontrava a oportunidade ao mesmo tempo para desenvolver, não no papel, mas no espaço, sua própria fascinação pelos segredos e hieróglifos do desenho e aprofundar o senso inato do humor. $\mathrm{O}$ arame é um material que por suas propriedades está nos limites extremos do campo específico da escultura.

De fato, o primeiro uso que fez dele foi para uma obra quase puramente linear, que se desenvolve toda num só plano como papel recortado - a sua Josephine Baker. O 
humorista do circo aprofunda a sua verve, e graças ao arame chega quase a uma nudez de caricatura. Consciente pela primeira vez de sua arte, o artista sente-se de posse dum novo meio de expressão, o desenho a arame no espaço. Seus primeiros trabalhos em arame têm ainda caráter de representação, de ilustração quase; na realidade, são caricaturas, gênero eminentemente gráfico. Nas obras posteriores, porém, nas cabeças de Ozenfant, Vogelgesang e outras, as linhas do contorno já tendem mais deliberadamente a organizar o próprio espaço vazio, dando à obra valor plástico estrutural mais acentuado. Os contornos dos planos já conseguem uma sugestão de volume. Agora só lhe falta a densidade, essa qualidade maciça que o arame não pode dar. Por isso mesmo, os escultores ortodoxos rejeitam essa pura arrumação de linhas no espaço, sugerindo planos e volumes. Falta-lhe o senso do tato, reclamava o pai escultor. Sim, faltavam-lhe essas relações de superfície, o jogo fascinante das modulações.

Graças ao novo material, porém, Calder obtém aquela transparência do volume que procuravam construtivistas e cubistas, ou artistas individuais, como Lipchitz. Aliás, era este, em 1927, o problema que se havia posto Lipchitz ao iniciar suas primeiras esculturas de tiras torcidas de bronze fundido, à procura de "coisas aéreas e transparentes que pudessem ser vistas de todos os lados simultaneamente". Brincando, alcançava Calder essa organização espacial do objeto.

Lipchitz, com suas esculturas abertas de tiras torcidas de bronze fundido, não conseguiu criar aquelas coisas aéreas e transparentes por que almejava. Sua tentativa de transcendentalização do cubismo pictórico pela escultura foi uma tentativa malograda. E seus objetos perderam em solidez estrutural, em acabado, e não ganharam em projeção espacial, sempre turvos nos seus contornos enovelados, abstratos mas informes. Os seus discípulos retardados de hoje em dia levaram a lógica interna daquele barroco macambúzio ao seu ponto morto, quando um certo quê de enigmático inerente à qualidade abstrata de seus objetos degenera em mera literatura, sem que os contornos se tornem mais límpidos ou o esfumado plástico menos aparente. É que os discípulos, menos avisados e originais, põem a nu o que no mestre era apenas recôndito: o profundo caráter decadente de sua obra.

Para problema semelhante, Calder, com um meio muito mais direto, sem recorrer ao artifício da fundição, nem violar a especificidade funcional do bronze, que não pode exprimir transparência ou qualidades lineares do torcido, recorreu ao arame; com este, sim, feito para torcer, construiu volumes transparentes, uma organização espacial aberta sem que isso tirasse à obra a clareza dos contornos ou a unidade espacial total.
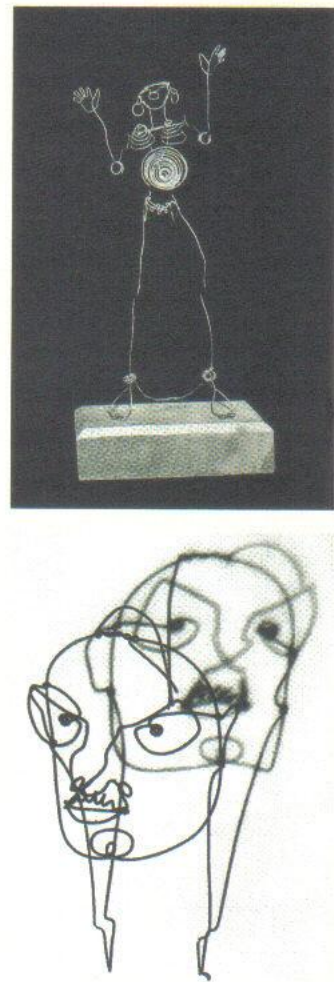


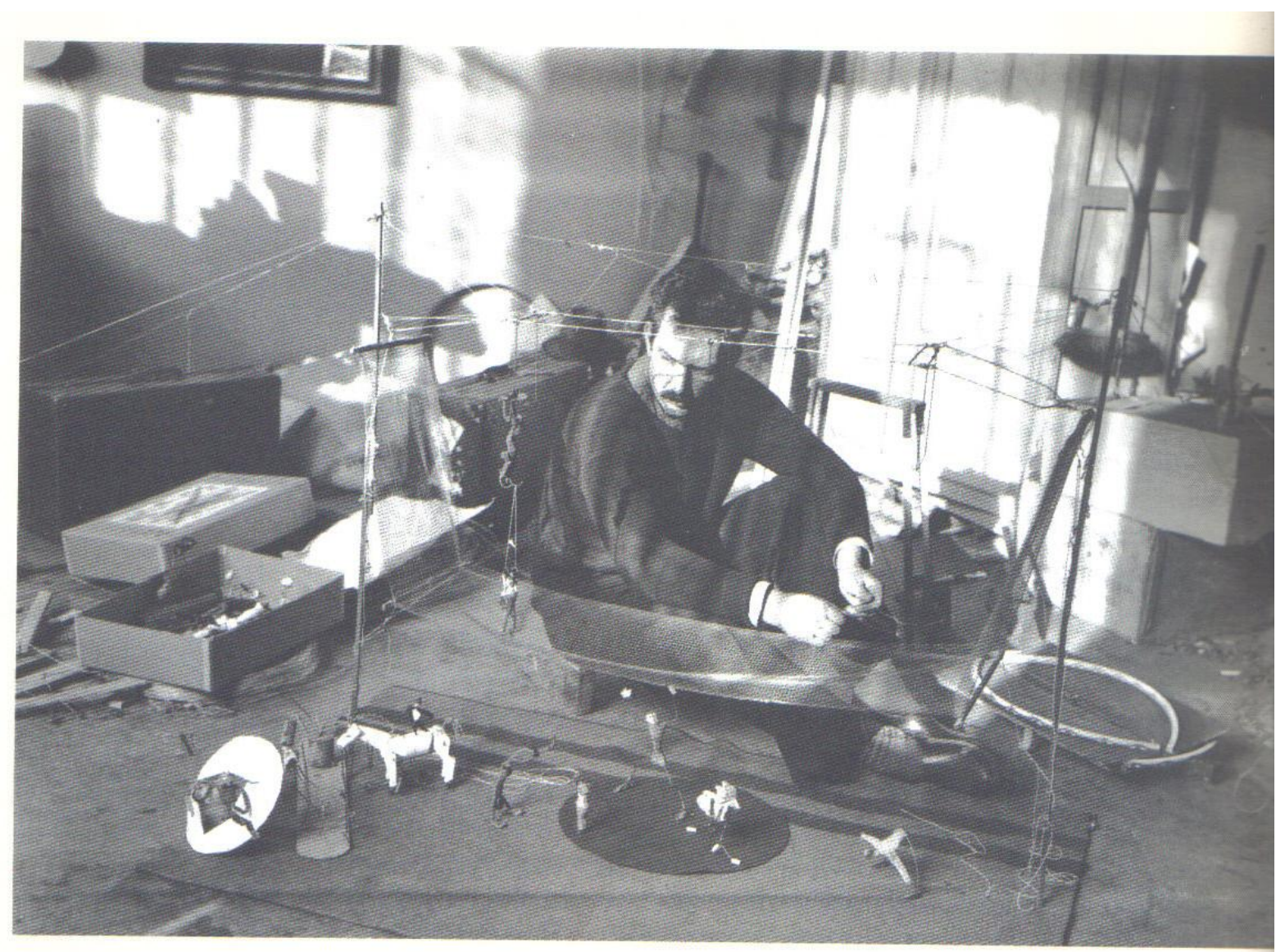

Cirque Calder, Paris, 1927.
O senso do linear em Calder dá-lhe talvez um certo parentesco com os artistas chineses. Na sua escultura em arame consegue sugerir o volume, apenas pelo vazio que define por contornos e linhas; da mesma forma os chineses para a sua organização espacial não recorrem a sombras ou ilusão de relevo e de sólido mas apenas a linhas e contornos, idiotismos quase da arte chinesa. A concepção do desenho dos velhos mestres da China se baseia não na simetria mas no inacabado e no estímulo espacial. Calder tem pelo modelado e pela modelagem, as sombras e gradações de valores e relevo, um desdém que compartilha com os pintores chineses. Salvo nas obras em madeira, faltathe o senso do tato, da camada superior da matéria, tão absorvido vive pelo movimento que dá a linha e os planos que dão os contornos, traço de seu linearismo profundo. Mas por outro lado, com sua atração irresistível pelo mundo das formas abstratas puras - esse andaime de formas virtuais constituindo como que a própria estrutura abs- 
trata do universo, e que revela no artista que a sente um traço indelével de classicismo - Calder é o oposto dos artistas chineses. Padece desse perene encantamento formal puro, desconhecido daqueles artistas embebidos de subjetivismo, mas tão assinalado nas grandes manifestações da arte ocidental.

O caráter caligráfico das esculturas em arame é tão acentuado que se compreende que tenham tido tanto êxito com os pintores e tão pouco com os escultores. Assim, por exemplo, enquanto pintores como Pascin, Miró e outros sentem o encanto dessas figuras em arame, desses desenhos no espaço, outros, escultores, inclusive o pai, não escondem o pouco entusiasmo por essa qualidade "fria", sem massa, hostil à escultura, que distingue $o$ arame.

Apesar de sua profunda compreensão do material, que the é a maior qualidade escultórica, Calder não pensa como escultor, mas como pintor ou desenhista. O senso predominante do ritmo linear afasta-o dos problemas absorventes do volume maciço. Por isso mesmo, à

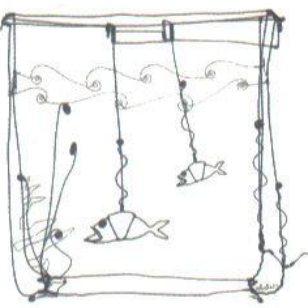
parte do esboço de suas cabeças de arame, ele não faz estátuas. Foi provavelmente esta absorção pelo ritmo que o fez procurar introduzir mais tarde em sua obra um novo elemento, o movimento real, e não a sua representação. $\mathrm{O}$ desenvolvimento aqui não segue tampouco a linha natural da evolução do escultor.

Calhou, em 1929, que deparasse Calder com uma coleção de pássaros mecânicos articulados procedentes do século хуші. Encantou-o aquilo. Terá vindo daí a idéia do ritmo cinético? O fato é que nesse mesmo ano construía ele uma espécie de aquário com um peixe de arame, movido por uma pequena manivela. Foi a este brinquedo articulado que Sweeney chamou de "caixinha de música com ritmos visuais". Sem que desse maior importância à sua "caixinha", 0 artista sente-se, entretanto, de posse dela, num estado de completa disponibilidade, como uma vela tensa à espera dos grandes ventos marinhos. Foi nesse estado de espírito que recebeu o "choque" de Mondrian. Ele conta, de fato, como, ao contemplar, pela primeira ver, aquela ordem, aquela calma espacial, aquele purismo severo que era o ateliê do artista holandês, reprodução exata de sua própria pintura, um mundo novo se revelou à sua imaginação e lhe abriu a cortina para os horizontes ideais que procurava sem saber: o mundo da pura forma abstrata. (Note-se como suas influências decisivas vêm sempre de pintores e não de escultores.) Sua obra pode-se então dividir em pré e pós-Mondrian.
Aquário com peixinhos dourados, 1929

O ateliê de Mondrian na rue Départ, em Paris.

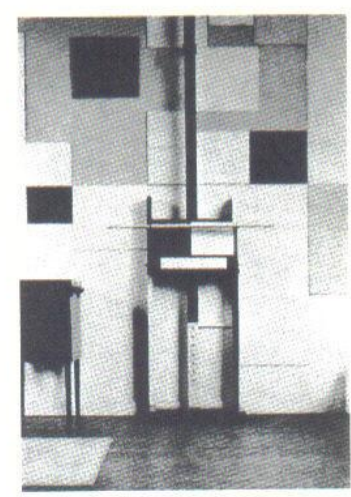



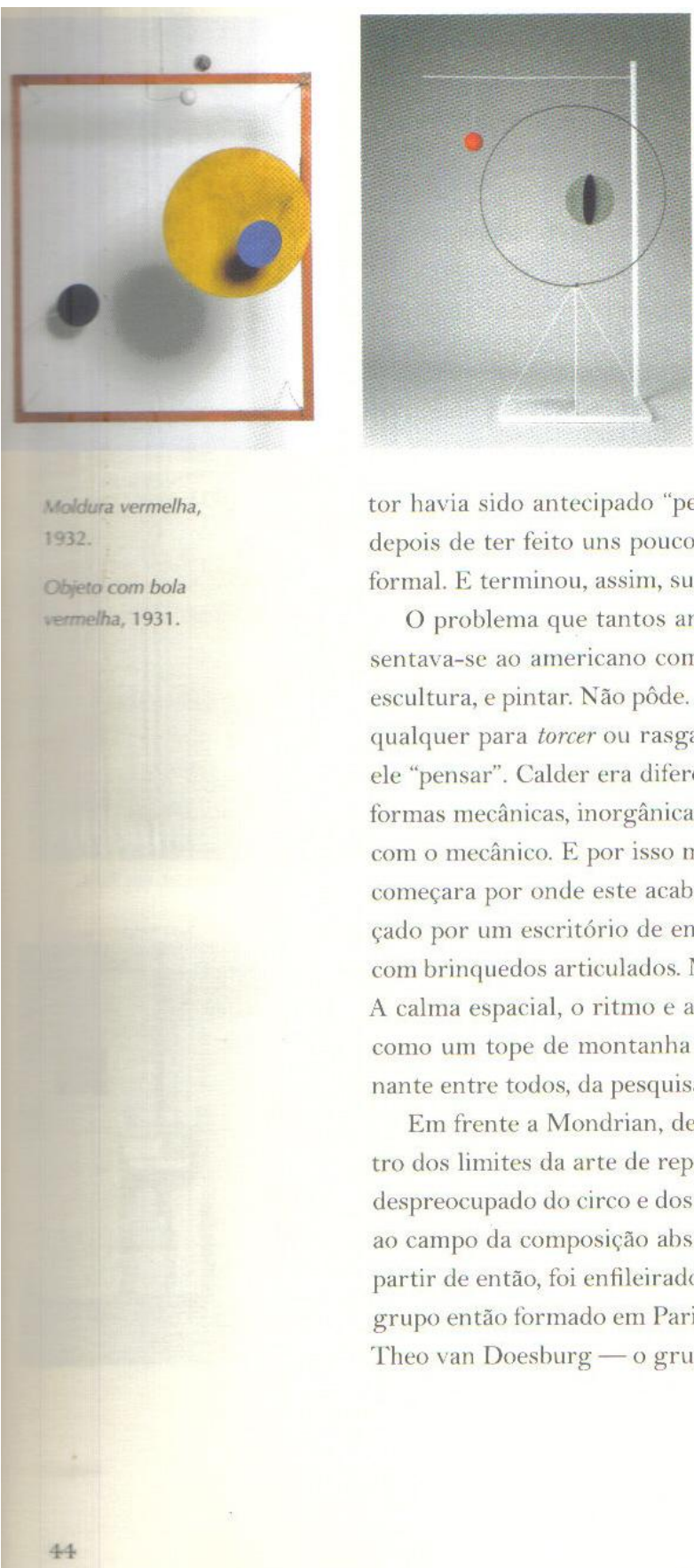

Foi para casa abalado, quis ser pintor. Por que quis pintar? Façamos aqui um paralelo significativo. Já o saudoso escultor francês Gaudier, ainda em tempos que hoje nos parecem pré-históricos — durante a Primeira Guerra Mundial — chegava à conclusão de que a abstração formal absoluta era mais própria à pintura do que à escultura. Para Gaudier, essa abstração implicava "uma considerável complexidade de formas", e isso "seria prejudicial ao senso escultural fundamentalmente simples". Ao malogrado artista parecia que a pintura tinha ainda "todo o campo das formas inorgânicas a explorar", ao passo que o escultor havia sido antecipado "pelos desenhistas do maquinismo moderno". Com efeito, depois de ter feito uns poucos brinquedos inorgânicos, renunciava à pura abstração formal. E terminou, assim, sua aventura abstracionista em escultura.

O problema que tantos anos antes já havia atormentado o escultor francês apresentava-se ao americano com toda a sua complexidade. Calder tentou abandonar a escultura, e pintar. Não pôde. E, como ele mesmo contou, "fio de arame, ou outra coisa qualquer para torcer ou rasgar ou dobrar" era-lhe um material mais dócil para com ele "pensar". Calder era diferente de Gaudier. Era um mecânico, um técnico afeito às formas mecânicas, inorgânicas, da engenharia moderna. Aqui, o escultor se confundia com o mecânico. E por isso mesmo ele fizera o caminho inverso ao do colega francês, começara por onde este acabara. Chegara à forma abstrata pura depois de ter começado por um escritório de engenheiro, e passado por uma longa fase de experiência com brinquedos articulados. Mas esta impotência diante da pintura era uma revelação. A calma espacial, o ritmo e a cor do purismo mondriânico brilhavam aos seus olhos como um tope de montanha inacessível. O artista estava diante do problema, fascinante entre todos, da pesquisa da pura forma - da pura criação.

Em frente a Mondrian, desapareceu o ilustrador, o desenhista, o artista preso dentro dos limites da arte de representação, de assunto; desapareceu mesmo o humorista despreocupado do circo e dos bonecos. Da representação direta ou sugestiva, ele passa ao campo da composição abstrata. É uma fase decisiva na curva da arte de Calder. A partir de então, foi enfileirado entre os abstracionistas. Anuncia mesmo sua adesão ao grupo então formado em Paris pelos admiradores de Mondrian, com Arp, Jean Hélion, Theo van Doesburg - o grupo Abstraction-Création. 
Numa exposição que então fez em Paris (em 1936), abjurou seus retratos a arame. Paris estranha a metamorfose do artista, que já havia classificado de humorista, em purista austero. E muitos não escondem a sua decep̧̧ão.

Realmente, em contraste com a fase anterior, de alegria despreocupada mas interessada, agora Calder faz figuras geométricas, esferas, esferóides, círculos e discos, aos quais define, com a precisão de engenheiro, como "volumes, vetores e densidades". Mas desta vez são pintados em cores primárias, ou simples, vivas, em azul, em vermelho, em negro. Desses objetos, ele mesmo diz que são "simples coisas, arrumadas numa prancha contra uma parede, e algumas delas", assegura, "eram, sob certos aspectos, tão plásticas quanto tudo que já havia feito". Foi a essas esculturas abstratas, estáveis, imóveis, que Arp deu o nome de estábiles. Com estes vetores, a cor faz a sua entrada, traindo a fascinação do artista pela pintura, como anteriormente o arame revelara a sua aptidão de desenhista.

Abandonando de vez os problemas próprios à escultura, como os do aprofundamento do material e o tridimensionalismo, as massas compactas e seus contrastes de sombra e luz, ele toma por um caminho ainda não batido, por assim dizer fora do campo específico das artes plásticas. Fascina-o o problema da projeção das formas no espaço. A idéia lhe veio de projetar no espaço, de fazer girar aqueles painéis imaculados e estáticos mas fortemente coloridos do ateliê de Mondrian. O mestre holandês horrorizou-se, naturalmente, com a idéia. Mas esta venceu, pela própria lei mecânica que define o movimento como inseparável do repouso. Uma vez criados os estábiles, era forçoso que se seguissem os móbiles.

O escultor, em geral, sente o apelo do movimento mais intensamente do que o pintor. A escultura é, entre as artes do espaço, nas quais nada se move, e as do tempo, nas quais nada se conserva exatamente como era no instante anterior, o elemento de transição. Como lembra um teórico eminente, as estátuas não se movem, mas nós podemos nos mover em redor delas. E este nosso movimento é "um substituto prático para o fluir objetivo no tempo", característico da música. Cedo chegando aos confins extremos da área específica da escultura, Calder tenta resolutamente transpor esses limites para atingir ao fluir no tempo, privilégio da arte do som.

Cabe notar que Calder, já no limiar da carreira, usara do movimento; mas, então, apenas com o propósito de alcançar uma simples impressão naturalística: dar vida a bonecos e brinquedos. Aquela era, por assim dizer, uma fase pré-artística, que quase não se distinguia ainda das preocupações profissionais do engenheiro. Não se sabe a linha divisória entre onde acaba a mecânica e a arte começa. Mas pouco

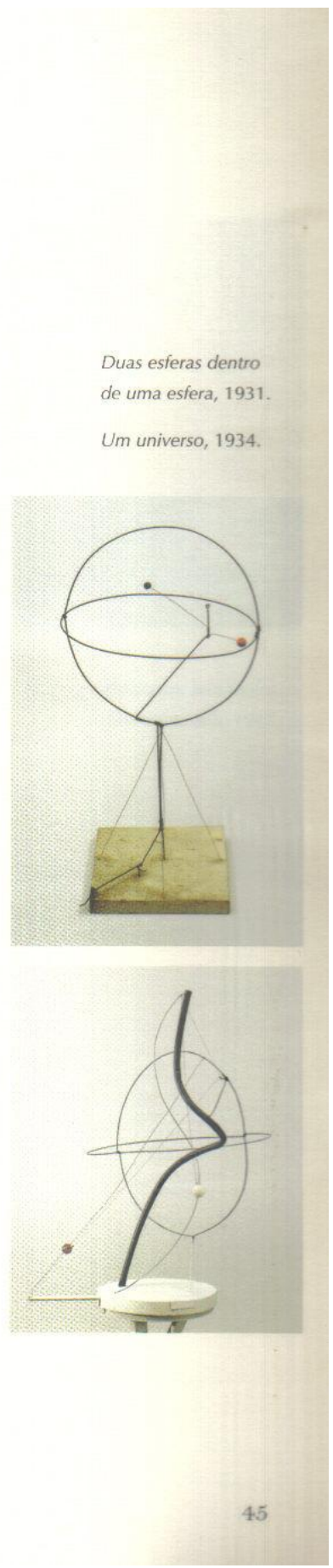


a pouco essa atração pelo movimento se torna simplesmente um dos seus grandes problemas estéticos.

Assim, já trazendo atrás de si longa experiência dos brinquedos animados, a incorporação do movimento real na sua escultura se originava numa concepção mais alta e transcendente do que quando pôs a mover, por meio de rodas ou manivelas, seus bonecos de circo ou seu aquário-gaiola com peixinho de arame movido a manivela. Então ainda visava mais ao brinquedo do que a qualquer outra coisa; queria fazer peixe nadar, boneco mexer ou bicho pular. Era o brinquedo mecânico que o interessava. Agora, porém, depois de Mondrian, a idéia da introdução do movimento real apresenta-se para ele como um novo elemento essencialmente plástico. Daí nascem os móbiles; primeiro, movidos à manivela que aciona um ou dois movimentos simples. Depois, acrescenta um mecanismo mais complexo que a simples manivela: um motor. Foi a solução que encontrou para chegar à organização de movimentos contrastantes e relações variáveis de formas no espaço, que é o problema dos móbiles. Era enfim a realização viva, espacial, dos painéis do estúdio de Mondrian limitados às duas dimensões do plano. Compõe movimentos armados sobre uma base estrutural; visa a convencer-nos pelo ritmo. Por um dispositivo mecânico, move agora formas geométricas no espaço. Mas os objetos se movem dentro dum quadro, num ritmo predeterminado. A sua escultura de arame, a princípio ainda limitada a um só plano, acaba por sugerir volumes transparentes, sugerir, por exemplo, gestos de dançarinos, volumes no espaço. Seus painéis motorizados têm no começo um franco caráter de bailado, dotados de uma espécie de proscênio sobre o qual erguem-se formas em madeira. O problema fundamental dos móbiles, essa busca das relações espaciais dos objetos, equivale quase à procura metafísica da realidade não-contingencial das coisas. A essencialidade das formas desencarnadas de qualquer convenção, ou função externa. Para mover-se nesse mundo das formas puras mais facilmente, recorre a sugestões e motivos não-orgânicos. Assim, evita qualquer sugestão naturalista ou realista e mais facilmente achará o material com que construir aquele próprio mundo, em que só o movimento cósmico, o movimento em abstrato, é senhor absoluto.

$\mathrm{O}$ abstracionismo de Calder, entretanto, não se fez apenas do purismo austero de Mondrian. Dificilmente podia agüentar-se na atmosfera rarefeita quase, de tão pura, daquela pintura; seu humor, sua alegria perpétua não encontravam alimento com que nutrir-se na arte desnuda, quase franciscana, de Mondrian. Já quando decidiu explorar o campo tecnológico dos "vetores, dos volumes e densidades", que passou a exprimir servindo-se do mesmo material familiar com que produziu suas figuras em arame, fê-lo 
deliberadamente para manter a pureza plástica que tanto o seduziu nos quadros e painéis do artista holandês. Suas manifestações de novo abstracionista não foram como pintor, mas como aramista austero, que rejeita o humorista de Josephine Baker, o caricaturista de Helen Wills, o escultor bonachão das cabeças já mais estruturadas de Vogelgesang e outros; e, ainda mais decisivamente, o longínquo artesão dos bonecos de circo.

A fase "vetorial" foi apenas uma transição, enquanto se preparava para conciliar o purismo com a vida. Miró foi o veículo dessa conciliação. O curioso é que quando conheceu Miró não o compreendeu; e o viu antes de conhecer Mondrian. Só depois de passada a fase do mondrianismo fervoroso é que pôde penetrar a arte do pintor espanhol. E então, só então, recobrava, graças a Deus, o humor, quase recalcado no ambiente depurado, quase místico, do abstracionismo. Seu humor casava-se perfeitamente com a alegria gritante da pintura de Miró.

Ao descobrir Mondrian, resolveu sacrificar o humor à pintura. Não o conseguindo, carregou-a, ao contrário, ao campo dos vetores, transplantando o ateliê, imutável e repousante, daquele, para grandes painéis motorizados, mas tocados desta vez das cores e alegrias que palpitam nos quadros de Miró. De modo que os grandes painéis são como que uma síntese, ou o resultado da fusão, na sua sensibilidade, do purismo do mestre holandês e da vibração jovial do mestre catalão. Desta forma coordenou suas novas conviç̧ões abstracionistas, introduzindo, aqui, um elemento humano muitas vezes ausente entre abstracionistas absolutos - o humor, e com este, pouco depois, alargando o reino de seus motivos então limitado ao mundo geométrico, assimilou as formas orgânicas que pululam nas telas de Miró.

Essas formas geométricas, que se movem no espaço, não tardaram assim em desintegrar-se, ao contato dos micróbios e bacilos mirovianos e da sugestão de novos materiais (vidro, cordão, rodóide, alumínio etc.). Perdendo a rigidez austera, cedem à sugestão desses novos materiais encontrados e à sedução das manifestações dissolutas da natureza orgânica. É quando, descobrindo seus móbiles de ritmo livre, transforma o movimento enquadrado que fornece o motor em movimento indeterminado, em elemento musical - uma sucessão no espaço e no tempo, como uma escala; arquitetura de acordes, que traçam no espaço um puro arabesco musical, de natureza pois abstrata e formal.

Nos móbiles, com suas pétalas e folhas, fios ou hastes, espinhos ou galhos, rodas ou esferas, enquadrados espacialmente por contornos sempre claros, é à nossa imaginação que acenam essas figuras geométricas ou sugestões de linhas e padrões em repouso; pois, ao saírem do estado de repouso, enchem-se então de novas formas, ideais ou virtuais. É uma arte, a sua, que está a serviço ativo da imaginação. Se esta não sopra sobre

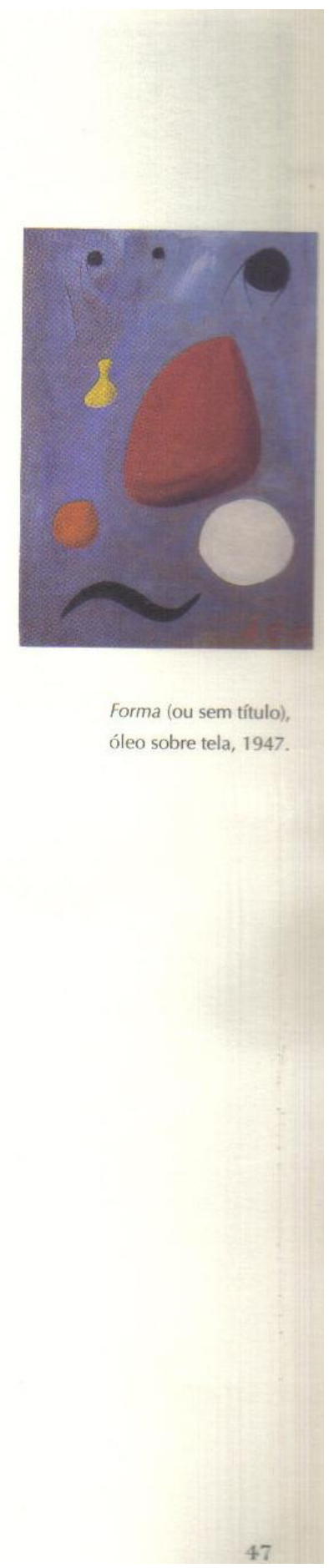



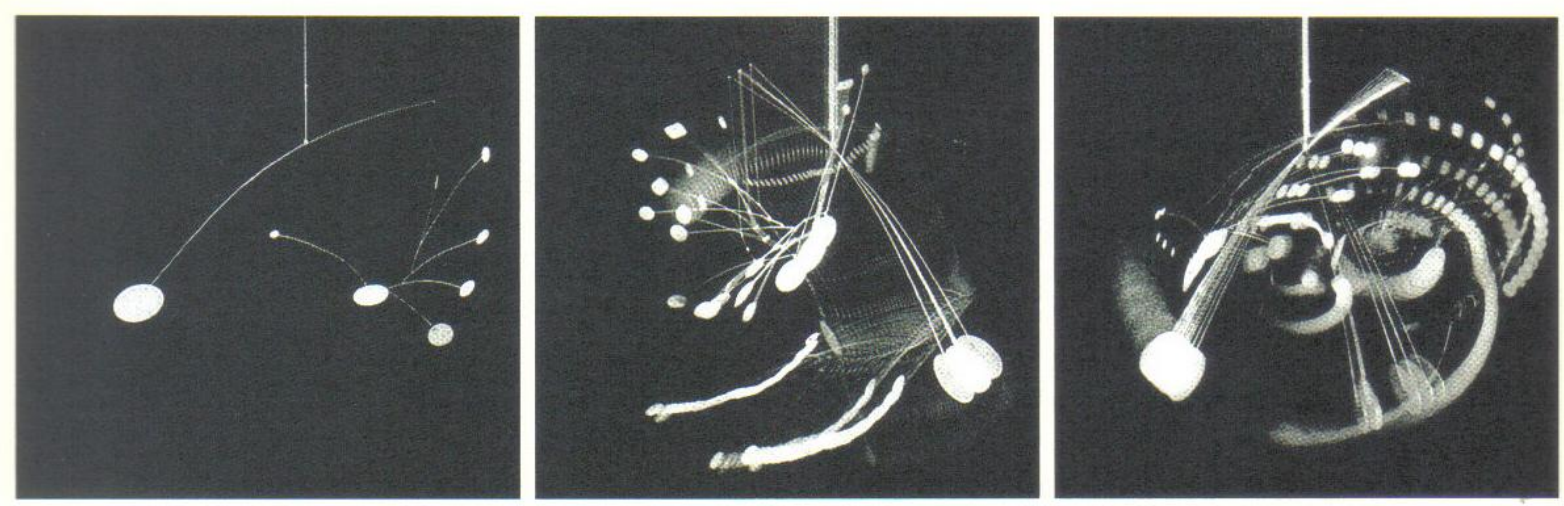

seus móbiles, seus estábiles, suas constelações, a obra não se ilumina, não palpita de vida, permanece quieta, parada, dormindo o sono indecifrável das coisas inanimadas e sem nexo. Os seus objetos, pelo seu próprio caráter preciso, formal, mas indefinível em termos convencionais, são um convite insistente e, por vezes, para certos observadores, irritante, ao trabalhos, à cooperação da imaginação formal.

Apesar do profundo desinteresse, da gratuidade plástica, do purismo, é a sua arte, entretanto, intimamente integrada com a vida. Realmente, para Calder, a arte não é uma profissão, nem tampouco uma paixão ou uma mania. É simplesmente a sua maneira natural de viver.

Diferente dos outros objetos artísticos, os de Calder não sofrem desse não-metoque que caracteriza aqueles. Na sua exposição no Museu de Arte Moderna em Nova York, a gente se espantava de ver a falta de respeito, a falta de tabu que ali reinava, pois qualquer um podia chegar e tocá-los, mexer, bulir e até empurrá-los com o pé. Sobretudo os grandes móbiles a movimento livre. A propósito desse caráter prosaico, nãoartístico dos objetos, com especialidade dos modestos móbiles a cordão, Ben Nicholson, o escultor abstracionista inglês, conta-nos uma experiência convincente.

A primeira vez que via um desses móbiles a vento menos pretensiosos, um desses que um crítico formalista chamou desdenhosamente de "decoração de arame, com pequenas bolas penduradas baloiçando do teto", "estranha espécie de moda nada tendo a ver com arte", decidiu Ben Nicholson levá-lo emprestado para casa, em Paris. Ao sopro da brisa, sob o reflexo das águas do Sena faiscando lá fora, à luz de uma lâmpada elétrica, girava suavemente o móbile que ele havia pendurado do teto de sua 

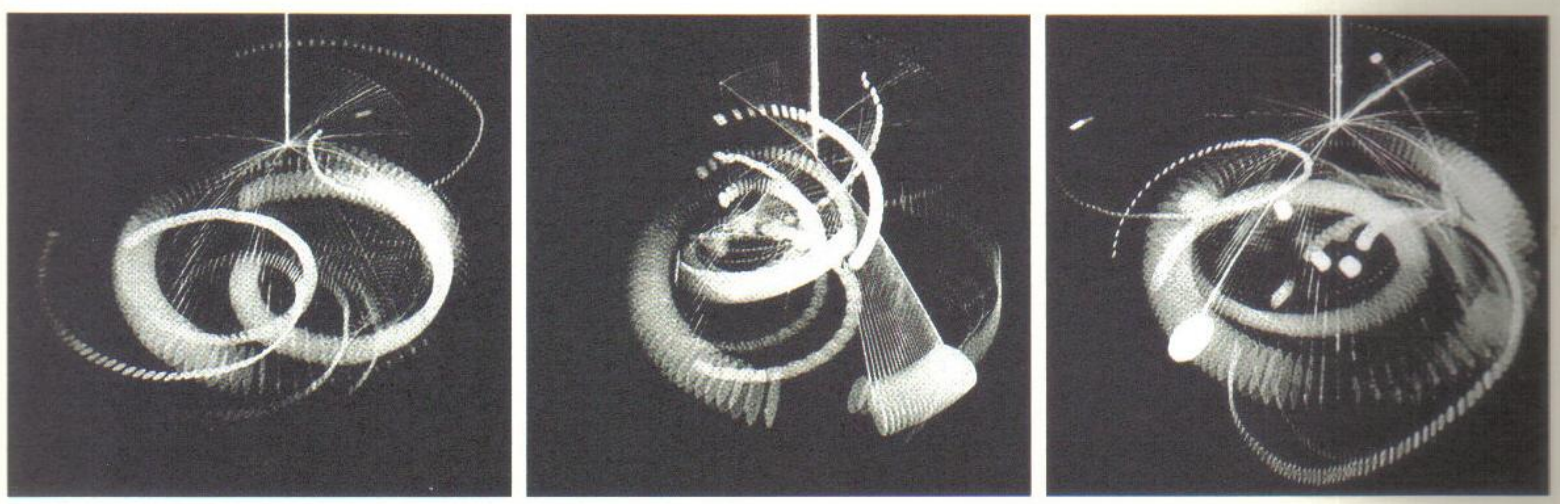

sala branca, em frente a uma janela que dava para o rio. O objeto animou-se, as bolas - uma negra, seis brancas e uma escarlate - que pendiam na ponta dos cordões

Móbile em movimento, 1936 evoluíam para um lado e para o outro, suas sombras casavam-se umas às outras, de encontro às paredes brancas da sala; os movimentos reais imprevisíveis se desenhavam num intercâmbio constante de luz, de cores e sombras. $\mathrm{O}$ artista inglês embevecido sentia que aquilo tinha vida, como o tinham o rumor da cidade e o rio que corria lá fora. Podia não ser uma obra de arte como muita gente pensa que deve ser uma obra de arte, engaiolada num quadro, numa moldura dourada, ou petrificada sobre um pedestal nalgum dos nossos mausoléus de colunas de mármore. Mas — arrematava, concludente e convencido - tinha vida, e essa qualidade não era para ele um mau qualificativo para uma obra de arte.

Ben Nicholson tinha razão. Só o que é criação tem esse toque de vida. Arte viril, arte não-convencional, não só na forma, na sua estrutura plástica, ou no uso dos materiais empregados; mas até mesmo na maneira de tratá-la, de lidar fisicamente com seus objetos. Ela não usa coturnos nem clâmides gregas nem é coroada de louros. É despida do esnobismo empertigado, cacete e cerimonioso que envolve tão freqüentemente a chamada grande arte dos museus e academias. É bonachona, ri-se de si mesma e quase nunca se desprende de certo dadaísmo larvado.

Não teme tampouco o contato direto do povo, ou as intempéries do ar livre, nem o barulho desrespeitoso dos mafuás. Conquista tanto o público bestalhão das feiras de amostra como o requintado esnobe que tem "horror à canalha". Nesse sentido assemelha-se à arte de Carlitos. 
A famosa Fonte de mercúrio que construiu para o pavilhão espanhol da Feira Internacional de Paris em 1937 foi o triunfo ali dessas qualidades. O público logo foi conquistado por aquele brinquedo que levava o mercúrio da mina de Almadén, na Espanha, então atacada pelos fascistas de Franco, ao alto de uma haste enorme e ereta para que de lá caísse depois sobre uma bacia circular, cheia de mercúrio, e tornasse a subir. Do mesmo modo o foram os estetas parisienses que se embelecaram pelo jogo fascinante do movimento plástico e musical ascendente-descendente, de relações formais que se desenvolviam no espaço. Nesta obra o engenheiro e o artista se fundiam numa harmonia perfeita. A funcionalidade evidente da obra se enquadrava admiravelmente no jogo puramente plástico de seus movimentos e de seus planos.

Esta é uma arte, pois, que não se separa da vida e, se acontece, também não se recusa a servir a outra, tende a impregnar com sua sedução o ambiente da vida moderna; e resiste, galharda, aos iluminados espaços do ar livre, nos livrando das estátuas indefectíveis das praças e jardins públicos, de homens a cavalo, ou de barba ou de espada, quando não de fraque ou de camisolão. Mas pode povoar essas praças e esses jardins de coisas nunca vistas, de sugestões de mundos e bichos desconhecidos, de fábulas novas, de sonhos, de imaginações e silêncios revivificantes... que se mistura, para dar realce e beleza, às atividades industriais da vida moderna - como na Fonte de mercúrio; que pode mesmo substituir, ou ainda poetizar, funções que imemorialmente vêm fazendo o encanto de meninos e adultos, como o boneco e o circo. Em seus painéis móveis, a grande Martha Graham reconhecia possibilidades dramáticas bastantes para usar de alguns deles, ampliados, para servir de "interlúdios plásticos" durante os espetáculos de seu corpo de baile. ${ }^{51} \mathrm{E}$ sua bonomia é tanta, e também sua virtualidade plástica, que pode condescender, sem que com isso se degrade, mas antes na vida cotidiana se integre para purificá-la do vulgar e do feito, a servir até de distintivo para estabelecimentos comerciais.

Seus estábiles e móbiles, seus objetos de aço ou arame, cordão ou alumínio, pau ou caco de vidro, nos evocam motivos de remotas eras geológicas ou de presságios de coisas ainda por existir, nos bracejamentos e tlin-tlins de alegria com que se agitam, ou nas sombras que projetam. Dir-se-ia que captam como antenas imagens que jazessem até hoje no ar, despercebidas e inexploradas. É uma arte democrática porque pode ser feita de qualquer troço, cabe em qualquer lugar, a serviço de qualquer condição, nobre, rara ou usual; e serve para revitalizar a alegria e o senso da harmonia, ora embotado, dos homens. Tende a transformar a vida de todos os dias e o ambiente, informe e feio, grosseiro e triste, em que vegetam as grandes massas populares embrutecidas, num 
meio dignificado pela beleza das coisas ordinárias e circunjacentes, e capaz de infundir nobreza à própria plebe.

Não era em vão que Arp proclamava, já há quase trinta anos, para a arte abstrata — a arte concreta, como ele preferia chamá-la —, a ambição de transformar o mundo. Desinteressada tal como é - tão longe de quaisquer fins de propaganda! - , a arte de Calder, no entanto, vai exercendo uma silenciosa ação de catálise sobre a vulgaridade generalizada e agressiva de nossa época.

Se há um artista, em verdade, que está próximo do ideal da arte do futuro, dessa sociedade ideal em que a arte seria confundida com as atividades da rotina diária, e a prática cotidiana de viver - esse artista é Alexander Calder.

[Correio da Manhã, Rio de Janeiro, 10 e 17.12.1944; recolhido in Pedrosa, Modernidade cá e lá, org. de Otília Arantes. São Paulo: Edusp, 2000, pp. 51-66.] 
ANEXO N- Reprodução Crítica de Mário Pedrosa: Tensão e coesão na obra de Calder In:: SARAIVA, Roberta (org.). Calder no Brasil: crônica de uma amizade. São Paulo: Cosac Naify/ Pinacoteca do Estado, 2006.pp 124-136.

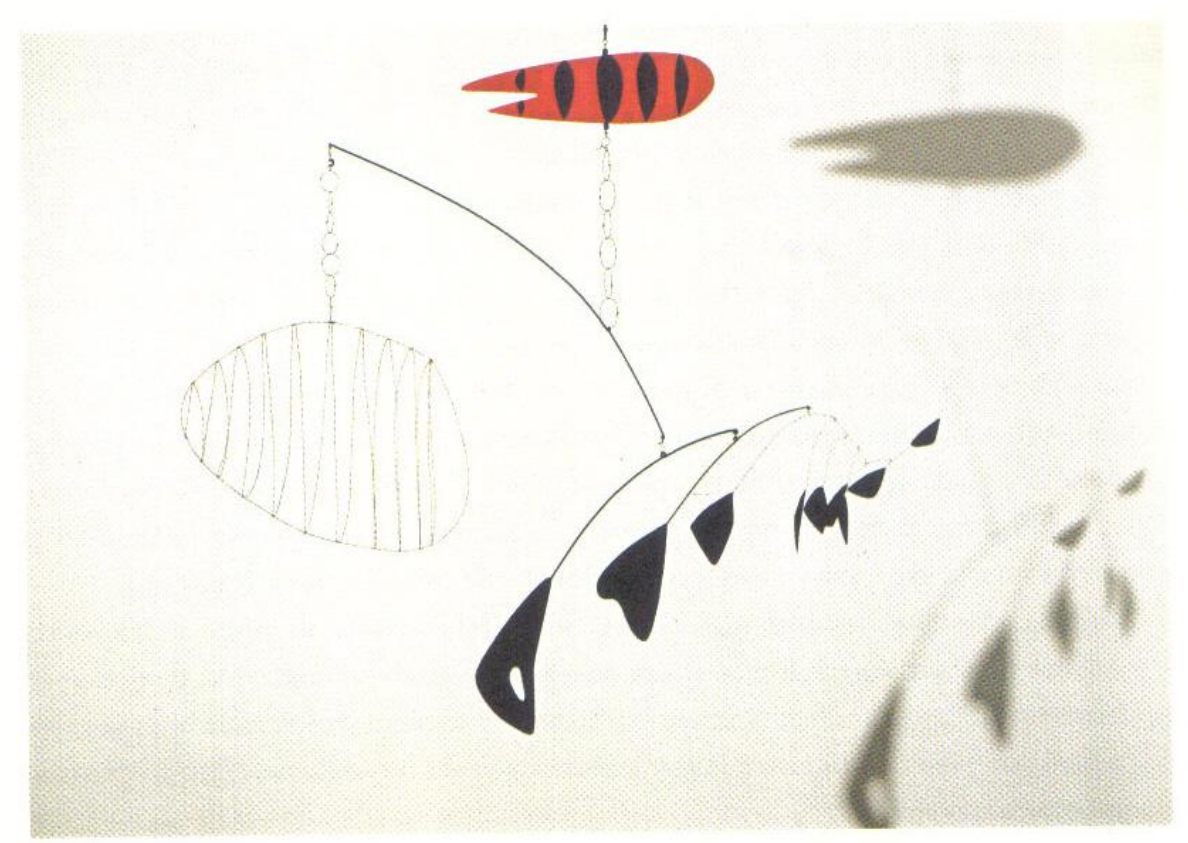

Tensão e coesão na obra de Calder

\author{
Mário Pedrosa
}

Os escultores modernos, desde Brancusi, cansados evidentemente do narcisismo de gregos e italianos da Renascença, recusaram-se afinal a continuar endeusando o corpo humano. Os deuses, em conseqüência, desumanizados, desencarnaram, desertando a terra.

Retinem ainda aos ouvidos modernos os versos de Apollinaire:

\footnotetext{
A la fin tu es las de ce monde ancien...

Bergère ô Tour Eiffel...
}

Depois deles, no início do cubismo, Delaunay introduziu a nova Pastora, de ferro, das margens do Sena, na pintura. Sua beleza era enfim proclamada, sem acanhamento, por gregos e troianos, engenheiros e poetas, pintores e turistas anglo-americanos. 
A promoção da Torre Eiffel a obra de arte constitui uma data na história artística da humanidade.

A escultura desistia de ter por função dar corpo de homem a deuses e abstrações mitológicas ou divinizar homens de carne e osso. As praças públicas quase se despovoaram: o censo deve ter revelado sensível baixa no nascimento das estátuas. Não fosse o mercado extraordinário e inesperado criado pelos diretores da época, quem sabe não teria parado a produção dessas obras? Ao menos para isso serviram... Os produtores dessa escultura de apoteose deveriam ser gratos a todos esses Césares sedentos de glorificação...

Em oposição ao realismo visual que se prolongou ininterruptamente desde a Renascença, os novos escultores descobriram uma espécie diferente de realismo, um realismo que já se chamou de "mental", e é o dos povos primitivos, ou se revela na arte romanesca, por exemplo. Eles, como os selvagens, passaram a ver com o espírito de preferência a ver com os olhos.

Em busca de outros temas de inspiração - outras formas -, esses escultores desprezaram não só os eternos problemas do volume maciço como os materiais de trabalho tradicionais desde Donatello e Miguel Ângelo. Ou quando daqueles se preocuparam ou destes fizeram uso, foi para servir a outros fins. Muitos viraram-se então para um novo mito, essencialmente moderno - a máquina; outros, para dentro de si mesmos; e outros, enfim, nem para uma nem para outra coisa, mas para a natureza, o universo.

Já os artistas chineses taoístas consideravam o princípio da simetria (tão pronunciado na arte de estilização de Bizâncio) como derivado da contemplação da forma humana. A partir da Renascença, entretanto, época do apogeu do desenho baseado nesta forma, a mobilidade, a fixidez formal que triunfou no Ocidente através da arte bizantina veio se desintegrando paulatinamente. A curva histórica, desde então até hoje, foi no sentido de uma libertação crescente do desenho, que ganha em ritmos livres, em flexibilidade, o que perde em fixidez formalística. E são esses elementos que vão contribuindo cada vez mais decisivamente para a expressão plástica moderna.

Nesse processo, tende o desenho, à medida que nos aproximamos da época moderna, a mostrar afinidades de mais a mais acentuadas, não só com as artes dos povos primitivos como com a arte requintada e formal dos chineses - tão oposta ao hieratismo bizantino, e tão livre! Realmente, estes últimos, para evitar a simetria, mortal à alma do desenho, deram as costas à forma humana. E descobriram então a árvore, que conjuga a assimetria dos galhos com o equilíbrio do conjunto. Assim, encontraram o princípio do "equilíbrio assimétrico". 
Abandonando qualquer sugestão do corpo humano, e aproximando-se do princípio chinês do balanceamento assimétrico, Calder vê também na árvore, no vegetal, uma das fontes mais ricas de inspiração para a invenção de seus objetos; encontra aí sugestões para novas formas muito mais fecundas e variadas do que na figura humana. Entretanto, sem o simbolismo e o idealismo taoísta, que vê na árvore a fonte única e sagrada da assimetria rítmica, ele pode tirar inspiração de tudo o que se traduza num sistema de planos e linhas, e não volumes plásticos ou maciços — base da estatuária clássica.

Massas, ele as procura antes no campo industrial, na máquina - êmbolos, cilindros, prismas -, nos sólidos geométricos, enfim. A árvore, por causa de seu assimetrismo equilibrado, lhe dá sugestões lineares, um automatismo aparente de movimentos, uma mobilidade imprescindível; do mesmo modo, a carcaça de bichos ou do homem, com sua estrutura que se assemelha à da árvore (espinhos, vértebras, esqueletos), por causa da arrumação dos planos e precisão de contornos.

De fato, se o mineral nos interessa sobretudo pela matéria rica de sua infra-estrutura, de suas superfícies, sua força de atração sobre os homens é limitada. O vegetal, porém, exerce uma fascinação inexplicável, e talvez o segredo desta esteja na sua emoção retida, o trêmulo e sóbrio balbuciar dos galhos ou das pétalas frementes. Sua fragilidade constantemente exposta, mas continuamente palpitante e presente e corajosa e afirmativa, eis a grande lição do vegetal ao homem, à alma humana.

$\mathrm{Na}$ obra de Calder, sente-se a penetração da natureza pelos meios inanimados. Ela está cheia do mundo não-humano - animais das primeiras eras geológicas ou nos limites biológicos: insetos, plantas, algas, protozoários, cogumelos. $\mathrm{E}$ ao lado deles tem o homem o seu lugar no universo, modestamente (não é o lugar central), um e parte da natureza. Calder virou-se assim para o geométrico e o orgânico, para as figuras matemáticas e as formas naturais, para o maquinismo e os vegetais, para os corpos celestes e os bichos da terra, para a natureza e a ciência, isto é, o universo e o homem prolongado pela técnica, e armado de todas as suas atividades. Nesta última qualidade, a máquina também entrou no seu mundo com as demais coisas do universo, plantas, bichos, cristais, astros, micróbios, caramujos. Desta maneira, pôs ele fim a esta escultura batida, desacreditada e vazia de apoteose vã, e de alegorias mortas.

A escultura de Calder extravasa do campo das atividades específicas do tradicionalismo escultural. Pondo de lado as crônicas preocupações de volume, de modelagem, de superfície, só guardou da velha arte acadêmica, e nisso revela um traço característico de modernismo, o interesse pelas possibilidades do material. Suas pesquisas nesse sentido são notáveis. Ninguém o iguala, por exemplo, na profundeza com que 
sabe seguir, até as nuanças, as insinuações da madeira. E o que pode fazer do arame é insuperável. Não foi por outra razão que Paris cognominou-o le roi du fil de fer. Sua intuição maravilhosa do material em parte alguma se revela com maior esplendor do que nesse admirável Monstro de maçã que soube tirar da madeira como que movido apenas por um senso divinatório, ou uma faculdade misteriosa de comunicação íntima com as coisas, as mãos desprovidas de quaisquer ferramentas, como as de um mágico ou de um parteiro feliz. Desimpedido o seu caminho de todos os estorvos acadêmicos, ele toma por uma trilha nova que, pouco a pouco, o leva cada vez mais longe da estatuária ultradecadente com Rodin, ou mesmo da que saiu fisicamente regenerada das mãos possantes de Maillol.

Inspirando-se na abstração e na arte desinteressada de pintores como Mondrian, Léger e Miró, abandona seus antigos brinquedos articulados e esculturas em arame. Inicia então em Paris, por volta de 1931, uma arte nova, pura e severa, a que define com frio rigor científico como "esquemas vetoriais", os quais foram depois batizados sonoramente por outro pintor, Pascin, de estábiles. Apesar de consistir então em pura geometria no espaço, em que dominam linhas rígidas de arame, a organização plástica dessas coisas novas é de maior densidade do que tudo o que já fizera até então, excluídas algumas de suas admiráveis figuras em madeira de épocas anteriores. Agora, na confecção desses vetores combina outros materiais ao arame, e alcança uma flexibilidade que o próprio arame em si nunca pôde dar. Graças a tal fluidez, seus objetos ganham em latitude plástica, criando relações mais pesadas de universalidade, libertos de quaisquer limitações contingentes ou unilaterais.

As suas composições e objetos abstratos não dotados da faculdade de mover-se, seus estábiles, são peças de arame ou de aço, fixas, armadas sob uma forma total, feita de padrões parciais, que nada representam de objetivo. Por vezes, sua força sugestiva é maior que a dos móbiles, e muitos evocam idéias de formas animais.

Nos estábiles procurou Calder atingir a relação ideal do objeto no universo; isto é, da coisa abstrata, que não se parece a nenhuma outra de existência natural, que ele criou - e para a qual teve de encontrar no espaço o seu lugar próprio, único, e fixá-lo aí para a eternidade. Assim, o que o atrai nesta categoria estática de objetos é o que ele mesmo chamou de "um sentido de relação cósmica".

Pelo novo atalho por onde se embrenhou, já Gabo se havia lançado antes dele, quando introduziu, pela primeira vez na escultura, o movimento real e não mentalmente representado. Calder, porém, não se contentou com um só movimento, logo tornando mais complexa a contribuição desse novo fator. De fato, ao introduzir na

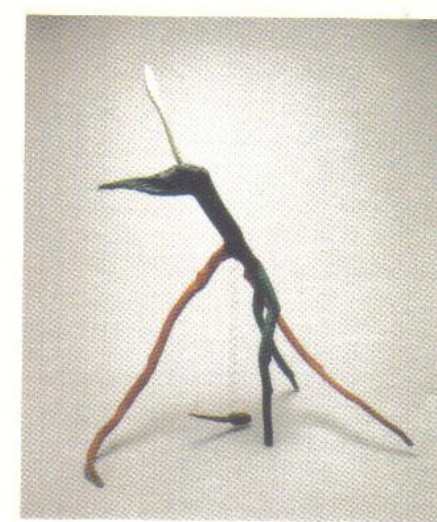

O monstro da maçã, 1938. 
estrutura do objeto o movimento real, ele a enriquece extraordinariamente, a despeito da pobreza em qualidades propriamente esculturais do material em que trabalha — arame, vidro, aço etc.

Para ele, os novos objetos, chamados de móbiles por Marcel Duchamp, não passam de "formas plásticas em movimento". Mas este não é um simples movimento de translação ou rotação, e sim de diferentes tipos, velocidades e amplitudes, que, reunidos, combinados ou compostos, dão uma resultante total. E ele explica: assim como se pode compor cores, ou formas, assim também se pode compor móbiles...

Esses móbiles, ainda que em estado de repouso, são em si, realmente, composições perfeitas. Ao serem atuados, evoluem no espaço, enchendo-o de sugestões, que dão ao objeto estranho poder de fascinação.

Com um sopro podemos tanger um móbile, cujos braços ou pétalas ou bolas se agitam e desenham no ar uma sucessão de formas imprevistas que se vão convertendo, umas após outras, em vertigem caleidoscópica, de pássaro e flor, de peixe em cometa, de árvore em bicho, e assim por diante.

Calder parte assim em busca do gesto rítmico, puro e nu, que está por trás da representação linear do desenho e é por assim dizer o impulso inicial, a mola de todo esforço de expressão gráfica. Atinge com isso o âmago da experiência plástica, nessa espécie de caça ao gesto cinético, o qual, afinal, consegue nos revelar, como se fora o impulso aristotélico do primeiro motor, o ponto de onde se inicia e toma vida todo objeto no mundo. $\mathrm{O}$ impulso subjetivo que leva o artista a exprimir-se plasticamente permanece ativo e dinâmico, através do movimento, no próprio objeto criado. Esta incorporação tem para Calder um "valor de contraponto" que vem adornar o conceito plástico de uma qualidade de pura coreografia abstrata. O gesto, embora apenas estado mental, precede e não se aparta da obra de criação realizada. Seu objeto adquire uma ressonância de instrumento - que dança, ou vibra, ao ser tocado.

Os movimentos variados dos móbiles, uns se desenvolvem numa sucessão de escalas, outros se equilibram delicadamente; outros são animados pela ação da gravidade; outros tendem, ao contrário, a elevar-se, como balões cativos; outros se agitam ao léu das correntes de ar, como os cata-ventos, enquanto finalmente outros evolvem por meio de uma corrente elétrica. Calder combinou, nesses móbiles, o espaço ativo com o tempo também ativo.

O móbile de Calder é em geral suspenso de um ponto fixo, e o movimento se desenvolve dentro do sistema fechado que assim se cria. Se a amplitude e as diferenças de velocidade dos movimentos dentro do sistema parecem tirar o plano de conjunto ao 
objeto, descoordenando-o pela multiplicidade caótica de posições, a desordem no fundo obedece a uma sucessão no tempo. Apoiando-se todo o sistema num ponto fixo, as suas partes, a descreverem suas órbitas ou seus movimentos diferentes, pendular, circular ou elíptico, podem retardar-se pelo caminho mas tendem a fechar o ciclo, voltando ao ponto de partida, o objeto em repouso. Dessa forma, o movimento não é arbitrário, e se sucedeu num traçado formal predeterminado.

Com a captação do movimento nas suas construções, Calder lança a ponte ideal suspensa, que vem ligar as artes do espaço às de sucessão no tempo. Sem que se mova, a estátua apresenta-se ao observador como se girasse em torno de si mesma, em círculo. A música, no entanto, que escorre no tempo, não gira em círculo, mas é antes como um rio que passa. Nas experiências de movimento em Calder há um esforço de superação das duas artes.

Isso traz para as suas construções conseqüências imprevisíveis. Este novo fator estrutural que assim introduz poderia chamar-se, sem abuso talvez, de quarta dimensão: o fator tempo, estreita e realmente ligado a uma função especial, a geração de uma forma nova, total mas aberta, dum objeto no espaço. O espaço-tempo em função da criação plástica. Daí lhe advém essa vitalidade rítmica que é o segredo, a alma dos objetos de Calder.

Energias postas numa relação rítmica, eis a fórmula de seus móbiles.

Cedo sua experiência distinguiu nos móbiles duas formas de movimento: o produzido por manivelas ou motor, ligado ao objeto, e o produzido livremente por qualquer impulso fortuito; os objetos assim movidos são naturalmente baloiçantes, suspensos, pendentes de arame e até de cordão.

Seu primeiro móbile de movimento mecânico era impulsionado por uma manivela presa pelo lado de fora de uma caixinha de arame, que fazia mover um peixe também de arame. Daí nasceu naturalmente a idéia de substituir a manivela por uma corrente elétrica ou um motor. Era a transição natural de uma máquina simples a uma composta ou complexa. Em vez de manícula do lado de fora, para fazer um simples movimento de vaivém, ele coloca um motor para acionar todo um complexo organismo enquadrado num painel de cores elementares, dentro do qual giram ou evoluem figuras geométricas, a um ritmo disciplinado pelas engrenagens.

Os móbiles a movimentos livres, com suas pétalas e folhas, fios ou hastes, rodas ou esferas, numa forma em repouso idealmente recortada no ar, são inteiramente entregues ao acaso. É para este que apelam as figuras geométricas ou vivas e naturais que se geram no espaço. Ao saírem do estado de repouso, bailam no ar, ou traçam ou expelem 


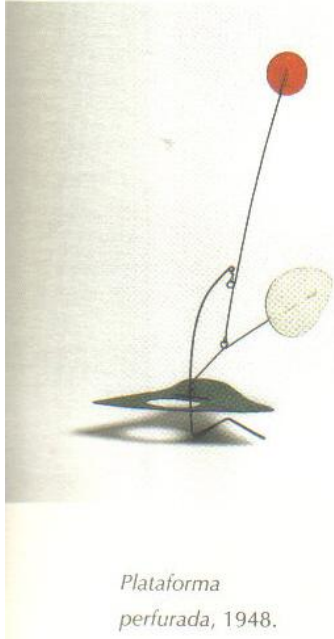

perfurada, 1948 . rosas de fogo de artifício, embriões de seres desconhecidos, sugestões de bichos, de pássaros, de coisas que viviam apenas nas virtualidades espaciais.

Não é, porém, a mera percepção visual de um objeto em repouso ou em movimento que o inspira; é a imaginação plástica. Nesses móbiles, tangidos a vento, o que precisamente ele deixa ser completado pela imaginação, ou o acaso, é a idéia da forma total inteiramente desabrochada. Ele não copia, nem traslada movimentos, nem detalhes de objetos ou figuras reais, nem suas partes como na sucessão de quadros dum filme cinematográfico. A concepção plástica total pode ficar em estado latente (quando os objetos estão em repouso); mas no processo de fazê-la desenrolar-se dentro do âmbito do grande contorno externo ele vai além da simples representação do movimento em pintura ou escultura, a qual fica no domínio puramente mental. Deixa assim que o acaso venha dar impulso à imaginação...

Nos seus painéis motorizados, todavia, se não há lugar para um papel mais altivo da imaginação, há contudo um círculo que se fecha e refecha constantemente. O movimento se desenrola, as figuras geram-se no espaço, e o espaço como que as exaure, as esvazia, voltando elas, por uma fatalidade cíclica, ao nada, isto é, à posição inicial do repouso - e o ciclo recomeça.

É a idéia circular mesma que faz com que o movimento mecânico, pela repetição e a translação, detalhada, parte por parte, dos volumes e massas em ação, nos apresente uma concepção formal total e não uma espécie de fotografia ou reprodução fiel de coisas em movimento natural. Compare-se aqui a mecânica do mar que, se é monótona na sua repetição, espicaça-nos sempre a imaginação como algo de eternamente novo.

O movimento motorizado dos painéis tem, na sua precisão, o ritmo ć́clico das leis que regem o movimento das esferas. É a rota dos astros através dos espaços infinitos. Os seus móbiles se originaram, aliás, de associações cósmicas. Já a seu primeiro móbile Calder chamou de Relação terrestrial: dois círculos em arame a projetarem uma esfera seccionada em diagonal. A mesma idéia se repete, apenas mais complexa e realizada, em seu Universo.

O tom monótono pela repetição dos movimentos nesses painéis tem a fatalidade fascinante da atração dos corpos celestes e a alegria que jaz latente na concepção das voltas periódicas previstas nos cálculos do sábio ou na especulação dos filósofos. A ânsia dos seus movimentos espiralóides tem qualquer coisa que nos faz esperar o desvendar do segredo das coisas. O esforço ascendente dessas formas lembra-nos o arrojo gótico na sua sôfrega e romântica aspiração para as alturas, aquelas figuras geométricas se elevam em vagas como o mar, o amor ou a música, para se despedaçarem dos ápices 
supremos, subitamente exaustas. A esfera cai do alto de sua mola retorcida e balançase no espaço, dramática e silenciosamente, ao apelo invisível da gravidade. Cones e prismas por si mesmos adquirem drama. A geometria volatiliza-se em bailados.

Calder descobre a relação entre o perene e o fortuito, e desvenda o que a imaginação pode dever à mecânica, quando compensa o ritmo padronizado dos objetos movidos a manivela ou motor por ritmos livres. Ultrapassa assim as limitações do construtivismo e entra pelo mundo das formas orgânicas. A liberdade rítmica resultante intensifica-se, e o inacabado de suas obras de juventude como os bonecos do circo readquire agora imprevista profundeza de sugestão. O jogo de sombras de seus móbiles suspensos projeta-se com um encanto enigmático.

Ao se entregarem aos ritmos livres, as suas composições ganharam em sugestões de volumes, inflando-se nos seus móbiles baloiçantes ou recortando no ar gestos intumescidos de plasticidade. As imagens virtuais que nos sugerem esses móbiles gesticulantes atingem uma transparência muito mais voluptuosa e plástica, e mais profunda e menos anedótica do que o volume vazio das antigas cabeças e figuras em arame. Os móbiles suspensos alcançam uma virtualidade quase absoluta, abertos a todas as combinações possíveis nas suas relações espaciais. De repente é uma aranha que se dissolve num monstro ou numa reverberação de estrelas, em metamorfoses que se sucedem sem interrup̧̧ão sob a vara mágica do acaso.

Por sua vez, as antigas esculturas estáticas, que se realizavam antes num plano simples, complicam-se agora nos últimos grandes estábiles em objetos de densa organização estrutural, assumindo enorme poder de fascinação.

Ultimamente, premido talvez pelas dificuldades surgidas com a guerra de encontrar material para seus grandes monstros estáticos de aço, inventou Calder uma nova categoria de estábiles a que chamou de constelações. São peças em madeira descarnada, sem pintura, de formas geralmente radiais, ou estelares, que se prendem umas às outras por fios grossos, rígidos, de ferro, e de tal modo a poder apoiar-se sobre uma parede, no chão, sem base ou pedestal especial. Ao prenderem-se ao muro, como que aderem ao mesmo, numa estranha sugestão de parasita, ou de caramujo ou ostra. Algumas têm a rispidez dum cacto. Outras, de estrutura já mais ambiciosa, de dimensões maiores, apóiam-se no solo, de onde desabrocham com um ímpeto de raios que se congelam no espaço. Apontam bruscamente em direções que se opõem, num estonteamento de gestos que desconcertam embora carregados de mudas apreensões.

Não é a impressão passageira, "um instante momentâneo" (sua própria expressão), que Calder capta com os seus objetos; com eles, procura realizar, ou encontrar - 
disse-o definindo sua própria concepção artística - "uma lei física de variação entre os acontecimentos da vida" (e a isto chama de "abstrações que a nada se parecem na vida, a não ser na sua própria maneira de reagir").

O movimento neles não visa à impressão de um instante; visa, ao contrário, ao que há de mais eterno, perene, imutável no conceito do dinâmico, isto é, sua perpétua e ilimitada virtualidade, e que se manifesta paradoxalmente sobretudo no repouso. $\mathrm{O}$ repouso contém potencialmente todas as formas ideais, desencarnadas de qualquer convenção ou representação. Se a forma é a fonte irredutível de toda idéia cinética, o movimento é o princípio latente da forma; é a origem geradora de toda forma. Os objetos calderianos são construídos para permitir todas as variações possíveis da forma.

A unidade visual e espacial se revela pela trama e contorno de linhas ou planos externos e a força, convincente e funcional, dos materiais utilizados. O que mantém o grupo artístico coeso e unido é o poder de afirmação dessa unidade total em forte contraste com o espaço circundante.

O bracejamento de seus móbiles não significa apelos de desespero, ou gestos incoerentes e isolados, mas evoluções que se ordenam, a despeito da aparência, dentro dum todo espacial. É do desenrolar pleno do movimento de todos os braços (espinhos, galhos, hastes, talos, fios etc.), em todas as variantes possíveis, que brota a imagem completa da forma enfim revelada. É só quando os movimentos das partes se realizam por inteiro que se delineiam, perfeitamente acabados, os contornos do objeto na sua forma integral e última. É este um instante fugaz e luminoso de integração com a realidade cósmica. Assim, a unidade espacial do objeto se concretiza, e a legitimidade plástica da obra se manifesta em toda a sua claridade silenciosa e surpreendente.

A oposição dialética que tempera seus objetos, móbiles e estábiles, é sobretudo dada pelo jogo antitético da tensão e da coesão, do equilíbrio e da assimetria, do estático e do dinâmico. Em certos móbiles sente-se a tensão através dum estado de equilíbrio patético, quando o objeto está em repouso, e suas partes são de um individualismo quase sectário; e alternadamente, uma coesão totalitária, quando o mesmo está em movimento.

Nos móbiles a ritmo livre, a coesão, o que a dá é o movimento mesmo. Em seus grandes estábiles, porém, sente-se a presença de duas forças hostis, em face uma da outra - a tensão e o espaço circundante. $\mathrm{O}$ mesmo se passa com as constelações.

Nos móbiles não motorizados há um enfraquecimento da coesão em proveito da maior flexibilidade, variação de padrões, espontaneidade do inacabado; nos estábiles, há maior coesão, menos variação, mas o cuidado maior da precisão estrutural. Aos mate- 
riais dos móbiles de ritmo livre faltam a autoridade e peso plástico dos materiais dos grandes estábiles. Sendo mais flexíveis, porém, têm a sedução do inacabado. É a autoridade do metal pesado, do aço, em face da liberdade do cordão mambembe e do caco de vidro vagabundo. $\mathrm{Na}$ ausência de coesão interior, ganham esses móbiles a movimento livre em improvisação, em sugestibilidade - elementos necessários à captura da plenitude da forma no espaço absoluto,

Nos estábiles, a força de coesão total interna que irradia do centro vital é tremenda; do contrário não poderia vencer a extraordinária tensão das partes, dos detalhes das linhas de contorno, nem o sedutor convite à dispersão. Aqui, a dispersão e a tensão se conciliam por fim, após um combate de cujo calor o ar ainda como que se sente impregnado.

A coesão em Calder não é, porém, de qualidade orgânica ou funcional. Ela não vem da convergência de todas as partes para alcançar um fim comum, exterior à natureza intrínseca, desinteressada do objeto. A coesão de seus painéis não é funcional porque nada se visa, em função direta das partes, que nada pretendem representar. A coesão aqui é dada, entre outros elementos, pelo próprio retângulo do painel ou pelo plano de fundo, em frente ao qual se movem as partes.

A oposição necessária entre tendências opostas, como gravidade e ímpeto expansionista, essa fascinação cósmica pelas relações distantes e díspares entre objetos que se movem livremente no espaço, e a necessidade pungente de conteúdo, de substância plástica formal, que extravasa de cada coisa, de cada pensamento criador de Calder, vêm também da tensão de forças, de linhas e planos, e não da massa ponderável. Mesmo nos grandes estábiles de estrutura mais pesada, a oposição surge seja da tensão dos ângulos, das linhas (de forças, pois) e do centro vital, seja da força centrífuga da massa solar do objeto, ou da antítese tensão-gravitação; nunca de massa contra massa.

No estábile que chamou de Gibraltar, por exemplo, ao lado de contrastes locais entre os diferentes tratamentos da matéria (madeira polida - madeira tosca etc.), a oposição à gravitação é evidente entre a esfera e o plano inclinado de massa; entre a esfera e a massa; como é visível também em outros objetos a resistência à gravitação que vem de outras formas geométricas (cilindros, cones, esferas) e o impulso mecânico, ascendente, que lhe impele os volumes num movimento espiralóide para o alto.

Calder nunca se esquece, como bom engenheiro, de submeter os seus objetos móveis a precisas equações de peso e equilíbrio. Em muitos pintores abstratos, poetas tangidos ao açoite da inspiração, aos golpes de vento do inconsciente, como Paul Klee, estas forças que desencadeiam, como maus espíritos, acabam escapando ao controle do artista. Não neste sonhador de olhos abertos que apesar das aparências arielescas sabe 
coordenar as imagens etéreas sob precisos cálculos matemáticos. Um dos seus segredos é precisamente o uso que faz do material da indústria moderna em que o elemento funcional, utilitário, é decisivo, mas dando-lhe um direito inesperado à fantasia, um direito ao casamento intempestivo com a imaginação.

Com esses materiais industriais não ficou Calder, entretanto, escravo do funcional; ao tratá-los, o impulso da própria fantasia lhes desviou o curso, lhes torceu as formas e com estas o destino utilitário e convencional. Ele sabe, para realce da dramaticidade plástica, como violentar a própria funcionalidade do material. Fez assim da mecânica um sistema a serviço de nada, trabalhando ao deus-dará, para o sonho e a especulação - para não mover coisa alguma, para não ganhar dinheiro.

A idéia das formas dinâmicas aflorou em Calder como idéia de engenheiro. Não procurava ele qualquer representação simbólica da ação, mas o conceito puro, abstrato da forma. Antes de reintroduzir as formas orgânicas, redescobertas em Miró, havia ele abordado o problema do cinetismo formal, empenhado em encontrar as relações de dois ou mais objetos no espaço. Por isso mesmo, evitou a princípio qualquer forma natural ou orgânica, precisamente para ganhar em intensidade na abstração criadora, e para não tornar a incorporação do movimento em expediente anedótico, um mero desenrolar de pantomimas com marionetes, ou imagens representativas de seres orgânicos reais.

Mas quando pode, sem receio de desviar a atenção do espectador da finalidade desinteressada e plástica visada, reintroduzir as formas orgânicas na sua obra, uma nova personagem vem habitar seus objetos: o humor, o humor que reaparece de tornaviagem, da saudosa época do circo e das caras de arame.

Fugindo ao real imediato - abstracionista que nunca perdeu o sorriso - , Calder passa a tirar do ritmo de azar ou do ritmo mecanizado formas que por vezes nos podem sugerir figuras ou motivos concretos do mundo dos seres vivos. É que seu abstracionismo, sem caráter doutrinário mas antes poético, concreto, no sentido experimental, é filho de um permanente encantamento pelo mundo, de um estado de graça perene que espera a cada hora a reabilitação de todas as virtualidades sublimes e radiosas que se possam esconder no universo.

Não se encontram tampouco na sua obra gestos, linhas ou planos significando funções ou símbolos convencionais (como, por exemplo, um braço estendido), com o fito de nos dar mentalmente a idéia da ação. Há, sim, mas são formas espaciais e plásticas, há contornos e silhuetas claramente definidos, e movimentos puros, reais, em estado de repouso ou não. A arte de Calder só conhece uma funcionalidade - a do próprio mate- 
rial em que trabalha, a que é vital, inerente à matéria. E mais nenhuma outra externa ou estranha à intrínseca propriedade desta. Mesmo quando cria coisas, objetos por assim dizer com fins práticos, externos, o fim utilitário da obra se funde na perfeição e elegância com que ele o integra e submerge no poder de sugestão peculiar ao material de que é feito o objeto. É, pois, da pura gratuidade de movimento e da abstração de suas formas que nasce a sua força sugestiva, aquela imagem do equilíbrio cósmico com que nos encanta ou nos intriga.

Mas este fervoroso adepto do construtivismo abstracionista, que desrespeitou gêneros e modos tanto na escultura como na pintura, que alia o purismo mais inequívoco à poesia quase subjetiva do surrealismo, que desprezou, enfim, os materiais convencionais de ambas as artes — que é ele? Um pintor? Um escultor? É um artista-mecânico, um construtor-criador desinteressado, um engenheiro de arte; calculista e planejador do não-imediato e da fantasia.

A exploração dessa espécie de automatismo dinâmico que são os seus móbiles de vento deve-se em parte à experiência da arte "automatista" de Miró e Arp. A introdução do acaso, do fortuito vem talvez de um eco longínquo de Dadá. Em Calder, há sempre um elemento de zombaria, de desrespeito pelos cânones vetustos, pelo academismo... passadista ou modernista, desrespeito que lembra Dadá. Um Dadá alegre e otimista: é um paradoxo que só um americano poderia aplacar.

Mas não haverá aqui também influência surrealista? Na verdade, esse elemento fortuito é um dos fatores essenciais da inspiração surrealista. O movimento livre que apela para o azar, à mercê de um sopro intempestivo, de uma lufada inopinada como as reviravoltas do destino, tem alguma coisa do automatismo, que lhe vem provavelmente de Miró, treinado em invocar os feitiços e poderes desse demônio.

O automatismo dos móbiles de vento não é subjetivo, já se vê; não é psíquico; mas vem de um abandono total à aventura externa da natureza, ou do impulso inicial do observador. Passa-se aqui ainda alguma coisa como um fenômeno musical que depende de vários fatores externos, objetivos e subjetivos, para que se possam desenvolver no tempo as suas magníficas e inexploradas sonoridades. Não só na introdução do fator tempo, como na necessidade de contar com o fator acaso (disposição subjetiva ou acidente natural externo, ventos ou calmaria, equilíbrio estático ou tensão de dramática vitalidade) esta arte atinge ao estado puro da música por que tanto almejam os puristas e transcendentalistas do não-objetivo e da abstração criadora.

Se a arquitetura é "música congelada", como já se tem dito, os móbiles calderianos são "músicas visuais", para sempre inexecutáveis. Só para "ler". A translaçâo no espaço 
de suas formas, evocando a derrota dos corpos celestes, empolga e fascina, como a música silenciosa das esferas. Casando a vida e a abstração, conjugando o humor à mecânica, ele navega entre as duas grandes alas da arte moderna: o surrealismo, com o seu romantismo incurável que degenera às vezes em charada anedótica, e o abstracionismo cuja obsessão de purismo formal se resolve não raro entre uma espécie de misticismo branco e a pura puerilidade.

Nesse mundo inédito, que é a criação calderiana, dá-se uma desaclimatação total.

[Ensaio escrito em Nova York, em 1944, e publicado originalmente in Arte, necessidade vital. Rio de Janeiro: Casa do Estudante do Brasil, 1949, pp. 108-129. Em 1948, serviu de base para a conferência "Calder e a música dos ritmos visuais", pronunciada no Ministério da Educação e Saúde, no Rio de Janeiro, e no Museu de Arte de São Paulo; recolhido in Pedrosa, Modernidade cá e lá, op. cit., pp. 67-79.] 
A dissertação visa alçar uma reflexão sobre a produção e contribuiçào crítica de Mário Pedrosa para a arte brasileira, como também identificar alguns de seus paradigmas artísticos que colaboraram para a consolidaçào de um arcabouço teórico para História da Arte Moderna, tanto no plano nacional, quanto internacional. objetiva-se delinear a relaçào entre o que Pedrosa absorveu sobre as teorias gestálticas e exemplos de como ele as aplicou na tessitura de seu discurso crítico. Ao sedimentar o foco de análise no envolvimento do crítico brasileiro com o tema da psicologia da forma, propóe-se ressaltar as implicações estéticas de seu estudo pioneiro $D O$ Natureza Afetiva da forma no Obra de Arte. Pretendeu-se, ainda, identificar a intersecção entre a psicologia da forma e a crítica de arte de Mário Pedrosa, propondo a influência destas teorias nos textos sobre a obra do artista americano Alexander Calder, artista considerado pelo crítico, como o emblema da estética abstrata construtiva. Buscou-se verificar como as teses da psicologia da forma ofereceram ao crítico, subsidios conceituais para uma nova relação com as premissas constitutivas e cognitivas da estética abstrata. 